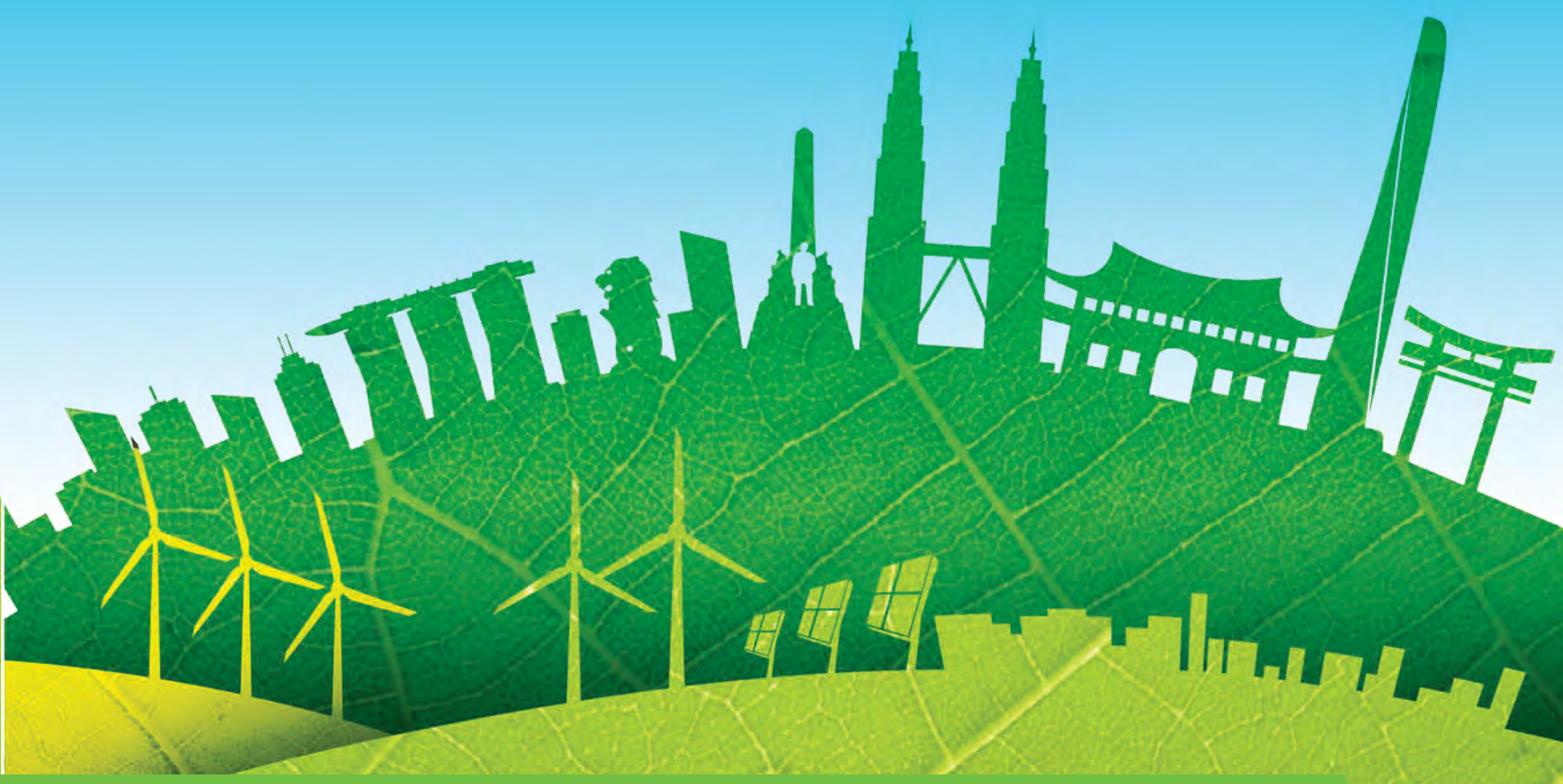

Promoting Green

Local Currency Bonds

for Infrastructure

\title{
Development in ASEAN+3
}

APRIL 2018 
Promoting Green

Local Currency Bonds

for Infrastructure

Development in ASEAN+3

APRIL 2018 
(C) 2018 Asian Development Bank

6 ADB Avenue, Mandaluyong City, 1550 Metro Manila, Philippines

Tel +632 632 4444; Fax +6326362444

www.adb.org

Some rights reserved. Published in 2018.

ISBN 978-92-9261-112-5 (print), 978-92-9261-113-2 (electronic)

Publication Stock No. TCS189249-2

DOI: http://dx.doi.org/10.22617/TCS189249-2

The views expressed in this publication are those of the authors and do not necessarily reflect the views and policies of the Asian Development Bank (ADB) or its Board of Governors or the governments they represent.

ADB does not guarantee the accuracy of the data included in this publication and accepts no responsibility for any consequence of their use. The mention of specific companies or products of manufacturers does not imply that they are endorsed or recommended by $\mathrm{ADB}$ in preference to others of a similar nature that are not mentioned.

By making any designation of or reference to a particular territory or geographic area, or by using the term "country" in this document, $A D B$ does not intend to make any judgments as to the legal or other status of any territory or area.

This work is available under the Creative Commons Attribution 3.0 IGO license (CC BY 3.0 IGO)

https://creativecommons.org/licenses/by/3.0/igo/. By using the content of this publication, you agree to be bound by the terms of this license. For attribution, translations, adaptations, and permissions, please read the provisions and terms of use at https://www.adb.org/terms-use\#openaccess.

This CC license does not apply to non-ADB copyright materials in this publication. If the material is attributed to another source, please contact the copyright owner or publisher of that source for permission to reproduce it. $\mathrm{ADB}$ cannot be held liable for any claims that arise as a result of your use of the material.

Please contact pubsmarketing@adb.org if you have questions or comments with respect to content, or if you wish to obtain copyright permission for your intended use that does not fall within these terms, or for permission to use the ADB logo.

Notes:

In this publication, “\$” refers to United States dollars, unless otherwise stated.

ADB recognizes "Brunei” as Brunei Darussalam; "China” as the People's Republic of China; "Hong Kong” as

Hong Kong, China; "Korea" as the Republic of Korea; "Lao" as the Lao People's Democratic Republic; "America” as the United States; "Vietnam" as Viet Nam; and "Hanoi" as Ha Noi.

Corrigenda to ADB publications may be found at http://www.adb.org/publications/corrigenda. 


\section{Contents}

Tables, Figures, and Boxes

I. Introduction 1

A. What Are Green Bonds? 2

B. Global Green Bond Markets 2

C. What Is Driving the Growth of Green Bond Markets? 8

D. Barriers to Green Bond Markets 9

E. Objectives 11

II. Green Bonds-A Primer 12

$\begin{array}{ll}\text { A. Background } & 12\end{array}$

B. Why Issue Green Bonds?

C. Policy Framework for Green Bonds $\quad 15$

D. Types of Green Bonds 25

E. Issuers of Green Bonds $\quad 29$

F. Issuing a Green Bond $\quad 33$

G. Cost of Issuing a Green Bond $\quad 35$

H. External Reviewers 40

I. Investors in Green Bonds 44

J. Green Bond Indices $\quad 50$

K. Securities Exchange Listings $\quad 54$

III. Policy Options for Promoting Local Currency Green Bonds 57

A. Preconditions for Local Currency Green Bond Markets 58

B. Available Green Financing Opportunities 63

C. Policy Framework for Green Bonds 66

D. Expanding the Supply of Green Bonds $\quad 71$

E. Facilitating Demand for Green Bonds $\quad 78$

F. Market Development Initiatives $\quad 85$

G. Regional Initiatives $\quad 89$

H. Summary and Conclusion $\quad 94$

\section{Appendixes}

1 Country Background Notes $\quad 97$

2 Profiles of Green Bond Funds 132 


\section{Tables, Figures, and Boxes}

\section{Tables}

1 Green Bond Databases 3

2 Top 10 Financial Corporate Green Bond Issuers 7

3 Top 10 Nonfinancial Corporate Green Bond Issuers 7

4 Barriers to the Development of Green Bond Markets 10

5 Climate Bonds Initiative-Climate Bonds Taxonomy 19

6 Green Bond Principles and National Green Bond Guidelines 22

7 Bond Market Regulators and Green Bond Guidance in the People's Republic of China

8 Government Agency Green Bond Issues in ASEAN+3 31

9 Selected Recent Financial Green Bond Issuance 32

10 Green Bond Framework 34

11 Incremental Cost of Green Bond Issuance 36

12 Annual Incremental Cost of Green Bonds 37

13 Summary of Studies on Green Bond Pricing 39

14 External Reviews of Green Bonds in $2016 \quad 41$

15 External Reviews of People's Republic of China Green Bonds in 2016

16 Major Second Opinion Firms 43

17 Green Bond Funds 49

18 Global Green Bond Indices 51

19 Inclusion Criteria for Green Bond Indices 52

20 ChinaBond Green Bond Index Series 53

21 CUFE-CNI Green Bond Index Series 54

22 Overview of Key Stock Exchanges with Green Bond Listings 56

A1.1 Brunei Darussalam Financial and Capital Market Overview, $2016 \quad 98$

A1.2 Cambodia Financial and Capital Markets Overview, 2016

A1.3 The People's Republic of China Financial and Capital Markets Overview, 2016100

A1.4 Indonesia Financial and Capital Markets Overview, 2016

A1.5 Japan Financial and Capital Markets Overview, $2016 \quad 108$

A1.6 Green Bond Issues in Japan 110

A1.7 Republic of Korea Financial and Capital Markets Overview, $2016 \quad 112$

$\begin{array}{lll}\text { A1.8 Republic of Korea Green Bond Issues } & 113\end{array}$

A1.9 Lao People's Democratic Republic Financial and Capital Markets Overview, 2016

$\begin{array}{ll}\text { A1.10 Malaysia Financial and Capital Markets Overview, } 2016 & 115\end{array}$

A1.11 Myanmar Financial and Capital Markets Overview, $2016 \quad 119$

$\begin{array}{ll}\text { A1.12 The Philippines Financial and Capital Markets, } 2016 & 120\end{array}$

A1.13 Singapore Financial and Capital Markets Overview, 2016 
$\begin{array}{ll}\text { A1.14 Singapore Green Bond Issues } & 126\end{array}$

A1.15 Thailand Financial and Capital Markets Overview, $2016 \quad 127$

A1.16 Viet Nam Financial and Capital Markets Overview, 2016

\section{Figures}

1 Green Bond Issues by Year, Two Leading Data Sources 3

2 Labeled and Pure Play Green Bond Issues 3

3 Green Bonds by Currency of Issue, cumulative from 1 January 2007

to 30 June 2017

$4 \quad$ Green Bonds by Country of Issue, cumulative from 1 January 2007 to 30 June 2017

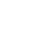

5

$5 \quad$ Green Bonds by Type of Issuer, January-June $2017 \quad 6$

6 Green Bonds by Country, January-June $2017 \quad 6$

7 Green Subsets of Responsible Investments $\quad 13$

$\begin{array}{ll}\text { A1.1 Local Currency Bonds Outstanding } & 101\end{array}$

$\begin{array}{ll}\text { A1.2 Local Currency Bonds Outstanding } & 101\end{array}$

$\begin{array}{ll}\text { A1.3 Local Currency Bonds Outstanding } & 106\end{array}$

$\begin{array}{lll}\text { A1.4 Local Currency Bonds Outstanding } & 106\end{array}$

$\begin{array}{ll}\text { A1.5 Local Currency Bonds Outstanding } & 109\end{array}$

$\begin{array}{lll}\text { A1.6 Local Currency Bonds Outstanding } & 109\end{array}$

A1.7 Local Currency Bonds Outstanding 112

A1.8 Local Currency Bonds Outstanding 112

A1.9 Local Currency Bonds Outstanding 116

$\begin{array}{ll}\text { A1.10 Local Currency Bonds Outstanding } & 116\end{array}$

$\begin{array}{ll}\text { A1.11 Local Currency Bonds Outstanding } & 121\end{array}$

$\begin{array}{ll}\text { A1.12 Local Currency Bonds Outstanding } & 121\end{array}$

$\begin{array}{ll}\text { A1.13 Local Currency Bonds Outstanding } & 124\end{array}$

$\begin{array}{ll}\text { A1.14 Local Currency Bonds Outstanding } & 124\end{array}$

$\begin{array}{ll}\text { A1.15 Local Currency Bonds Outstanding } & 128\end{array}$

$\begin{array}{ll}\text { A1.16 Local Currency Bonds Outstanding } & 128\end{array}$

A1.17 Local Currency Bonds Outstanding 131

A1.18 Local Currency Bonds Outstanding 131

\section{Boxes}

$1 \quad$ Examples of Green Bond Issuers and Bond Types 29

2 Project Financing and Project Bonds 62

3 Is That Bond Green? 


\section{Foreword}

The Asian Development Bank (ADB) is working closely with the Association of

Southeast Asian Nations (ASEAN) and the People's Republic of China (PRC), Japan, and the Republic of Korea-collectively known as ASEAN+3-to develop local currency bond markets and facilitate regional bond market integration under the Asian Bond Markets Initiative (ABMI). ABMI was launched in 2002 to strengthen the resilience of the region's financial system by developing local currency bond markets as an alternative source to foreign-currency-denominated, short-term bank loans for long-term investment financing.

This study was undertaken under ABMI with generous financial support by the Government of the PRC. Building on the study to promote the use of local currency bonds for infrastructure finance, ASEAN +3 policy makers are exploring options to promote green local currency-denominated bonds to meet the region's infrastructure development needs.

Financing infrastructure projects with green local currency-denominated bonds is highly desirable for the following two reasons. First, financing infrastructure projects with long-term local currency bonds instead of short-term bank loans denominated in foreign currency would make the projects less vulnerable to currency and refinancing risks, especially as they generate revenue in the local currency. Without costly hedging, which may not be available for longer-dated tenors in all currencies, an exchange rate depreciation can increase debt service requirements relative to local currency revenue, potentially threatening the viability of a project. Second, ASEAN+3 has a significantly large demand for infrastructure but is exposed to a range of climate conditions and extreme events. Because of this, green bonds supported within the framework of ASEAN +3 would not only help meet the long-term financing of the region, but could become an effective investment tool to finance its transition to a low-carbon region.

The study was prepared by A. Michael Andrews and Brent Sutton, under the direction of A. Noy Siackhachanh, senior advisor, Economic Research and Regional Cooperation Department (ERCD). Additional guidance and assistance was provided by Richard D. Supangan, senior economics officer, ERCD. A.N. Siackhachanh and R. Supangan participated in some of the fieldwork for the project. Jürgen Conrad, head, Economics Unit of the ADB Resident Mission in the PRC and Danhui Li and Xuan Rong of the ADB 
Resident Mission participated in some of the fieldwork in the PRC. Margarita Tirona provided research assistance and logistical support. The authors are grateful to the many country officials and market participants who shared their insights and perspectives.

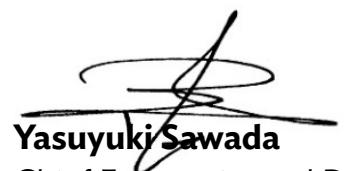

Chief Economist and Director General

Economic Research and Regional Cooperation Department

Asian Development Bank 


\section{Executive Summary}

reen bond markets provide financing that can help support a global transition to a

7 sustainable development path. Green bonds are debt securities whose proceeds are used to finance projects or assets with positive environmental benefits. The defining features of green bonds are: (i) the issuer commits to investing the proceeds in projects or assets meeting explicit eligibility criteria (often called the "green bond framework"); (ii) the proceeds are segregated from other funds available to the issuer; (iii) the issuer provides ongoing reporting on the use of the proceeds and, where possible, the environmental impact of the investments; and (iv) prior to issuance the bond is often evaluated or certified by an independent external reviewer attesting to the veracity of its "green" claim.

Entities issue green bonds to improve their reputation and broaden their investor base. Issuing green bonds demonstrates a commitment to improving the environment. Green bonds are especially attractive to responsible investors who consider both financial and nonfinancial factors in their investment decision-making process. These investors may not have previously purchased an issuer's conventional bonds. Investors buy green bonds to align their portfolios with responsible investment mandates, as well as to earn a competitive rate of return. Governments promote green bond markets to increase the amount of longterm financing available to support national commitments under the Paris Agreement and the United Nation's Sustainable Development Goals.

The first green bond was issued in 2007 and the market has grown rapidly since then. The size of the green bond market was about $\$ 180$ billion in 2017. Estimates vary because data providers use different inclusion criteria. Some unlabeled green bonds are included if the data provider believes the proceeds fund environmentally beneficial projects and some labeled green bonds are excluded if the data provider does not believe the bond is funding projects with a positive environmental impact. Such classification discrepancies are common in financial markets.

\section{A Primer on Green Bonds}

Green bond markets have emerged largely in the absence of a formal public policy framework. Instead, the market has been guided by industry-developed norms and voluntary standards. The most important ones are the Green Bond Principles (GBP) and the Climate Bonds Standard (CBI Standard). In most countries, any issuer can call their bond green, although investors and other stakeholders will only accept them as such if they are issued in accordance with industry norms such as the GBP. As of the middle of 2017, 
only the People's Republic of China (PRC) and India had issued mandatory national green bond standards, though more countries are expected to follow suit.

The GBP are voluntary guidelines on the issuance of green bonds. They are overseen by the International Capital Market Association, an industry group. Compliance with the GBP requires issuers to (i) specify that proceeds will be used for environmentally beneficial projects and assets, (ii) set out a clear process for project evaluation and selection, (iii) keep the proceeds separate from other funds available to the issuer, and (iv) report regularly on the use of the proceeds and the environmental impact of funded projects and assets. The GBP also recommend that issuers obtain an external review to confirm alignment with the principles.

The largest green bond issuers are multilateral development banks and commercial banks. Green bonds have also been issued by national and subnational governments, public agencies, state-owned enterprises, and nonfinancial corporations. The most common type of green bond is a general obligation bond, where the bond is backed by the overall creditworthiness of the issuing entity and not by the green assets it funds. Green bonds have also been structured as project bonds, revenue bonds, asset-backed securities, covered bonds, and sukuk (Islamic bonds).

Issuing green bonds entails higher administrative expenses than comparable conventional bonds. Like a conventional bond, an issuer must determine the size, currency, tenor, coupon, and legal structure of the issue, and comply with appropriate securities regulations. For green bonds, the issuer must also commit staff time to prepare a green bond framework setting out how the proceeds will be invested, manage the allocation of proceeds, and develop an appropriate reporting program. Prior to issuance, the issuer generally, but not necessarily, engages an external reviewer to confirm that the bond is aligned with the GBP or other international or national standards. After issuance, the issuer must provide regular reporting on the use of the proceeds and, increasingly, on the environmental impact of the projects and assets. Depending on the size, tenor, previous experience of the issuer, and extent of post-issuance reporting, the added cost of green bond issuance is between 0.1 and 7.0 basis points. While some issuers have been able to offset this cost by issuing a green bond at a lower yield relative to a conventional bond, the prevailing view among market participants is that there is no systematic difference between the yield on green bonds and comparable conventional bonds.

External reviews take several forms. The most common are second opinions, an assessment by an independent firm with environmental experience as to the credibility of an issuer's green bond framework. Such an assessment provides support for an issuer's claim that proceeds from the bond will fund projects and assets with positive environmental impacts, but they do not provide independent measurement of the expected or actual benefits. The cost of a second opinion is generally between $\$ 15,000$ and $\$ 50,000$, with the actual cost depending on the time to complete the work, scope of engagement, location of issuer, previous work with the issuer, and other business the external reviewer has with the issuer. Other types of external reviews are verification and certification, assurance, and green ratings. 
Investors in green bonds can be divided between institutional investors and retail investors, asset owners and asset managers, foreign investors and domestic investors, and conventional investors and responsible investors. The distinction between conventional investors and responsible investors is an especially important one. Conventional investors are those whose investment decision-making processes focus on financial factors, such as profitability, cash flow, and debt levels. This information is provided in the financial statements of entities issuing public securities. The decision-making processes for responsible investors include both financial factors and nonfinancial factors, commonly referred to as environmental, social, and governance (ESG) factors. Environmental factors focus on an entity's environmental footprint such as carbon emissions; social factors deal with the treatment of employees, consumers, and communities; and governance factors address organizational structures. Information on ESG factors is available from some issuing entities and specialized research firms. Both conventional and responsible investors hold green bonds, but they are especially attractive to responsible investors because the proceeds from green bonds focus on projects and assets with positive environmental impacts.

A precise breakdown of who owns the outstanding stock of green bonds is not known. Placement details from green bond issuers indicate that they are largely held by institutional investors -including asset managers, pension plans, insurance companies, and banks -in proportions similar to conventional bonds. The main difference from conventional bonds is that green bonds are more likely to be held by investors with responsible investment mandates. Based on a small sample of issuer disclosures on investor type, about $45 \%-65 \%$ of green bonds appear to be placed with investors with responsible investment mandates. This is a much higher percentage than their respective share of globally managed assets, which is about $25 \%$. Most of the green bonds held by responsible investors are in broad ESG mandates - green bond funds total only about $\$ 1$ billion.

Several green bond indices have been created since 2014. The most widely used is the Bloomberg Barclays MSCl Green Bond Index, which is composed of about 150 green bonds issued in multiple currencies. Three other widely used indices are the S\&P Green Bond Select Index, the Bank of America Merrill Lynch Green Bond Index, and the Solactive Green Bond Index. Chinese renminbi-denominated bonds are explicitly excluded from the Bloomberg Barclays MSCI Index and the S\&P Green Bond Select Index. The ChinaBond Green Bond Index Series and the Central University of Finance and Economies (CUFE)$\mathrm{CNI}$ Green Bond Index Series provide measures of the PRC's green bond market.

Dedicated green bond listing boards have been established at a number of securities exchanges. The Luxembourg Stock Exchange and the London Stock Exchange have the largest number of green bond listings. The Singapore Exchange also lists green bonds. Both the Shanghai Stock Exchange and the Shenzhen Stock Exchange list green bonds on a pilot basis. Issuers of green bonds must meet the same listing requirements as conventional bonds, as well as additional requirements to confirm their green status, usually an external review confirming alignment with the GBP or other international or national standards. While a majority of green bonds are listed on at least one exchange, most trading occurs off exchange. 


\section{ASEAN+3 Experience with Local Currency Green Bonds}

The PRC is unique among Association of Southeast Asian Nations (ASEAN) +3 countries in that it has a large green bond market and national standards governing green bond issuance. ${ }^{1}$ The People's Bank of China published green bond guidelines in December 2015, which were followed by similar guidelines released by other regulatory agencies with responsibility for bond issuance. The guidelines are broadly similar, although those from the National Development and Reform Committee have wider eligibility rules, require only $50 \%$ of the net proceeds to be used for green projects, and do not require the use of a second opinion. The committee's guidelines apply to nonbank state-owned enterprises. The PRC was the largest issuer of green bonds in 2016, totaling about $\$ 36$ billion, continuing through the end of June 2017 with a further $\$ 6.2$ billion, of which $95 \%$ was denominated in renminbi. ${ }^{2}$

Market participants pointed to leadership by the Government of the PRC as critical to development of the local currency green bond market. Regulators established a clear policy framework linked to national policy goals that signaled to market participants the importance of participating in the green bond market. Issuers and underwriters wanted to participate in a new financial market that was being endorsed by government leaders. Perhaps more importantly, regulators encouraged issuance by indicating that green bond issues would be approved more quickly than those for conventional bonds.

Green bond markets in other ASEAN+3 countries are at a much earlier stage of development: ${ }^{3}$

(i) Japan: $\$ 2.2$ billion, $6 \%$ in Japanese yen;

(ii) Republic of Korea: $\$ 1.7$ billion, $0 \%$ in Korean won;

(iii) Singapore: $\$ 549$ million, $12 \%$ in Singapore dollars;

(iv) Philippines: $\$ 200$ million, $100 \%$ in Philippine pesos;

(v) Malaysia: $\$ 58$ million, $100 \%$ in Malaysian ringgit; and

(vi) Thailand: $\$ 92$ million, $100 \%$ in Thai baht. ${ }^{4}$

The markets in the Philippines, Malaysia, and Thailand consist of a single issue each. There had been two issues in Singapore through the end of August 2017.

Japan's Ministry of the Environment issued voluntary green bond guidelines in March 2017, which are aligned with the GBP. No other country in the region has issued guidelines, although the ASEAN Capital Markets Forum issued regional guidelines in the fourth quarter of 2017.

ASEAN+3 comprises the 10 members of the Association of Southeast Asian Nations (ASEAN) plus the PRC, Japan, and the Republic of Korea.

2 Authors' calculations based on Climate Bonds Initiative data, https://www.climatebonds.net/cbi/pub/data/bonds (accessed 7 July 2017).

Data through the end of August 2017; details are provided in Appendix I: Country Background Notes.

4 Thailand's total comprises the Bangchak Corporation's self-labeled green bond issuance in 2015, which, although accepted as green by Thai investors, was criticized by some in the international community because of the fossil fuel business of the company even though the bond proceeds were used to invest in its renewable energy subsidiary, the Stock Exchange of Thailand-listed BCPG. 
There is low awareness of green bonds in most ASEAN +3 countries. Many market participants are unfamiliar with green bonds and through the middle of 2017, those with some awareness often had only a cursory understanding. Market participants pointed to a lack of local currency green bond issues and the absence of investors with responsible investment mandates as reasons for the immaturity of green bond markets. The lack of a national policy framework in most markets was also seen as a concern, because issuers and investors in Asia appear less comfortable relying on industry norms than their counterparts in Europe and North America.

\section{Promoting Green Bond Markets}

A large number of policy tools are available to promote the development of green bond markets in ASEAN +3 countries. They can be divided into six general areas:

(i) setting preconditions for local currency green bond markets,

(ii) establishing a policy framework for green bonds,

(iii) expanding the supply of green bonds,

(iv) facilitating demand for green bonds,

(v) promoting general market development, and

(vi) supporting regional initiatives to develop green bond markets.

The overarching objective in promoting green bond markets is to increase investment in green projects and assets. Initiatives that simply favor one type of financing such as green bonds over alternatives will not achieve this objective even if they contribute to the development of green bond markets. Thus, efforts to increase the number of viable green projects brought to the market will have a greater impact than efforts to increase the supply of green bonds. Throughout ASEAN +3 , the binding constraint is the supply of market-ready projects, not financing.

The preconditions for local currency bond markets and private financing of green projects and assets should be in place prior to considering direct interventions in support of green bonds. This requires the following:

(i) continuing efforts to develop local currency bond markets;

(ii) continuing efforts to address the main bottleneck in attracting private investment to green financing opportunities, bringing investable projects to market;

(iii) considering creation of a national inventory of green projects; and

(iv) considering measures to enhance the financial viability of green projects.

Once these preconditions have been established, suggested national policy priorities for ASEAN +3 governments include the following:

(i) establishing a policy framework for green bonds by

(a) linking efforts to promote green bond markets into national strategies dealing with climate change and/or sustainable development, and

(b) adopting principles-based regulatory frameworks for green bonds with an inclusive definition; 
(ii) expanding the supply of and demand for green bonds by

(a) encouraging public entities to issue green bonds,

(b) encouraging public funds to invest in local currency green bonds,

(c) requiring issuers to report on ESG activities and measures,

(d) requiring institutional investors to report on ESG risk exposures and how they are being managed,

(e) mandating that knowledge of ESG analysis is a licensing requirement for investment managers,

(f) ensuring prudential requirements for financial institutions explicitly address climate change and other environmental risks,

(g) considering additional capital investment in existing credit enhancement vehicles to provide capacity to develop dedicated green portfolios,

(h) considering the potential benefits and costs of tax incentives for green projects in the context of national priorities and fiscal regimes, and

(i) supporting capacity building efforts in a targeted fashion;

(iii) promoting general market development by

(a) establishing a National Green Bond Development Committee (or a similar entity),

(b) providing support for awareness programs coordinated through a National Green Bond Development Committee (or a similar entity),

(c) supporting efforts by others to develop climate-aligned bond indices that include both labeled and unlabeled green bonds, and

(d) supporting efforts to establish a national network of green bond investors and issuers; and

(iv) supporting regional policy priorities by

(a) developing a regional technical assistance facility for green bond issuance,

(b) providing specific coverage of green bonds on AsianBonds Online,

(c) considering requesting the International Capital Market Association to present annual updates on the GBP and green bond market development globally to members of the ASEAN +3 Bond Market Forum (ABMF),

(d) considering encouraging the Credit Guarantee and Investment Facility to allocate a portion of guarantee operations to green bonds,

(e) continuing efforts to work with market participants to address barriers to cross-border bond issuance and investment under the ABMF,

(f) encouraging regional and global public entities to issue local currency green bonds, and

(g) encouraging regional and global public funds to commit to investing in local currency green bonds.

There are additional policy options available that have at least some merit, but further consideration of them should be set aside for now as alternatives are likely to provide greater impact relative to the costs involved. Policies that should not be considered at this time include the following:

(i) tax incentives or subsidies for issuers of green bonds,

(ii) tax incentives for investors in green bonds,

(iii) official assistance or financial support for national or regional green bond indices, 
(iv) official assistance or financial support for national or regional local currency bond exchange traded funds,

(v) official support for a regional securitization vehicle, and

(vi) official support for a regional network on green bonds.

Finally, there are policy options that have high risks in terms of potential fiscal, market, and financial stability impacts, and thus should not be further considered. These include proposals to weaken prudential standards or diverge from best practices in central bank reserve management, as the potential negative financial stability implications outweigh potential benefits.

The generally lower priority assigned to demand-oriented policies may seem counterintuitive given the generally low levels of knowledge and interest in green bonds among institutional investors in ASEAN+3 countries. On the face of it, it might seem that addressing these shortcomings would be important, as supply seldom creates its own demand. However, the situation in ASEAN+3 presents an unusual situation. Institutional investors in ASEAN +3 countries have strong demand for fixed income securities, especially high-quality, higher yielding corporate bonds. Because green bonds are similar in structure, term, and yield to conventional bonds, market participants indicated that green bonds could be easily placed with institutional investors. Green bonds are not popular with issuers because of the extra cost of issuance, not because of a perceived lack of demand.

The proper sequencing of policies is critical to the development of local currency green bond markets. A well-functioning local currency bond market is an essential precondition and, given that many green investments are best structured as project bonds, a local currency infrastructure bond market is also beneficial. Given the absence of institutional investors with responsible investment mandates to guide issuers and underwriters in the structuring of green bonds, a comprehensive policy framework for green bonds is also needed to support the development of local currency green bond markets. Only after these are in place should governments pursue other polices to promote green bond markets. Priority should be given to supply-oriented policies for the reasons noted above. Some demand-oriented policies and market development initiatives will also help, but their potential impact is more modest and will take longer to have an effect. Regional initiatives promoting cross-border investments in green bonds and those promoting increased supply should be given priority. 


\section{Abbreviations}

\begin{tabular}{|c|c|c|}
\hline ABMF & - & ASEAN+3 Bond Market Forum \\
\hline ABMI & - & Asian Bond Markets Initiative \\
\hline ABS & - & asset-backed securities \\
\hline ACMF & - & ASEAN Capital Markets Forum \\
\hline ADB & - & Asian Development Bank \\
\hline AIGCC & - & Asia Investor Group on Climate Change \\
\hline ASEAN & - & Association of Southeast Asian Nations \\
\hline ASEAN+3 & - & ASEAN plus the PRC, Japan, and the Republic of Korea \\
\hline ASrIA & - & Association for Sustainable and Responsible Investment in Asia \\
\hline BAPEPAM-LK & - & $\begin{array}{l}\text { Badan Pengawas Pasar Modal dan Lembaga Keuangan } \\
\text { (Indonesian Capital Markets and Financial Institutions } \\
\text { Supervisory Authority) }\end{array}$ \\
\hline bps & - & basis points \\
\hline BSP & - & Bangko Sentral ng Pilipinas \\
\hline $\mathrm{CBI}$ & - & Climate Bonds Initiative \\
\hline CBI Standard & - & Climate Bonds Standard \\
\hline CBRC & - & China Banking Regulatory Commission \\
\hline CECEP & - & China Energy Conservation and Environmental Protection \\
\hline CEFC & - & Clean Energy Finance Corporation \\
\hline CGIF & - & Credit Guarantee and Investment Facility \\
\hline CICERO & - & Centre for International Climate and Environmental Research \\
\hline CREB & - & Clean Renewable Energy Bonds \\
\hline CSDC & - & $\begin{array}{l}\text { China Government Securities Depository Trust and Clearing } \\
\text { Company }\end{array}$ \\
\hline CSR & - & corporate social responsibility \\
\hline CSRC & & China Securities Regulatory Commission \\
\hline CUFE & - & Central University of Finance and Economics \\
\hline EIB & - & European Investment Bank \\
\hline ETF & - & exchange traded fund \\
\hline ESG & - & environment, social, and governance \\
\hline FSA & - & Financial Services Agency \\
\hline GBP & - & Green Bond Principles \\
\hline GDP & - & gross domestic product \\
\hline GFC & - & Green Finance Committee \\
\hline HQLA & - & high-quality liquid assets \\
\hline ICMA & - & International Capital Markets Association \\
\hline IFC & - & International Financial Corporation \\
\hline INCR & - & Investor Network on Climate Risk \\
\hline
\end{tabular}




$\begin{array}{lll}\text { JGB } & - & \text { Japanese Government Bond } \\ \text { Lao PDR } & - & \text { Lao People's Democratic Republic } \\ \text { LSC } & - & \text { Lao Securities Commission } \\ \text { LSX } & - & \text { Lao Securities Exchange } \\ \text { MAS } & - & \text { Monetary Authority of Singapore } \\ \text { MDB } & - & \text { multilateral development bank } \\ \text { MOE } & - & \text { Ministry of the Environment } \\ \text { NAFMII } & - & \text { National Association of Financial Market Institutional Investors } \\ \text { NDC } & - & \text { Nationally Determined Contributions } \\ \text { NDRC } & - & \text { National Development and Reform Commission } \\ \text { OECD } & - & \text { Organisation for Economic Co-operation and Development } \\ \text { OJK } & - & \text { Otoritas Jasa Keuangan (Indonesian Financial Services Authority) } \\ \text { PACE } & - & \text { Property Assessed Clean Energy } \\ \text { PAIF } & - & \text { Pan-Asia Index Fund } \\ \text { PBOC } & - & \text { People's Bank of China } \\ \text { PPP } & - & \text { public-private partnership } \\ \text { PRC } & - & \text { People's Republic of China } \\ \text { SC } & - & \text { Securities Commission } \\ \text { SDG } & - & \text { Sustainable Development Goal } \\ \text { SEBI } & - & \text { Securities and Exchange Board of India } \\ \text { SGX } & - & \text { Singapore Exchange } \\ \text { SPV } & - & \text { special purpose vehicle } \\ \text { SRI } & - & \text { socially responsible investment } \\ \text { SRO } & - & \text { self-regulatory organization } \\ \text { SSA } & - & \text { supranational, sub-sovereign, and agency } \\ \text { UCITS } & - & \text { Undertaking for Collective Investment in Transferable Securities } \\ \text { UN } & - & \text { United Nations } \\ \text { UNPRI } & - & \text { United Nations Principles for Responsible Investment } \\ \text { US } & - & \text { United States } \\ \text { WHEEL } & - & \text { Warehouse for Energy Efficiency Loans }\end{array}$

CURRENCY EQUIVALENTS (as of 30 June 2017)

$\begin{array}{lll}\$ 1.00 & = & \mathrm{B} \$ 1.38 \\ \$ 1.00 & = & \mathrm{KR} 4,081 \\ \$ 1.00 & = & \mathrm{CNY} 6.78 \\ \$ 1.00 & = & € 0.87 \\ \$ 1.00 & = & \mathrm{Rp} 13,333 \\ \$ 1.00 & = & ¥ 112 \\ \$ 1.00 & = & \mathrm{W} 1,144 \\ \$ 1.00 & = & \mathrm{KN} 8,230 \\ \$ 1.00 & = & \mathrm{RM} 4.29 \\ \$ 1.00 & = & \mathrm{MK} 1,365 \\ \$ 1.00 & = & \mathrm{P} 50.40 \\ \$ 1.00 & = & \mathrm{S} \$ 1.37 \\ \$ 1.00 & = & \mathrm{B} 33.90 \\ \$ 1.00 & = & \mathrm{D} 22,730\end{array}$




\section{Introduction}

$T^{\mathrm{r}}$

ransitioning the global economy to a sustainable development path has become an existential imperative. For national leaders, this shift requires vision and commitment. It will also require trillions of dollars of investment in low-carbon technologies and infrastructure. This will only happen if every segment of the capital market and all capital market participants contribute to this effort. As the largest source of long-term investment capital, bond markets have an especially important role to play.

The green bond market is emerging as an important source of financing to meet the Sustainable Development Goals (SDGs) as set by the United Nations (UN). Since 2007, when the first green bond was issued by the European Investment Bank (EIB), the value of all outstanding green bonds has reached about $\$ 180$ billion. 'Perhaps another $\$ 600$ billion of bonds are aligned with climate change goals but are not officially labeled as green bonds. ${ }^{2}$ As impressive as these numbers are, they pale in comparison with the overall size of the global fixed income market and relative to the amount of investment capital needed to put the global economy on the path to sustainable development. ${ }^{3}$ The potential growth for green bond markets is enormous and the market has captured the attention of the global investment community.

The People's Republic of China (PRC) has become one of the largest issuers of green bonds. ${ }^{4}$ However, green bond issuance elsewhere in ASEAN +3 has been modest. ${ }^{5}$ Given the importance of green bond markets to promoting sustainable growth, this needs to change. This report provides recommendations to scale up green bond markets for infrastructure development in ASEAN+3 countries.

Based on Climate Bonds Initiative (CBI) data, total global issuance between 1 January 2007 and 30 June 2017 was about $\$ 235$ billion. However, many of these bonds have since matured. Bloomberg data suggest total green bond issuance of about $\$ 217$ billion through the end of 2016 , or about $\$ 20$ billion more than CBI data for the same period. See Bloomberg New Energy Finance. 2017. Green Bonds: 2016 in Review. As discussed later in the report, the main data sources have different inclusion criteria, resulting in divergent market statistics, although the broad messages are the same.

CBI. 2016. Bonds and Climate Change: The State of the Market in 2016. July.

Estimates vary but the global bond market is valued at about $\$ 100$ trillion. Public equity markets are valued at about $\$ 60$ trillion. Loans from banks and nonbank financing institutions are another key source of credit, but much of this is financed through bond markets. See Table 1 in International Monetary Fund. 2011. Global Financial Stability Report and McKinsey Global Institute. 2011. Mapping Global Capital Markets 2011.

4 In this report, references are often made to the amount of green bonds issued by a particular country. Unless noted otherwise, this refers to public and private entities within that country and not to sovereign bond issues.

5 ASEAN+3 comprises the 10 members of the Association of Southeast Asian Nations (ASEAN) plus the PRC, Japan, and the Republic of Korea. 
In particular, this report addresses three key questions:

(i) What are green bonds and how are they issued?

(ii) Why have local currency green bond markets been slower to develop outside of Europe, North America, and the PRC?

(iii) What can be done to promote the development of green bond markets?

\section{A. What Are Green Bonds?}

Green bonds are debt securities whose proceeds are used to finance projects or assets with positive environmental benefits. They are no different than conventional bonds except that their proceeds are earmarked for environmentally beneficial investments. The defining features of green bonds are: (i) the issuer commits to investing the proceeds in projects or assets meeting explicit eligibility criteria (often called the "green bond framework"); (ii) the proceeds are accounted for separately from other funds held by the issuer; (iii) the issuer provides ongoing reporting on the use of the proceeds and, where possible, the environmental impact of the investments; and (iv) prior to issuance, the bond is often evaluated or certified by an independent external reviewer attesting to the veracity its "green" claim.

Entities issue green bonds to improve their reputation and to broaden their investor base. Issuing green bonds demonstrates an entity's commitment to improving the environment. Green bonds are especially attractive to responsible investors who consider both financial and nonfinancial factors in their investment decision-making process. These investors may not have previously bought an issuer's conventional bonds. Investors buy green bonds to align their portfolios with responsible investment mandates, as well as to earn a competitive rate of return. Governments promote green bond markets to increase the amount of long-term financing available to support national commitments under the Paris Agreement and the UN's SDGs.

\section{B. Global Green Bond Markets}

There were about $\$ 180$ billion green bonds outstanding globally in the first half of 2017 . There are four main data sources, which all tell broadly the same story with respect to the recent rapid growth in the green bond market (Figure 1), but differ in the specifics of the size and composition of the market (Table 1). The differences among databases result in divergent headline numbers, with total green bond issuance in 2016 estimated to range from $\$ 81$ billion, ${ }^{6}$ to $\$ 93$ billion, ${ }^{7}$ to $\$ 95$ billion. ${ }^{8}$ Issuance through the first half of 2017 was on track to meet or exceed 2016 totals.

The widely quoted Climate Bonds Initiative (CBI) database includes labeled green bonds as well as bonds $\mathrm{CBI}$ has identified using Bloomberg data as originating with issuers deriving

\footnotetext{
Climate Bonds Initiative. https://www.climatebonds.net/front (accessed 14 August 2017). Estimated by Moody's. Bloomberg. 2017. Green Really Is Gold for These Bond Lovers. 9 March. Bloomberg New Energy Finance. 2017. Green Bonds: 2016 in Review. https://about.bnef.com/blog/green-bonds-2016 -review/ (accessed 12 September 2017).
} 
Figure 1: Green Bond Issues by Year, Two Leading Data Sources (\$ billion)

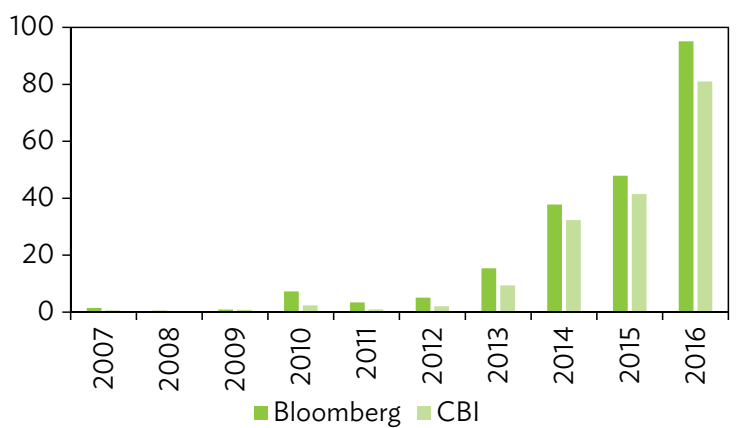

$\mathrm{CBI}=$ Climate Bonds Initiative.

Sources: Bloomberg New Energy Finance. 2017. Green Bonds: 2016 in Review; authors' calculations from Climate Bonds Initiative data, https://www.climatebonds.net/cbi/pub/data/ bonds (accessed 7 July 2017).

\section{Figure 2: Labeled and Pure Play Green} Bond Issues (\$ billion)

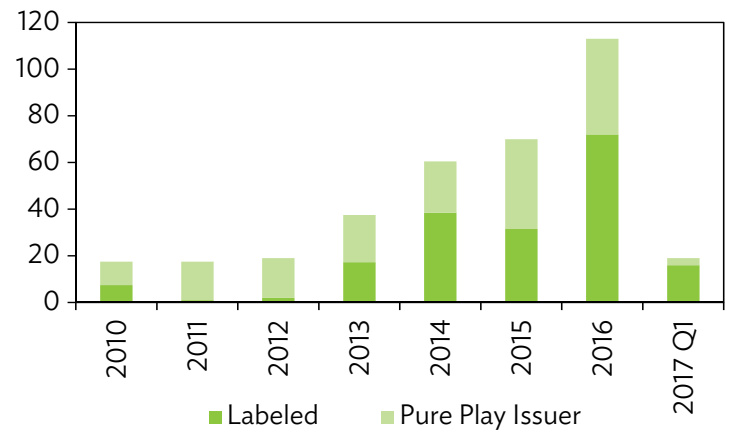

Sources: Fitch Ratings. 2017. Green Bonds: Fitch Ratings and Market Overview; Bloomberg data.

\section{Table 1: Green Bond Databases}

\begin{tabular}{|c|c|c|c|c|}
\hline Item & Bloomberg & $\begin{array}{l}\text { Climate Bonds } \\
\text { Initiative }\end{array}$ & Dealogic & $\begin{array}{c}\text { Green Bond Database } \\
\text { (Environmental } \\
\text { Finance) }\end{array}$ \\
\hline Criteria for inclusion & $\begin{array}{l}\text { All bonds self-labeled } \\
\text { as green, or identified } \\
\text { by the issuer as } \\
\text { an environmental } \\
\text { sustainability- } \\
\text { oriented bond issue } \\
\text { with clear additional } \\
\text { statements about } \\
\text { the commitment to } \\
\text { allocate proceeds } \\
\text { toward projects and } \\
\text { activities in the GBP } \\
\text { use of proceeds } \\
\text { categories }\end{array}$ & $\begin{array}{l}\text { All bonds aligned } \\
\text { with the GBP and } \\
\text { the Climate Bonds } \\
\text { Taxonomy }\end{array}$ & $\begin{array}{l}\text { Flagged based on } \\
\text { use of proceeds } \\
\text { and categorized by } \\
\text { Dealogic's green } \\
\text { categories, which are } \\
\text { broadly in line with } \\
\text { GBP use of proceeds } \\
\text { categories }\end{array}$ & $\begin{array}{l}\text { All bonds self-labeled } \\
\text { as green, a majority } \\
\text { of which are aligned } \\
\text { with the GBP, Climate } \\
\text { Bonds Certification, } \\
\text { and the PBOC Green } \\
\text { Bond-Endorsed } \\
\text { Project Catalogue }\end{array}$ \\
\hline $\begin{array}{l}\text { Number of green } \\
\text { bonds included } \\
\text { (Q1 2017) }\end{array}$ & 910 tranches & $\begin{array}{l}1,050 \text { tranches } \\
\text { (United States } \\
\text { municipal bonds } \\
\text { not separated in } \\
\text { tranches) }\end{array}$ & 489 tranches & 910 tranches \\
\hline
\end{tabular}

$\mathrm{CBI}=$ Climate Bonds Initiative, GBP = Green Bond Principles, PBOC = People's Bank of China, Q1 = first quarter.

Source: International Capital Markets Association. 2017. Summary of Green Bond Database Providers. https://www.icmagroup.org/assets/ documents/Regulatory/Green-Bonds/Green-Bond-Databases-Summary-Document-190617.pdf. 
more than $95 \%$ of revenues from climate-aligned activities ("pure play" companies as shown in Figure 2). ${ }^{9}$ Swedish bank SEB has complied a green bond library including only labeled green bonds with a recognized second opinion. ${ }^{10}$ This included 160 issuers through the end of June 2017 versus about 300 "green" issuers included in the CBI database, which does not require second opinions. Many of the excluded issuers are United States (US) cities and municipalities, which are active issuers of green bonds without second opinions.

There were about 25 issuers collectively accounting for $\$ 12.6$ billion in bonds that were coded as green in the Bloomberg database in early 2017 and were not in the CBI database, and an additional $\$ 10.8$ billion in bonds where specific issues appear to have been coded green by Bloomberg but were not included in the $\mathrm{CBI}$ database even though it includes other bonds by the same issuer." The CBI database includes about 75 US state and local governments, agencies, and universities not coded as green by Bloomberg that collectively have issued about $\$ 19$ billion in bonds classified as green by CBI. The CBI data also includes about 25 other issuers whose bonds are not coded as green by Bloomberg.

About $\$ 169$ billion in bond issuance, or $72 \%$ of the $\mathrm{CBI}$ database and $78 \%$ of bonds coded as green in the Bloomberg database, were included in both databases at the end of June 2017.12 Thus, about one-quarter of the total green bond issuance in the Bloomberg and CBI databases is not included in the other database. Some of the larger differences between the two are that $\mathrm{CB}$ I includes almost $\$ 9$ billion in World Bank bonds, none of which are green coded by Bloomberg, and inclusion in the Bloomberg database of about $\$ 4.6$ billion worth of International Bank for Reconstruction and Development bonds, which are not in the $\mathrm{CBI}$ database. The differences tend to largely cancel each other out in aggregate, but can become more apparent when doing sectoral or regional analysis.

The green bond market originated in 2007 with issuance by the EIB of a "climate awareness bond." The market through 2010 consisted entirely of supranational issues, with the World Bank and Nordic Investment Bank being early adopters following the EIB inaugural issue. Kommunalbanken, a government-owned financing vehicle for the Norwegian local government sector, was the first government agency to issue green bonds in 2010, followed in 2011 and 2012 by subnational governments and agencies in a number of countries. The first corporate green issue was by Bank of America in 2013.

\footnotetext{
In addition to the four green bond databases, CBI compiles data on "climate-aligned bonds," which include bonds financing climate-aligned assets that do not carry a green label, in addition to labeled green bonds. Through the middle of 2016, CBI had identified a climate-aligned universe of 780 issuers financing assets across its identified climate themes - transport, energy, buildings and industry, water, waste and pollution control, and agriculture and forestry - totaling $\$ 694$ billion outstanding, of which 17\% were labeled green bonds. See CBI. 2016. Bonds and Climate Change: The State of the Market in 2016. Throughout this report, unless noted otherwise, references are to the more narrowly defined green bonds rather than climate-aligned bonds.

10 See http://greenlibrary.greenfinancing.org/Account/Login?ReturnUrl=\%2F.

11 Data in this paragraph were drawn from authors' calculations using CBI data. Climate Bonds Initiative. Labelled green data. https://www.climatebonds.net/cbi/pub/data/bonds (accessed 7 July 2017) and Bloomberg-labeled green bond data published in RBC Capital. 2017. Green Bonds: Green is the New Black. https://www.rbccm.com/assets/rbccm/docs/ news/2017/green-is-the-new-black.pdf A small part of the difference is due to our conversion of all non-US dollar issues to US dollars using exchange rates at the end of 2016, while Bloomberg data on US dollar equivalents are based on exchange rates at the date of issue. By far, the larger difference is attributable to differing inclusions and exclusions in the databases.

12 T. Ehlers and F. Packer. 2017. Green Bond Finance and Certification. Bank for International Settlements Quarterly Review. September. pp. 89-104.
} 
The green bond market began with dollar and euro issues, but has quickly expanded to include a wide range of currencies. Through the end of June 2017, green bonds had been issued in 27 currencies, with almost three-quarters of the total value comprising dollars and euros; Chinese renminbi issues accounted for the next largest share at 11\% (Figure 3). In many cases, issuance in local currencies has been led by the multilateral development banks (MDBs). For example, the International Financial Corporation (IFC) has issued green bond tranches across a range of currencies including the Turkish lira, South African rand, Indonesian rupiah, Peruvian sol, and Brazilian reals, in addition to dollars and euros.

Issuers in 38 jurisdictions, in addition to supranationals, had brought green bonds to market through the end of June 2017 (Figure 4). In many countries, there has been only one or a few issues, with the most established markets being in the PRC, the US, and Europe. The larger number of countries with green bond issuers relative to currencies of green bond issuance is due to the common practice of issuing dollar- or euro-denominated bonds rather than local currency bonds. This may reflect a desire by issuers to target investors with responsible or environmental, social, and governance (ESG) mandates who are likely to have greater appetite for bonds denominated in reserve rather than local currencies.

Corporate issuance has been increasing rapidly, with financial and nonfinancial corporates accounting for $57 \%$ of issues in the first half of 2017 (Figure 5). This strong growth is diluting the market share of the MDBs, with the result that supranational issuance comprised only $7 \%$ of all green bonds in the first half of 2017. France, driven by a $€ 7$ billion sovereign that is the largest green bond issue to date, saw the greatest growth in green bonds outstanding during the first half of 2017 , and now comprises about $10 \%$ of the total market.

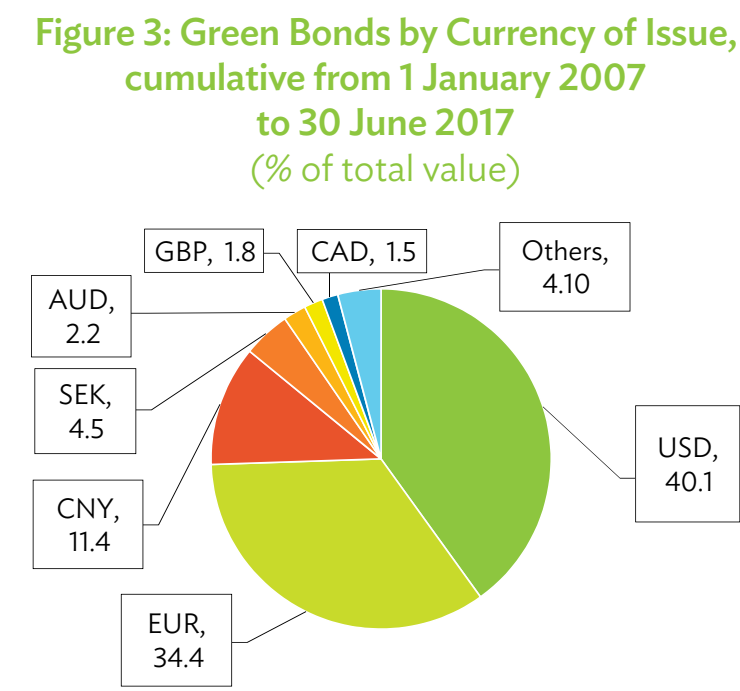

AUD $=$ Australian dollar, $C A D=$ Canadian dollar, $\mathrm{CNY}=$ yuan, $\mathrm{EUR}$ = euro, $\mathrm{GBP}=$ pound sterling, SEK = Swedish krona, USD = United States dollar.

Source: Authors' calculations from CBI data. Climate Bonds Initiative. Labelled green bonds data. https://www .climatebonds.net/cbi/pub/data/bonds (accessed 7 July 2017).
Figure 4: Green Bonds by Country of Issue, cumulative from 1 January 2007 to 30 June 2017

(\% of total value)

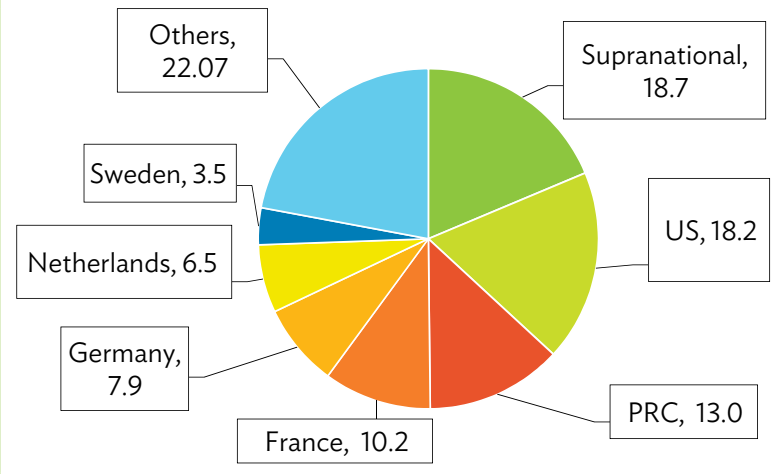

PRC = People's Republic of China, US = United States.

Source: Authors' calculations from CBI data. Climate Bonds Initiative. Labelled green bonds data. https://www .climatebonds.net/cbi/pub/data/bonds (accessed 7 July 2017). 


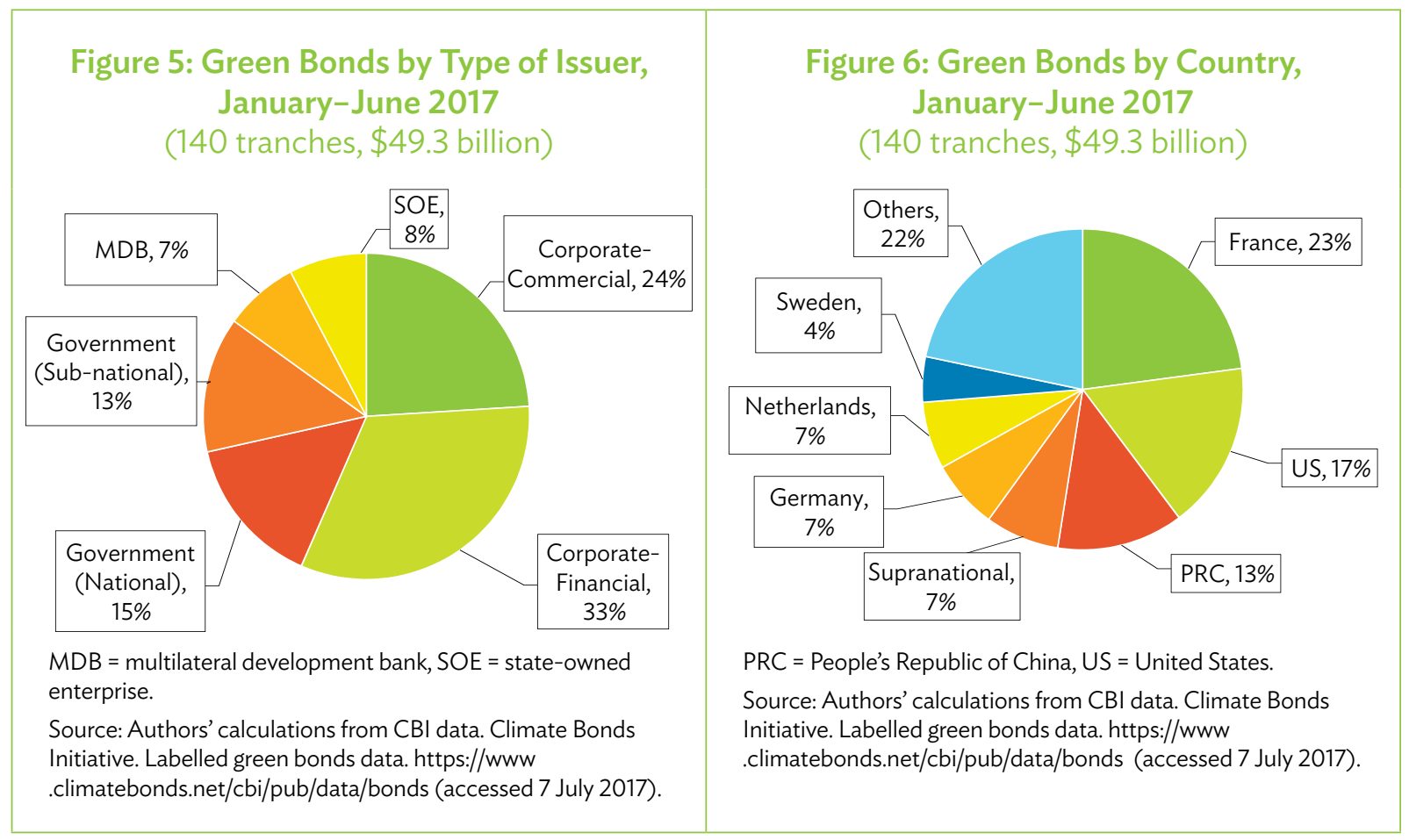

The PRC was the largest source of green bond issuance in 2016 and continues to be among the leading countries in both issuance and green bonds outstanding. The rapid growth in the green bond market in the PRC has been driven by bank issues, with banks in the PRC being four of the five largest financial green bond issuers in 2016 and again in the first half of 2017 (Table 2). The PRC's share of financial green bond issuance is even higher if the development banks are considered as financial rather than government issuers, as both China Development Bank ( $\$ 1.44$ billion) and the Agricultural Development Bank of China ( $\$ 0.58$ billion) would rank in the top 10 issuers in the first half of $2017 .{ }^{13}$ Most green bonds from PRC issuers have been denominated in Chinese renminbi.

Renewable energy and energy efficiency account for about half of the largest corporate nonfinancial green bond issuers, which include Iberdrola, Southern Power, Electricite de France, TenneT Holdings, Nordex, Greenko, Engie, Enel, SNCF, and Neerg Energy (Table 3). While there are no PRC issuers among the largest nonfinancial corporates, both of the Hong Kong, China-domiciled issuers in 2016 ranked in the top 10.

Green bonds tend to be highly rated, with $\mathrm{CBI}$ identifying less than $4 \%$ of green bonds having a less than investment grade rating. ${ }^{14}$ An additional $14 \%$ are unrated-many of the unrated bonds in the CBI database are US local government and agency issuers. In large part, the generally high credit ratings of green bonds reflect the prevalence of government, supranational and agency, and financial issuers in the market, as they all tend to be highly

Despite its name, Shanghai Pudong Development Bank is a joint-stock commercial bank.

CBI. 2016. Bonds and Climate Change: The State of the Market in 2016. Investment grade are bonds rated BBB- (or equivalent) and above. Bonds rated BB+ or below are called "high yield" (or less charitably "junk") bonds. 


\section{Table 2: Top 10 Financial Corporate Green Bond Issuers}

\begin{tabular}{l|c|l|c}
\hline 2016 & \multicolumn{2}{|c}{ January-June 2017 } \\
\hline $\begin{array}{l}\text { Issuer } \\
\begin{array}{l}\text { Shanghai Pudong Development Bank } \\
\text { (PRC) }\end{array}\end{array}$ & \$ billion & \multicolumn{1}{|c}{ Issuer } & \$ billion \\
\hline Bank of Communications (PRC) & 4.32 & Bank of Beijing (PRC) & 2.15 \\
\hline Bank of China (PRC) & 2.03 & National Bank of Abu Dhabi (UAE) & 0.59 \\
\hline Toyota Financial Services (US) & 1.60 & Bank of Nanjing (PRC) & 0.58 \\
\hline Bank of Quingdao (PRC) & 1.19 & Harbin Bank (PRC) & 0.58 \\
\hline Bank of America (US) & 1.00 & Berlin Hyp (Germany) & 0.53 \\
\hline ABN AMRO (Netherlands) & 0.53 & Nordea (Sweden) & 0.53 \\
\hline Berlin Hyp (Germany) & 0.53 & Intesa Sanpaolo SpA (Italy) & 0.53 \\
\hline BNP Paribas (France) & 0.53 & National Australia Bank (Australia) & 0.53 \\
\hline Rabobank (Netherlands) & 0.53 & SEB (Sweden) & 0.53 \\
\hline
\end{tabular}

PRC $=$ People's Republic of China, UAE = United Arab Emirates, US = United States.

Sources: Authors' calculations from CBI data. Climate Bonds Initiative. Labelled green bonds data. https://www .climatebonds.net/cbi/pub/data/bonds (accessed 7 July 2017).

\section{Table 3: Top 10 Nonfinancial Corporate Green Bond Issuers}

\begin{tabular}{l|c|l|c}
\hline 2016 & \multicolumn{1}{|c}{ January-June 2017 } \\
\hline Issuer & \$ billion & \multicolumn{1}{|c}{ Issuer } & \$ billion \\
\hline Iberdrola (Spain) & 3.19 & TenneT Holdings (Netherlands) & 2.11 \\
\hline Southern Power (US) & 2.14 & Engie (France) & 1.58 \\
\hline Mexico City Airport Trust (Mexico) & 2.00 & Iberdrola (Spain) & 1.58 \\
\hline Electricite de France (France) & 1.93 & Enel (Italy) & 1.32 \\
\hline TenneT Holdings (Netherlands) & 1.67 & SNCF (France) & 1.05 \\
\hline Apple Inc. (US) & 1.50 & Apple Inc. (US) & 1.00 \\
\hline MTR Corporation (Hong Kong, & & Fibria (Brazil) & 0.70 \\
\hline China) & 0.60 & & 0.58 \\
\hline Nordex (Germany) & 0.58 & Kaiser Permanente (US) & 0.50 \\
\hline Greenko Investment (India) & 0.50 & Inversiones CMPC (Chile) & 0.48 \\
\hline Link REIT (Hong Kong, China) & 0.50 & Neerg Energy (India) & \\
\hline US = United States. & & &
\end{tabular}

US = United States.

Note: This table includes government-controlled corporations.

Sources: Authors' calculations from CBI data. Climate Bonds Initiative. Labelled green bonds data. https://www .climatebonds.net/cbi/pub/data/bonds (accessed 7 July 2017).

rated on a local if not international scale. This contrasts with the US corporate bond market where about one-fifth of issues are high yield. However, this is consistent with investor expectations in ASEAN+3, where market participants report very little demand for highyield instruments. 
$\mathrm{CB}$ I reports that the average tenor of labeled green bonds is from 5 years to 10 years, which contrasts with its broader climate-aligned universe, where $70 \%$ of issues have tenors of 10 years or longer..$^{15}$ Bloomberg data indicates about $20 \%$ of green bonds have a tenor of 10 years or longer, with the most common tenor being from 5 years to 10 years. ${ }^{16}$ Longer tenors for pure play companies and other issuers identified by CBI as climate-aligned may reflect a matching of the term of the financing with project payback periods. As detailed in this report, the pricing of green bonds does not systematically vary from the pricing of otherwise similar non-green bonds.

\section{What Is Driving the Growth of Green Bond Markets?}

Green bond markets have experienced tremendous growth over the past 5 years. Four factors in particular have propelled this growth.

First, there is much greater awareness and statements of support for the need to develop green financing mechanisms to transition economies to a sustainable development path, as well the added risk of securities linked to high-carbon activities. This is reflected in international initiatives such as the Paris Agreement, the UN SDGs, the G20 Green Finance Study Group, and the Financial Stability Board's Task Force on Climate-Related Financial Disclosures. These initiatives highlight the very large funding needs to put the global economy on a sustainable development path, as well as the financial risks to investors of global inaction or from their exposure to fossil fuel industries as climate policies are tightened. As countries put in place policies to meet their commitments under these global initiatives, the development of green bond markets is an important tool to fund green investments and lessen the financial risks faced by institutional investors.

Second, the MDBs and other public entities provided leadership through demonstration issuance. In the 5 years following the first green bond issue in 2007, MDBs accounted for almost all green bond issuance. Following the lead of Norway's Kommunalbanken, which first issued green bonds in 2011, government agencies elsewhere provided demonstration issues, including the Export-Import Bank of Korea in 2013 and the Development Bank of Japan in 2014. These early issues increased awareness of green bonds, helped to standardize green definitions and post-issuance reporting requirements, encouraged underwriters to develop green bond capabilities, and demonstrated to issuers that green bonds would be well received by investors. The MDBs have also actively supported green bond issuance from private entities by providing technical assistance and financial support.

Third, the Green Bond Principles (GBP) provided an objective standard to judge the credibility of green bond issues. They, in effect, codified emerging industry norms. Their importance lies in providing a road map for entities to follow when issuing green bonds, and a framework for external reviewers and investors to assess the merits of new green bond issues. As importantly, the International Capital Market Association's (ICMA) oversight of

Footnote 14

Fitch Ratings. 2017. Green Bonds: Fitch Ratings and Market Overview using Bloomberg data. 
the GBP provided a forum for a wide range of stakeholders to address weaknesses in the GBP. The work of the CBI in promoting the GBP and its own Climate Bonds Standard (CBI Standard) has also been a key driving force.

Fourth, responsible investors provided a ready market for green bonds. Their investment approach integrates financial and nonfinancial factors into their investment decisionmaking process. Through this lens, environmental risks and opportunities become important considerations when evaluating an investment's potential risk-adjusted return. Because they fund environmentally beneficial projects and assets, green bonds hold strong appeal for responsible investors. Their presence demonstrated to issuers that there was demand for green bonds - in fact, responsible investors have taken the largest allocation of many green bond issues. Responsible investors have also worked with issuers, on a bilateral basis and through the ICMA, to shape industry norms on green bonds.

These four factors should not be viewed in isolation from one another. It is their combined effect that has mattered. In the absence of any one of these factors - the need for green financing, a clear policy framework, ongoing supply, and growing demand-green bond markets would not have, and will not continue to, develop.

\section{Barriers to Green Bond Markets}

The G20 Green Finance Study Group identified eight barriers hampering the development of green bond markets. ${ }^{17}$ These are summarized and grouped into five broad policy areas in Table 4.

Market participants and regulators in ASEAN +3 countries echoed these concerns, although they placed greater importance on some relative to others. A key impediment is seen to be the lack of a comprehensive policy framework governing the issuance of green bonds. Even those familiar with the GBP, and the contributions they have made to the development of green bond markets in other economies, were uncomfortable with the GBP's lack of precision and voluntary nature. Many market participants pointed favorably to the experience of the PRC after it put in place comprehensive regulations governing the issuance of green bonds. More generally, Asian issuers, investors, and regulators appear less comfortable with the guidance provided by industry norms than their European and North American counterparts, reflecting a preference for "black letter" regulation and the evident success of the approach in the PRC. National regulations should be guided by the $\mathrm{GBP}$, but the GBP alone are likely insufficient for the green bond market to develop across ASEAN+3.

Another barrier identified by market participants and regulators in ASEAN+3 countries is the absence of a linkage between national goals to improve the environment, as reflected

Adapted from G20 Green Finance Study Group. 2016. Green Bonds: Country Experiences, Barriers, and Options. pp. 28-9. See also Organisation for Economic Co-operation and Development. 2017. Mobilising Bond Markets for a LowCarbon Transition. pp. 52-4; I. Shishlov, R. Morel, and I. Cochran. 2016. Beyond Transparency: Unlocking the Full Potential of Green Bonds, Institute for Climate Economics. pp. 13-24; and European Commission. 2016. Study on the Potential of Green Finance for Resource-Efficient Investments. pp. 38-43. 


\section{Table 4: Barriers to the Development of Green Bond Markets}

\begin{tabular}{|c|c|c|}
\hline Policy Area & Barrier & Details \\
\hline $\begin{array}{l}\text { Preconditions for local } \\
\text { currency green bond } \\
\text { markets }\end{array}$ & $\begin{array}{l}\text { General challenges to bond } \\
\text { market development }\end{array}$ & $\begin{array}{l}\text { - Underdevelopment of an } \\
\text { institutional investor base } \\
\text { - Underdevelopment of credit rating } \\
\text { capabilities } \\
\text { - A lack of benchmark yield curves } \\
\text { - A lack of hedging instruments } \\
\text { - Poor liquidity }\end{array}$ \\
\hline $\begin{array}{l}\text { Policy framework for } \\
\text { Green Bonds }\end{array}$ & $\begin{array}{l}\text { Lack of local green bond } \\
\text { guidelines }\end{array}$ & $\begin{array}{l}\text { A lack of domestic definitions and } \\
\text { disclosure requirements for green } \\
\text { bonds }\end{array}$ \\
\hline \multirow[b]{2}{*}{$\begin{array}{l}\text { Expanding the supply } \\
\text { of green bonds }\end{array}$} & $\begin{array}{l}\text { Cost of meeting green bond } \\
\text { requirements }\end{array}$ & $\begin{array}{l}\text { Higher issuance costs, especially } \\
\text { related to external reviews }\end{array}$ \\
\hline & $\begin{array}{l}\text { Lack of supply of labeled green } \\
\text { bonds }\end{array}$ & $\begin{array}{l}\text { - Limited supply due to a lack of } \\
\text { "bankable" projects and issuers not } \\
\text { seeking green labels for bonds that } \\
\text { would meet existing standards }\end{array}$ \\
\hline \multirow{2}{*}{$\begin{array}{l}\text { Facilitating demand } \\
\text { for green bonds }\end{array}$} & $\begin{array}{l}\text { Lack of domestic green bond } \\
\text { investors }\end{array}$ & $\begin{array}{l}\text { Too few investors pursuing } \\
\text { responsible investing strategies }\end{array}$ \\
\hline & $\begin{array}{l}\text { Difficulties for international } \\
\text { investors to access local markets }\end{array}$ & $\begin{array}{l}\text { - Cross-border barriers to domestic } \\
\text { bond markets }\end{array}$ \\
\hline \multirow[t]{2}{*}{$\begin{array}{l}\text { Market development } \\
\text { initiatives }\end{array}$} & $\begin{array}{l}\text { Lack of awareness of the } \\
\text { benefits of green bonds and } \\
\text { existing international guidelines } \\
\text { and standards }\end{array}$ & $\begin{array}{l}\text { - A lack of understanding of the } \\
\text { benefits of green bond markets in } \\
\text { meeting national environmental } \\
\text { priorities } \\
\text { - A lack of awareness of international } \\
\text { standards and how they work }\end{array}$ \\
\hline & $\begin{array}{l}\text { Lack of green bond ratings, } \\
\text { indices and listings }\end{array}$ & $\begin{array}{l}\text { A lack of supporting infrastructure } \\
\text { to support the development of } \\
\text { green bond markets }\end{array}$ \\
\hline
\end{tabular}

Source: G20 Green Finance Study Group.

in countries' nationally determined contributions (NDCs) as part of the Paris Agreement or national commitments associated with the UN SDGs, and the development of green bond markets. Doing so, as the PRC has done, would elevate the importance of green bond markets among policy makers and with the public. This, in turn, would lead to more political support and resources for the development of green bond markets

An additional barrier is that there are few responsible, sustainable, or green investment mandates among domestic institutional investors across ASEAN +3 . As a result, there is no domestic institutional investor demand for green bonds, which is a catalyst for the marketdriven development of domestic green bond issuance. 


\section{E. Objectives}

This report provides a comprehensive introduction to green bonds for policy makers and market participants in ASEAN+3. A wide range of policy framework activities and direct interventions, drawing on experience and recommendations from across the region and globally, are presented and evaluated. Policy actions appropriate to the circumstances of each country are required, with it being particularly important to focus scarce resources on actions most likely to have a major impact. Equally importantly, policy makers need to avoid actions with potentially destabilizing or other counterproductive unintended consequences. 


\section{Green Bonds-A Primer}

reen bonds are unfamiliar to many issuers, investors, and regulators, particularly in

7 countries where few green bonds have been issued and few investors have embraced responsible investing strategies. This chapter discusses the main features of green bonds and addresses some of the controversies surrounding them. In addition, the chapter provides an Association of Southeast Asian Nations and the People's Republic of China (PRC), Japan, and the Republic of Korea (ASEAN+3) perspective on green bond markets based on interviews with market participants and officials in the PRC, the Republic of Korea, Malaysia, the Philippines, Singapore, and Thailand conducted in May and June 2017.

\section{A. Background}

Green bonds are debt securities whose proceeds are used to finance projects or assets with positive environmental benefits. They are no different than conventional bonds except that their proceeds are earmarked for environmentally beneficial investments. The defining features of green bonds are: (i) the issuer commits to investing the proceeds in projects or assets meeting explicit eligibility criteria (often called the "green bond framework"); (ii) the proceeds are separated from other funds held by the issuer; (iii) the issuer provides ongoing reporting on the use of the proceeds and, where possible, the environmental impact of the investments; and (iv) prior to issuance, the bond is often evaluated or certified by an independent external reviewer attesting to the veracity of its "green" claim.

Green bonds take several forms, including use-of-proceeds bonds as well as any structure used in conventional bond financing. Typical projects supported by green bonds include renewable energy, energy efficiency, sustainable waste management, sustainable land use, biodiversity conservation, low carbon transportation, and clean water. Entities issuing green bonds include multilateral development banks (MDBs), national and local governments, public agencies, financial institutions, nonfinancial corporations, and specialized investment vehicles. Green bonds may be used to refinance existing projects and assets or to finance new ones.

Green bonds are part of the broader category of responsible investments that seek to improve environment, social, and governance (ESG) outcomes (Figure 7). ${ }^{18}$ The term green

In its earliest version, responsible investing took the form of ethical investing, where certain companies or sectors were excluded from an investment portfolio if their activities conflicted with the investor's religious or moral beliefs. It later evolved to socially responsible investing, ESG investing, and mission-based investing. Sustainable investing and impact investing also fall under the responsible investing rubric. Corporate social responsibility is the real economy counterpart to responsible investing. Corporate social responsibility deals with the behavior of issuers whereas responsible investing is concerned with the investment processes of investors. There are technical differences among these concepts, but these are unimportant for the purposes of this report. 
bonds is sometimes used interchangeably with "climate bonds," "climate-aligned bonds," and "sustainable bonds." Climate bonds are a narrower concept than green bonds because they exclude environmentally beneficial projects and activities unrelated to climate change (e.g., clean water). The $\mathrm{CBI}$ compiles data on climate-aligned bonds, which it defines to include labeled green bonds and bonds from issuers that derive $95 \%$ of their revenue from climate-aligned assets. Sustainable bonds are a broader concept than green bonds because they include sustainable projects and activities where environmental benefits are not necessarily the primary motivating factor (e.g., poverty reduction). Sustainable bonds lacking clear environmental impacts are usually referred to as "social bonds." While precise definitions of what constitutes a green bond remains contested, globally acceptable guidelines and standards have emerged.

\section{Figure 7: Green Subsets of Responsible Investments}

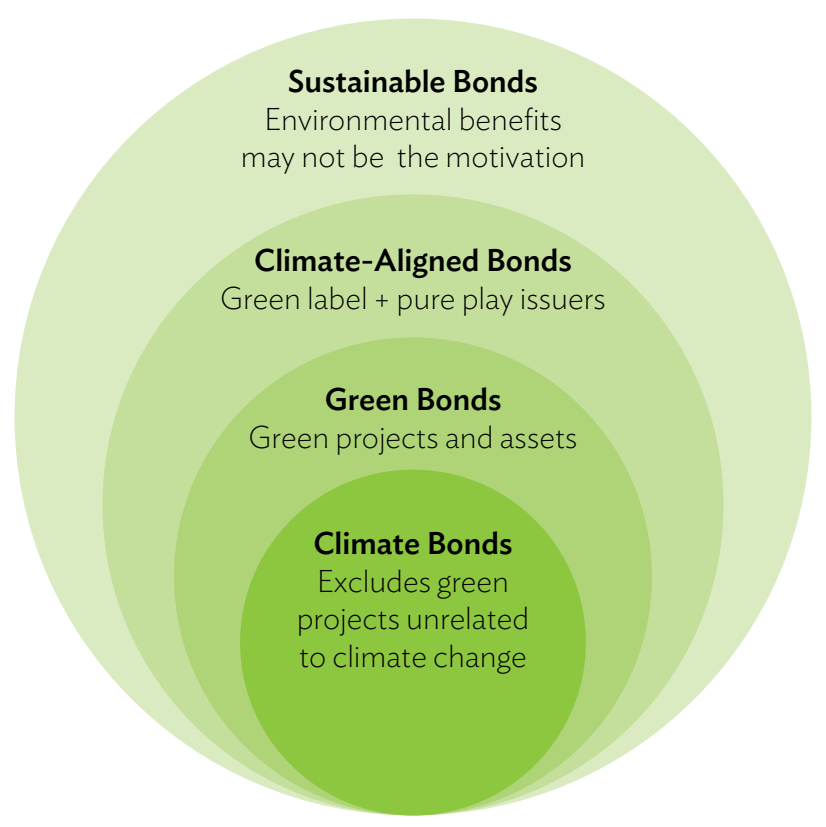

Source: Authors' illustration.

\section{B. Why Issue Green Bonds?}

In terms of macro-policy, the Organisation for Economic Co-operation and Development (OECD) identified six reasons why green bond markets should be promoted by governments. ${ }^{20}$

Other names that have been used for green bond issues include climate awareness bonds, environmental sustainability bonds, and sustainable yield bonds.

20 OECD. 2017. Mobilising Bond Markets for a Low-Carbon Transition. Paris. pp. 36-38; I. Shishlov, R. Morel, and I. Cochran. 2016. Beyond Transparency: Unlocking the Full Potential of Green Bonds. Institute for Climate Economics. June. pp. $9-12$. 
Green bond markets:

(i) provide an additional source of green financing to meet government commitments under the Paris Agreement and the Sustainable Development Goals,

(ii) enable more long-term green financing,

(iii) enhance issuers' reputations and clarify environmental strategies,

(iv) offer potentially lower cost of funds to issuers, ${ }^{21}$

(v) facilitate the "greening" of traditionally brown sectors, and

(vi) make new green financial products available to responsible and long-term investors.

At the level of individual agents, why would entities want to issue green bonds? After all, they are identical to conventional bonds in terms of their economic structure, yet green bonds are subject to higher administrative expenses for issuance and ongoing reporting. The two major reported benefits of green bonds to issuers are:

(i) Improved reputation. The issuance of green bonds signals to investors and the public an entity's commitment to invest in environmentally beneficial projects and assets. This can generate positive media coverage and increase an issuer's brand value with stakeholders. Issuing green bonds is also a tangible act by entities demonstrating their commitment to corporate social responsibility (CSR) goals.

(ii) Broader investor base. Institutional investors can be divided between conventional and responsible investors. ${ }^{22}$ Conventional investors focus on financial factors in making their investment decisions. So too do responsible investors, but they also consider nonfinancial factors as well, such as environmental impacts. Green bonds are especially attractive to responsible investors because they are used to fund environmentally beneficial projects. Issuers have reported that green bonds have been bought by responsible investors who had not previously purchased their conventional bond issues. A broader investor base is desirable because it increases the potential demand for issues, which may allow for larger issue sizes and better pricing. ${ }^{23}$ It may also stabilize pricing in secondary markets because there are more potential buyers and because responsible investors are more likely to hold a bond to maturity.

Other reported potential benefits to issuers from issuing green bonds are deeper relationships with investors by encouraging dialogue on environmental issues, tax incentives and subsidies that may be available in some jurisdictions, and better internal governance and reporting of their sustainability strategies.

Different reasons appear to have motivated the issuance of local currency green bonds in the PRC. The most commonly cited motivation was a faster approval process. After December 2015, regulators signaled to market participants that requests to issue bonds would be approved more quickly if they were structured as green bonds. This was certainly the case in 2016, although some underwriters indicated that the speed of approval converged to that of conventional bonds in 2017.

This is discussed in more detail later in the chapter

This is discussed in more detail later in the chapter.

This claim of better pricing is contentious and is discussed later in the chapter. 
A second factor was the desire to participate in a new financial market. Underwriters in particular were keen to develop their capabilities in a new market and aggressively pursued their clients to issue green bonds. Policy makers placed high importance on the development of a green bond market in the PRC, and issuers and underwriters were responsive to policy initiatives.

Issuers and underwriters in the PRC also indicated that new investors were not attracted to yuan (CNY)-denominated green bond issues. Foreign investors hold a small share of the outstanding CNY-denominated debt and responsible investing has not taken hold among domestic investors in the PRC. Green bonds were placed with the same domestic investors purchasing the issuers' conventional bonds, which has also been the case for entities issuing local currency green bonds in other ASEAN +3 countries.

Green bonds can present risks to issuers. Foremost among them is that the green credentials of the bond are questioned by investors or environmental nongovernment organizations. Charges of "greenwashing" can occur even when the Green Bond Principles (GBP) have been followed. ${ }^{24}$ This risk is greater for entities in the resource-extraction sector or that have poor environmental records. A related risk is the possibility of changes to international norms during the life of the green bond. If norms become more stringent, issuers may face higher reporting costs on their outstanding green bonds or risk bad publicity for not meeting these new requirements.

\section{Policy Framework for Green Bonds}

Green bond markets have developed largely in the absence of a formal public policy framework. Instead, the market has been guided by industry-developed norms and voluntary standards. The most important of these are the GBP and the CBI Standard. Before 2015, no country had issued specific guidelines governing the issuance of green bonds. Green bonds were issued under existing securities rules and the labeling of a bond as "green" was left entirely up to the issuer. However, investors and other stakeholders would only accept them as green bonds if they were issued in accordance with industry norms, such as the GBP. In December 2015, the PRC issued specific rules governing the issuance of green bonds, followed by India in May 2017.

\section{Green Bond Definitions}

In most jurisdictions any issuer can label their bond as "green" because the term is not legally defined. The PRC and India are exceptions. In practice, issuers usually label their bonds green only if they comply with the GBP; the CBI Standard; or national guidelines, standards, and regulations governing green bond issuance. Global rating agencies, such as Moody's Investor Services and S\&P Global Ratings, provide environmental ratings, although their evaluation criteria are closely aligned with the GBP and CBI Standard and their use is not yet widespread. Eligibility criteria for green bond indices and green bond listings on

Spanish oil refiner Repsol issued a green bond in April 2017 with a second opinion by Vigeo Eiris, but the issue is excluded from the CBI green bond database (and major green bond indices) because incremental improvements in fossil fuel refining are not considered to make a insufficient contribution to reducing emissions. 
securities exchanges provide additional definitions of green bonds, but they too closely follow the GBP.

Several green bond databases have been created. The best known is maintained by the $\mathrm{CBI}$. Others include Bloomberg, SEB, and Environmental Finance. There are also green bond lists available from index providers and securities exchanges, although these tend to be less complete. Because of differing criteria, these lists are not identical and thus a bond classified as green by one source may not be by another. This is not unusual in financial markets. Inclusion lists compiled by different providers purportedly for the same type of security often differ. The lack of a standard definition tends to trouble policy makers more than market participants.

\section{a. Green Bond Principles}

The GBP are voluntary guidelines on the issuance of green bonds originally drafted by four investment banks and now overseen by International Capital Markets Association. ${ }^{25}$ First issued in January 2014, their purpose is to legitimize the emerging green bond market by providing issuers and underwriters with guidance on how to issue green bonds and the level of disclosure to make available to investors. The GBP were revised in March 2015, June 2016, and June 2017 in response to input from a broad set of stakeholders. As of 1 March 2017, 132 investors, issuers, and underwriters were members of the GBP. Another 93 organizations are observers. Five members ${ }^{26}$ and seven observers ${ }^{27}$ are from ASEAN +3 countries. Due to its large membership, transparent and inclusive governance structure, and growing recognition by policy makers and regulators, the GBP have achieved broad market acceptance and legitimacy.

The GBP are composed of guidelines in four areas.

Part 1 deals with the use of proceeds. The guidelines require issuers to specify eligibility criteria (the green bond framework) in offering documents and to ensure that all designated project categories "provide clear environmental benefits, which will be assessed and, where feasible, quantified by the issuer." The GBP also provide a list of broad categories of eligible green projects, though the GBP acknowledge that the list is intended to be "indicative" of the types of projects supported by green bonds and that definitions of "green projects may...vary depending on sector and geography." The 10 categories of green projects in the $2017 \mathrm{GBP}$ are listed below:

(i) renewable energy (including production, transmission, appliances, and products);

25 The original guidelines were drafted by Bank of America Merrill Lynch, Citigroup, Crédit Agricole, and JPMorgan Chase. These banks had gained expertise in underwriting green bonds, largely for multilateral development banks, which were the largest issuers of green bonds prior to 2014. On 13 January 2014, the GBP's were formally endorsed by 12 investment banks, including two from Japan.

26 The five members are Nikko Asset Management, Development Bank of Japan, Daiwa Capital Markets, Mizuho International, and MUFG Securities. However, this somewhat overstates Asian involvement as it is the European subsidiaries of the three Japan-domiciled investment banks that are members.

27 The seven observers are China Lianche Equator Environmental Impact Assessment, Japan Quality Assurance Organization, Shanghai Clearing House, Shanghai Stock Exchange, Syntao Green Finance, Japan Research Institute, and the Tiajin Green Supply Chain Service Center 
(ii) energy efficiency (such as new and refurbished buildings, energy storage, district heating, smart grids, appliances, and products);

(iii) pollution prevention and control (including wastewater treatment, reduction of air emissions, greenhouse gas control, soil remediation, waste prevention, waste reduction, waste recycling and energy- and emission-efficient waste to energy, value-added products from waste and remanufacturing, and associated environmental monitoring);

(iv) environmentally sustainable management of living natural resources and land use (including environmentally sustainable agriculture, environmentally sustainable animal husbandry, climate smart farm inputs such as biological crop protection or drip-irrigation, environmentally sustainable fishery and aquaculture, environmentally sustainable forestry including afforestation or reforestation, and preservation or restoration of natural landscapes);

(v) terrestrial and aquatic biodiversity conservation (including the protection of coastal, marine, and watershed environments);

(vi) clean transportation (such as electric, hybrid, public, rail, nonmotorized, multimodal transportation, infrastructure for clean energy vehicles, and reduction of harmful emissions);

(vii) sustainable water management (including sustainable infrastructure for clean and/or drinking water, sustainable urban drainage system and river training, and other forms of flood mitigation);

(viii) climate change adaptation (including information support systems such as climate observation and early warning systems); and

(ix) eco-efficient and/or circular-economy-adapted products, production technologies, and processes (such as development and introduction of environmentally friendlier products with an eco-label or environmental certification and resource-efficient packaging and distribution), and green buildings that meet regional, national, or internationally recognized standards or certifications.

Part 2 addresses project evaluation and selection. Issuers of green bonds should describe the decision-making process used to determine the eligibility of specific projects within the bond's green bond framework. External reviews of the green bond framework and the decision-making process from qualified third parties-such as ESG consultancies, accounting firms, or rating agencies - are recommended but not required. External reviews include consultant assessments (known as second opinions), verification and certification, audits, and green bond ratings. The decision-making process should be transparent and external reviews should be disclosed. Investors are encouraged to assess an issuers' overall performance against social, environmental, and governance measures. This is intended to discourage investors from supporting issuers with poor environmental records that are engaging in greenwashing.

Part 3 covers the management of proceeds. Net proceeds of green bonds should be kept separate from other funds available to the issuer to allow the proceeds to be tracked (also known as ring-fencing). While a green bond remains outstanding, "the balance of the tracked proceeds should be periodically adjusted to match allocations to eligible green projects made during the period." Issuers should also state how proceeds that have not yet been allocated to green projects will be managed. The GBP recommend that the 
management of the proceeds be subject to independent monitoring to ensure that the proceeds are being used in accordance with usages described in the offering document.

Part 4 sets out reporting requirements. At least annually, issuers should provide a list of projects funded by the green bond, a description of each project, the amount invested in each project, and the expected environmental impact of each project (ideally in the form of quantitative key performance indicators). "Issuers with the ability to monitor achieved impacts are encouraged to include those in their regulatory reporting." Somewhat controversially, the GBP permit aggregate information to be released if green projects are subject to confidentially agreements or competitive considerations, or if there are too many projects to track.

In February 2015, the Ceres Investor Network on Climate Risk issued a Statement of Investor Expectations for the Green Bond Market. The 27 large investors signing the statement endorsed the GBP, but called for greater clarity in some areas and mandatory actions in others, including the following: ${ }^{28}$

(i) standardized impact reporting against recognized independent standards should be provided annually and made public;

(ii) disclosure of projects that while potentially having a net positive impact on the environment have negative impacts as well (e.g., large-scale hydroelectric dams, nuclear power generation, seawater desalination, and greenhouse gas reductions from coal-fired plants);

(iii) mandated disclosure on use of proceeds:

(a) disclosure of refinancing versus new financing,

(b) disclosure of tracking method for use of proceeds, and

(c) planned disclosure for reporting on environmental impacts;

(iv) issuers should commit to investing the proceeds in a timely fashion appropriate to the tenor of the bond; and

(v) external reviews should be used.

A criticism of the GBP is that they are too vague regarding eligible investments. They do not provide definitive criteria about what is and is not allowed, nor do they make allowances for differences in the "intensity of greenness" among projects. Another concern is that the GBP provide inadequate guidance on environmental performance evaluation and reporting. A third criticism is that most of the principles are recommended but not necessarily required. These concerns were voiced frequently in interviews with officials and market participants in ASEAN+3 countries, who expressed a desire for clearly specified eligibility criteria and reporting obligations.

\section{b. Climate Bond Initiative}

The $\mathrm{CBI}$ is a nongovernment organization representing large investors that aims to promote large-scale investment in projects and activities that will lower carbon emissions and improve the resilience of the global economy to climate change. To this end, the $\mathrm{CBI}$

28 The investors included Allianz, Blackrock, PIMCO, RBC Global Asset Management, and State Street Global Advisors 
has established the Climate Bonds Taxonomy, the CBI Standard, and the Climate Bonds Certification Scheme. The $\mathrm{CBI}$ also works with policy makers to promote the development of green bond markets. The CBI has worked closely with regulators in the PRC to promote the development of the PRC's green bond market. As of 31 March 2017, the CBI was supported by 61 partners plus a handful of philanthropic and public funding agencies. One partner is Nomura Securities.

\section{(i) Climate Bonds Taxonomy}

The Climate Bonds Taxonomy provides eligibility criteria for projects and assets for inclusion in climate bonds. As of 31 March 2017, the taxonomy encompassed 47 sectorspecific areas. Eligibility criteria have been approved in 10 areas and are currently under development in another 16 . In each area, the criteria are prepared by a Technical Working Group composed of experts in the field following the International Social and Environmental Accreditation and Labelling Alliance process for the development of

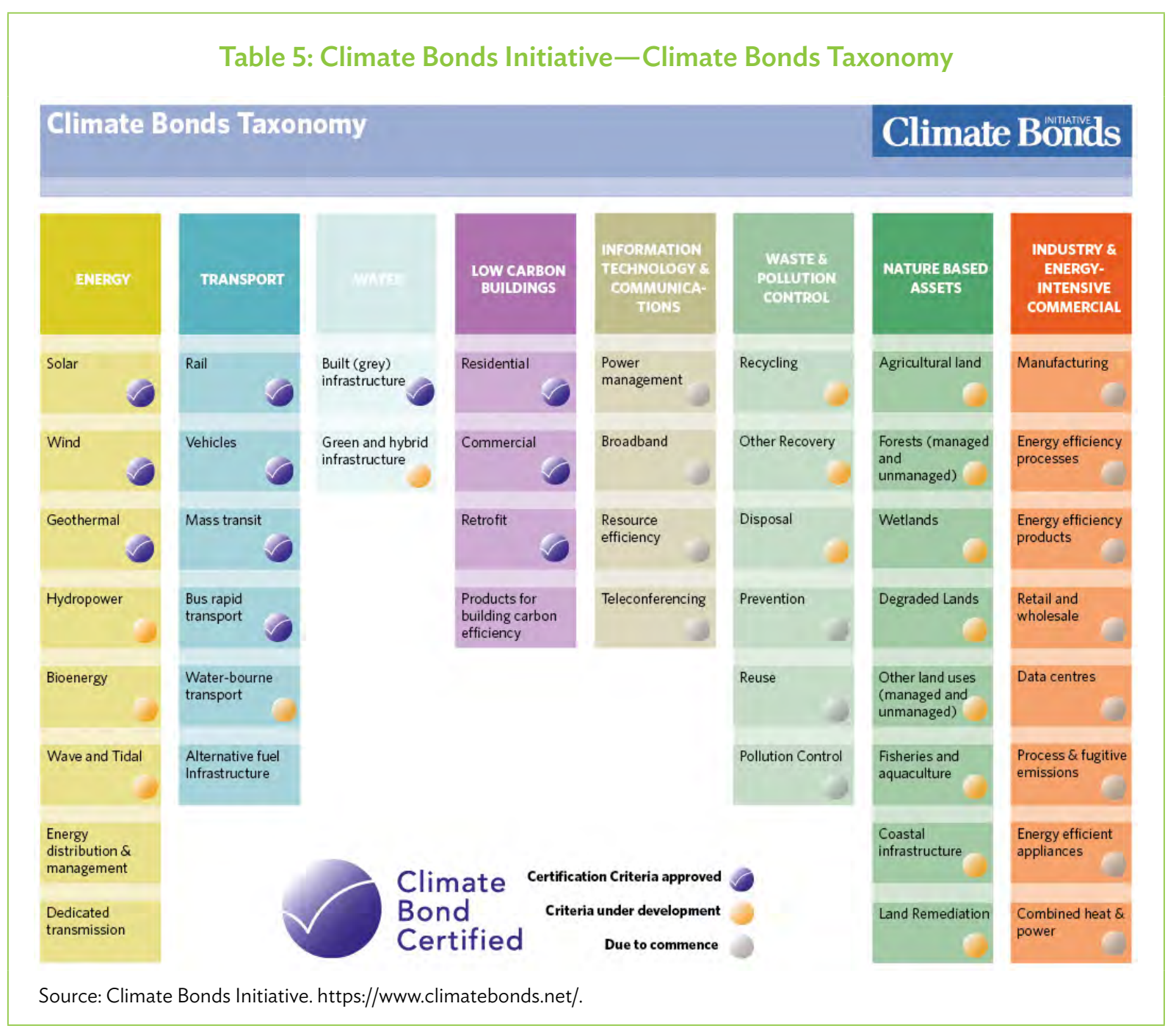


sustainability standards. The entire process is guided by the CBl's Climate Science Advisory Panel. The taxonomy was created to encourage common definitions and enable green bonds to be certified.

\section{(ii) Climate Bonds Standard}

The CBI Standard is a set of environmental standards that set out clear criteria to permit the green credentials of a bond to be verified by external reviewers. For the purposes of the CBI Standard, "green" refers to projects and assets that support "low-carbon industries, technologies, and practices that mitigate green-house gas emissions" and measures to adapt to "the consequences of climate change." The CBI Standard is aligned with the GBP but provides enhanced credibility with investors because of its detailed eligibility criteria and certification scheme. The CBI Standard was first issued in 2010 and has been periodically updated.

The current CBI Standard (version 2.1) is divided into two main parts. The first part sets out pre-issuance requirements, which are designed to ensure that issuers have appropriate internal controls in place prior to issuance and that these controls are sufficiently robust to ensure compliance with the CBI Standard after issuance. The key requirements include the following:

(i) The environmental objectives of the bond shall be stated clearly.

(ii) The issuer shall establish, document, and maintain a decision-making process to determine the eligibility of projects and assets.

(iii) The issuer shall list and assess all projects and assets to determine eligibility.

(iv) Of the net proceeds of the bond issuance, $100 \%$ shall be invested in eligible projects and assets.

(v) The issuer shall keep the proceeds of the bond issuance in a sub-account and track their use.

(vi) The issuer shall disclose how unallocated funds are invested, the verifier selected by the issuer, and whether or not periodic assurance engagements will be undertaken during the term of the bond.

The second part of the CBI Standard deals with post-issuance requirements, which in turn are divided into general requirements, project and asset eligibility requirements, and requirements for specific bond types. The general requirements simply require issuers to meet their obligations under the first part of the CBI Standard. The project and asset eligibility requirements call for compliance with the Climate Bonds Taxonomy and (where available) sector-specific criteria. Requirements for specific bond types address holdings periods, settlement periods, and earmarking. There is also a requirement that net proceeds shall be invested within 24 months of the issuance of the bond (except for project bonds and securitized bonds).

\section{(iii) Climate Bonds Certification Scheme}

The Climate Bonds Certification Scheme sets out a framework to allow external reviewers to provide assurance of conformity with the CBI Standard. The purpose of the certification scheme is to provide investors and other stakeholders with confidence that the proceeds 
of a certified climate bond issue are invested in a manner that mitigates carbon emissions or enables adaption to climate change. The Climate Bonds Certification Scheme is, in effect, a "good housekeeping" seal of approval attesting to the green credentials of a bond. The certification process frees investors of the need to evaluate the green attributes of certified bonds. As of 31 March 2017, 40 bonds with a face value of $\$ 13.2$ billion had been issued as Certified Climate Bonds. Only one is from an issuer in an ASEAN +3 country (AP Renewables, from the Philippines).

Bonds are certified on a pre-issuance and post-issuance basis. Post-issuance certification occurs after the use of the net proceeds of a bond is under way. Periodic post-issuance certification is recommended but not mandatory. Programmatic certification is also available for issuers with a large portfolio of eligible projects and assets planning to issue multiple certified bonds each year. Issuers can seek certification of previously issued bonds.

The certification process begins with an issuer completing the Climate Bonds Information Form and submitting it to the Climate Bonds Standard Secretariat. The issuer must also engage an external reviewer ("verifier"), who is an "independent third-party assurance provider or auditor" that has been approved by the Climate Bonds Standard Board. As of 31 March 2017, 32 firms had been approved as verifiers, including 3 from the PRC. ${ }^{29}$ Once the verifier issues a statement to the issuer confirming conformity with the $\mathrm{CBI}$ Standard, the issuer then applies to the Climate Bonds Standard Board and Secretariat for certification. If approved, the pre-issuance certification is valid for 1 year unless postissuance certification is sought and approved. The post-issuance certification process is similar. Post-issuance certification is valid for the term of the bond, unless the issuer or the Climate Bonds Standard Board finds that the bond or issuer no longer conforms to the CBI Standard.

The Climate Bonds Certification Scheme is seen by several ASEAN+3 market participants and regulators as the gold standard for green bonds. However, some also felt that the scheme is too demanding for issuers and that the higher cost of the certification process and ongoing reporting requirements would discourage issuers from issuing green bonds if they were made mandatory. Another concern is that fewer projects are eligible under the scheme because of its focus on climate change, which is a narrower concept than green projects. Of particular concern to market participants in ASEAN+3 countries is the exclusion of projects improving the efficiency of fossil fuel-based production activities, which are seen in Asia as consistent with the GBP. However, reaction to the 2017 Repsol green bond issue demonstrates that there are differences of opinion among external reviewers, index providers, and investors about whether or not such projects are consistent with the GBP. ${ }^{30}$

29 The three firms from the PRC are China Lianhe Equator, Zhangcai Green Financing Consultants, and SynTao Green Finance. Several companies operating on a global basis, such as the major accounting firms, offer verification services in ASEAN+3 countries, although the assessment teams may be located outside the region.

30 Environmental Finance. 2017. Green Bond Comment: Of Repsol and Reputation. 7 June. 


\section{National Standards}

Through the middle of 2017, financial regulatory authorities in only two countries, the PRC and India, had issued guidance on national green bond standards. Japan's Ministry of the Environment (MOE) has published voluntary guidance for issuers, and cooperating industry associations in Brazil have published voluntary standards. Each of the national standards incorporates many or most elements of the GBP (Table 6), but there are some differences.

\section{Table 6: Green Bond Principles and National Green Bond Guidelines}

\begin{tabular}{|c|c|c|c|c|c|c|}
\hline & GBP 2017 & PRC-NDRC & PRC-PBOC & India-SEBI & Japan-MOE & Brazil $^{*}$ \\
\hline $\begin{array}{l}\text { Use of } \\
\text { proceeds }\end{array}$ & $\begin{array}{l}\text { Full amount for } \\
\text { green projects } \\
\text { or assets }\end{array}$ & $\begin{array}{l}\text { Up to } 50 \% \text { for } \\
\text { non-green uses }\end{array}$ & $\begin{array}{l}\text { Full amount for } \\
\text { green projects } \\
\text { or assets }\end{array}$ & $\begin{array}{l}\text { Full amount for } \\
\text { green projects } \\
\text { or assets }\end{array}$ & $\begin{array}{l}\text { Full amount for } \\
\text { green projects }\end{array}$ & $\begin{array}{l}\text { Full amount for } \\
\text { green projects } \\
\text { or assets }\end{array}$ \\
\hline $\begin{array}{l}\text { Green } \\
\text { definition }\end{array}$ & $\begin{array}{l}\text { Indicative list } \\
\text { of } 10 \text { broad } \\
\text { categories } \\
\text { (generally } \\
\text { aligned } \\
\text { with the } 9 \\
\text { categories } \\
\text { of the } 2016 \\
\text { GBP, with } \\
\text { the addition } \\
\text { of a specific } \\
\text { category for } \\
\text { qualifying green } \\
\text { buildings) }\end{array}$ & $\begin{array}{l}12 \text { project } \\
\text { categories } \\
\text { generally } \\
\text { consistent with } \\
\text { the GBP except } \\
\text { the inclusion } \\
\text { of mitigation } \\
\text { of emissions } \\
\text { from fossil } \\
\text { fuels, use of } \\
\text { nuclear energy, } \\
\text { and large-scale } \\
\text { hydroelectric } \\
\text { power }\end{array}$ & $\begin{array}{l}\text { Green Bond } \\
\text { Catalogue } \\
\text { of } 6 \text { broad } \\
\text { categories, } \\
\text { with } 31 \text { sub- } \\
\text { categories, } \\
\text { generally } \\
\text { consistent with } \\
\text { the GBP with } \\
\text { the exception } \\
\text { of the inclusion } \\
\text { mitigation } \\
\text { of emissions } \\
\text { from fossil fuel } \\
\text { production and } \\
\text { consumption, } \\
\text { and the lack } \\
\text { of emission } \\
\text { intensity } \\
\text { thresholds } \\
\text { for public } \\
\text { transport using } \\
\text { fossil fuels }\end{array}$ & $\begin{array}{l}8 \text { broad } \\
\text { categories } \\
\text { (generally } \\
\text { aligned with } \\
\text { the } 2016 \\
\text { GBP without } \\
\text { a specific } \\
\text { category for } \\
\text { eco-efficient } \\
\text { products, } \\
\text { technologies, } \\
\text { and processes) } \\
\text { plus any other } \\
\text { category } \\
\text { specified by the } \\
\text { SEBI }\end{array}$ & $\begin{array}{l}\text { Indicative list } \\
\text { of } 9 \text { broad } \\
\text { categories } \\
\text { (generally } \\
\text { aligned with } \\
\text { the } 2016 \mathrm{GBP} \text { ) }\end{array}$ & $\begin{array}{l}\text { Indicative list } \\
\text { of } 9 \text { broad } \\
\text { categories } \\
\text { (generally } \\
\text { aligned with } \\
\text { the } 2016 \text { GBP) }\end{array}$ \\
\hline $\begin{array}{l}\text { Management } \\
\text { of proceeds }\end{array}$ & $\begin{array}{l}\text { Specifically } \\
\text { tracked and } \\
\text { reported; } \\
\text { encouraged use } \\
\text { of an auditor or } \\
\text { third party to } \\
\text { verify internal } \\
\text { tracking and } \\
\text { reporting }\end{array}$ & $\begin{array}{l}\text { No specific } \\
\text { requirement }\end{array}$ & $\begin{array}{l}\text { Special } \\
\text { account or } \\
\text { ledger required } \\
\text { for green bond } \\
\text { proceeds }\end{array}$ & $\begin{array}{l}\text { Process for } \\
\text { tracking and } \\
\text { reporting } \\
\text { required; no } \\
\text { requirement for } \\
\text { auditor or other } \\
\text { third-party } \\
\text { verification }\end{array}$ & $\begin{array}{l}\text { Issuer should } \\
\text { have a process } \\
\text { for tracking and } \\
\text { reporting; no } \\
\text { requirement for } \\
\text { auditor or other } \\
\text { third-party } \\
\text { verification }\end{array}$ & $\begin{array}{l}\text { Issuer should } \\
\text { have a process } \\
\text { for tracking } \\
\text { and reporting, } \\
\text { aligned with a } \\
\text { standard such } \\
\text { as the GBP; no } \\
\text { requirement for } \\
\text { auditor or other } \\
\text { third-party } \\
\text { verification }\end{array}$ \\
\hline
\end{tabular}


Table 6 continued

\begin{tabular}{|c|c|c|c|c|c|c|}
\hline & GBP 2017 & PRC-NDRC & PRC-PBOC & India-SEBI & Japan-MOE & Brazil $^{*}$ \\
\hline Reporting & $\begin{array}{l}\text { Disclosure } \\
\text { of use of } \\
\text { proceeds, } \\
\text { updated } \\
\text { annually, } \\
\text { recommend } \\
\text { qualitative, } \\
\text { and (where } \\
\text { possible) } \\
\text { quantitative } \\
\text { indicators of } \\
\text { performance }\end{array}$ & $\begin{array}{l}\text { No specific } \\
\text { requirement }\end{array}$ & $\begin{array}{l}\text { Annual } \\
\text { disclosure } \\
\text { of use of } \\
\text { proceeds, } \\
\text { and annual } \\
\text { reporting to } \\
\text { PBOC }\end{array}$ & $\begin{array}{l}\text { Initial } \\
\text { disclosures } \\
\text { regarding } \\
\text { green bond } \\
\text { framework, } \\
\text { project criteria } \\
\text { and selection; } \\
\text { ongoing annual } \\
\text { and semiannual } \\
\text { reporting } \\
\text { on use of } \\
\text { proceeds, lists } \\
\text { of projects, } \\
\text { and qualitative } \\
\text { and (where } \\
\text { possible) } \\
\text { quantitative } \\
\text { performance } \\
\text { criteria }\end{array}$ & $\begin{array}{l}\text { Prior } \\
\text { disclosure of } \\
\text { environmental } \\
\text { sustainability } \\
\text { objectives } \\
\text { and criteria } \\
\text { for project } \\
\text { selection, } \\
\text { ongoing } \\
\text { reporting (at } \\
\text { least annually) } \\
\text { on use of } \\
\text { proceeds, } \\
\text { and expected } \\
\text { environmental } \\
\text { benefit of each } \\
\text { green project }\end{array}$ & $\begin{array}{l}\text { Prior disclosure } \\
\text { of green bond } \\
\text { framework } \\
\text { aligned with } \\
\text { a standard } \\
\text { such as the } \\
\text { GBP, ongoing } \\
\text { reporting } \\
\text { (at least } \\
\text { annually) on } \\
\text { disbursement } \\
\text { of proceeds, } \\
\text { and preferably } \\
\text { performance } \\
\text { in terms of } \\
\text { environmental } \\
\text { sustainability }\end{array}$ \\
\hline $\begin{array}{l}\text { External } \\
\text { review }\end{array}$ & Encouraged & Not required & $\begin{array}{l}\text { Encouraged } \\
\text { (in practice, } \\
\text { required) }\end{array}$ & Optional & Recommended & $\begin{array}{l}\text { Strongly } \\
\text { recommended }\end{array}$ \\
\hline
\end{tabular}

$\mathrm{GBP}=$ Green Bond Principles, $\mathrm{MOE}=$ Ministry of the Environment, NDRC = National Development and Reform Commission, PBOC = People's Bank of China, PRC = People's Republic of China, SEBI = Securities and Exchange Board of India.

Note: The respective entities in Brazil are the Brazilian Federation of Banks and Brazilian Business Council for Sustainable Development.

Sources: The Green Bond Principles 2016 and 2017; NAFMII-ICMA. 2017. The Practice and Prospects for Green Bond Market Development at Home and Abroad; Ernst and Young; SEBI Circular CIR/MD/DF/51/2017; MOE. 2017. Green Bond Guidelines Summary; Guidelines for Issuing Green Bonds in Brazil 2016.

\section{a. People's Republic of China}

The bond market in the PRC has multiple regulators responsible for the different segments of the market (Table 7). All bond issuance in the PRC requires regulatory approval. Green guidance has been issued by all of the respective regulators. ${ }^{31}$ The guidance issued by the China Banking Regulatory Commission (CBRC), China Securities Regulatory Commission (CSRC), People's Bank of China (PBOC), stock exchanges, and the National Association of Financial Market Institutional Investors (NAFMII) is quite similar, broadly aligned with the GBP, and relies on the Green Bond Endorsed Project Catalogue (Green Bond Catalogue). While the wording does not strictly require it, regulators, other than the National Development and Reform Committee (NDRC), and market participants have interpreted their guidance as requiring a second opinion. The requirements of the NDRC vary from other guidance in the PRC in not recommending an external review and by including a wider range of eligible green projects that do not align with the GBP.

31 The CBRC has not issued guidance specifically with respect to green bonds, but rather more generally established definitions for green credit. Since 2013, it has required reporting by banks on their green financing activities. In December 2014, the CBRC launched a mix of qualitative and quantitative key performance indicators as a guidance tool for self-assessment by banks, which have to be submitted to the CBRC annually. 


\section{Table 7: Bond Market Regulators and Green Bond Guidance in the People's Republic of China}

\begin{tabular}{|c|c|c|c|}
\hline Issuer & Market & Regulators & Green Bond Guidance \\
\hline $\begin{array}{l}\text { Banks and other financial } \\
\text { institutions }{ }^{\mathrm{a}}\end{array}$ & Interbank & $\begin{array}{l}\text { CBRC } \\
\text { PBOC }\end{array}$ & $\begin{array}{l}\text { - Green Credit Guidelines (2012) and } \\
\text { Green Credit Reporting Instructions } \\
\text { (2013) } \\
\text { - Green Finance Bond Announcement } \\
\text { No. } 39 \text { (2015) } \\
\text { - China Green Bond Endorsed Project } \\
\text { Catalogue (Green Finance Committee, } \\
\text { 2015) }\end{array}$ \\
\hline State-owned enterprises & $\begin{array}{l}\text { Interbank } \\
\text { Exchange Listed }\end{array}$ & $\begin{array}{l}\text { NDRC } \\
\text { Stock } \\
\text { Exchanges }\end{array}$ & $\begin{array}{l}\text { - Guidelines for the Issuance of Green } \\
\text { Bonds (2015) } \\
\text { - Shanghai Stock Exchange Notice No. } \\
13 \text { on Pilot Project of Green Corporate } \\
\text { Bonds (2016), Shenzhen Stock } \\
\text { Exchange Notice No. } 206 \text { (2016). }\end{array}$ \\
\hline Nonfinancial enterprises $^{b}$ & Interbank & NAFMII & $\begin{array}{l}\text { - Non-financial Enterprises Green Debt } \\
\text { Financing Instruments Guideline (2017) }\end{array}$ \\
\hline Corporate bonds & Exchange Listed & $\begin{array}{l}\text { CSRC } \\
\text { Stock } \\
\text { Exchanges }\end{array}$ & $\begin{array}{l}\text { - Guidance on the Development of Green } \\
\text { Bonds Announcement No. } 6 \\
\text { - Shanghai Stock Exchange Notice No. } \\
13 \text { on Pilot Project of Green Corporate } \\
\text { Bonds, Shenzhen Stock Exchange } \\
\text { Notice No. 206, both } 2016 .\end{array}$ \\
\hline
\end{tabular}

$\mathrm{CBRC}=$ China Banking Regulatory Commission, $\mathrm{CSRC}=$ China Securities Regulatory Commission, NAFMII = National Association of Financial Market Institutional Investors, NDRC = National Development and Reform Commission, PBOC = People's Bank of China.

a Includes development banks, policy banks, commercial banks, finance companies, and selected other financial institutions.

b Debt financing instruments Include commercial paper, medium-term notes, small and medium-sized enterprise collective notes, and private placements.

Sources: For issuers, markets, and regulators: A. M. Andrews and P. Braginetz. 2015. Local Currency Bonds and Infrastructure Finance in ASEAN+3. Manila: Asian Development Bank; for green bond guidance, announcements, notices, and guidelines issued by the respective authorities as noted.

Market participants have initiated discussions on the potential to harmonize the different green bond guidance in the PRC, however there is no clarity on a timeline for agreement with the NDRC on a single green project catalogue. The current differences between the NDRC and other regulators have not been a major impediment to the growth of the domestic green bond market. While a common definition of green projects would be helpful, investors in the PRC have accepted bonds approved by the NDRC and other regulators as green. There is nothing to preclude an issuer in the PRC from adhering to the GBP or the CBI Standard in addition to national standards if it wished to target international investors. While estimates vary somewhat, it is likely that about two-thirds of green bond issuance in the PRC would meet the GBP standards. ${ }^{32}$

32 Climate Bonds Initiative. 2017. China Green Bond Market 2016. This notes that 65\% of PRC green bond issuance in 2016 would meet global standards. 


\section{b. India}

The Securities and Exchange Board of India (SEBI) published the requirements for green bond issuance in May 2017. The disclosure-based requirements, based on the GBP, apply both at the time of issuance and an ongoing basis to any issuer intending to label bonds as green. By ensuring minimum standards of disclosure, the SEBI facilitates investors making their own determination of whether or not the bond meets their investment criteria. Unlike in the PRC, there is no detailed green project catalogue, but rather broad categories based on the 2016 version of the GBP. The SEBI has the power to deem additional categories of green projects.

\section{c. Japan Ministry of the Environment}

Japan's MOE published in March 2017 green bond guidelines based on the GBP. The guidelines, which include illustrative examples, are voluntary for issuers and other market participants, focusing on green characteristics with the intention of encouraging credible disclosures and consistent assessments by investors and other market participants. This is expected to ensure credibility in the developing green bond market in Japan.

\section{d. Brazilian Federation of Banks and Brazilian Business Council for Sustainable Development}

Two large industry associations produced in 2016 consensus guidelines on issuing green bonds in Brazil. No changes were recommended to existing regulations, but issuers and other market participants were encouraged to adhere to the voluntary guidelines, based on the GBP. The main focus is on pre-issuance preparation and reporting, and ongoing monitoring and reporting, within the context of existing capital markets law and regulations.

\section{Types of Green Bonds}

Green bonds currently exist, or could be created, in all of the varieties seen in general bond issuance. The most common are described below with examples, where possible from ASEAN +3 countries.

\section{General Obligation}

General obligation bonds are the most common type of long-term debt security. The bonds are backed by the full faith and credit of the issuer, with proceeds being designated for specific projects or activities, or designated for general corporate purposes. The vast majority of green bonds are general obligation bonds, with the proceeds designated for eligible green assets or projects.

The first green bond from an issuer in the PRC, Goldwind New Energy, was a general obligation bond. This was not a typical use-of-proceeds green bond, but rather it was issued for general corporate purposes. The bonds, issued through a Hong Kong, China subsidiary, benefited from a second opinion by DNV GL and qualified as green due to the pure play business focus of the company on renewable energy. 


\section{Sukuk}

Sukuk are instruments structured to generate returns to investors similar to that of a bond without infringing on the Islamic law prohibition on earning interest. Sukuk provide a share in the ownership of assets relating to particular projects or activities. Green financing is consistent with the Islamic principle of Maqasid al-Shariah, which relates to protecting and preserving the benefits and interests of society.

Sukuk are well-suited for infrastructure financing as the sharing of risk between project sponsors and investors and the creation of tangible assets that generate revenue align well with the principles of Sharia (Islamic law) financing. With appropriate project selection, dedicated use of proceeds, and suitable monitoring and reporting, green sukuk could play an important role in infrastructure financing. Although little used in most ASEAN+3 jurisdictions, sukuk have been extensively used for project finance in Malaysia. The predominant use in Malaysia has been for fossil fuel power generation and toll roads, but the now well-established approaches to project structures and financing including sukuk could be applied equally well to climate-aligned projects.

Securities Commission Malaysia revised its Islamic Securities Guidelines in 2014 to provide standards for socially responsible investment (SRI), which encompasses green financing. The Malaysian SRI standards provided the basis for the first green sukuk, Green SRI Sukuk Tadau, issued in late July 2017 to finance a large-scale solar plant. ${ }^{33}$

\section{Revenue Bonds}

Revenue bonds are a specific subset of government-sovereign and more typically subsovereign-bonds. They differ from the general obligation bonds typically issued by governments in having the cash flow for debt service tied to the income stream generated by a specific enterprise. They can be considered a type of securitization as they typically are based on a specific tax or an income stream from activities undertaken by, or on behalf of, local governments.

There are no current examples of revenue bonds in ASEAN +3 , and few examples outside of the US. They are commonly used in the US municipal bond market, where they benefit from tax advantages and low issuance costs due to less stringent registration and disclosure requirements than those that apply in the corporate bond market. ${ }^{34}$ Revenue bonds are well suited to green issuance provided that the enterprise providing the underlying revenue stream would qualify as a green activity.

33 The green sukuk issuance in 2012 cited in a number of sources did not actually proceed. These were for projects in Indonesia by an Australian firm, The Solar Guys. They were structured as conventional infrastructure projects, with individual project entities created (SGI-Mitabu), and repayment to come from the cash flow provided by a guaranteed power-purchase agreement. The financing vehicles were incorporated in Malaysia's offshore Labuan market, taking advantage of tax and other incentives, as well as capitalizing on Malaysian expertise in project sukuk. However, the planned 2012 issue did not proceed, and an attempted revival in 2015 similarly did not come to fruition. Renewable Now. 2015. Sukuk sale plan revived for 50-MW solar project in Indonesia-report. 12 February. https://renewablesnow.com/news/sukuk-sale-plan-revived-for-50-mw-solar-project-in-indonesia-report-463044/ (accessed 7 May 2017).

34 A. M. Andrews and P. Braginetz. 2015. Local Currency Bonds and Infrastructure Finance in ASEAN+3. Manila: ADB. 
There are some common variations on plain vanilla revenue bonds that are largely found in the US market but could be used elsewhere. Conduit revenue bonds are issued by a government on behalf of a third party to finance nonprofit and for-profit borrowers such as housing projects and local development corporations. In the US tax-advantaged municipal bond market, conduit revenue bonds can be structured to have the same tax-advantaged status as other municipal bonds - the interest payments are not subject to federal income tax. Some revenue bonds have payment guaranteed by the municipal government in addition to the revenue stream of the enterprise and are known as double-barreled bonds. Each of these might provide vehicles for appropriately structured green financing of climate-aligned government activities.

\section{Project Bonds}

Project bonds are a special type of debt issued to finance all or part of an infrastructure project. The project is established as a stand-alone legal entity, with the cash flow from the project meeting the debt service requirements and providing the return to equity investors. This contrasts with general obligation debt, where the funds are raised for general corporate purposes and repayment relies on the full faith and credit of the borrower.

Project bonds are ideally suited to green labeling as the typical stand-alone legal structure provides assurance that the funds raised will be used for the intended purpose, and readily facilitates external review, monitoring, and reporting. The first green project bonds in ASEAN+3 were issued in 2017 through the Mega Solar Project Bond Trust, sponsored by a major international investment bank to finance renewable energy in Japan.

\section{Asset-Backed Securities}

Asset-backed securities (ABS) are created by pooling a portfolio of similar assets within a special purpose vehicle (SPV), which in turn issues securities. Ownership of the underlying assets is transferred from the originator to the SPV, providing credit risk transfer as well as capital relief for regulated originators. ${ }^{35}$ Claims on the underlying pool of assets provide the cash flow and collateral to protect the ABS investors. The pooling of underlying assets makes $A B S$ well suited to obtaining capital market financing for assets that are too small or lacking in a suitably high credit rating to attract direct investment.

ABS comprised about $6 \%$ of the green bond market at the end of $2016 .{ }^{36}$ Much of this was in the US market, where one government program alone, the Property Assessed Clean Energy (PACE) program, generated more than $\$ 3.4$ billion in loans securitized by private sector providers of financing for approved energy upgrades to residential and commercial properties. ${ }^{37}$

\footnotetext{
Revisions to the Basel capital accord following the global financial crisis require banks originating ABS to retain a significant risk exposure to the securitized assets, which is intended to align originators' interests with those of investors in $A B S$ by ensuring an ongoing interest in the performance of the underlying assets.

36 S. Kidney, D. Giuliani, and B. Sonerud. 2017. Public Sector Agenda for Stimulating Private Market Development in Green Securitisation in Europe. London. Centre for Climate Change Economics and Policy.

37 P. Xu, S. K. Mah, and B. Sandler. 2017. Clearing the Air-Addressing Three Misconceptions of PACE. Morningstar. http:// pacenation.us/wp-content/uploads/2017/03/morningstar-addressing-misconceptions-pace.pdf.
} 
The first green ABS were originated by Toyota Financial Services in March 2014, which was followed by a second issue in June 2016. Since the supply of underlying leases and loans of green vehicles was insufficient to meet demand, conventional auto loans and leases were also included in the securitization pool. Thus, non-green assets have been securitized to provide incremental investment in qualifying green activities. While these issues are sometimes attributed to Japan, Toyota Financial Services is the automaker's US-domiciled financing arm. The first green securitization in ASEAN +3 refinanced existing wind farm assets of PRC-based renewable energy company, Goldwind New Energy, in August 2016.

\section{Covered Bonds}

Covered bonds are obligations issued by financial institutions secured by an underlying pool of dedicated assets, commonly residential mortgages, in addition to a general claim on the assets of the issuer. They are close cousins to ABS, but are issued directly by the bank itself rather than an SPV, with the issuer continuing to be fully exposed to the credit and liquidity risk of the underlying assets as these remain on its balance sheet. When issued pursuant to a specific legislative framework establishing the covered bondholders' priority claim on the cover pool, covered bonds potentially qualify as high-quality liquid assets (HQLA) in the Basel III framework. ${ }^{38}$ European banks make widespread use of covered bonds as funding instruments, accounting for more than three-quarters of the global covered bond market.

There are two potential ways covered bonds can be used in green financing. One is to refinance existing (non-green) assets through the covered bond issuance, using the proceeds for lending to qualifying new green projects. An alternative for a bank or other financial institution with a portfolio of climate-aligned loans, for example, mortgages on Leadership in Energy and Environmental Design-certified buildings, might be to issue green covered bonds secured by an underlying pool of green assets.

The first green covered bonds were issued in 2015 by Berlin Hyp, a German mortgage bank. It has a green bond program encompassing both covered bonds ("green pfandbriefe") and senior unsecured bonds. The proceeds of the covered and senior bonds are used for the financing or refinancing of loans for green buildings. ${ }^{39}$

The only green covered bond to date in ASEAN +3 , issued by the Bank of China in November 2016, would not qualify as such under the Basel III framework. The issue is secured by an underlying pool of climate-aligned bonds held directly on the Bank of China's balance sheet; however, these covered bonds lack a legislative foundation providing clear segregation of the cover pool. In the absence of this specific legal protection for covered-bond holders, these Bank of China bonds would not meet the international HQLA definition, ${ }^{40}$ and may be less

38 Claims on financial institutions are generally excluded from the definition of HQLA on the grounds that, in a crisis, all financial institutions may be under stress and face challenges meeting their obligations. Covered bonds historically have been important funding sources for European banks and their inclusion in the Basel definition of HQLA both supports the mortgage market and helps to meet the demand for HQLA in jurisdictions where the supply of government and highly rated nonfinancial corporation debt may be insufficient to meet banks' liquidity needs.

39 Berlin Hyp. 2017. Green Bond Framework. http://www.green-pfandbrief.com/home\#home1.

40 Basel Committee on Banking Supervision. 2013. Basel III: The Liquidity Coverage Ratio and Liquidity Risk Monitoring Tools; Footnote 20. 
attractive to foreign institutional investors. ${ }^{41}$ Nevertheless, they have been sold to institutional investors and financial institutions that are not HQLA-constrained, thus providing a refinancing vehicle for the Bank of China's previous investment in climate-aligned bonds.

\section{E. Issuers of Green Bonds}

After originating with supranationals, the green bond market has now expanded to include all categories of issuers of conventional bonds, encompassing specialized green instruments in addition to general obligation bonds (Box 1). Examples of many of the combinations of issuer and bond types can already be found in ASEAN +3 despite the youth of the green bond market.

\section{Box 1: Examples of Green Bond Issuers and Bond Types}

\section{General Obligation Bonds}

Sovereign: Poland inaugural sovereign green bond, December 2016

Supranational: Asian Development Bank inaugural green bond, March 2015

Sub-Sovereign and Agency: Export-Import Bank of Korea, inaugural green bond February 2013

Corporate-Financial: Mitsubishi UFG inaugural green bond, September 2016.

Corporate-Nonfinancial: Nomura Research Institute, green tranche of 3rd series unsecured corporate bonds, September 2016

\section{Specialized Instruments}

Sukuk: Green SRI Sukuk Tadau, RM250 million issued July 2017

Asset-Backed Securities: Toyota Financial Services inaugural green asset-backed securities, March 2014

Covered Bonds: Bank of China inaugural covered green bond, November 2016 ${ }^{\mathrm{a}}$

Project Bonds: Canadian Solar Gunma Aramaki Solar Power Plant (Japan) green project bond, April 2017

Revenue Bonds: East Bay Municipal Utility District (California), Green Revenue Bonds, Series 2017A

a Although commonly referred to as green covered bonds, these bonds do not meet the Basel III definition of covered bond due to the absence of a specific legislative framework to protect the claims of bondholders on the cover pool.

Source: Websites of Green Bond Issuers.

\section{Sovereign}

The first sovereign green bond was issued by Poland in December 2016, followed by France in early 2017. The two sovereign issues were much larger than the average green bond issuance. Excluding the very large French green bond, average issue size in the first half of

41 Reuters. 2016. Fitch: Stronger Framework Would Help China Covered Bonds Develop. http://www.reuters.com/article/ idUSFit981357. 
2017 was about $\$ 300$ million, making the Polish issue ( $€ 750$ million) more than twice the average and the French issue ( $€ 7$ billion) more than 20 times larger than average. ${ }^{42}$

Other sovereigns have been reported to be considering green bond issues, but none had come to market through the end of August 2017. A number of countries reportedly considering green issues lack international investment grade credit ratings. In addition to the green benefits, noninvestment grade sovereigns may broaden their investor base by attracting international institutional investors with either green or SRI mandates who would not otherwise consider a high-yield sovereign issue.

\section{Supranational, Sub-Sovereign, and Agency}

The supranational, sub-sovereign, and agency (SSA) sector is a segment of the broader bond market that in 2016 accounted for about $25 \%$ of the gross issuance of green bonds, and somewhat less than that in the first half of $2017 .{ }^{43}$ The segment is highly diverse, including a wide range of issuers with social and public policy mandates. They include MDBs such as the Asian Development Bank (ADB) and government-related entities including development banks, infrastructure developers, social security funds, utilities and infrastructure operators, as well as municipal and provincial or state governments, and local authorities. CBI identifies about 75 US state and local governments, agencies, universities, and hospitals that have collectively issued about $\$ 19$ billion in green bonds. ${ }^{44}$ Activities typically include financing, building, or operating infrastructure, making many SSA issuers a natural fit for green bond issuance.

\section{a. Supranational}

Until 2010, the green bond market was comprised entirely of supranational issues, beginning with the EIB in 2007 and followed in 2008 by the World Bank. The EIB has issued over $\$ 14$ billion in green bonds, making it the largest single green bond issuer, followed by the World Bank, which has issued more than $\$ 10$ billion in green bonds through more than 130 transactions in 18 currencies. ${ }^{45}$ The EIB and World Bank bonds, as with all green bonds issued to date by the other MDBs, are general obligation bonds, with investors being exposed to the AAA credit risk of the MDB and not the underlying projects funded by the proceeds.

ADB launched its green bond program in 2015 with a 10 -year $\$ 500$ million issue. ${ }^{46}$ This was followed in 2016 with a dual tranche (3-year and 10-year) bond raising $\$ 1.3$ billion, which accounted for about $5 \%$ of total SSA issuance in 2016. The proceeds were allocated to a specific sub-portfolio linked to lending operations for eligible projects. Additional green bonds were issued by ADB in August 2017, raising a further $\$ 1.25$ billion. The Green Bonds Newsletter published by ADB and ADB's Annual Report include information on projects by sector, including target impacts, and on committed and allocated amounts.

\footnotetext{
Authors' calculations from CBI data. https:/www.climatebonds.net/cbi/pub/data/bonds (accessed 7 July 2017). OECD. 2017. Mobilizing Bond Markets for a Low Carbon Transition. Paris.

Authors' calculations using CBI data. Climate Bonds Initiative. Labelled green bonds data. https://www.climatebonds .net/cbi/pub/data/bonds (accessed 7 July 2017).

45 World Bank. Green Bond Issuances to Date. http://treasury.worldbank.org/cmd/htm/GreenBondlssuancesToDate .html (accessed 7 May 2017).

46 The CBI database and some other sources list earlier bonds issued by ADB as being green bonds; however, ADB does not consider them to be green bonds.
} 


\section{b. Sub-Sovereign and Agency}

In terms of number of issues, the sub-sovereign and agency sector has been dominated by local governments, largely US, but with a growing number of European cities. US cities accounted for about $70 \%$ of the $\$ 10.5$ billion green bond issuance by municipalities in 2016, with the balance comprised of cities in Australia, Canada, Finland, Mexico, Norway, and Sweden. ${ }^{47}$ Earlier municipal or municipal-related issuers included Paris, Johannesburg, and Transport for London. There has been a barbell effect through the end of June 2017 with respect to amounts issued, with a few larger issues exceeding $\$ 500$ million, such as the Australian state of Queensland and the Canadian province of Ontario, as well as a number of issues of $\$ 100$ million or less (in some cases significantly so) many by municipal governments or local authorities in the US.

There are also examples of sub-sovereign and agency green bond issues in ASEAN+3 (Table 8). The Export-Import Bank of Korea was the first with its inaugural green bond in 2013. This was followed by a second offering in 2016, with the proceeds dedicated to financing low-carbon initiatives, including renewable energy, energy efficiency, and clean water projects. MTR Corporation, the $70 \%$ government-owned operator of the Hong Kong, China mass transit system, is the only nonfinancial government agency in the region to have issued a green bond through the end of June 2017. Its $\$ 600$ million issue in October 2016 was a green tranche of a $\$ 4$ billion debt issuance program, financing operations and upgrades of its low-carbon transit system.

\section{Corporate Bonds}

General obligation corporate bonds, issued by financial and nonfinancial (commercial) corporations, are the most common type of nongovernment bonds. They accounted for

\section{Table 8: Government Agency Green Bond Issues in ASEAN+3}

\begin{tabular}{l|c|c|c}
\hline Issuer & Jurisdiction & Date & $\begin{array}{c}\text { Amount } \\
(\$ \text { million })\end{array}$ \\
\hline China Development Bank & PRC & February 2017 & 500 \\
& & May 2017 & 500 \\
\hline Export-Import Bank of China & PRC & December 2016 & 144 \\
\hline MTR Corporation & Hong Kong, China & October 2016 & 600 \\
\hline Development Bank of Japan & Japan & October 2016 & 500 \\
& & October 2014 & 263 \\
\hline Export-Import Bank of Korea & Republic of Korea & February 2013 & 400 \\
\hline Korea Development Bank & & February 2016 & 500 \\
\hline
\end{tabular}

MTR = Mass Transit Railway, PRC = People's Republic of China.

Note: If the issuance was not in US dollars, the value has been converted from the issuing currency at the exchange rate at the end of 2016.

Source: CBI data. https://www.climatebonds.net/cbi/pub/data/bonds (accessed 7 July 2017). 
about half of all green bond issuance in 2016, and slightly more in the first half of $2017 .{ }^{48}$ While the funds may be raised for specific purposes, repayment is dependent on the general cash flow and credit-worthiness of the issuer.

\section{a. Financial}

Banks were among the early corporate issuers of green bonds, inaugurated by the Bank of America in 2013. Green bonds can be used by banks in two ways: (i) to refinance existing green assets such as loans for qualifying purposes, and (ii) to raise new funds to invest in qualifying projects. This has the potential to be an important source of green financing for infrastructure projects.

Although no comprehensive data are available, a review of green bond issuance by selected banks and nonbank financial issuers for the first half of 2017 suggests that a significant portion of funds raised are used to refinance existing green assets (Table 9). Proceeds from very few financial green bonds appear to be wholly dedicated to financing new projects. When the proceeds are used for refinancing, there is no incremental green financing unless the funds freed up through the green bond issue are also used to finance green assets.

\section{Table 9: Selected Recent Financial Green Bond Issuance}

\begin{tabular}{l|l|l}
\hline $\begin{array}{l}\text { Issuer } \\
\text { Commonwealth Bank of Australia }\end{array}$ & \multicolumn{1}{|c}{ Issue Date } & \multicolumn{1}{c}{ Use of Proceeds } \\
\hline Nordea Bank 2017 & June 2017 & Finance new projects \\
\hline Intesa Sanpaolo SpA & June 2017 & Refinance existing assets or fund new assets \\
\hline Volvofinans & June 2017 & Refinance existing assets \\
\hline $\begin{array}{l}\text { Caisse des Dépôts et } \\
\text { Consignations }\end{array}$ & May 2017 & Refinance existing assets or fund new assets \\
\hline Westpac Banking Corp & May 2017 & Refinance existing assets \\
\hline National Bank of Abu Dhabi & March 2017 & Refinance existing assets or fund new assets \\
\hline
\end{tabular}

Sources: $\mathrm{CBI}$; press releases or investor presentations for individual issues.

Banks in ASEAN have yet to issue green bonds, but there are recent examples in the PRC and Japan. In the Republic of Korea, a nonbank financial firm, Hyundai Capital, issued a green bond in March 2016 to fund purchase-financing for electric and hybrid vehicles. The Agricultural Bank of China issued the first financial green bond in the PRC market in late 2015, followed by about 12 more banks through the middle of 2017. These have included the state-owned policy banks and a range of commercial banks. Sumitomo Mitsui Banking issued the first private sector green bond in Japan in October 2015, raising about $\$ 500$ million to finance solar and other renewable energy projects. ${ }^{49}$ This was followed in September 2016 by the first green bond issued by Mitsubishi UFG.

OECD. 2017. Mobilizing Bond Markets for a Low Carbon Transition. Paris

Nikkei Asian Review. 15 October 2015. SMBC To Become First Megabank to Issue Green Bonds. http://asia.nikkei.com/ Markets/Capital-Markets/SMBC-to-become-first-megabank-to-issue-green-bonds. 


\section{b. Nonfinancial}

Nonfinancial (or commercial) companies accounted for about a quarter of green bond issuance in the first half of 2017, down slightly from their share in 2016.50 This was still significantly higher than in earlier years, reflecting that the green bond market originated with supranationals, followed by banks. Within ASEAN, the first green bond issues were corporates: AP Renewables in the Philippines in February 2016 and CDL Properties in Singapore in April 2017. The first green bond from a PRC issuer was also a corporate: Xinjang Goldwind New Energy (Goldwind) in August 2015.

\section{F. Issuing a Green Bond}

Issuing a green bond to fund environmentally beneficial projects or assets is similar to issuing a conventional bond. Issuers must determine the size, currency, tenor, coupon, and legal structure of the bond. They must select an underwriter, decide if the bond should have its creditworthiness rated (and if so by whom), and determine in which jurisdictions the bond will be offered and whether or not it should be listed on a securities exchange. There are additional steps to issuing a green bond. This section outlines the steps that issuers should take. ${ }^{51}$

Step 1: Internal decision to issue a green bond. There are benefits and costs to issuing a green bond over a conventional bond (sections $B$ and $G$ of this chapter). Treasury professionals normally make the decision about what type of bond to issue, but other stakeholders may be involved in the case of green bonds. For corporations, the decision may be influenced by corporate affairs or sustainability departments, especially if a key motivating factor for issuing a green bond is to burnish a company's environmental credentials. Treasury officials at public sector issuers need to be aware of policy directives and political imperatives setting out priorities for green bond issuance. The decision to issue a green bond over a conventional bond should be backed by cost-benefit analysis to the extent possible. Benefits such as a wider investor base or a better environmental image may be difficult to quantify in dollar terms. Ideally, nonquantifiable benefits would be linked to performance measures that would indicate if purported benefits are materializing.

Step 2: Prepare a green bond framework. The green bond framework is a governance document that specifies how the proceeds will be used and what reporting will be provided to investors. At its core are the four major parts of the GBP. The types of activities covered by a green bond framework are listed in Table 10.

When designing a green bond framework, issuers must trade-off specificity, stringency, and transparency with flexibility and lower post-issuance costs. Tighter eligibility requirements, more thorough selection processes, and more comprehensive and frequent public reporting lead to higher levels of greenness. They also raise issuance costs. A challenge for issuers

50 Authors' calculations using CBI data. Climate Bonds Initiative. Labelled green bonds data. https://www.climatebonds .net/cbi/pub/data/bonds (accessed 7 July 2017).

51 This section assumes that issuers have a ready supply of potentially eligible green projects and assets that they wish to finance. 


\section{Table 10: Green Bond Framework}

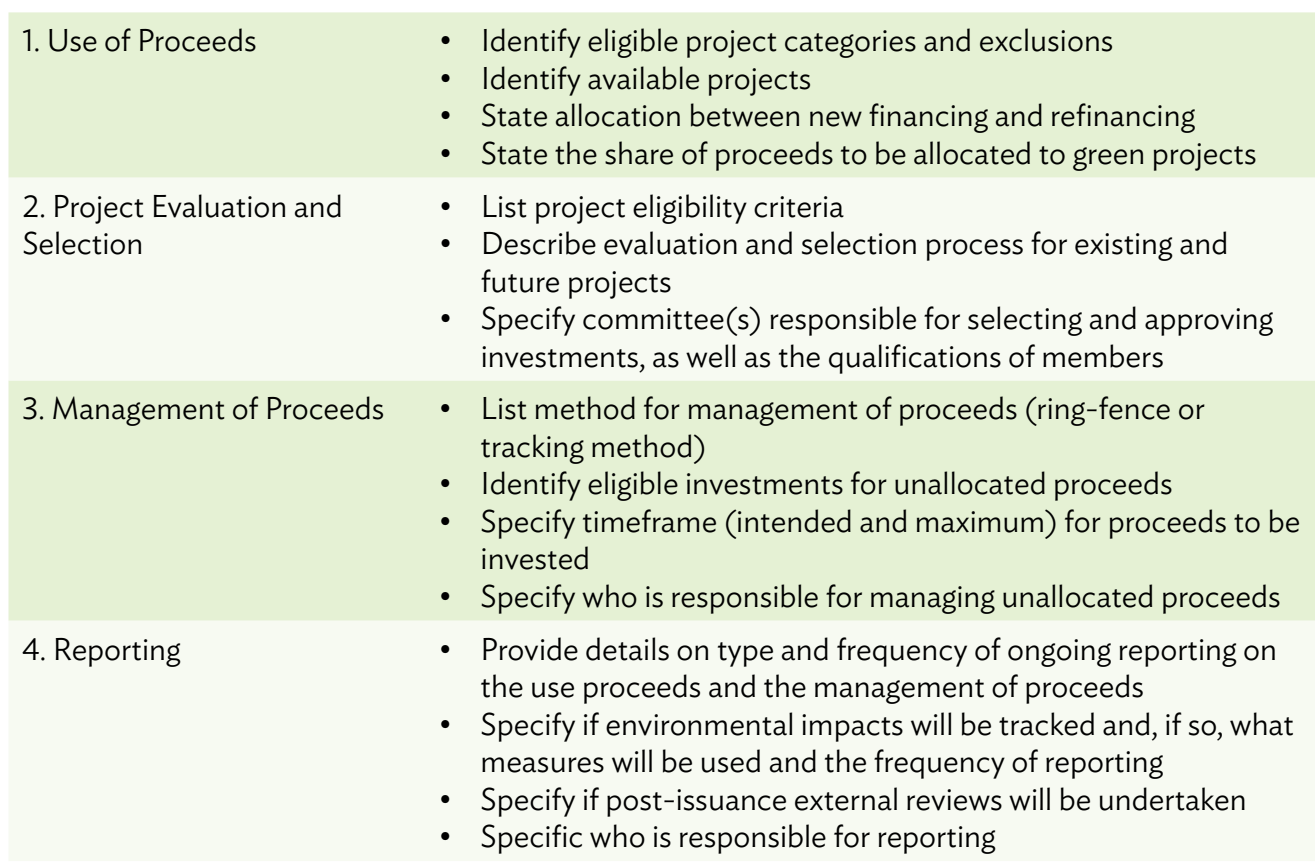

Source: Authors' summary from green bond issuance documents.

is that industry norms regarding the requirements for issuing a credible green bond are becoming more stringent as the market matures.

Step 3: Hire an external reviewer. External reviewers provide second opinions on the conformity of an issuer's green bond framework with the GBP or third-party verification of compliance with national or international standards (e.g., CBI Standard). External reviews differ from ratings of creditworthiness, although some credit rating agencies also perform external reviews. In the case of second opinions, the process involves meeting with the issuer, evaluating the green bond framework, requesting and reviewing supporting documentation, issuing a draft opinion, incorporating comments from the issuer, and finalizing an opinion. In many cases, the external reviewer also works with the issuer to develop their green bond framework, particularly if this is their first green bond issue. The third-party verification process is similar. Another option is an audit. Audit firms conduct pre-issuance assessments of the processes and systems for financing eligible projects and assets. The focus here is on compliance with stated processes, such as green loan approval and investor reporting, and not the validity of the green bond framework. The audit firm will issue a letter to management offering an opinion on the veracity of the process. Section $\mathrm{H}$ below provides details on the work of external reviewers. Criteria for selecting external reviewers include experience and depth of team, price, timeliness, and credibility with investors.

Step 4: Prepare documentation. The issuer (working with an underwriter) prepares offering documentation that includes details on the use of proceeds and on the nature of future reporting. The offering document will also include other information normally found in the offering documents of conventional bonds that address the creditworthiness of the 
issuer and the structure of the bond. The information to be provided in offering documents is normally prescribed by the securities commissions of the jurisdictions where the bond is to be sold and will differ depending on whether the issue is offered on a private basis reserved for institutional investors or is being made more widely available to retail investors. Specific information regarding the green use of proceeds, segregation of funds, and ongoing reporting can be accommodated within general disclosure requirements, or as in the case of India, may be specifically prescribed for green bonds.

Step 5: Green bond roadshow. Issuers prepare an investor presentation, identify potential investors, and decide what cities to visit. Investors with responsible investment mandates are often targeted for green bond issues. Potential investors are asked about their interest in the issue, which could lead to modifications of the terms of the issue if there is insufficient demand.

Step 6: Launch and price green bond. Once the roadshow is complete and it has been determined that there is sufficient demand for the issue to go ahead, the final price and amount is set. If the issue is oversubscribed, as has frequently been the case for green bonds, then the underwriter determines allocations.

The greenness of the issuer may be contentious. Investors are mostly focused on the greenness of the project or assets being funded by the proceeds from the green bond, however, issuers from resource extraction sectors, and companies with a history of poor environmental stewardship, are likely to face greater scrutiny. Investors with responsible investment mandates have indicated that they are less likely to buy green bonds issued by companies with low ESG ratings.

Green bonds take about 4 weeks to 8 weeks to issue after the decision has been made to proceed, with this time line running concurrently with the general bond issuance process in a jurisdiction with a prospectus review or other submission or approval requirements. The range is due in large part to the amount of time for the external reviewer to complete their work. Most want 4 weeks to 5 weeks to complete their work, but it can be done more quickly if requested by the issuer. Subsequent issues can be evaluated more quickly due to the issuer's familiarity with the process and the external reviewer's familiarity with the issuer. The period of time to issue a green bond is typically longer than a conventional bond when an external reviewer is used. Not all green bonds use an external reviewer.

\section{G. Cost of Issuing a Green Bond}

\section{Administrative Costs}

Issuing green bonds result in higher administrative costs to issuers than conventional bonds. These additional costs are mostly borne in the first year, though there is an ongoing component to them as well. Table 11 provides estimates of the types of incremental costs issuers face. Internal costs are the cost of staff time to develop the green bond framework, manage the allocation of proceeds, and provide reporting. These costs are highest for issuers with comprehensive green bond frameworks and reporting schemes, multiple projects and assets funded by the green bond, and for companies located in high-wage 
jurisdictions. External costs are the fees paid to professional services firms. The largest variable cost is external reviewers.

The estimates provided in Table 11 do not include the cost of providing ongoing reporting on the actual environmental benefits provided by projects funded with the proceeds of green bonds. This is known as impact reporting. At present, less than half of issuers provide impact reporting and, among those that do, the quality is often low. Relevant benchmarks may be missing, there may be a mismatch between the life of the bond and the life of the asset, reported metrics may not be relevant, and there is little consistency across issuers. ${ }^{52}$ Nevertheless, large investors with responsible investing mandates are pushing for greater impact reporting from issuers. Because impact reporting has not yet become an industry norm (i.e., many investors do not require it) and because the potential cost of providing this information would vary tremendously among issuers, it is not included in Table 11. However, issuers should be aware of the growing demand for impact reporting and the cost of providing it.

\section{Table 11: Incremental Cost of Green Bond Issuance}

$(\$)$

\begin{tabular}{l|c|c|c}
\hline \multicolumn{2}{l|}{$\begin{array}{l}\text { Administrative Costs } \\
\text { Internal costs (e.g., treasury, corporate affairs, and sustainability departments) }\end{array}$} & \multicolumn{1}{c}{ Ongoing } \\
\hline \multicolumn{1}{|c|}{ Green bond framework } & $5,000-15,000$ & n.a. & n.a. \\
\hline Selection process & n.a. & $2,000-5,000$ & n.a. \\
\hline Management of proceeds & n.a. & $1,000-2,000$ & n.a. \\
\hline Reporting & n.a. & $2,000-10,000$ & $2,000-10,000$ \\
\hline External & & & \\
\hline Legal & $2,000-5,000$ & n.a. & n.a. \\
\hline External review & $15,000-50,000$ & $0-10,000$ & $0-10,000$ \\
\hline Total & $22,000-70,000$ & $5,000-27,000$ & $2,000-20,000$ \\
\hline
\end{tabular}

n.a. $=$ not applicable.

Note: Estimates assume that the net proceeds from the green bond are fully deployed after 1 year.

Source: Authors' estimates.

Table 12 expresses these costs in terms of annual basis points (bps) for a 5 -year and 10-year bond of five different issue sizes. There are two observations to note. First, the annual incremental cost of green bonds is low, in most cases less than 2 bps. However, because they are largely fixed costs, they increase dramatically as issue size drops below $\$ 100$ million. Second, annual incremental costs decline rapidly with issue size and tenor.

An important caveat to these estimates is that there are economies of scale for entities issuing multiple green bonds. Issuers commented that there is a significant learning curve

52 CBI. 2017. Post Issuance Reporting in the Green Bond Market. June. 


\section{Table 12: Annual Incremental Cost of Green Bonds (bps)}

\begin{tabular}{c|c|c|c|c|c} 
& \multicolumn{1}{|c|}{$\$ 50$ million } & $\$ 100$ million & $\$ 200$ million & $\$ 500$ million & $\$ 1$ billion \\
\hline 5 -year & & & & & \\
\hline Low & 1.4 & 0.7 & 0.4 & 0.1 & 0.1 \\
\hline High & 7.1 & 3.5 & 1.8 & 0.7 & 0.4 \\
\hline 10 -year & & & & & \\
\hline Low & 0.9 & 0.5 & 0.2 & 0.1 & 0.1 \\
\hline High & 5.5 & 2.8 & 1.4 & 0.6 & 0.3 \\
\hline
\end{tabular}

bps = basis points

Source: Authors' estimates based on Table 11.

associated with their first green bond issue. Thus, regular issuers of green bonds benefit from productivity gains as their staff gain expertise in the management of the green bond process, as well as from the ability to spread some of these costs over multiple bond issues.

Issuers in ASEAN+3 countries expressed some concern over the potentially rising cost of post-issuance reporting. Three years ago, post-issuance reporting focused largely on confirming that proceeds from the green bond issue were used as promised. Increasingly, investors want detailed impact reporting. As noted, depending on the number of projects being funded by the green bond and the capabilities of the issuer to measure ongoing environmental impacts, this could greatly add to the cost of green bonds issuance. One issuer of a foreign currency green bond remarked that they were holding off on additional green bond issues until they had a better sense of what these added costs might be. This is especially challenging for banks since they do not have operational control of the projects they are funding and, thus, are dependent on the operators to provide the necessary information.

\section{Pricing}

Are green bonds priced at a premium (higher price, lower yield) or a discount (lower price, higher yield) to conventional bonds? A premium means that investors accept a lower yield to hold green bonds, which benefits issuers. A discount means that investors demand a higher yield to hold green bonds, which hurts issuers. A premium or discount may exist at the time of issue or in secondary markets. This section first reviews the theoretical arguments as to why green bonds should be priced at a premium, discount, or on par with conventional bonds, and then summarizes empirical studies examining this question. This latter work has largely focused on matched comparisons of green and conventional bonds by the same issuer.

Fundamentally, green bonds should trade on par with conventional bonds when they are from the same issuer, have the same financial characteristics, and are issued on a pari passu basis (i.e., they are treated equally in the case of default). This is the case for most green bonds, which have been issued as general obligation bonds. Thus, the creditworthiness of most green bonds is based on the issuer's overall ability to meet its debt obligations 
and not on the financial viability of the projects and assets funded by the green bond's proceeds. ${ }^{53}$ Under these circumstances, pricing differences would be due to technical or perceptual factors.

Green bonds could trade at a premium (lower yield) if there were greater demand for them than conventional bonds. This would happen if investors did not see green and conventional bonds as direct substitutes and the relative demand for green bonds exceeds that for conventional bonds. Investors may be willing to pay a premium for green bonds for two reasons. One is that they believe green bonds are less risky due to lower environmental risks and that these lower risks are not captured by the bond's credit rating. ${ }^{54}$ However, this argument can be challenged on the grounds that most green bonds have been issued as general obligation bonds and thus they have identical creditworthiness to conventional bonds from the same issuer. Due to the infancy of the green bond market, there is also no empirical evidence yet to show that green bonds have lower default rates.

The second reason investors may be willing to accept a lower yield is that they derive additional value from green bonds apart from their financial returns. Such ancillary benefits depend on the type of investor but could include (i) higher CSR or ESG ratings, (ii) closer alignment with responsible investment mandates, and (iii) explicit consideration of the bond's "environmental return." 55 However, these benefits are of little value to conventional investors, who are also significant holders of green bonds. Green bonds could only have a lower yield if all the bonds were held by responsible investors. Otherwise, traditional investors would sell their green bonds to responsible investors who would be willing to pay a higher price.

Green bonds could trade at a discount (higher yield) due to technical and perceptual factors. One factor is issue size. If green bond issues are smaller than conventional issues, they will tend to be less liquid. ${ }^{56}$ Further, market participants have suggested that green bonds are more likely to be held on a buy-and-hold basis than conventional bonds. Investors demand a higher yield to compensate for less liquidity. Another factor that may lead to a discount is event risk. Green bonds carry with them the promise of environmental benefits. Such claims are sometimes challenged. If investors worry that a future event could undermine a bond's green claim, they will want a higher yield to compensate for that risk. If this is a meaningful concern, this discount should decline as a bond's greenness increases.

53 There are exceptions such as ABS, covered bonds, and pure green projects and companies (e.g., solar energy producers). Some have suggested that these bonds may be priced at a premium (lower yield) relative to conventional bonds because they have lower environmental risk.

54 There is some evidence that sustainability criteria can improve credit rating scores. For instance, O. Weber, R. Scholz, and G. Michalik. 2010. Incorporating Sustainability Criteria in Credit Risk Management. Business Strategy and the Environment. 19 (2010). pp. 39-50.

55 In a novel analysis, BMO Capital Markets estimated that the "environmental return" from a green bond issued by the EIB was 11 bps. Their calculation was based on the value of carbon dioxide emission reductions ( $\$ 10$ per ton) and the volume of carbon dioxide emission reductions brought about by the projects funded by the ElB green bond. BMO Capital Markets. 2015. Fixed Income Strategy Market Update. 18 December. pp. 9-10.

56 Small issue sizes tend to be less liquid because (i) there are fewer bonds to trade, (ii) they are less likely to be included in an index, and (iii) they are less attractive to very large investors since they are unable to take a meaningful position relative to the size of their portfolio. In addition, market participants have suggested that investors with responsible investment mandates are more likely to hold green bonds to maturity than conventional bonds. 
Some recent empirical work suggests that green bonds are priced at a premium relative to conventional bonds (Table 13). Five of six studies found that the yields on green bonds at issuance or in secondary markets were lower than comparable conventional bonds. However, this body of work is more suggestive than conclusive because comparisons between the yields on green and conventional bonds are difficult due to limited and noncomparable data. The validity of these types of studies will improve as green bond markets mature.

\section{Table 13: Summary of Studies on Green Bond Pricing}

\begin{tabular}{|c|c|c|}
\hline Study & Finding on Green Bonds & Methodology and Comments \\
\hline Barclays (2015) & Premium (16.7 bps) & $\begin{array}{l}\text { Regression on credit spread that decomposes } \\
\text { option-adjusted spread into common risk factors } \\
\text { Premium was larger in } 2015 \text { than } 2014\end{array}$ \\
\hline $\mathrm{BMO}(2016)$ & Premium (2.2 bps) & $\begin{array}{l}\text { Matched comparisons } \\
\text { All US dollar SSA bonds since } 2013 \text { with an issue } \\
\text { size of } \$ 500 \text { million or more } \\
24 \text { bonds in primary market and } 14 \text { in secondary } \\
\text { market } \\
\text { Premium in } 2016 \text { only; a discount of } 1.0 \text { bps- } \\
2.0 \text { bps in } 2013-2015\end{array}$ \\
\hline CSDC (2016) & Premium & $\begin{array}{l}\text { Comparison of green bonds in the People's } \\
\text { Republic of China with conventional bonds of the } \\
\text { same rating and tenor } \\
\text { No information disclosed on how this } \\
\text { comparison was made }\end{array}$ \\
\hline GRESB (2015) & Discount & $\begin{array}{l}\text { Among three comparable pairs from the same } \\
\text { issuer, coupons on green bonds were higher than } \\
\text { on non-green bonds } \\
\text { Yields for six of seven real estate corporations' } \\
\text { green bonds were above the issuer's conventional } \\
\text { bond yield curve }\end{array}$ \\
\hline Zerbib (2017) & Premium (2bps-9 bps) & $\begin{array}{l}\text { Matched comparisons with differences in } \\
\text { liquidity controlled for by using a fixed-effect } \\
\text { regression model } \\
135 \text { investment-grade bonds denominated in US } \\
\text { dollars and euros }\end{array}$ \\
\hline $\begin{array}{l}\text { Ehlers and } \\
\text { Packer (2017) }\end{array}$ & Premium (18 bps) & $\begin{array}{l}\text { Matched comparison of } 21 \text { green bonds issued } \\
\text { from } 2014 \text { to } 2017 \\
\text { Limited to general obligation bonds with pari } \\
\text { passu ranking } \\
\text { Standard deviation of } 27 \text { bps, with five issues } \\
\text { priced above matched conventional bond }\end{array}$ \\
\hline
\end{tabular}

$\mathrm{BMO}=$ Bank of Montreal, $\mathrm{CBI}=$ Climate Bonds Initiative, $\mathrm{CSDC}=$ China Government Securities Depository Trust and Clearing Company, GRESB = Global Real Estate Sustainability Benchmark, SSA = supranational, sub-sovereign, and agency, US = United States.

Note: Results of the China Government Securities Depository Trust and Clearing Company (CSDC) study are reported in CBI. 2017. China Green Bond Markets 2016. p. 14.

Sources: R. Preclaw and A. Bakshi. 2015. The Cost of Being Green. Barclays Credit Research. 18 September; BMO Capital Markets. 2016. Fixed Income Strategy Market Update. 16 December; S. Anzinger. 2016. Green Bonds: Costs and Benefits of Issuance and Investments. GRESB Green Bond Working Group. January; O. D. Zerbib. The Green Bond Premium. Unpublished; and T. Ehlers and F. Packer. 2017. Green Bond Finance and Certification. Bank for International Settlements Quarterly Review. September. pp. 89-103. 
Other empirical evidence to suggest a premium for green bonds is less persuasive. High oversubscription rates (often three to four times) and tighter-than-expected pricing for primary offerings (10 bps-15bps) have been presented as evidence for premium pricing, but conventional bonds display similar traits. ${ }^{57}$ Other studies have compared the yield of green and conventional bonds from the same issuer and have not found systematic differences. ${ }^{58}$ Another study found that the risk-adjusted return of hedge green bond indices are similar to comparable conventional global bond indices, while unhedged green bond indices underperformed their conventional counterparts. ${ }^{59}$ These findings are consistent with private discussions with North American fixed income managers, who observed that green bonds generally traded on par in secondary markets with conventional bonds from the same issuer. ${ }^{60}$

Almost all market participants in ASEAN+3 countries with direct experience with green bond issuance interviewed as part of the fieldwork for this report said that green and conventional bonds from the same issuer generally traded on par. A few market participants said that on some occasions green bonds were issued at a small premium (less than 5 bps), but this tended to be for an issuers' first issue in new markets. One underwriter said they had aggressively priced new green bond issues to establish a foothold in a new and emerging market, and that they leaned heavily on investors to accept a lower yield by promising them better allocations of in-demand securities in the future. Other underwriters acknowledged that this practice was not unusual.

In sum, while there is some evidence that investors have at times paid a premium to hold green bonds, this appears to be the result of idiosyncratic rather than systematic factors. Further, such anomalies are unlikely to persist. If the green bond premium is due to insufficient supply, issuers will fill this gap to secure lower cost funding. ${ }^{61}$ The gap may not close entirely since there are higher incremental costs to issuing green bonds, although these costs are small ( 1 bps-2bps) and decline with issue size and with the number of green bonds that have been issued by an entity. There are also limits on how much extra investors are willing to pay to hold green bonds. Anecdotal comments from responsible investors - those who are most likely to be willing to pay a premium to hold green bonds - suggest that the size of the premium that they are willing to pay is very small. Most responsible investors said that green bonds must offer returns comparable to conventional bonds to be considered for inclusion in their portfolios.

\section{H. External Reviewers}

External reviews by independent third parties are a critical element of green bond issuance. They supplement an issuer's own disclosures and provide, in effect, a "good housekeeping"

57 CBI. 2017. Green Bond Pricing in the Primary Market, January 2016-March 2017. June. This study offers two other indicators of a green premium - the tightening of green bond spreads 7 days and 28 days after issuance in absolute terms and relative to a corresponding index-but neither offer comparable information on conventional bonds, which is necessary to gauge the significance of these findings.

58 Footnote 62, pp. 10-12; UBS. 2017. Fixed Income: Exploring Green Bonds. 8 August. pp. 2-3; and Table 1 in a Natixis study reported in S\&P Global. 2017. Beyond Green Bonds: Sustainable Finance Comes of Age. 26 April. pp. 5-6.

59 T. Ehlers and F. Packer. 2017. Green Bond Finance and Certification. Bank for International Settlements Quarterly Review. September. pp. 89-104

60 These observations are taken from interviews with six fixed income managers in May-June 2017.

${ }_{61}$ This assumes that green bond projects and assets are available for funding by green bonds. 
seal of approval to investors that proceeds from the issue will fund environmentally beneficial projects and assets. This simplifies the process for investors to identify credible green bonds. Like credit ratings, external reviews are paid for by the issuer. External reviews are not legally required by securities regulators, although in the PRC all issuers other than those overseen by the NDRC interpret the encouragement to use an external review as mandatory. Industry best practice is to engage an external reviewer and investors with responsible investment mandates consider them essential. External reviews are required by the CBI Standard but are only recommended by the GBP. The four largest securities exchanges with green bond listings include external reviews as a listing requirement.

There are four types of external reviews: second opinions, certification and verification, assurance, and ratings. Each can be done on a pre- or post-issuance basis. There are important differences in terms of what each review covers, but there are also significant overlaps. Firms providing external reviews may offer two or more types of reviews. External review reports are usually publicly disclosed. Each year, about $50 \%-70 \%$ of self-labeled green bonds engage an external reviewer. ${ }^{62}$ Second opinions are the most common type of external review.

In 2016, 310 self-labeled green bonds were issued according to CBI data. External reviews were provided for about two-thirds of them (Table 14).

\section{Table 14: External Reviews of Green Bonds in 2016 (Global)}

\begin{tabular}{l|c}
\hline Type of External Review & Share (\%) \\
\hline None & 33.3 \\
\hline Second opinion and certification & 54.2 \\
\hline Assurance & 11.5 \\
\hline Ratings & 1.0 \\
\hline
\end{tabular}

Source: Authors' calculations based on number of issues using CBI data. Climate Bonds Initiative. Labelled green bonds data. https://www.climatebonds.net/cbi/pub/data/bonds (accessed 7 July 2017).

In 2016, 69 self-labeled green bonds were issued in ASEAN+3 countries, with 62 of them from issuers based in the PRC. In the PRC, assurances are relied on more heavily than second opinions and certifications (Table 15). All seven of the non-PRC ASEAN+3 issues utilized a second opinion reviewer.

\section{Second Opinion}

A second opinion is an assessment by an independent firm with environmental expertise as to the credibility of an issuer's green bond framework. They provide support for the issuer's claim that the bond will have positive environmental impacts, but they do not provide independent measurement of the expected or actual benefits. Second opinions 


\section{Table 15: External Reviews of People's Republic of China Green Bonds in 2016}

\begin{tabular}{l|c}
\hline Type of External Review & Share (\%) \\
\hline None & 37.9 \\
\hline Second opinion and certification & 18.2 \\
\hline Assurance & 40.9 \\
\hline Ratings & 3.0 \\
\hline
\end{tabular}

Source: Authors' calculations based on number of issues using CBI data. Climate Bonds Initiative. Labelled green bonds data. https://www.climatebonds.net/cbi/pub/data/bonds (accessed 7 July 2017).

are conducted prior to issuance, but issuers may also engage them after a bond has been issued to confirm that the proceeds have been used, and that reporting has been provided, in conformity with the green bond framework.

While the evaluation processes differ among firms, the core elements of them all center on the GBP's four pillars: (i) use of proceeds, (ii) project selection, (iii) management of proceeds, and (iv) reporting. After reviewing an issuer's green bond framework and supporting documentation, the external reviewer issues a report offering an opinion as to the bond's green credentials. Some firms offer binary opinions (i.e., the bond does or does not meet the current best practices for green bonds), while others offer granular assessments as to the greenness of a bond. In the latter category, for instance, the Centre for International Climate and Environmental Research (CICERO) categorizes its opinion as dark green, medium green, or light green.

Second opinion firms are often hired by issuers to help them develop their green bond framework. This has raised concerns about potential conflicts of interest because the firm is essentially offering an opinion on its own work. Second opinion firms respond that, in practice, this is no different than assessing a green bond framework developed by the issuer, making suggestions on how it could be improved, and then offering a positive second opinion if the requested changes are adopted.

Table 16 profiles the major firms providing second opinions. The cost of obtaining a second opinion ranges from $\$ 15,000$ to $\$ 50,000$. Factors that affect the price include time to complete work, scope of engagement, location of the issuer, and previous work for the issuer.

Several domestic firms offer second opinions in the PRC. Syntao Green Finance is a Beijing-based consultancy promoting sustainable finance in the PRC. It is a division of Syntao, a leading provider of services in support of CSR and responsible investment. China Energy Conservation and Environmental Protection (CECEP) Consulting offers a variety of sustainable development services. It is a division of the CECEP Group, a large industrial company with multiple divisions and subsidiaries. Others include Zhongcai Financing Consultants and China Lianhe Equator. In addition, the local offices of the global accounting firms offer second opinions (e.g., EY, Deloitte, and KPMG). 


\section{Table 16: Major Second Opinion Firms}

\begin{tabular}{|c|c|c|c|}
\hline Firm & Share $^{\mathrm{a}}(\%)$ & Evaluation Process & Sample Clients \\
\hline CICERO & 44.4 & $\begin{array}{l}\text { - Shades of green methodology (dark } \\
\text { green, medium green, or light green) and } \\
\text { alignment with GBP } \\
\text { - Analysis of procedures, monitoring and } \\
\text { verification, room for subjective analysis, } \\
\text { possibility of external effects of projects, } \\
\text { rebound effects and transparency }\end{array}$ & $\begin{array}{ll}\text { - } & \text { HSBC } \\
\text { - } & \text { KEXIM } \\
\text { - } & \text { ADB }\end{array}$ \\
\hline Sustainalytics & 32.0 & $\begin{array}{l}\text { - } \text { Alignment with industry practices } \\
\text { - Evaluation of eligibility criteria } \\
\text { - Evaluation of management of proceeds } \\
\text { - Evaluation of green bond reporting } \\
\text { capabilities }\end{array}$ & $\begin{array}{l}\text { - Development } \\
\text { Bank of Japan } \\
\text { - CDL } \\
\text { - } \text { DBS }\end{array}$ \\
\hline Oekom & 6.5 & $\begin{array}{l}\text { - Verification of alignment with GBP } \\
\text { - Definition of green bond verification } \\
\text { - Verification of fund allocation and use of } \\
\text { proceeds sustainability quality } \\
\text { - Assessment of issuers sustainability } \\
\text { performance (using Oekom's ESG } \\
\text { ratings) }\end{array}$ & $\begin{array}{ll}\text { - } & \text { ElB } \\
\text { - } & \text { World Bank } \\
& \text { ABM AMRO }\end{array}$ \\
\hline DNV GL & 6.5 & $\begin{array}{l}\text { - Verification of alignment with GBP } \\
\text { - Verification of definition of use of } \\
\text { proceeds } \\
\text { - Verification of project evaluation and } \\
\text { selection method } \\
\text { - Verification of monitoring and tracking } \\
\text { capabilities } \\
\text { - Verification of green bond reporting } \\
\text { capabilities }\end{array}$ & $\begin{array}{l}\text { - AP Renewables } \\
\text { - Development } \\
\text { Bank of Japan } \\
\text { - NAB }\end{array}$ \\
\hline VIGEO & 4.7 & $\begin{array}{l}\text { - ESG evaluation of issuer } \\
\text { - Analysis of green bond framework and } \\
\text { projects } \\
\text { - Analysis of reporting indicators }\end{array}$ & $\begin{array}{ll}\text { - } & \text { EIB } \\
\text { - } & \text { GDF Suez } \\
\text { - } & \text { France }\end{array}$ \\
\hline
\end{tabular}

a 2016. Share of all bonds issued with second opinions. Others are 5.9\%. Authors' calculations based on number of issues using CBI data. Climate Bonds Initiative. Labelled green bonds data. https://www.climatebonds.net/ cbi/pub/data/bonds (accessed 7 July 2017).

Source: Adapted from HSBC (2016) and UniCredit (2016).

\section{Certification and Verification}

Certification is the pre-issue assessment by an approved firm with environmental expertise that the green bond framework complies with a specific standard. Verification confirms ongoing compliance by the issuer after the bond has been issued. At present, there is only one green bond standard, the CBI Standard (section C earlier in this chapter). Some see certification with the CBI Standard as a more rigorous process than second opinions because of the use of detailed sector-specific criteria for the environmental impacts of projects and assets. As of 31 March 2017, 32 firms have been approved as verifiers of the CBI Standard, including three from the PRC (Syntao Green Finance, Zhongcai Financing 
Consultants, and China Lianhe Equator). ${ }^{63}$ In addition, the local offices of the global accounting firms offer verification services. Just over 40 bonds had received CBI Standard certification through the end of March 2017. Among ASEAN+3 issues, only AP Renewables (Philippines) had been certified through the end of June 2017.

\section{Ratings}

Both Moody's ${ }^{64}$ and S\&P Global Ratings $s^{65}$ use a transparent scoreboard approach to provide forward-looking opinions about the effectiveness of the issuer to meet green criteria. In both cases, green bonds are provided a ranked grade, which assesses the greenness of each bond. The green bond ratings are not credit ratings, which are issued on a separate basis. ${ }^{66}$ In the PRC, China Chengxin International Credit Rating Company has also developed a green bond methodology, which follows the GBP approach and assigns one of five ratings (G1 = highest, G5 = lowest) to green bonds.

While only a handful of issuers have so far sought green ratings, both Moody's and S\&P Global Ratings have invested heavily to develop their green bond assessment capabilities in the expectation that in the future all bond issuers will seek both a credit and a green rating.

\section{Assurance}

Assurance is an assessment by an independent firm with auditing expertise that the processes used by the issuer to allocate proceeds and to track the use of funds are in accordance with the GBP or a national or international standard. Assurance is also used on a post-issuance basis to confirm that the proceeds have been invested in accordance with the GBP or a national or international standard. The assurance process is based on the International Auditing and Assurance Standards Board's International Standard on Assurance Engagements Other Than Audits (ISAE 3000), or national equivalents. In the PRC, assurance services are often combined with second opinions. The largest provider of assurance services in the PRC is EY.

\section{Investors in Green Bonds}

Investors in green bonds can be divided between institutional investors and retail investors, asset owners and asset managers, foreign investors and domestic investors, and conventional investors and responsible investors. The major institutional investors are banks, pension plans, insurance companies, central banks, and sovereign wealth funds. Their portfolios are managed by in-house investment teams, independent asset managers,

63 Zhongcai Green Financing Consultants Ltd. has emerged as the commercial arm of the Research Center for Climate and Energy Finance. Previously, this group was known as the Climate and Energy Finance Center at CUFE.

Moody's Investor Services. 2016. Green Bond Assessment Methodology. New York.

S\&P Global Ratings. 2017. Green Evaluation Analytical Approach. New York.

66 That said, ESG factors do have an impact on credit ratings and both Moody's and S\&P Global Ratings have committed to greater ESG integration into their credit analysis. Along with six other rating agencies (including three from the PRC and one from Malaysia), they have signed the United Nations Principles for Responsible Investment (UNPRI) Statement on ESG in Credit Ratings. ASEAN+3 signatories are CXXI, Dagong Global Credit Ratings, Golden Credit Rating International and RAM Ratings. 
or both. As the size of a portfolio increases, asset owners are more likely to use in-house investment teams. Asset management firms are another type of institutional investor, although they manage funds on behalf of asset owners, such as pension plans. Asset managers also invest funds for individuals, most often through mutual funds and exchange traded funds (ETFs). Domestic investors are located within a country and tend to have a large percentage of their total portfolio invested in securities denominated in the local currency. Foreign investors are located outside a country and they tend to prefer securities issued in the major reserve currencies. ${ }^{67}$

The distinction between conventional investors and responsible investors is an important one for green bond markets. Conventional investors are investors whose investment decision-making processes focus on financial factors, such as profitability, cash flow, and debt levels. This information is provided in the financial statements of entities issuing public securities. The decision-making processes for responsible investors include both financial factors and nonfinancial factors, commonly referred to as ESG factors.

Environmental factors focus on an entity's environmental footprint (such as carbon emissions); social factors deal with the treatment of employees, consumers, and communities; and governance factors address organizational structures. ${ }^{68}$ Information on ESG factors is available from some issuing entities and specialized research firms. Both conventional and responsible investors hold green bonds, but they are especially attractive to responsible investors because the proceeds from green bonds are limited to environmentally beneficial projects and assets.

Two reasons are offered to include ESG factors in the investment management process: the values rationale and the value rationale. The values rationale is grounded in moral judgement: individuals are the ultimate owners of most investable assets so they should be invested in ways that make society better off. Not investing in companies that pollute or that produce harmful products creates an incentive for these companies to change their behavior or risk being cut off from investment capital. The term "ethical investing" is linked to the values rationale. The value rationale argues that ESG factors are potential risks to investment portfolios. Integrating ESG analysis into the investment process provides a better assessment of the expected return of an investment and, thus, will generate superior investment returns. ${ }^{69}$ Further, because ESG factors potentially present material risks to a portfolio, those overseeing the portfolio have a fiduciary responsibility to ensure that ESG factors are considered before an investment is made.

In practice, the dividing line between conventional investors and responsible investors is not clear cut. First, conventional investors do not ignore ESG factors. Financial analysts pay

67 A detailed discussion of investor types is found in ADB. 2013. Broadening the Investor Base for Local Currency Bonds in ASEAN+2 Countries. Manila (especially Chapters III, IV, and V).

68 UNPRI. 2015. Fiduciary Duty in the 21st Century. New York.

69 While there is evidence that ESG factors can be used to identify superior investments in model portfolios, the evidence does not yet support the view that funds using ESG analysis deliver better investment returns. G. Friede, T. Busch, and A. Bassen. 2015. ESG and Financial Performance: Aggregated Evidence more than 2000 Empirical Studies. Journal of Sustainable Finance \& Investment. 5 (4). pp. 210-33; and L. Renneboog, T. Horst, and C. Zhang. 2008. The Price of Ethics and Stakeholder Governance: The Performance of Socially Responsible Funds. Journal of Corporate Finance. 14 (3). pp. 302-22. 
close attention to management quality and repeated penalties for violating environmental rules, hostile labor relations, and boycotts of a company's products and services are signals of poor management. The key difference is that conventional investors treat ESG analysis in an informal, ad hoc manner, whereas responsible investors systematically integrate ESG analysis into their investment processes.

Second, responsible investing encompasses a range of activities and strategies. The major ones include (i) negative or exclusionary screening, (ii) positive or best-in-class screening, (iii) norms-based screening, (iv) integration of ESG factors, (v) sustainability themed investing, (vi) impact or community investing, and (vii) corporate engagement and shareholder action..$^{70}$ Many conventional investors engage in at least one of these activities for at least part of the funds that they manage. Third, responsible investors engaged in these activities and strategies do not always do so for their entire portfolio or do not always do so in ways that ESG proponents would consider credible. Thus, the conventionalresponsible investor divide is better seen as a spectrum, with investors who largely ignore ESG factors at one end and investors who fully embrace ESG activities and strategies at the other.

\section{a. Responsible Investing in Asia ${ }^{71}$}

The Global Sustainable Investment Alliance estimates that $\$ 22.9$ trillion of assets were managed using responsible investing strategies in 2016. This represents $26 \%$ of global professionally managed assets. Most responsible investing occurs in Europe ( $\$ 12.0$ trillion) and the US ( $\$ 8.7$ trillion). About $75 \%$ of responsible investing assets are managed for institutional investors. Fixed income securities account for about $64 \%$ of the assets using responsible investment strategies..$^{72}$ Negative screening, ESG integration, and corporate engagement and shareholder action were the most common responsible investment strategies.

Responsible investing is less common in Asia. In Japan, responsible investing assets totaled $\$ 473.6$ billion (2.1\% of global responsible investing mandates), with almost $60 \%$ limited to corporate engagement and shareholder action. In the rest of Asia, $\$ 52.1$ billon (0.2\%) was in responsible investing mandates, with almost half in Sharia-compliant funds. The limited size of responsible investment mandates is reflected in the small number of institutional investors from ASEAN +3 countries who are signatories to the United Nations Principles for Responsible Investment (UNPRI). ${ }^{73,74}$

\footnotetext{
Global Sustainable Investment Alliance. 2016. Global Sustainable Investment Review, 2016. Washington, DC. p. 6. Unless otherwise noted, all figures in this section are from Global Sustainable Investment Alliance. 2016. Global Sustainable Investment Review, 2016. Washington, DC.

72 This figure is for Europe and Canada only. Other regions did not collect this information.

73 The UNPRI are voluntary principles promoting sustainable development. Signatories are asset owners, investment managers, and service providers who commit to six principles: (i) incorporate ESG issues into investment analysis and the decision-making process, (ii) be active owners and incorporate ESG issues into ownership policies and practices, (iii) seek appropriate disclosures on ESG issues by entities in which they invest, (iv) promote acceptance and implementation of the Principles within the investment industry, (v) work together to enhance effectiveness in implementing the Principles, and (vi) each member will report on their activities and their progress toward implementing the Principles.

74 As of 31 July 2017 , the UNPRI had 1,769 members. Of this total, 107, or about $6 \%$, were entities from ASEAN+3 countries, of which more than half were from Japan.
} 
These findings were supported by discussions with market participants in the PRC, the Republic of Korea, Malaysia, the Philippines, Singapore, and Thailand. Most market participants indicated that ESG analysis or responsible investing generally did not factor into the investment policies, mandates, and decisions of domestic institutional investors. Most indicated that ESG analysis was limited to negative screening of morally objectionable companies rather than a more broad-based approach. Market participants in Malaysia generally had greater awareness of ESG factors, which likely reflects the large role of Islamic finance and its greater consideration of social factors in financing decisions. Investment professionals at the local subsidiaries of some foreign financial institutions also had greater awareness of ESG factors.

Market participants indicated that interest among retail investors for responsible investing products was low. This accounts for the relatively small number and size of responsible investment products available in ASEAN +3 countries.$^{75}$ Institutional investors also said that they had experienced no pressure from clients or civil society organizations to consider ESG factors in their investment decision-making processes. These factors have been central to the development of demand for green bonds by institutional investors in Europe and North America.

\section{b. Who Holds Green Bonds?}

A precise breakdown of who owns the outstanding stock of green bonds is not known. Placement details from green bond issuers indicate that they are largely held by institutional investors - such as asset managers, pension plans, insurance companies, and banks-in proportions similar to conventional bonds. The main difference with conventional bonds is that green bonds are more likely to be held by investors with responsible investment mandates. Based on a small sample of issuer disclosures on investor type, about $45 \%-65 \%$ of green bonds appear to be placed with investors with responsible investment mandates. ${ }^{76}$ This is a much higher percentage than their share of globally managed assets, which is about $25 \%$. Most of the green bonds held by responsible investors are in broad ESG mandates - green bond funds total only about $\$ 1$ billion (section c). A survey of green bond investors suggests that a significant share of green bonds tend to be held on a buy-andhold basis, which reduces liquidity in secondary markets. ${ }^{77}$

Institutional investors, both on an individual and collective basis, have been supportive of the development of green bond markets and, in particular, the development of credible standards. For instance, 27 global investors representing \$11 trillion in assets signed the Paris Green Bond Statement calling for clear standards, greater transparency, and government support to promote the development of green bond markets. Similarly, European LongTerm Investors, the Institutional Investor Group on Climate Change, and the Investment

75 The number of responsible investment funds available to retail investors in ASEAN+3 countries is not known. The Global Sustainable Investment Review, 2016 states that there are 658 responsible investment funds in Asia ex-Japan, although it does not provide a breakdown by country. Market participants in the ASEAN+3 countries visited in the fieldwork for this report said that the number of responsible investment funds is small.

76 This is consistent with a survey of green bond investors that found almost half made green bond investments without having a specific sustainability, green, or ESG policy in place. Euromoney. 2015. Green Bond Survey: What Investors Want. September.

77 Novethic. 2016. Green Bonds: An Investors' Perspective. September. p. 1. 
Network on Climate Risk have released statements encouraging greater investment in low-carbon projects. Several asset owners have also committed to increase their holdings of green bonds or to divest from large carbon emitters.

Issuers in ASEAN+3 countries report different placement experiences between foreign and local currency green bonds. The placement of foreign currency green bonds closely matches the global experience, where about half go to responsible investors. In contrast, local currency green bonds have been placed almost entirely with domestic conventional investors.

\section{c. Green Bond Funds}

Green bond funds are a recent addition to the investment landscape (Table 17 and Appendix II). At present, they have total assets of about $\$ 1$ billion, or less than $1.0 \%$ of the outstanding stock of green bonds. Most have been launched in Europe since 2015 and use euros as the base currency. This reflects the much greater awareness of and interest in green bonds among individual and institutional investors in Europe. Based on a review of these funds, several observations can be made:

(i) Green bond funds are small and interest in them remains limited. While in quarterly asset growth in some cases has been impressive, this is based on a small initial size and the total flow of funds remains modest.

(ii) Some of the funds have high minimum investment sizes (e.g., \$1 million), making them relevant only to high net worth individuals and institutional investors.

(iii) The funds are managed against several benchmarks. The most common is the Bloomberg Barclays MSCI Green Bond Index. Several funds do not report their performance against a benchmark.

(iv) Most funds seek to hold predominantly green bonds, though many set $70 \%$ or $80 \%$ as the minimum. In practice, fund managers report green bond holdings from $90 \%$ to $100 \%$. Green eligibility is defined as inclusion in the green bond index tracked by the fund, compliance with the GBP, and/or compliance with the CBI Standard. Fund offering documents sometimes allow the investment manager to determine if a bond meets sustainable criteria and thus eligibility for the fund.

(v) The number of issuers held in the funds is small compared to conventional bond funds.

(vi) Fund holdings of green bonds by issuers from ASEAN +3 countries are modest. They tend to be issues of large size dominated in US dollars or euros. Holdings include Hyundai, Mitsubishi UFJ, Bank of China, MTR, and the Export-Import Bank of Korea.

(vii) Green bonds issued by ADB are held by several green bond funds.

The Amundi-IFC Green Cornerstone Fund, with a target size of $\$ 2$ billion, will be more than twice the size of all existing green bond funds combined, significantly changing the green bond fund landscape. The fund "will buy green bonds issued by banks in Africa, Asia, the Middle East, Latin America, Eastern Europe, and Central Asia." 78 The fund is being 


\section{Table 17: Green Bond Funds}

\begin{tabular}{|c|c|c|c|c|}
\hline \multirow[b]{2}{*}{ Name } & \multicolumn{2}{|c|}{ Size } & \multirow[b]{2}{*}{ Inception Date } & \multirow[b]{2}{*}{ Jurisdictior } \\
\hline & Value & \$ Equivalent & & \\
\hline Allianz Green Bond Fund & $€ 64$ million & $\$ 72$ million & November 2015 & Europe \\
\hline Amundi Green Bonds Fund & $€ 26$ million & $\$ 29$ million & December 2015 & France \\
\hline Amundi-IFC Green Cornerstone Fund & \multicolumn{4}{|c|}{ Announced in April 2017; no investments yet; target size of $\$ 2.0$ billion } \\
\hline AXA World Funds Planet Bonds & $€ 85$ million & $\$ 95$ million & September 2015 & Europe \\
\hline Blackrock Green Bond Index Fund & $€ 23$ million & $\$ 26$ million & January 2017 & Europe \\
\hline Calvert Green Bond Fund & $\$ 74$ million & $\$ 74$ million & October 2013 & US \\
\hline HGA Obligations Vertes & $€ 174$ million & $\$ 195$ million & October 2015 & France \\
\hline Lyxor Green Bond UCITS ETF & $€ 10$ million & $\$ 12$ million & April 2017 & Europe \\
\hline Mirova Green Bond - Global Fund & $€ 149$ million & $\$ 167$ million & June 2015 & Europe \\
\hline Mirova Global Green Bond Fund & $\$ 25$ million & $\$ 25$ million & February 2017 & US \\
\hline NN Euro Green Bond Fund & $€ 94$ million & $\$ 105$ million & March 2016 & Europe \\
\hline Raiffeisen Green Bond Fund & $€ 50$ million & $\$ 56$ million & September 2015 & Austria \\
\hline SMBC Nikki World Bank Green Bond Fund & $¥ 6.5$ billion & $\$ 59$ million & June 2010 & Japan \\
\hline Nikki AM World Bank Green Bond Fund & $\$ 35$ million & $\$ 35$ million & 2010 & Europe \\
\hline Nikki AM Shenton W.B. Green Bond Fund & S\$14 million & $\$ 10$ million & 2010 & Singapore \\
\hline SEB Green Bond Fund & $€ 99$ million & $\$ 111$ million & April 2015 & Europe \\
\hline State Street Global Green Bond Index Fund & n.a. & n.a. & May 2017 & Europe \\
\hline VanEck Vectors Green Bond ETF & $\$ 5$ million & $\$ 5$ million & March 2017 & US \\
\hline
\end{tabular}

n.a. $=$ not applicable, $U S=$ United States.

Notes: Bond sizes are as of various dates in 2017 (see Appendix for details). Conversion rates as of 31 May 2017 are as follows: $€ 1.0=\$ 1.1211, ¥ 1.0=\$ 0.0090, S \$ 1.0=\$ 0.7234$.

Source: Websites of Green Bond Funds.

promoted by the IFC to encourage banks in emerging markets to issue green bonds. Banks have been the largest issuers of green bonds in Europe and the PRC, and they represent a likely source of issuance in other economies.

The IFC will contribute $\$ 325$ million to the fund, with the remainder to be raised by Amundi from institutional investors. Of the IFC participation, $\$ 125$ million is a first loss tranche. There will also be a mezzanine tranche purchased by Amundi and other investors interested in higher yield, taking on the second loss risk. This provides senior investors with excellent loss protection, plus the yield from emerging and frontier market financial institutions, making the fund very attractive to conventional investors chasing yield. Approximately $30 \%$ of investors in the fund have specific green or SRI mandates, with the balance attracted by the yield and tranching. The fund aims to be fully invested by 2024 .

Perhaps the most important aspect of the Amundi-IFC Green Cornerstone Fund is the plan by the IFC to support green bond issuance by emerging and frontier market banks. The IFC has raised donor funding to support technical assistance to $20-25$ banks in bringing green 
bonds to market, thus helping to address the major constraint on the fund, the current lack of investable assets.

\section{d. What Do Investors Want?}

Two studies have surveyed institutional investors regarding their views on green bonds. ${ }^{79}$ The respondents to both surveys were composed largely of institutional investors from Europe and North America. The key findings of the study by Euromoney are as follows:

(i) Almost $70 \%$ of green bond investments supported renewable energy projects.

(ii) Insurance companies and foundations showed the greatest interest in green bonds; high net worth individuals showed the least.

(iii) Second opinions issued with green bonds are heavily relied upon and are broadly trusted by investors.

(iv) Investors want to see more corporate issuance of green bonds.

(v) Existing investors in green bonds are comfortable with the lack of a definitive definition of green bonds, which remains a concern for investors not yet in the market.

(vi) Almost $60 \%$ of respondents would like to see mandatory rules to govern green bond issuance.

The key findings of the Novethic study are as follows:

(i) Green bond markets suffer from a lack of corporate issues, small issue size, and illiquidity due to the large number of buy and hold investors.

(ii) Green bonds are seen as an effective way to meet ESG mandates.

(iii) Most investors see green bonds as having the same financial characteristics as conventional bonds; some hope that they will eventually have better financial characteristics by avoiding climate risks.

(iv) There is high support for the GBP and the CBI Standard.

(v) Investors want to see more reliable environmental impact assessments.

Market participants from ASEAN +3 with a knowledge of green bond markets offered comments that aligned closely with these findings. The main difference is a stronger preference for a standard definition of eligible green projects and a comprehensive regulatory regime governing green bond issuance.

\section{J. Green Bond Indices}

An index is a basket of securities that is intended to measure the performance of a segment of capital markets. Indices exist for stocks, bonds, currencies, and commodities, plus many other asset classes. Multiple indices exist for each asset class. Indices are used by investment managers to construct investment products, manage portfolio risk, and

79 Euromoney. 2015. Green Bonds Survey: What Investors Want. September. This includes a survey of 38 institutional investors with combined green bond holdings of $\$ 3.5$ billion; Novethic. 2016. Green Bonds: An Investors' Perspective. September. This includes a survey of 17 institutional investors with combined green bond holdings of $€ 7.7$ billion. 
assess investment performance. ${ }^{80}$ Indices require inclusion criteria (e.g., what securities are included in the index?) and construction rules (e.g., how are the securities aggregated, how are new securities added to the index? under what conditions are existing securities removed from an index?). Globally, thousands of indices exist, and while any entity can construct an index, the industry is highly concentrated. Most bond indices were developed by investment banks to support their market-making and underwriting businesses, but recently most have sold their index units to specialized financial data providers, such as Bloomberg, MSCl, Standard \& Poor's, IHS Markit, and FTSE Russell.

To construct a green bond index, an index provider must first establish green eligibility criteria for green bonds. This is often done in consultation with a firm with environmental finance expertise. The green eligibility criteria could include only green labeled bonds, expert-approved green labeled bonds (i.e., green-labeled bonds that are attested to being green by recognized experts), or labeled green bonds (all or expert-approved) plus unlabeled green bonds identified by experts. Next, index providers must establish inclusion criteria based on the economic characteristics of the bond. Currency, minimum credit rating, amount outstanding, coupon type, and term to maturity are the most important inclusion criteria for bond indices. Green eligibility criteria and inclusion criteria are normally developed in consultation with potential users of the index. Lastly, the index provider must set out construction rules. These deal with how constituent components should be weighted and rebalanced, and how bonds are added and removed from the index.

Several green bond indices have been created since 2014. The most widely cited and used global green bond indices are listed in Table 18. Return information on each is available in the multiple currencies on a hedged and unhedged basis. Some indices also provide regional versions of their index. For instance, the Bloomberg Barclays MSCI Green Bond Index includes a Euro Green Bond Index and a US Green Bond Index. Because of

\section{Table 18: Global Green Bond Indices}

\begin{tabular}{|c|c|c|c|c|c|}
\hline & $\begin{array}{l}\text { Bloomberg } \\
\text { Barclays MSCI } \\
\text { Green Bond } \\
\text { Index }\end{array}$ & $\begin{array}{l}\text { S\&P Green } \\
\text { Bond Index }\end{array}$ & $\begin{array}{l}\text { S\&P Green } \\
\text { Bond Select } \\
\text { Index }\end{array}$ & $\begin{array}{l}\text { BofA Merrill } \\
\text { Lynch Green } \\
\text { Bond Index }\end{array}$ & $\begin{array}{c}\text { Solactive Green } \\
\text { Bond Index }\end{array}$ \\
\hline Launch date & November 2014 & July 2014 & February 2017 & October 2014 & March 2014 \\
\hline Green criteria & MSCI defined & CBI defined & CBI defined & BAML defined & CBI defined \\
\hline Number of constituents & 157 & 2,101 & 189 & 167 & 205 \\
\hline Duration & 6.89 & 6.00 & 6.22 & 5.60 & n.a. \\
\hline Yield & 1.38 & 1.97 & 1.69 & 1.44 & n.a. \\
\hline Market value & n.a. & $\$ 171$ billion & $\$ 118$ billion & $\$ 109$ billion & n.a. \\
\hline Funds tracking index & 5 & 0 & 1 & 2 & 1 \\
\hline
\end{tabular}

n.a. $=$ not applicable.

Data as of 30 June 2017.

Sources: International Capital Markets Association. 2017. Summary of Green Fixed Income Indices Providers; company websites; Bloomberg.

80 When assessing investment performance, indices are commonly referred to as benchmarks. 
differences in green eligibility criteria and inclusion criteria, the constituent components of each index differ, although there is a high degree of overlap among them.

With respect to the green eligibility criteria, the Solactive Green Bond Index and the S\&P Green Bond Indices require that green bonds be flagged as green by the $\mathrm{CBI}$. This does not mean, however, that all green bonds identified by the $\mathrm{CBI}$ are included in the index. Bonds classified as green by the $\mathrm{CBI}$ may be excluded due to inclusion criteria, such as minimum issue size or currency. The green eligibility criteria for the Bloomberg Barclays MSCI Green Bond Index require that a bond's use of proceeds fall within one of six $\mathrm{MSCl}$-defined categories and that the bond meet the four principles set out by the GBP, as determined by the MSCI ESG Research team. ${ }^{81}$ Green eligibility criteria for the BofA Merrill Lynch Green Bond Index requires bonds to "have a clearly designated use of proceeds that is solely applied to projects or activities that promote climate change mitigation or adaptation or other environmentally sustainable purposes." 82 While not specified in the index documentation, it would appear that BofA Merrill Lynch's research team makes this determination.

Key inclusion criteria are listed in Table 19. All of the indices include multiple currencies (including those used by some ASEAN +3 countries), although renminbi issues are excluded from the Bloomberg Barclays MSCl Green Bond Index and the S\&P Green Bond Selected Index. Securities issued in the PRC are commonly excluded from indices because of the difficultly international investors have in purchasing them due to capital controls in the PRC. There has been a trend among index providers to add securities issued in the PRC to indices as capital controls have been eased.

Green bonds issued by entities from ASEAN +3 countries account for a small portion of the global green bond indices. This is because of the small number of issues (apart from the PRC) and because CNY-denominated issues are not found in the index. The absence of renminbi issues may be because of direct exclusionary rules or the failure to satisfy inclusion criteria, such as sufficient liquidity. For instance, the Solactive Green Bond Index

\section{Table 19: Inclusion Criteria for Green Bond Indices}

\begin{tabular}{|c|c|c|c|c|c|}
\hline & $\begin{array}{l}\text { Bloomberg } \\
\text { Barclays } \mathrm{MSCl} \\
\text { Green Bond } \\
\text { Index }\end{array}$ & $\begin{array}{l}\text { S\&P Green Bond } \\
\text { Index }\end{array}$ & $\begin{array}{l}\text { S\&P Green Bond } \\
\text { Select Index }\end{array}$ & $\begin{array}{l}\text { BofA Merrill } \\
\text { Lynch Green } \\
\text { Bond Index }\end{array}$ & $\begin{array}{c}\text { Solactive Green } \\
\text { Bond Index }\end{array}$ \\
\hline Currency & $\begin{array}{l}\text { Multiple } \\
\text { currencies }\end{array}$ & $\begin{array}{l}\text { Multiple } \\
\text { currencies }\end{array}$ & $\begin{array}{l}\text { Multiple } \\
\text { currencies }\end{array}$ & $\begin{array}{l}\text { Multiple } \\
\text { currencies }\end{array}$ & $\begin{array}{l}\text { Multiple } \\
\text { currencies }\end{array}$ \\
\hline Renminbi eligible? & No & Yes & No & Yes & Yes \\
\hline High yield eligible? & No & Yes & Yes & No & Yes \\
\hline Minimum maturity & None & 1 month & 1 month & 18 months & 6 months \\
\hline Minimum issue size & $\begin{array}{l}\text { Varies by } \\
\text { currency }\end{array}$ & $\begin{array}{l}\text { Varies by } \\
\text { currency }\end{array}$ & $\begin{array}{l}\text { Varies by } \\
\text { currency }\end{array}$ & $\begin{array}{l}\text { Varies by } \\
\text { currency }\end{array}$ & $\$ 100$ million \\
\hline
\end{tabular}

Data is at June 30, 2017.

The six categories are alternative energy, energy efficiency, pollution prevention, sustainable water, green building, and climate adaptation.

82 Bank of America Merrill Lynch. 2014. Introducing the Green Bond Index. 30 October. p. 10. 
includes only four issuers from the PRC, all of which are US dollar or euro issues. In total, ASEAN +3 green bonds account for $7.58 \%$ of the Solactive index, ${ }^{83}$ made up of issuers from the PRC (5.13\%), Hong Kong, China (0.73\%), Japan (1.03\%), and the Republic of Korea (0.69\%). ADB green bonds account for $1.22 \%$ of the index.

Two families of indices track PRC green bonds. One is the ChinaBond Green Bond Index Series, which consists of four bond indices. They are prepared by the China Government Securities Depository Trust and Clearing Company (CSDC) in partnership with the CBI and CECEP Consulting for three of the indices and the Industrial Bank for the fourth one (Table 20).

\section{Table 20: ChinaBond Green Bond Index Series}

\begin{tabular}{|c|c|c|c|c|}
\hline & $\begin{array}{l}\text { ChinaBond China } \\
\text { Green Bond Index }\end{array}$ & $\begin{array}{l}\text { ChinaBond China } \\
\text { Green Bond } \\
\text { Selected Index }\end{array}$ & $\begin{array}{l}\text { ChinaBond China } \\
\text { Climate-Aligned } \\
\text { Green Bond Index }\end{array}$ & $\begin{array}{c}\text { ChinaBond CIB Green } \\
\text { Bond Index }\end{array}$ \\
\hline Launch date & April 2016 & April 2016 & September 2016 & January 2017 \\
\hline Green criteria & \multicolumn{3}{|c|}{ CBI and CECEP defined } & CSDC and Industrial Bank \\
\hline No. of constituents & 1,020 & 626 & 308 & 78 \\
\hline Duration & 4.21 & 4.53 & 5.36 & 2.48 \\
\hline Yield & 4.26 & 4.18 & 4.15 & 4.44 \\
\hline Market value & CNY2.5 trillion & CNY2.1 trillion & CNY1.31 trillion & CNY154.2 billion \\
\hline
\end{tabular}

$\mathrm{CBI}=$ Climate Bonds Initiative, $\mathrm{CECEP}=$ China Energy Conservation and Environmental Protection, $\mathrm{CNY}=\mathrm{yuan}, \mathrm{CSDC}=$ China Government Securities Depository Trust and Clearing Company.

Notes:

1. Data as of 26 January 2017 (unless otherwise noted).

2. Number of constituents as of 31 December 2016.

Sources: CSDC; ChinaBond Index. 2017. Monthly Review. February; CBI. 2017. China Green Bond Market 2016. January.

The broadest index is the ChinaBond China Green Bond Index, which includes labeled green bonds and unlabeled green bonds where the issuer receives $50 \%$ or more of their revenues from activities from green activities. The ChinaBond China Green Bond Selected Index also includes labeled and unlabeled green bonds (with the same $50 \%$ threshold on revenues from green activities), but the revenues from issuers of unlabeled green bonds must be in line with the PBOC China Green Bond Endorsed Project Catalogue, the NDRC Green Bond Issuance Guidelines, the GBP, and the CBI Standard. The ChinaBond China Climate-Aligned Bond Index has even tighter green eligibility criteria: $95 \%$ of the issuers' revenues must come from activities from green activities for unlabeled green bonds. The China CIB Green Bond Index includes only labeled green bonds (i.e., those approved as green by the PBOC, NDRC, or CSRC).

The second family of green bond indices is the Central University of Finance and Economies (CUFE)-CNI Green Bond Index Series (Table 21). They are a partnership between the

83 As of July 2017, these were the Agricultural Bank of China (0.62\%), Bank of China (2.42\%), Goldwind New Energy (0.20\%), Shanghai Pudong Development Bank (1.89\%), Link REIT (0.33\%), MTR (0.40\%), Development Bank of Japan (0.34\%), Mitsubishi UFJ (0.34\%) Sumitomo Mitsui (0.35\%), Export-Import Bank of Korea (0.34\%), and Hyundai Capital (0.35\%). 
International Institute of Green Finance at CUFE and the Shenzhen Stock Exchange. The broadest index is the CUFE-CNI High Grade Bond Index, which includes both labeled and unlabeled green bonds. Unlabeled green bonds are identified by the International Institute for Green Finance based on the China Green Bond Endorsed Project Catalogue.

Table 21: CUFE-CNI Green Bond Index Series

\begin{tabular}{l|c|c|c} 
& \multicolumn{1}{|c|}{$\begin{array}{c}\text { CUFE-CNI High Grade } \\
\text { Green Bond Index } \\
\text { Launch date }\end{array}$} & $\begin{array}{c}\text { CUFE-CNI High Grade } \\
\text { Unlabeled Green Bond } \\
\text { Index }\end{array}$ & $\begin{array}{c}\text { CUFE-CNI High Grade } \\
\text { Labeled Green Bond Index }\end{array}$ \\
\hline Green criteria & March 2017 & March 2017 \\
\hline Number of constituents & 259 & 223 & 36 \\
\hline Duration & n.a. & n.a. & n.a. \\
\hline Yield & n.a. & n.a. & n.a. \\
\hline Market Value & CNY1.5 trillion & CNY1.3 trillion & CNY0.2 trillion \\
\hline
\end{tabular}

CUFE = Central University of Finance and Economics, IIGF = International Institute of Green Finance, n.a. = not applicable.

Data as of 11 May 2017 (unless otherwise noted).

Source: IIGF CUFE. 2017. CUFE-CNI Green Bond Index Series Report. May.

Both families include indices with unlabeled green bonds. These outnumber labeled green bonds by a wide margin. Most of these are industrial companies and, particularly transportation companies. The largest issuer of unlabeled green bonds is the China Railway Group. Railway bonds tend to dominate the unlabeled green bond market because of their large issue size and investment grade status, the bonds tend to be for a single project, and railway entities provide good disclosure. This means that railway bonds are easy to analyze as to whether or not they meet green eligibility criteria and their large size and investment quality means that they tend to meet inclusion criteria. ${ }^{84}$

Index inclusion and construction rules can influence corporate behavior. ${ }^{85}$ In fact, the growing constitutive power of index providers to determine what is and is not an eligible security is the subject of growing public scrutiny. ${ }^{86}$ Index providers could play this role for green bond markets, although to date they have relied on existing industry norms to define eligible green bonds rather than developing their own.

\section{K. Securities Exchange Listings}

Dedicated green bond listing boards have been established by several securities exchanges. According to the Sustainable Stock Exchange Initiative, 11 exchanges list green

CBI. 2016. World's First Climate-Aligned Bond Index. September. p. 1.

85 For instance: A. Chattopadhyay, M. Shaffer, and C. C. Y. Wang. Governance Through Shame and Aspiration: Index Creation and Corporate Behavior in Japan. Unpublished.

86 For instance: The Economist. 2017. Financial-Market-Index-Makers are Growing in Power. 24 August. 
bonds, though not all of them are done by way of a dedicated listing board. ${ }^{87}$ The largest exchanges in terms of the number and value of green bond listings are the Luxembourg Stock Exchange, London Stock Exchange, Nasdaq Stockholm, and Oslo BØrs. They list bonds from both domestic and foreign issuers in multiple currencies, and the exchanges have actively sought listings from existing green bond issuers. At the end of 2016, almost three-quarters of all labeled green bond were listed on exchanges. ${ }^{88}$ Nevertheless, like conventional bonds, most secondary trading of green bonds is conducted over-the-counter and not on securities exchanges.

The cost of listing a bond varies by exchange and issue size. Issuers must balance these costs against the benefits of a listing, which includes greater visibility and potentially better liquidity. A listing may also expand the investor base for a bond since the investment policies of some institutional investors restrict holdings to listed securities. However, most bonds trade over-the-counter and many green bonds are bought by investors who intend to hold them until maturity, which limits the need of issuers to incur the additional cost of an exchange listing.

The Shanghai Stock Exchange (SSE) and the Shenzhen Stock Exchange list green bonds, though both are doing so on a pilot basis. ${ }^{89}$ In March 2016, the SSE issued the Circular on Launching Pilot Program for Green Corporate Bonds. Listing rules are consistent with the GBP and the Green Bond Endorsed Project Catalogue of the Green Finance Committee. The SSE established a "Green Channel" to facilitate green bond listings and green bonds are designated with a ticker starting with "G." Green bonds issued in the interbank market are not listed on the exchange. At the end of 2016, 24 green bonds were listed on the SSE, with a value of CNY50.6 billion. The pilot program is expected to become permanent once the green bond market has matured.

Green bonds are also listed on the Singapore Exchange (SGX), ${ }^{90}$ but it does not have a separate listings board for them..$^{91}$ Under the Green Bond Grant Scheme, where the Monetary Authority of Singapore (MAS) provides a grant up to $\$ \$ 100,000$ to offset the cost of external reviews, green bonds must be listed on the SGX to qualify.

Issuers from ASEAN +3 countries have listed a small number green bonds on exchanges outside the region. As of 31 March 2017, the Bank of China and ADB had green bonds listed on the Luxembourg Stock Exchange, while the Bank of China, the Agricultural Bank of China, and the Development Bank of Japan had green bonds listed on the London Stock Exchange.

Securities exchanges require green bonds to meet their general listing requirements for fixed income securities before they can be listed, as well as additional eligibility requirements related to their environmental purpose. Listing requirements may be set out

\footnotetext{
Sustainable Stock Exchanges Initiative. 2017. Report on Progress, 2016. http://www.sseinitiative.org/.

CBI. 2017. The Role of Exchanges in Accelerating the Growth of the Green Bonds Market. April. p. 3.

89 See L. Wei and H. Shuangli. 2017. Stock Exchanges in Support of Sustainable Development: The Role, Actions, and Best Practices. Green Finance in China. Beijing: International Institute of Green Finance CUFE. pp. 10-13.

90 For instance, green bonds issued by the Export-Import Bank of Korea, NTPC, and DBS are listed on the SGX.

${ }_{91}$ Sustainable Stock Exchanges Initiative. Singapore Exchange Fact Sheet. http://www.sseinitiative.org/ (accessed 11 August 2017).
} 
by an exchange, the national securities regulator, or both. Green bond listing requirements on European exchanges are closely aligned with the GBP (Table 22). One area where they go further is the mandatory use of external reviews.

\section{Table 22: Overview of Key Stock Exchanges with Green Bond Listings}

\begin{tabular}{|c|c|c|c|c|}
\hline & $\begin{array}{c}\text { Luxembourg Stock } \\
\text { Exchange }\end{array}$ & $\begin{array}{l}\text { London Stock } \\
\text { Exchange }\end{array}$ & $\begin{array}{l}\text { NASDAQ } \\
\text { Stockholm }\end{array}$ & Oslo BØrs \\
\hline \multicolumn{5}{|c|}{ General } \\
\hline Inception date & September 2016 & July 2015 & June 2015 & January 2015 \\
\hline Number of issues & 110 & 42 & 44 & 11 \\
\hline Number of currencies & 19 & 7 & 1 & 3 \\
\hline Value & $€ 47.0$ billion & $\$ 11.2$ billion & SKr21.6 billion & NKr11.8 billion \\
\hline Separate list for green bonds & Yes & Yes & Yes & Yes \\
\hline ASEAN+3 listings & Yes & Yes & No & No \\
\hline \multicolumn{5}{|c|}{ Green Criteria } \\
\hline Use of proceeds & Yes & Yes & Yes & Yes \\
\hline Min. \% for green investments & $100 \%$ & & & \\
\hline Evaluation & & Yes & & \\
\hline Management of proceeds & Yes & Yes & & \\
\hline Post-issuance reporting & Yes & Yes & Yes & Yes \\
\hline Pre-issuance external reviews & Yes & Yes & Yes & Yes \\
\hline
\end{tabular}

Note: Market data are as of the end of 2016.

Source: SEB. 2017. Green Bonds-Key Facts and Findings. January. p. 9; stock exchange websites.

Securities exchange listing requirements have long been a source of corporate standards. Rules on director composition and duties, share structures, shareholder voting, and disclosures on such activities as executive compensation and the use of proceeds from conflict minerals, are examples of listing requirements that influence corporate behavior. Many exchanges are now requiring ESG reporting as well. ${ }^{92}$ Listing requirements can serve as a seal of approval for listed and unlisted companies alike. However, securities exchange listings for green bonds are unlikely to have much influence on green bond standards for two reasons. First, green bond listing requirements have followed rather than led other standard setting efforts. Second, and perhaps most important, institutional investors tend to have little interest in bond listing requirements since most bonds trade off exchanges. 


\title{
III. Policy Options for Promoting Local Currency Green Bonds
}

\begin{abstract}
This chapter identifies and evaluates policy actions to promote the development of local currency green bond markets in ASEAN +3 countries. Most of the policy options considered have been discussed elsewhere, though their proponents have not always evaluated their likely effectiveness or potential for adverse impacts on other policies, nor have they tailored their proposals to the specific needs of local currency bonds in the ASEAN +3 region. ${ }^{93}$ Consequently, this chapter not only considers policy priorities, it also discusses policy options that do not warrant further consideration at this time. ASEAN+3 governments will have the greatest impact on the development of local currency green bond markets if they focus on a small number of high-impact policies that are properly sequenced.
\end{abstract}

The chapter evaluates the policy options available to ASEAN+3 governments, which have been grouped into six general types of policies:

(i) preconditions for local currency green bond markets,

(ii) establishing a policy framework for green bond markets,

(iii) expanding the supply of green bonds,

(iv) facilitating demand for green bonds,

(v) general market development initiatives, and

(vi) regional initiatives to support green bond markets.

The first five policy areas address national policies available to individual governments to promote the development of local currency green bond markets in their home countries. The sixth policy area identifies policies that could be pursued on a regional basis. Many of these policies, of course, support and are extensions of national policies.

The suitability of each policy for a particular country will vary. Local currency bond markets are at different stages of development across the region; the legal and policy frameworks supporting them vary, as does the extent of current green bond development. Consequently, while many policies are identified that will assist ASEAN +3 governments to promote their local currency green bond markets, the most appropriate basket of policies for each country must be tailored to local circumstances.

For instance, European Commission. 2016. Study on the Potential for Green Bond Finance for Resource-Efficient Investments. Brussels; G20 Green Finance Study Group. 2016. G20 Green Finance Synthesis Report. Toronto; CBI. 2015. Scaling Up Green Bond Markets for Sustainable Development. London; CBI. 2017. Study of China's Local Government Policy Instruments for Green Bonds. London; OECD. 2017. Mobilising Bond Markets for a Low-Carbon Transition; and European Union High Level Group on Sustainable Finance. 2017. Financing a Sustainable European Economy, Interim Report. Brussels. 


\section{A. Preconditions for Local Currency Green Bond Markets}

reen bond markets will only emerge in jurisdictions that have met the basic

$\checkmark$ preconditions for local currency bond market development more generally. Specialized debt instruments such as green bonds or project bonds for infrastructure financing will only be issued in jurisdictions where the use of general obligation bonds is well established. Policies to promote the overall development of local currency bond markets should therefore remain the top priority for ASEAN +3 governments. The discussion of these policies draws on two earlier reports on local currency bond markets prepared for ADB. ${ }^{94}$

Another precondition for the emergence of local currency green bond markets is an adequate supply of green financing opportunities. The issue here is not so much the availability of potential green projects and assets-market participants, government officials, and official studies all point to the large investments needed to put national economies onto a sustainable development path-but the challenge of turning proposed green projects into financially viable investments.

\section{Local Currency Bond Markets}

The policy rationale for promoting local currency bond markets extends well beyond the desirability of green financing. Local currency bond markets can provide an alternative to international bank financing, enhancing financial stability by providing a "spare tire" to serve as a buffer against potentially volatile capital flows. Local currency bond markets offer a means to intermediate between the pools of local capital arising from typically high domestic savings rates across ASEAN +3 countries on one hand and large investment needs on the other. With the prerequisites for bond market development in place, the foundation then exists for green bond financing to emerge.

Governments need to promote local currency bond markets through domestic policies and through regional and international fora. The basic requirements for local currency bond market development are well known, and within ASEAN+3 there are examples of varying approaches to implementing the required reforms. Common elements that have contributed to successful development of local currency bond markets across ASEAN+3 countries and elsewhere include:

(i) close cooperation between government and market participants, who should share the common objective of developing the local currency bond market;

(ii) a modern legal framework including company and insolvency laws;

(iii) a disclosure-based regime for securities regulation and capital markets oversight, which is aligned with the International Organization of Securities Commissions Principles and Objectives of Securities Regulation;

94 A.M. Andrews, R. Hannah, and B. Sutton. 2013. Broadening the Investor Base for Local Currency Bonds in ASEAN+2 Countries. Manila: ADB; and A. M. Andrews and P. Braginetz. 2015. Local Currency Bonds and Infrastructure Finance in ASEAN+3. Manila: ADB. 
(iv) a government debt program that includes scheduled benchmark-sized issues over a range of tenors to provide a government yield curve, a key requirement for the development of the corporate bond market;

(v) infrastructure to support issuance and trading of debt securities, including securities depositories with immobilized or dematerialized certificates, custodians, and a large-value transfer system capable of providing irrevocable payment, ensuring there is delivery versus payment in the settlement of securities;

(vi) a mechanism to collect and disseminate information on bond trading and bond pricing to facilitate secondary market trading and marking debt instruments to market prices;

(vii) market-makers and provisions for securities lending to facilitate secondary trading; and

(viii) careful consideration of the impact of tax policy on bond market development in terms of the impact of withholding and transactions taxes (stamp duty) as well as the costs and benefits of incentives or benefits targeted at bond market development.

There is a symbiotic relationship between the development of contractual savings and bond markets, making the legal framework and supervisory regimes for pensions, life insurance, annuities, and collective investment schemes an important element of bond market development. As pools of contractual savings accumulate, the resulting domestic institutional investors create demand for debt instruments, both government and corporate. In interviews undertaken for this and two earlier reports, institutional investors across ASEAN+3 almost universally reported a shortage of debt instruments, indicating they would hold more corporate bonds in their portfolios if available. ${ }^{95}$ Thus, while measures to broaden the investor base and increase demand for local currency bonds may be helpful, there is potentially much greater return from measures to increase supply.

In the early 2000s, Malaysia and Thailand adopted capital market masterplans, which in both countries continued with follow-on plans, reflecting that capital market development is a long-term endeavor. An effective alternative to the masterplan approach is seen in Singapore, where there has been a series of initiatives, led by the MAS, to address specific identified obstacles. This has included actively building the government yield curve through a scheduled issuance of benchmark government securities even though Singapore's strong fiscal position means the government has no actual financing needs.

The sequencing of reforms is important, requiring an initial emphasis on the legal foundation, regulatory and supervisory framework, and the infrastructure to support issuance and trading. In the cases of Malaysia, Singapore, and Thailand, new or substantially revised capital market laws and regulations were important early priorities in bond market development. Similarly, there needs to be an early and ongoing emphasis on building supervisory capacity to ensure that the markets are subject to effective oversight. Only when the legal framework, supervisory capacity, and the supporting infrastructure of securities depositories and clearing, payment, and settlement systems are in place should governments consider targeted policy interventions to promote bond market development. 
At the regional level, development of local currency bond markets and promotion of financial cooperation and integration has been the focus of the ASEAN +3 policy makers participating in the Asian Bond Markets Initiative (ABMI) since its inception in 2002. At the strategic level, ABMI-related policies have addressed macroeconomic issues and financial sector reform. These have been augmented by task forces focusing on promoting the supply of local currency bonds, facilitating demand, strengthening the regulatory framework, and improving the related infrastructure for bond markets. ${ }^{96}$

Establishing the preconditions for green bond issuance is an incremental aspect to the important policy considerations that warrant pursuit of local currency bond market development. Across ASEAN+3, significant resources have been devoted to bond market development, with both regional and country-specific workplans in place. ${ }^{97}$ The countries that have made significant progress in bond market development are among those that have begun to see green bond issuance: the PRC, Japan, the Republic of Korea, Malaysia, the Philippines, Thailand, and Singapore.

\section{Local Currency Infrastructure Finance}

Southeast Asia has estimated infrastructure investment needs of more than $\$ 180$ billion annually through $2030 .{ }^{98}$ This exceeds what can be financed through government budgets, placing a premium on public-private partnerships (PPPs) and other means of attracting private sector infrastructure investment. Local currency financing of infrastructure projects avoids the currency risk that can arise when a project generating revenues in the local currency has foreign-currency-denominated debt service requirements.

Given the significant demand among institutional investors across ASEAN +3 for high quality local currency bonds and the demand for infrastructure financing, there is an opportunity to make greater use of project bonds (Box 2). One of the challenges in many countries across the region is the small size of the domestic financial sector, particularly nonbank institutional investors, relative to the needed investment in infrastructure. As a result, when infrastructure is financed in local currency, the funding tends to come from local banks, which, within most countries in ASEAN+3, are the dominant providers of financing for infrastructure that is not funded through government budgets. ${ }^{99}$ Even if domestic institutional investors cannot provide all of the infrastructure financing required, increased use of local currency project bonds would help to reduce the foreign currency and capital flow risks arising from international investment and mitigate the maturity transformation and concentration risks arising from reliance on banks for infrastructure financing.

96 More details are in A. Noy Siakhachanh. 2017. The Asian Bond Markets Initiative: Policy Maker Achievements and Challenges. Manila: ADB.

97 The current state of bond markets was reported in ADB. 2012. ASEAN+3 Bond Market Guide. Manila. An updated version with details through 2016 for some countries is available at https://asianbondsonline.adb.org/regional/abmf .php; See also the country appendixes in A.M. Andrews and P. Braginetz. 2015. Local Currency Bonds and Infrastructure Finance in ASEAN+3. Manila: ADB.

98 ADB. 2017. Meeting Asia's Infrastructure Needs. Manila.

99 More details are in A. M. Andrews and P. Braginetz. 2015. Local Currency Bonds and Infrastructure Finance in ASEAN+3. Manila: ADB. 
The most important policy measures to increase project bond financing do not relate to the bond markets themselves, but to measures that facilitate completion of the preparation phase of infrastructure projects. That said, as with any specialized bond, there must be well developed local currency bond markets with all the prerequisites discussed above for project bonds to become commonly used for infrastructure financing.

The bulk of private infrastructure investment takes place through PPP structures, making a robust PPP framework a prerequisite for the development of project bond financing. The biggest obstacle to increase infrastructure investment is generally not financing, but rather bringing viable projects to market. ${ }^{100}$ Frequently this is due to shortcomings in project preparation, which can include a shortage of resources and expertise within government, the absence of or shortcomings in the legal framework for PPPs, uncertainly over offtake agreements and concessions, challenging and time-consuming licensing and permitting procedures, and obstacles to land and right-of-way acquisition. Thus, policy makers need to ensure that the obstacles to planning and preparing infrastructure projects are addressed.

The use of local currency project bonds and sukuk is limited in ASEAN +3 countries with the exception of Malaysia, and more recently Japan; however, the needed specialized project finance expertise can be made available across the region. Professional advisors are available in the international market. Over time this can lead to knowledge transfer, as in the case of Malaysia where project finance expertise has become well established. Domestic institutional investors can develop expertise in infrastructure investment by partnering with international investors that have already developed the expertise or can pool their resources to more cost effectively acquire the necessary skills.

The Mega Solar Project Bond Trust was established in Japan in 2014 and to date has provided project bond financing for 17 solar generation installations totaling $¥ 30$ billion ( $\$ 280$ million). The securities are typical project bonds, backed by project assets with debt service and repayment solely dependent on the cash flow of the underlying project; there is no recourse to project sponsors. Use of the bond trust structure addresses the obstacle of relatively small issue sizes. While institutional investors will typically look to a minimum issue size of $\$ 200$ million, use of a standardized asset-backed bond issued by the trust facilitates investment in a portfolio of smaller issues. All of the Mega Solar Project Bond Trust issues to date are clearly climate aligned as each separate legal entity is dedicated to renewable energy generation. The first green-labeled project bond in Japan was issued through the Mega Solar Project Bond Trust in April 2017. This was a $¥ 5.4$ billion issue by Canadian Solar Inc.'s Gunma Aramaki Solar Power Plant, with a second opinion by Japan Research Institute Limited. ${ }^{101}$

The typical project bond structure lends itself well to issuing green bonds. The stand-alone legal entity simplifies the verification of the use of proceeds when the underlying project qualifies under the GBP categories. The well-established Malaysian project bond and sukuk model could easily be adapted from its traditional use in financing thermal power

\footnotetext{
Footnote 99

101 Bloomberg. 2017. Goldman on Track to Hit \$1 Billion Japan Clean Energy Bond Goal. 17 April. https://www.bloomberg .com/news/articles/2017-04-17/goldman-on-track-to-hit-1-billion-japan-clean-energy-bond-goal. Although coded as green in Bloomberg, this bond is not included in the CBI database.
} 


\section{Box 2: Project Financing and Project Bonds}

Project financing has a distinct set of characteristics. It requires specialized expertise on the part of the project sponsors and their advisors to present an attractive investment, and on the part of investors to understand and assess a project's risks.

Typically, the project is established as a stand-alone legal entity, with the cash flow from the project meeting the debt service requirements and providing the return to equity investors. There is usually no or limited recourse to the project sponsors. Project sponsors may be governments, construction firms, or infrastructure operators. They invest in the project company, usually in the form of equity or junior debt, and may provide some guarantees or limited recourse as a means of reducing the risks assumed by other investors, such as banks or bondholders, to make investment in the project more attractive. Investors in the project share in the inherent risks, including construction, operation, political, and revenue risk. Credit enhancements in the form of guarantees from export credit agencies or specialized guarantee facilities such as the Indonesian Infrastructure Guarantee Faculty may also be used to reduce the risk to investors. Guarantees may be either full (credit wraps) or partial.

Once a project has passed the preparation stage and reached financial close-that is, the needed financing for the project has been committed-the construction phase introduces completion risk. This arises from the possibility of delays, higher-than-budgeted costs, or even abandonment of the project. Once the construction phase is completed there are operational risks over the typically long payback period of an infrastructure project. These include but are not limited to failure to meet output projections, resulting in lower-than-planned revenues; supply price risk; and the risk of equipment becoming obsolete or having a shorter economic life than projected. There is also the risk that the offtake agreement counterparty (e.g., electric utility) may not honor the terms of the agreement. Broader risks that can affect projects include country and political risks and the threat of macroeconomic instability. There may be industry-specific risks and social and environment concerns.

Project bonds are a type of debt instrument used to finance all or part of a project. Repayment is dependent on the success of the project. While there is generally no recourse to the project sponsors, investors can draw comfort from financially sound sponsors with a track record in similar projects. Project bonds can be used from the outset (the greenfield stage) as the primary financing source for an entire project, generally issued in tranches to minimize the negative carry from investing bond proceeds until the funds are actually needed for the project. Project bonds may also be used as part of a financing package. Probably the most common use of project bonds is to take out the initial financing when construction is complete or the original syndicated loan financing matures (the brownfield stage).

Source: A. M. Andrews and P. Braginetz. 2015. Local Currency Bonds and Infrastructure Finance in ASEAN+3. Manila: ADB.

generation and toll roads to renewable energy and low-carbon transportation. The key elements include project sponsors with a good track record and the financial resources to support an equity or junior debt financing tranche, a long-term power purchase agreement or operating concession to provide project cash flow, and participation by key institutional investors to ensure the success of the project bond issue. 
As with local currency bond market development more generally, the rationale for promoting the use of green project bonds is incremental to the already compelling arguments for encouraging the use of local currency bonds for infrastructure finance. Policy efforts directed toward local currency bond market development and providing a basis such as PPPs to attract private sector financing for infrastructure have the concurrent benefit of laying the foundation for project bonds, and thus generate no incremental costs with respect to promoting the green bond market. When these policy efforts are complemented by national frameworks conducive to green bond issues, the conditions will exist for the use of green project bonds.

Efforts to address the main bottleneck in attracting private investment in infrastructurebringing investable projects to market-continue to be required. This includes the required legal foundation and ensuring there is the necessary project preparation expertise within the government and the private sector. These measures will complement ongoing efforts to develop local currency bond markets, creating the conditions for the use of project bond financing.

\section{B. Available Green Financing Opportunities}

\section{National Inventory of Potential Green Projects}

The development of a green bond market is dependent on an ongoing supply of viable green projects suitable for financing through bond issuance. What matters to market participants is not only the current supply of projects but expectations of future supply. When both are high, market participants will acquire the requisite expertise to develop green bond markets. Numerous studies have determined that while there is a large need for investment in green projects if Asia is to transition to a sustainable development path, national inventories of finance-ready projects are largely absent. ${ }^{102}$

The starting point would be the preparation by national environmental and/or development agencies of a priority list of green projects. To ensure alignment with national priorities, the list should be developed as part of a country's overall policy framework to meet the UN SDGs or NDCs under the Paris Agreement. The usefulness of the list would be enhanced if each project included a feasibility study and an environmental impact assessment. Putting in place a streamlined regulatory approval process for priority projects would increase effectiveness in channeling investment to green projects.

There are no extant examples; however, the concept is similar to, and could be a subset of, the creation of national inventories of needed infrastructure projects. Creating a priority list of green projects requires significant resources to (i) establish an appropriate policy framework linked to national environmental objectives, (ii) specify criteria to assess the importance of each project, and (iii) put in place a team of experts to identify potential projects and assess their feasibility and environmental impacts. Creating a streamlined regulatory approval process for priority projects requires coordinating among many departments and different

102 A summary of this work is in ADB. 2017. Catalyzing Green Finance: A Concept for Leveraging Blended Finance for Green Development. Manila. 
levels of government. The benefits of a national inventory of green projects extend well beyond its contribution to the development of a green bond market.

ASEAN+3 governments, as part of their planning to meet the UN SDGs or their NDCs under the Paris Agreement, could consider creating a national inventory of projects involving the preparation of feasibility studies and establishment of an expedited approval process to support these national objectives.

\section{Promoting the Financial Viability of Green Projects}

Increasing the financial viability of green projects, particularly those with a cost disadvantage relative to non-green alternatives such as fossil fuel electricity generation, offers the potential to attract incremental investment in green projects. This can facilitate use of green financing instruments including green project bonds.

Incentives can make marginal projects-ones that are potentially profitable but with expected returns falling short of levels required to attract private capital-financially viable. Nontax incentives include preferential off-take or concession agreements as well as producer subsidies or grants, and quotas. Tax incentives can include investment tax credits, increased capital cost allowances (accelerated depreciation for tax purposes), and exemptions from or reductions in the rate of taxation.

Financial viability of privately financed infrastructure projects is typically dependent on an off-take agreement or concession to operate the infrastructure. It is not only the rates, but also the terms and conditions of the agreement, which affect the financial viability of the project. Thus, terms and conditions that reduce the risk to project sponsors and investors can enhance financial viability of green projects.

In one of the most common uses of project financing structures, electricity generation, the power purchase agreement is central to viability. Whether a green or conventional project, sponsors and investors want a long-term agreement, providing certainty of cash flow over the payback period of the investment. The agreement may include minimum purchase commitments or "take-or-pay" provisions to ensure that there will be sufficient demand for the power produced, ensuring minimum cash flow generation and thus reducing the risks to sponsors and investors by transferring the risk to the power purchaser, typically the grid or transmission operator.

Preferential feed-in tariffs have been widely used to promote renewable energy. Specifics vary by jurisdiction, but generally involve purchase of power generated for a fixed period at a rate exceeding that paid for power from conventional sources. Initially, this helped to spur investment despite a cost disadvantage for renewable energy, with the expectation, which has been realized, that over time the costs of renewable energy would converge toward conventional sources. Despite the progress toward cost competitiveness, almost $99 \%$ of worldwide solar power installations are based on a range of market incentives and enablers, almost two-thirds of which relate to feed-in-tariff programs. ${ }^{103}$ These provide the cash

103 International Energy Agency. 2016. Trends in Photovoltaic Application. St. Ursen. 
flow required to make green projects viable. Quotas for a minimum purchase of renewable energy can also contribute to project viability by ensuring a market.

ASEAN + 3 countries including the PRC, the Republic of Korea, Indonesia, Japan, Malaysia, the Philippines, Thailand, and Viet Nam have adopted some form of a feed-in tariff scheme to promote renewable energy. Japan introduced generous feed-in tariffs in 2012 in the wake of the Fukushima earthquake and subsequent shut down of nuclear power plants, requiring utilities to purchase at specified rates for fixed periods electricity produced by approved renewable energy producers. This sparked a wave of investment leading to over $4 \%$ of power being generated by solar plants in 2016, up from virtually nil prior to the 2012 introduction of the preferential tariff program. ${ }^{104}$

In addition to providing preferential feed-in tariffs, the Philippine Renewable Energy Act specifies a minimum percentage of generation from renewable energy resources for power generators and distribution utilities. This provides an incentive for operators of existing fossil fuel plants to diversity into renewables and creates a guaranteed market for energy from renewable resources.

The PRC has used a number of tax incentives to enhance the viability of green projects:

(i) a reduced corporate income tax rate for new technology enterprises including solar, wind, biomass, and geothermal energy;

(ii) a 3-year exemption from corporate income tax, followed by a $50 \%$ reduction for another 3 years, for income derived from qualified environmental protection and water or energy conservation projects;

(iii) a 150\% deduction for qualifying research and development expenses; and

(iv) a 50\% refund of the value-added tax on the sale of wind power.

Malaysia provides a Green Investment Tax Allowance of 100\% of qualifying capital expenditure incurred on approved green technology assets, which can offset up to $70 \%$ of taxable income, as well as a tax exemption for qualifying green service industries.

Tax and nontax incentives have been used around the world to promote green projects. Preferential terms and conditions will spur private sector investment in green projects. This benefit is financed either through higher charges to consumers or through subsidies. Similarly, tax incentives have a counterbalancing fiscal cost as well as administrative and compliance costs, and potentially may provide a benefit for projects that would have been financed without an incentive or subsidy.

The most common way to finance preferential feed-in tariffs is through a specific levy on users of electricity. ${ }^{105}$ In addition to higher rates for consumers, this can be politically unpopular, and it may also include exemptions or reductions for large users of electricity to mitigate the cost disadvantage when competing against manufacturers in jurisdictions not supporting renewable energy through higher electricity prices. A further cost is that utilities

104 Milbank. 2017. Japan's Solar PV Market. https://www.milbank.com/images/content/2/6/26328/Milbank-Client-Alert -Japanese-Solar.pdf.

105 Footnote 103. 
must accept power from solar and wind providers when provided, which means that during periods of high generation from renewables they must cut back supply from conventional sources. The resulting frequent adjustments to output are challenging and costly since the average utilization of conventional power generation, which has high fixed costs, declines.

Long-term agreements providing minimum cash flow guarantees are conducive to the use of green project bonds, and more generally to attracting private investment, but need to be structured to balance the allocation of risk and return. Tilting too far in favor of the private investors leads to higher-than-market returns, yet failure to provide adequate return for the risks involved will defeat the objective as private investors will not be attracted.

Power generation may be one of the most promising areas for policy measures to enhance the viability of green projects. Power plants are relatively standardized compared to, for instance, mass transit, leading to greater homogeneity. This leads to a well-established approach to identifying and assessing risk, and an ability to look to a range of generally comparable projects when negotiating the allocation of risks and the financing package. All of this supports the use of project financing structures, which are already prevalent in conventional power generation.

Programs such as preferential feed-in tariffs have been revisited in many countries after initial introduction in order to address concerns that the balance of risks and rewards had been tipped too far in favor of investors in renewable energy. Typically, the guaranteed period and premiums for renewable energy have been reduced or limits have been imposed on the amounts that will be purchased at preferential rates, along with more stringent application and approval processes to become an approved renewable energy provider.

Design and administration of tax incentives is challenging, requiring balancing of the fiscal, administrative, and compliance costs with the expected benefits. This approach also requires extensive resources for policy development, which is essential to avoid unintended consequences. Tax incentives intended to promote the viability of green projects are more likely to lead to incremental green investment than tax incentives targeted specifically at green bonds through either issuers or investors. Making more projects financially viable will increase overall green investment, while incentives for green bonds may only result in green financing for projects that would have been funded by the private sector without the incentive.

The potential benefits and costs of tax incentives for green projects must be carefully considered in the context of national priorities and fiscal regimes. It is also important to draw on national and regional experience to ensure that the potential pitfalls and possible mitigation measures are addressed in the design of incentive programs. Applicability will be dependent on the fiscal position and policies priorities of individual countries.

\section{Policy Framework for Green Bonds}

Green bond markets in Europe and North America emerged in the absence of detailed national policy frameworks for green bonds. Instead, their development was largely an industry-led effort by institutional investors, underwriters, and issuers, who were responding to societal demands on companies and investors to address ESG factors 
in their activities. With these factors much less pronounced in ASEAN +3 , the nearterm development of local currency green bond markets must be led by governments. Experience in the PRC shows the importance of an appropriate policy framework to the growth of green bond markets.

\section{Embedding Green Bond Markets in National Policy Goals}

Efforts to promote the development of green bond markets will have greater priority with government officials and market participants if green bond markets are nested in broader national objectives. All ASEAN +3 countries are signatories of the Paris Agreement. Article 4 of the Paris Agreement requires countries to prepare and communicate the NDCs that set out their commitments to address the challenges of climate change, including targets and mechanisms to reduce carbon emissions. ${ }^{106}$ All ASEAN +3 countries (except Myanmar) have ratified the Paris Agreement, and all but Myanmar and the Philippines have filed NDCs with the UN. To meet their NDC commitments, countries will need to put in place a comprehensive set of policies aimed at reducing carbon emissions. A credible policy framework would include details on how measures to reduce carbon emissions will be financed. Green bonds are one of the mechanisms available to fund these activities.

Plans for a green bond market in the PRC had been announced in 2013 as part of the objectives of the 12th Five-Year Plan to transition to a low-carbon green economy. The CBRC began to systematically collect green financing data with the 2013 issuance of the Green Credit Reporting Instructions, which followed its 2012 Green Credit Guidelines. A green finance task force was established in 2014, whic published the report Establishing China's Green Financial System in April 2015. This led to the establishment of the Green Finance Committee, led by the People's Bank of China (PBOC) and with the participation of senior officials regulatory authorities, the financial sector, and academia.

The PBOC published its green bond guidelines for the interbank market in December 2015 (Green Finance Bond Announcement No. 39), followed immediately by the Green Finance Committee's (GFC) China Green Bond Endorsed Project Catalogue. Also, in 2015, the NDRC published Guidelines for the Issuance of Green Bonds, applicable to the state-owned enterprises subject to its oversight. These were followed in 2016 by guidelines for companies listed on the Shanghai and Shenzhen stock exchanges, and the CSRC's Guidance on the Development of Green Bonds Announcement No. 6. In March 2017, NAFMII issued the Non-financial Enterprises Green Debt Financing Instruments Guideline, applicable to nonfinancial issuers in the interbank market.

ASEAN +3 governments could consider linking the development of green bond markets to national climate change and/or sustainable development policies. When such policies have been established and the supporting role that green bond markets play is understood, then embedding efforts to promote green bond markets in a broader policy framework can be readily achieved.

06 Most of the NDCs filed to date follow the Intended Nationally Determined Contributions prepared in advance of the 21st Conference of the Parties to the UN Framework Convention on Climate, where the Paris Agreement was adopted. 


\section{Regulatory Framework}

Defining green bonds and prescribing a regulatory framework can serve two purposes. In markets such as Europe where the growth of the market has been investor-driven, clear standards regarding what is or is not green, and reporting obligations, can help investors make informed investing decisions and monitor the effectiveness of their green investments, enhancing market discipline.

In jurisdictions where green bond development has not been led by market participants, regulatory requirements for sustainability reporting by issuers and disclosures of the application of responsible investment practices by institutional investors can help to raise awareness of green bonds and potentially stimulate supply and demand. Prudential authorities can require climate change and other environmental risks be explicitly addressed by regulated institutions such as banks. If policy makers intend to provide incentives to spur market development, a regulatory definition and prescribed requirements for issuers will be required to prevent abuse.

Policy makers can choose to leave the green bond market unregulated and marketdetermined, as it currently is in all countries except the PRC and India, or adopt a specific green bond regulatory framework including a green bond definition. The type of regulatory framework for green bonds, if one is adopted, should be consistent with the broader approach to capital market regulation. Securities regulators and self-regulatory organizations (SROs) such as stock exchanges can introduce mandatory disclosure requirements for listed companies and institutional investors. Prudential authorities can ensure that climate change and environmental risks are explicitly addressed in risk management processes and capital allocation.

In the PRC, green bond requirements are incorporated into the merit-review process required for all applications for bond issuance. ${ }^{107}$ The market in the PRC is segmented by type of issuer, with different authorities responsible for different parts of the market. Although the requirements of each regulator vary somewhat, the common elements are a definition of green bonds based on use-of-funds categories broadly similar to the GBP, supplemented by a more detailed project catalogue. There are also specific issuer requirements with respect to green bond frameworks and reporting, which are reviewed by the relevant authorities prior to providing approval for bond issuance.

In the case of India, the green bond requirements emphasize disclosure. There are detailed and specific listing, filing, and disclosure requirements that must be met prior to issuance of any debt securities in India, but there is no ruling or decision on the merits of the issue by a regulatory authority. Green debt securities are defined on the basis of use of proceeds, with categories that are consistent with the GBP. The SEBI has the power to deem additional green categories. Issuers of green debt securities are required to meet additional requirements beyond those applicable to other debt securities. These include initial and

107 A merit-review process requires issuers to demonstrate their ability to repay their debt obligations to the satisfaction of the regulator. The PRC is unique among ASEAN +3 countries with an established corporate bond market that uses a merit-review process. 
continuing disclosure standards with respect to project selection criteria, tracking the use of funds, and performance indicators.

The development of green bond markets in Europe illustrates that there is not necessarily a need for a specific regulatory framework for green bonds-a legal foundation and market oversight that facilitates innovation can be sufficient. However, the credibility of green labeling is crucial to the market, especially as many investors lack the expertise or resources to conduct their own assessments of the greenness of a bond.

Given the various combinations of definitions and verifications of green that exist in the market (Box 3), there is a lack of clarity that may discourage green issuance-issuers will not want to incur the expense of a green issue only to have it not accepted as such by key market participants. Similarly, investors want to minimize their costs by relying on a credible green label. A number of market participants in several ASEAN countries expressed interest in a regulatory determination of what is green.

A regulatory definition of green and requirements for initial and ongoing reporting by issuers could provide greater clarity. Even with a regulatory requirement, however, the definition of green will require interpretation unless the regulatory definition is exclusive-only types of projects specifically listed would qualify. This potentially discourages innovation by excluding types of projects that may not have been considered or technologies that had not yet come to market when the regulation was drafted, but would still have a positive impact on sustainable development. An inclusive rather than exclusive definition of green provides greater flexibility and accommodation of innovation. An exclusive definition would also likely require the establishment of an adjudication process for issuers to appeal rejections by the regulator of their request for a green bond label.

Criteria other than self-labeling to define a green bond would be required to avoid abuses of any incentives that may be provided to green bond issuers and investors. This could be done in the context of individual policy interventions, but it could also be useful and potentially reduce policy development costs to have a common definition of green projects, recognizing that bonds are only one option for the financing of green projects. Within the umbrella of a definition of green projects, green bonds would be defined in line with the $\mathrm{GBP}$ as instruments with proceeds dedicated to green projects.

Prescribed reporting and disclosure standards will add to compliance costs for issuers and investors that are not already voluntarily making such disclosures. Even for issuers and investors voluntarily making such disclosures, there may be a cost to meet standardized requirements prescribed by regulation.

Frameworks based on the GBP facilitate alignment with regional and international standards. The approach in the PRC of guidelines based on the GBP supplemented by a green project catalogue can be considered as a means of providing more detailed guidance, but would not be required to have an operational regulatory framework. At least initially, disclosure and reporting requirements would not need to be more detailed than provided in the GBP. Over time, the merits of introducing additional or more detailed requirements (e.g., with respect to actual emissions reductions achieved) could be considered. 


\section{Box 3: Is That Bond Green?}

Many self-labeled green bonds are accepted as such by all or most market participants. Some, but not all, selflabeled bonds have second opinions to substantiate their greenness.

The GBP, the most widely used international yardstick for green labeling, provide high-level guidance, but must be interpreted in the context of individual issues. Green bonds issued prior to the April 2014 promulgation of the GBP were necessarily self-labeled, or retroactively labeled, as green.

The practice of using an external party to provide an opinion on the green label predates the adoption of the GBP and has grown steadily, but is not universal. Close to one-third of tranches reported by CBI in 2016 do not have a second opinion.

The CBI Standard provides a more detailed taxonomy of green projects and has more detailed assessment criteria for some types of green project, but even when complete the CBI Standard is not intended to be exhaustive.

Moody's and S\&P Global Ratings have introduced rating criteria for the greenness of a bond, separate from their credit rating methodologies.

The PRC and India have national definitions of green bonds, but globally the vast majority of issues are self-labeled. This has led to a range of definitions of green with both external and market-determined verification of a bond's greenness.

Key market participants may differ on whether a specific bond is green. Spanish oil refiner Repsol issued a $€ 500$ million bond in April 2017 with a second opinion by Vigeo Eiris, a respected provider of second opinions, confirming that the issue made a positive contribution to sustainable development and was aligned with the GBP. The issue is coded as green in the Bloomberg database, but excluded from the CBI green bond database on the grounds that incremental improvements in fossil fuel refining make an insufficient contribution to reducing emissions. It has also been excluded from the major global green bond indices.

\begin{tabular}{l|l}
$\begin{array}{l}\text { Green Definition and Verification } \\
\text { Self-labeled, self-assessed }\end{array}$ & \multicolumn{1}{c}{ Example } \\
\hline Self-labeled, second opinion & European Investment Bank 2007 \\
\hline Green bond principles, self-assessed & World Bank 2008, CICERO \\
\hline Green bond principles, second opinion & Nordic Investment Bank 2014 \\
\hline Climate bonds standard and certification & Asian Development Bank 2015, CICERO \\
\hline National definition, self-assessed & Big60Million Solar Bond 2014 Bureau Veritas \\
\hline National definition, second opinion & $\begin{array}{l}\text { Securities and Exchange Board (India) } \\
\text { requirements (May 2017) make a second } \\
\text { opinion optional }\end{array}$ \\
\hline National definition, regulator assessed & $\begin{array}{l}\text { Bank of Quingdao (China Banking Regulatory } \\
\text { Commission guidelines) 2016, Ernst and Young }\end{array}$ \\
\hline
\end{tabular}

$\mathrm{CBI}=$ Climate Bonds Initiative, $\mathrm{CICERO}=$ Climate and Environmental Research, GBP = Green Bond Principles, NDRC = National Development and Reform Committee, PRC = People's Republic of China, S\&P = Standard \& Poor's.

Sources: Asian Development Bank, Bank of Quingdao, Climate Bonds Initiative, European Investment Bank, Nordic Investment Bank, Securities and Exchange Board (India), Vigeo Eiris, and World Bank. 


\section{Expanding the Supply of Green Bonds}

When the preconditions for local currency bond markets and infrastructure financing more generally are in place, targeted interventions to support the issuance of green bonds can be considered. Because green bonds are more expensive to issue than conventional bonds, the goal of most supply-oriented polices is to lower issuance costs. Expanding supply is more important than stimulating demand because of the large unmet demand for fixed income securities, especially corporate issues, from large institutional investors in ASEAN+3 countries. Green bonds have similar structures, terms and yields to conventional bonds. While investors with responsible investment mandates are rare in ASEAN+3 countries, the experience in the PRC indicates that domestic institutional investors are willing to purchase green bonds and thus greater supply will be easily absorbed by the market.

\section{Public Sector Issuance of Green Bonds}

The lack of supply of green bonds in many countries keeps awareness of green bonds low and discourages investment banks from developing green bond underwriting capabilities and institutional investors from developing green bond assessment skills. Public issuance expands the supply of local currency green bonds, provides a demonstration effect about how green bonds are issued, and signals the importance of green bonds to national policy objectives. A large issue will also be effective in focusing domestic institutional investors on green bonds.

Many public sector entities - such as national and subnational governments, development banks, export credit agencies, public utilities, and other state-owned enterprises-are engaged in at least some activities that would satisfy use-of-proceeds eligibility criteria and thus could be funded through a green bond issue. Once suitable entities are identified, the government could require that they issue a green bond or provide incentives for them to do so, such as a one-time grant to offset the cost of developing green bond issuance capabilities.

Through the middle of 2017, public issuance of green bonds in ASEAN+3 countries was limited to the PRC (many examples), Japan (Development Bank of Japan), and the Republic of Korea (Export-Import Bank of Korea and the Korea Development Bank). In the case of the public issues in Japan and the Republic of Korea, the local demonstration effect may have been modest because the green bonds were issued in foreign currencies and were largely bought by foreign investors. There are opportunities for government and government-related entities throughout ASEAN +3 to consider green bond issuance.

\section{Credit Enhancements}

Credit enhancements are commonly used to mitigate some of the risks in infrastructure financing, increasing the attractiveness to private sector investors, reducing financing costs, and thus enhancing the financial viability of the project.

Credit enhancements can include partial or full guarantees as well as junior debt or equity investments to provide additional comfort to senior debt holders. The main providers of credit enhancements in the ASEAN+3 region are export credit agencies that provide 
support for their country's manufacturers and contractors in international projects, development banks, government agencies, and the MDBs. Monoline insurers specializing in guarantees (wraps) for bond issues were never very active in the region, and worldwide have become much less prominent in the wake of losses incurred during the global financial crisis.

There are currently no green-bond-dedicated credit enhancement facilities, although existing providers are generally able to accommodate green projects. A number of countries across ASEAN +3 have established entities to provide credit enhancement both specifically for infrastructure projects and for private sector financing more generally. Although none of the credit enhancement providers in ASEAN +3 has a dedicated green portfolio, each could be used equally well to support green projects.

Credit enhancement facilities within ASEAN +3 include the Korea Infrastructure Credit Guarantee Fund, established in 1994 to guarantee bank loans and infrastructure bonds. The Indonesian Infrastructure Guarantee Facility is targeted at infrastructure and includes political risk insurance in its product portfolio. Malaysia's Danajamin includes a portion of infrastructure-related companies and projects in its portfolio.

Credit enhancement through guarantees, or investment in an equity or junior debt financing tranche offers the potential to lever an initial investment across a number of projects. However, the need to maintain a high credit rating so that the guarantee provides the expected rating uplift limits leverage. Experience in ASEAN+3 with Danajamin and the Indonesian Infrastructure Guarantee Facility shows that it takes several years to build a portfolio, both because of the time required to establish operational and risk management structures, and because of the time required to bring projects to the financing stage.

Building on existing credit enhancement facilities is likely a preferred option as it levers the investments already made in governance, risk management, and operational capacity, thus offering economies of scale and scope. This should facilitate faster and more cost-effective credit enhancement for green projects relative to a start-up facility targeted solely at the green market. Recognizing that some investors may be attracted specifically by the green aspect, existing credit enhancement vehicles could operate a green fund segregated from the general fund, using investment criteria consistent with the GBP.

\section{Securitization}

Securitization offers the potential to finance green assets that are too small or with too low a credit rating to attract direct green bond financing. Debt obligations can be pooled in a special purpose vehicle (SPV), which in turn issues securities backed by the cash flows from the underlying debt obligations. This provides the necessary larger issue size, as investors purchase the securities issued by the SPV rather than individual projects. There is also the possibility that the SPV may issue different tranches of securities. Through the use of internal credit enhancements such as cash reserve funds and overcollateralization, as well as external credit enhancements, these tranches could have a range of credit ratings to suit the risk appetite of different investors. 
Securitizations can be used for a range of underlying assets. Consumer obligations such as auto loans and mortgages, which are commonly securitized in the US, are good candidates for green securitization. An SPV might purchase bank or other green project loans. The purchase of project bonds facilitates standardized contract terms and conditions for the underlying securities as these can be prescribed by the SPV.

Heterogeneity of underlying assets is an obstacle to securitization - where broad and deep securitization markets have developed, such as residential mortgage-backed securities, they have been supported by standardized contracts and readily available qualifying criteria such as loan-to-value ratios and credit scores. The largest issuer to date of green ABS, Toyota Financial Services, used auto loans and leases, which are highly standardized, collateralized by liens on or retention of ownership of vehicles, and subject to internal credit adjudication criteria.

The preconditions for securitization of green assets are the same as for any securitization. These include an enabling legal framework, an ecosystem of trustees for SPVs, legal and investment counsel, managers and servicers of the SPV, ratings agencies, and tax neutrality. In the context of securitization, tax neutrality means that the securitization transaction does not lead to any additional tax liabilities for the entity selling debt obligations to the SPV, or the SPV itself, other than those that would have applied had the securitization not taken place. Jurisdictions such as Malaysia and Singapore that have sought to promote securitization have specific provisions including a "flow-through" treatment so that the SPV is not subject to income tax. An additional precondition with respect to green securitization is a pipeline of qualifying assets.

If the preconditions are in place, specific policy interventions can be considered to promote securitization more generally and green securitization in particular. Standardized contracts for types of green assets (e.g., consumer loans for energy retrofitting of houses, mortgages on green certified properties, and common projects such as solar installations) provide the foundation of instruments that can be readily pooled. Existing credit guarantee agencies could provide external credit enhancements to support securitization. Where private interest may not be present, government-owned development banks might play the warehousing role, accumulating green assets until the critical mass required by an SPV has been created. Government-related investors such as national pension funds can play a catalytic role in purchasing initial $A B S$ issues.

The PACE program is open to US homeowners and owners of commercial, industrial, nonprofit, and agricultural properties in participating jurisdictions to finance a green upgrade to their property. Private companies administer most PACE programs, with local governments typically setting guidelines and policies, including eligibility criteria, fee structures, and interest rates. Cost of the upgrade is repaid over a term that may be up to 30 years, with the collateral for the loan being an assessment or special tax levied on the property by the municipality. Since taxes owed must be paid prior to transfer of ownership, and municipalities can and do seize and sell properties to recover unpaid taxes, PACE loans are viewed as having collateral and risk characteristics similar to residential mortgages. This facilitated PACE securitizations in the well-developed ABS market in the US. Total PACE 
financing at the end of 2016 was $\$ 3.4$ billion, ${ }^{108}$ with three of the largest PACE originatorsRenovate America, Ygrene Energy Fund, and Renew Financial having sponsored almost $\$ 1.6$ billion in PACE securitizations in 2016. ${ }^{109}$

The Warehouse for Energy Efficiency Loans (WHEEL) program is a collaboration among US financial market participants and governments and agencies to promote small-scale retail lending to retrofit homes for greater energy efficiency. Citibank provides the financial support to warehouse loans pending issuance of $A B S$, helping to address the challenge of establishing a pipeline of assets and providing immediate purchase of assets pending accumulation of a sufficient volume for securitization.

The Mega Solar Project Bond Trust provides project bond financing to solar plants in Japan. The trust purchases bonds of individual solar projects, in turn issuing its own securities backed by the project bonds. The securities are typically purchased by domestic institutional investors who may not have the expertise to assess the risks and invest directly in individual projects. Solar installations are relatively standard, lending themselves more readily to securitization.

Securitization offers the potential to expand the supply of green bonds through the creation of $A B S$ and to use capital market funding for smaller projects that would not attract direct interest in bonds. However, green securitization will not take off unless the more general preconditions for securitization are in place. Where these are in place, governments may wish to encourage green securitization as a means of attracting capital market funding for projects that may either be too small or lack a suitable credit rating for individual green bond issuance.

In a number of ASEAN+3 countries, banks are generally liquid, and the originate-todistribute model underpinning the US securitization market has not been established. ASEAN +3 banks may find general obligation green bonds, where they use bond proceeds to finance or refinance identified green assets, a more effective option than attempting to securitize the assets.

It would be difficult to replicate the US PACE and WHEEL programs in other countries without adaptation. A feasibility study concluded that in a number of countries there may be challenges in identifying all of the necessary partners, or the ecosystem needed for securitization-originators, servicers, servicing mechanism, source of capital and credit enhancement, and the necessary legal expertise-quite apart from the pipeline of green assets. ${ }^{110}$ The US underwriting model, heavily reliant on readily available numerical credit scores, generally could not be replicated. In most cases, considerable upfront investment and several years at least would be required to address these challenges and bring green securitizations to market.

108 Morningstar. 2017. Clearing the Air: Addressing the Misconceptions of PACE. http://pacenation.us/wp-content/ uploads/2017/03/morningstar-addressing-misconceptions-pace.pdf.

109 TMF Group. 2017. PACE Securitization Market on the Rise. https://www.tmf-group.com/en/news-insights/articles/2017/ may/us-pace-securitization-market/.

110 Energy Programs Consortium. 2017. WHEEL Feasibility Study: India, China, Brazil, UK, and the EU. https://www greenfinancelac.org/esi/publication/the-warehouse-for-energy-efficiency-loans-wheel-feasibility-study-india-china -brazil-uk-and-the-eu/. 
In the near- to medium-term, banks and other green asset originators will probably find it easier and less costly to issue general obligation green bonds. In the medium- to longerterm, government-related entities such as Cagamas, the Malaysian national mortgage corporation, might play a pioneering role in issuing green mortgage-backed securities.

\section{Advisory Services for Issuers}

A lack of experience in issuing green bonds creates uncertainty about what types of projects and assets qualify as green, and how to structure a green bond issue. This uncertainty holds back supply. It also adds to the cost of issuance since issuers must acquire this knowledge before issuing a green bond. Advisory services overcome this uncertainty and lower issuance costs by guiding issuers and underwriters on the process of issuing green bonds.

Advisory services require green bond experts to work directly with treasury professionals and investment bankers to structure a green bond issue. Advisory services enhance the capacity of the issuer and underwriter for subsequent green bond issues. ADB worked closely with Aboitiz Power Corporation, the parent of AP Renewables, in the inaugural Philippines green bond issue. As part of a larger financing package, ADB experts supported work on the green bond framework and reporting structure, and hired and worked with the external reviewer in the preparation of their second opinion. Both the issuer and the underwriter credit ADB's assistance in the successful structuring of the green bond. Another example is the IFC. As part of its partnership with Amundi to set up a $\$ 2$ billion green bond fund, the IFC has established a dedicated team to provide training and technical support to assist financial institutions in emerging markets to issue green bonds. ${ }^{11}$

\section{Grants for the Payment of External Reviews}

Many issuers (and potential issuers) see green bonds as costlier to issue than conventional bonds due to the added work involved in preparing the green bond framework, tracking the use of proceeds, post-issuance reporting, and the cost of securing an external review. While green bonds offer several benefits to issuers including expanding the potential investor base and demonstrating commitment to ESG and environmental issues, they are often not convinced that the value of these benefits exceeds the added cost. Programs to lessen the cost of green bond issuance will make them a more attractive option for issuers.

A grant program for external reviews could pay the cost of a second opinion, third-party verification, or a green rating. Administrative costs could be minimized by establishing clear criteria for eligible expenses. Because external reviews are only one component of the additional cost of issuing a green bond, and for first-time issuers perhaps not even the largest one, a grant program is not a game changer. It would nevertheless encourage green bonds by lessening overall issuance costs and by raising awareness of green bonds and signaling their importance in the support of national objectives. The MAS grant program in Singapore, announced in June 2017, is an example from ASEAN that may be relevant for some jurisdictions.

11 C. Flood. 2017. IFC Invests $\$ 325 \mathrm{~m}$ in Green Bond Fund for Emerging Markets. Financial Times. 21 April. 


\section{Mandatory Environment, Social, and Governance Reporting by Issuers}

A lack of comprehensive reporting on the ESG activities and impacts of issuers makes it difficult for institutional investors, individuals, and civil society organizations to monitor the performance of issuers on ESG measures. Mandatory reporting of ESG activities and impacts would make them more transparent to market participants, thereby increasing the importance of reputational considerations to issuers. This would encourage issuers to become more involved in activities with positive environmental and social impacts, which increases opportunities for companies to issue green bonds and the benefits from doing so. Mandatory reporting on environmental activities and impacts could reduce the incremental cost of issuing green bonds by making data needed for ongoing reporting more readily available.

ESG reporting is intended to inform investors about issuers' nonfinancial risks. There are many potential measures, with the most important environmental ones being energy use, carbon emissions, water use, and waste generation. Reporting on ESG measures may be mandated as a listing requirement by securities exchanges or as a government policy. The reporting requirement may be principles-based, requiring issuers to report on only those measures that it believes are material risk factors, or rules-based, where companies are required to report on prescribed measures. Mandated reporting on ESG measures must usually be provided on an annual basis.

Twelve securities exchanges require ESG reporting as part of their listing rules, including Bursa Malaysia, the Singapore Exchange, the Stock Exchange of Thailand, and the Ho Chi Minh Stock Exchange. ${ }^{112}$ Companies listed on the Main Market of Bursa Malaysia are required to disclose a narrative statement on the management of material economic, environmental, and social risks in their annual reports. This requirement takes a principlesbased approach, although Bursa Malaysia has also issued a Sustainable Reporting Guide and Sustainable Toolkits that provide best practices on the type of information to be reported and the reporting format. Another example is the recommendations of the Financial Stability Board's Task Force on Climate-Related Financial Disclosure. ${ }^{113}$ Among its many recommendations is a call for organizations to disclose the metrics they use to assess climate change-related risks and opportunities, and to disclose their actual greenhouse gas emissions.

Establishing mandatory ESG reporting requirements can be costly for issuers. Principlebased requirements are generally less costly because management chooses what to report. This tends to result in less comprehensive reporting and greater variability in the quality of information that is disclosed. Minimum mandatory reporting requirements yield better results. ${ }^{114}$ However, mandatory reporting also tends to be costlier for issuers because it may require them to collect data on activities that were not previously collected. Focusing on a few key indicators such as carbon emissions helps to contain reporting costs. Consistency

Table 1 of Sustainable Stock Exchange Initiative. 2017. Report on Progress, 2016. http://www.sseinitiative.org/.

113 Task Force on Climate-Related Financial Disclosures. 2017. Final Report: Recommendations of the Task Force on ClimateRelated Financial Disclosures. https://www.fsb-tcfd.org/.

114 Corporate Knights. 2016. Measuring Sustainability Disclosure: Ranking the World’s Stock Exchanges. p. 5. http://www .corporateknights.com/reports/2017-world-stock-exchanges/. 
with international standards and best practices can ensure that the data is comparable across countries.

\section{Tax Incentives for Issuers}

Reducing the after-tax costs of green bonds relative to other financing sources would make them more attractive to issuers. Issuers could receive a tax credit or reduction in rate or exemption from taxes for projects financed with green bonds, or a direct cash subsidy to offset the cost of the bond. Possible options are listed below:

(i) a credit, in addition to any prevailing ability to deduct bond interest and issuance expenses from income, which can be used to reduce other taxes payable by the issuer;

(ii) a reduction in the rate of or an exemption from value-added tax on inputs, or payroll and social taxes for projects financed by green bonds;

(iii) refundable tax credits for some or all incremental costs of green bond issuance; and

(iv) refundable tax credits or direct cash subsidies for some of the interest costs of green bonds.

A Qualified Energy Conservation Bond enables qualified US state, tribal, and local government issuers to obtain a federal government interest rate subsidy, or alternatively, to structure the bond so that investors receive a tax credit. Under the subsidy program, the issuer receives $70 \%$ of the coupon rate from the federal government, with the interest, unlike conventional municipal bonds in the US, which are exempt from income tax, being fully taxable in the hands of investors. This allows issuers to take advantage of the much larger general corporate bond market rather than being limited to the smaller tax-exempt market, potentially broadening the investor base.

Tax credits or subsidies for issuers are likely to encourage issuance. However, incentives may also have a distortive effect by encouraging the use of one type of financing, for example project bonds, purely to take advantage of the tax incentive. In such a case, the tax incentive would not contribute to financing a green project that would otherwise not be completed, but rather shifts the financing from, for example, syndicated bank lending to green bonds.

The US Qualified Energy Conservation Bond program transfers costs from subnational government entities to the federal government. Overall costs to the taxpayer are higher by the amount of the administrative costs of the program; however, it does provide a mechanism to transfer costs from levels of government with narrower tax bases to the larger tax base of the federal government.

Exemptions from specific taxes or applications of favorable rates are challenging to administer. Although they do have the potential to improve the financial viability of a project, defining eligibility and enforcing criteria can be resource-intensive and costly in such programs. 
Tax incentives for issuers of green bonds run the risk of merely promoting one type of financing without increasing overall green investment and creating a green bond market that is dependent on incentives. The broader objective should be to increase the number of green projects that are financed. Incentives need to be carefully weighed against the costs, and if pursued would be better targeted to green projects to improve their financial viability than to the issuers of green bonds.

\section{E. Facilitating Demand for Green Bonds}

The long-term sustainability of any market requires a balance between supply and demand. At present, there is little explicit demand for local currency green bonds by institutional investors in ASEAN+3 countries. Market participants indicated that while institutional investors outside the region have shown interest in green bonds issued in US dollars and euros, their interest in local currency green bonds is limited. This would seem to suggest that stimulating demand for local currency green bonds is an urgent priority.

Yet, this is not the case. While domestic institutional investors in ASEAN+3 countries are not explicitly seeking green bonds, they do have strong demand for fixed income securities, especially highly rated corporate bonds. Because green bonds are similar in structure, term, and yield to conventional bonds, placing them with institutional investors will not be a challenge. Demand-oriented policies should be pursued, but given the nascent stage of local currency green bond markets in most ASEAN +3 countries, these policies are of less urgency than putting in place a policy framework for green bonds and policies to encourage the issuance of green bonds.

\section{Public Sector Investment in Green Bonds}

Commitments by public investors to allocate part of their portfolio to green bonds would encourage borrowers to issue green bonds knowing there is demand specifically for green bonds. Public investors also help the green bond market to develop through their investment policies on the type and structure of green bonds that they will hold.

Public sector investment in green bonds can take two forms. The first is for existing public funds, such as national pension plans or sovereign wealth funds, to commit a portion of their fixed income portfolios to local currency green bonds. This will often involve a change in a fund's investment policy by establishing an explicit mandate to green bonds or for the fund to consider ESG factors in its investment decisions. An explicit commitment to green bonds needs to specify an amount (percentage of portfolio or value) and a target implementation date. The commitment may also state any preferences regarding the type of green bonds sought (e.g., minimum issue size, sector, and currency) or other features (e.g., a second opinion).

A second approach is to establish a dedicated green bond fund, which could be funded directly by the government or via commitments from public investment funds. Management of a green bond fund could be placed with an existing public sector fund or could be outsourced to a private fund manager with expertise in green bonds. 
An example of this second approach is the Clean Energy Finance Corporation (CEFC) established in Australia in 2012. It is a government-owned green bank that invests in the clean energy sector through a variety of financing mechanisms, including green bonds. As of March 2017, the CEFC had invested in six green bonds issued by Australian entities, with a combined value of $\mathrm{A} \$ 325$ million. For each issue, the CEFC served as a "cornerstone" or "anchor" investor, signaling to the issuer and other investors that there was demand for the issue. ${ }^{115}$

The less resource-intensive option is for existing public funds such as pension plans and sovereign wealth funds to commit to investing in local currency green bonds. Funds that have already committed to including ESG factors in their investment process, such as those who are signatories to the United Nations Principles for Responsible Investment (UNPRI), are likely to be the most receptive. ${ }^{116}$

\section{Mandatory ESG Reporting by Institutional Investors}

Mandatory reporting on ESG exposures could increase the demand for green bonds in two ways. First, ESG reporting makes portfolio managers more aware of the benefits of investments with positive environmental impacts and the risks associated with those that do not. ${ }^{117}$ Second, institutional investors not seen to be managing their environmental risk exposures effectively may be pressured by clients and civil society organizations to explain their actions and to alter their behavior. With respect to environmental risks, the key disclosure items are the carbon intensity, energy and water usage, and waste generation of portfolio holdings. ESG disclosure requirements can be set in the legislation or regulations governing asset owners and their investment managers.

In Ontario, Canada's largest province by population, pension plans are required to disclose information about whether ESG factors are incorporated into their investment policies and, if so, how it is integrated into their investment strategies. This information must be filed annually with pension regulators and is available to the public. While the rules do not require pension plans to consider ESG factors in their investment strategies, the widely held view among Canadian pension experts is that dismissing ESG factors is not consistent with the fiduciary responsibility of trustees. ${ }^{118}$

Establishing mandatory ESG reporting can be very costly to institutional investors. Effective management of and reporting on ESG risk exposures requires comprehensive data on each holding in a portfolio, which for larger institutional investors will exceed several thousand names. External data providers exist to provide this information. Done effectively, it also requires changes to investment management processes, including those of outside

\footnotetext{
CEFC. 2017. CEFC Press Release. 29 March.

116 As of 30 June 2017, four public funds in ASEAN+3 countries were UNPRI signatories: the Government Pension Investment Fund and the Development Bank of Japan (Japan), Khazanah National Berhad (Malaysia), and the National Pension Service (Republic of Korea).

117 For instance, the Economist Intelligence Unit estimates that the value at risk for investment assets is between $\$ 4.2$ trillion and $\$ 43.0$ trillion. Economist Intelligence Unit. 2015. The Cost of Inaction: Recognizing the Value at Risk from Climate Change. London.

118 See, for instance, D. Rienzo. 2014. New Ontario Requirements for SIPPS and Retiree Pension Statements. https://www .osler.com/en/resources/regulations/2014/new-ontario-requirements-for-sipps-and-retiree-pen.
} 
managers. The cost of ESG reporting will decline as the number of issuers providing ESG data increases and there is greater standardization of reporting formats.

\section{Capacity Building for Institutional Investors in ESG Analysis}

Exposing investment managers to the fundamentals of ESG analysis could increase their interest in green bonds and their ability to assess them. Capacity building requires training of investment professionals in ESG risk exposure analysis, the valuation implications of ESG factors on securities pricing, the impact of positive and negative screening on portfolio construction, and the integration of ESG analysis into portfolio construction. Training can be provided through workshops led by experienced ESG analysts and by the publication of how-to materials. ESG training is usually provided by professional accreditation organizations, local investment management associations, or as part of the local licensing process for investment managers.

The CFA Institute, the premier training organization for investment management professionals, offers a wide range of training programs and materials on ESG analysis. They include an e-learning module on ESG analysis, a guide on ESG analysis for investment professionals, and regulator coverage of ESG issues in CFA publications and at CFA conferences. ESG analysis is also part of the core curriculum leading to the CFA designation.

Low-cost training programs and materials on ESG analysis are readily available. The take-up of training opportunities could be increased by requiring knowledge of ESG analysis as a licensing or continuing education requirement for investment managers.

\section{Tax Incentives for Investors}

Better after-tax returns relative to other bonds or comparable investments would make green bonds attractive to investors. Tax incentives for investors can take the form of tax credits, deductions from taxable income, favorable tax rates, or full exemption from tax. These can include the following:

(i) credits for investment in green bonds that can be used to reduce tax payable on income from eligible bonds or income more broadly,

(ii) deduction of income from eligible bonds from income for tax purposes,

(iii) reduced tax rates on income from eligible bonds, and

(iv) exemptions from specific taxes such as stamp duty and capital gains tax.

The incentives could be targeted specifically at green bonds, or be part of broader programs to promote infrastructure financing or bond markets more generally.

Clean Renewable Energy Bonds (CREBs), which may be issued to finance renewable energy projects by qualifying US electric cooperatives, subnational government entities, and certain lenders, provide the bondholder with federal tax credits in lieu of a portion of traditional bond interest. These credits can reduce the federal tax taxable by the bondholder, increasing after-tax income. While the tax credit provides a financial benefit to the bondholder, they are effectively a federal government subsidy to the issuer as CREBs 
bear a lower coupon rate relative to conventional bonds, thus reducing the cash cost to the issuer relative to conventional bonds.

Indian tax-saving infrastructure bonds provide a tax deduction for investors. Targeted at individual investors, amounts up to ₹20,000 (\$315) invested in eligible infrastructure bonds may be deducted from taxable income. Interest income from the bonds is included in the bondholder's taxable income and taxed at the relevant marginal rate. Qualifying infrastructure bonds may be issued by eligible quasi-sovereign entities and nonbank financial institutions designated by the Reserve Bank of India. Individual investors are encouraged to direct savings to infrastructure investment, providing non-budget financing for quasi-sovereign entities. Fiscal costs are minimized by the low limit; however, the administrative costs for issuers related to the ₹5,000 (\$77) typical certificate value are significant. The program may also contribute to broader bond market development by attracting individuals who might not otherwise consider investing in bonds.

Brazil infrastructure debentures were introduced in 2011, providing investors with taxexempt income from bonds issued to finance priority infrastructure projects. Through 2016 there had been 68 issues totaling BRL18.3 billion ( $\$ 5.6$ billion), of which about one-third were for renewable energy. ${ }^{119}$ About $45 \%$ were held directly by individual investors, with significant retail investment also taking place through mutual funds that invest in the infrastructure debentures.

Malaysia has employed a range of favorable tax treatments to encourage the growth of its bond and sukuk markets, which would be equally applicable to green bonds and sukuk. These include exemption for resident investors from income tax, and for foreign investors from withholding tax, on interest income from ringgit-denominated debt securities and sukuk, and foreign-currency-denominated sukuk issued in Malaysia. There is no stamp duty (transactions tax) on sales of securities, and there is no capital gains tax in Malaysia. ${ }^{20}$

The key questions are whether tax incentives for investors in green bonds would result in more green projects, and whether the benefits of the incremental green investment would offset the costs of the incentives. In addition to the fiscal cost of foregone tax revenue, there are administrative and enforcement costs for the tax authorities and compliance costs for taxpayers to consider.

Unlike in Brazil in 2011, there is no evidence in ASEAN+3 of a backlog of infrastructure projects, green or otherwise, awaiting financing. The much larger problem is getting projects through the preparation phase. Viable projects brought to market have a range of financing options available, including project bonds in some markets. Thus, the likely result would be ASEAN +3 institutional investors with unmet demand for high-quality bonds buying the green bonds of projects they would have been likely to invest in without incentives.

Incentives for investors should only be considered if there is evidence of viable projects unable to attract financing. The potentially high fiscal, administrative, and compliance costs

119 Terraco Economicio. http://terracoeconomico.com.br/debentures-incentivadas-de-infraestrutura-um-novo -modelo-de-financiamento (accessed 11 July 2017).

120 ADB. 2012. ASEAN+3 Bond Market Guide. Manila. 
of incentives - whether targeted at green bonds, infrastructure financing, or more general bond market development-need to be balanced against the expected benefits. Incentives that would improve the financial viability of green projects are likely to be more efficient in encouraging incremental green investment. The US CREB program, although structured as a tax credit for investors, has the effect of reducing the issuers' interest costs, thus improving the financial viability of the project.

Tax incentives could potentially lessen interest in green bonds among nontaxable investors, such as pension plans, who would not benefit from the incentive. Under certain conditions, taxable investors may accept a lower yield on eligible green bonds due to the tax incentive. Nontaxable investors would not since the tax incentive is of no value to them. In theory, this could drive nontaxable investors away from green bonds.

\section{Regulatory and Central Bank Policies for Green Bonds}

Demand for green bonds could be stimulated by preferred regulatory and central bank treatment relative to other bonds. There has been some policy discussion in Europe $\mathrm{e}^{121}$ and in $\mathrm{CBI}$ forums ${ }^{122}$ of relaxing prudential and financial stability standards to make green bonds more attractive investments for regulated deposit-taking institutions.

Three specific proposals are more favorable risk-weights, a more favorable leverage ratio, and preferential treatment for access to central bank liquidity facilities. In a similar vein, but without affecting the prudential standards for banks, are proposals to invest central bank reserves in green bonds and to exempt green bonds from capital controls.

All the proposed measures would make green bonds more attractive as investments relative to a conventional bond with otherwise similar characteristics. Lower risk-weights and allowance of higher leverage for green assets would reduce the capital that banks need to hold relative to other assets with similar risk characteristics. This would likely spur bank investment in green bonds as the higher leverage would increase returns to bank shareholders, albeit at the expense of greater volatility in returns. Similarly, if green bonds were accepted by central banks as eligible collateral for liquidity facilities, even if not meeting normal quality standards, there would be an incentive for banks to hold such securities.

Central banks typically invest reserves in a range of high-quality investments. Including green bonds in the investable universe potentially increases demand for green bonds. Different approaches to capital controls are in place across the region, ranging from full convertibility to few or extensive restrictions. Controls may be introduced or added as part of the policy toolkit to respond to volatile capital flows, as was the case in 2010 in Indonesia, the Republic of Korea, and Thailand. Exempting green bonds would certainly make them more attractive relative to bonds with otherwise similar characteristics.

121 A. Couchu et al. 2016. Study on the Potential of Green Bond Finance for Resource-Efficient Investments. Brussels: European Commission.

122 For example, CBI. The Future of Green Bonds Standards and Incentives. 2016. London. 
There are few, if any, examples of countries weakening their prudential frameworks or departing from international best practices in reserve management to promote the green bond market.

There are significant risks in adjusting prudential and financial stability standards to promote the green bond market. As outlined below, the existing international standards and best practices will recognize any demonstrable lower risk in a green bond relative to a non-green bond, and will accommodate use of green bonds as collateral for central bank borrowing or as eligible central bank reserve investments, provided they meet the more general requirements. Promoting green bonds at the expense of increased risk in the financial system is a policy trade-off unlikely to be acceptable to central banks and regulatory authorities.

Proponents of the lower risk weights for green bonds argue that they are less risky than conventional bonds. The majority of green bonds are general obligation bonds of issuers that also have similarly rated conventional issues. Since both the green and conventional issues are similarly reliant on the financial performance of the issuer, and rank pari passu in the hierarchy of creditor claims, it is difficult to attribute a superior risk profile to the green bond issue.

In terms of distinguishing between green and non-green issuers, any difference in creditworthiness should be captured in the credit rating and loss experience. In the Basel II standardized framework, if there were a demonstrable credit quality advantage for a green issuer, this would be reflected in the external rating and thus the issuer would already benefit from a lower capital charge. For banks using the advanced approaches in Basel II, any superior credit quality arising from the greenness of the issuer would be captured in the internal rating system, thus leading to a lower capital charge. One qualifier is that green bonds and green assessment criteria are relatively new, so it will take additional years of loss experience over at least one full business cycle to enable banks to robustly document in their internal models any superior loss experience with green exposures relative to non-green exposures.

The suggestion of a more liberal leverage requirement for green bonds runs contrary to the prudential rationale underpinning its introduction in Basel III. Experience in the global financial crisis revealed that many models had underestimated the key risk parameters of probability of default, loss given default, and the correlation across portfolios. The leverage limit provides a failsafe against the underestimation of losses by introducing a hard limit on the leverage of a bank. The key distinction of the leverage limit as a prudential standard is that it uses total assets, rather than risk-weighted assets. Providing a less stringent treatment for any class of asset is not aligned with the failsafe concept and is highly unlikely to be adopted by the Basel Committee.

Prudential frameworks can and should ensure that financial institutions specifically address climate change and other environmental risks. For banks, these types of risks would be explicitly considered as elements of the internal capital adequacy assessment process under Pillar 2 of Basel II. This would ensure that banks' internal risk assessments result in additional capital being held against exposures with high degrees of climate risk such as fossil fuel electric generation, and recognize the relatively lower capital requirements for 
lesser environmental risks such as renewable energy. The supervisory review process would similarly expressly consider environmental risks.

Central banks establish collateral eligibility criteria to encourage banks to hold highquality liquid assets to mitigate their liquidity risk and to protect the central bank itself and, indirectly, to protect taxpayers from potential losses when lending to meet banks' requirements for liquidity. Accepting green bonds that do not meet the quality criteria, for example those with a below investment grade rating, or using a lower margin requirement (smaller "haircut") for a green bond relative to a similarly rated non-green bond, exposes the central bank to a higher risk of loss. Since such instruments will be more difficult to sell or repo with a private sector counterparty during periods of market distress, it would also increase the probability of banks having to rely on the central bank rather than the market to meet their liquidity requirements. As a practical matter, there are very few bond issues, green or otherwise, in ASEAN+3 that do not have a sufficiently high credit rating to qualify as collateral for central bank liquidity facilities due to investor preference for highly rated issues; thus the impact of favorable treatment would be minimal.

Within ASEAN +3, the potential benefits of purchase of green bonds by central banks is minimal. Institutional investors would hold more bonds, green or otherwise, if available, so increasing demand for green bonds by encouraging central bank purchases contributes little to development of the market. There is also concern that local currency green bonds may not be suitable investments for central bank reserves. Central bank reserves are typically held in high-quality securities denominated in reserve currencies and gold to, among other things, support and maintain confidence in the policies for monetary and exchange rate management, including the capacity to intervene in support of the national currency and limit external vulnerability by maintaining foreign currency liquidity to absorb shocks during times of crisis. ${ }^{123}$

Some green bonds may fall within the parameters of central banks' reserve management investment policies, and indeed, some central banks do hold qualifying green bonds in their reserve portfolios. However, directing reserve managers to purchase green bonds not denominated in reserve currencies or traded in broad and liquid markets would expose central banks to the risk of being unable to quickly liquidate reserve holdings at minimal loss in time of market disruption. This potentially jeopardizes the ability of the central bank to intervene in the markets for stability purposes.

The exemption of green bonds from capital controls would make them more attractive to foreign investors relative to other local currency bonds, but would have little impact on domestic investors. As with encouraging central banks to invest in green bonds, encouraging additional foreign investment would have less practical impact in ASEAN+3 countries than measures to increase the supply of green bonds. A further consideration is the concern of some ASEAN+3 policy makers over the potential volatility of capital flows. While the green bond market is small, dealing with a separate asset class differently than otherwise identical corporate bonds would be an additional complication, both in normal times and in responding to an incident of market disruption.

123 International Monetary Fund. 2013. Revised Guidelines for Foreign Exchange Reserve Management. Washington, DC. 
Measures to develop the green bond market should not be comingled with the prudential framework for banks and other deposit-taking institutions and best practices for reserve management. Measures to develop domestic institutional investors and promote greater awareness and demand for green bonds, and especially measures to increase the supply of green bonds, are likely to have more impact without the potentially destabilizing effects of relaxing international best practices in financial stability. Prudential supervisors can and should ensure that risk-based supervision frameworks explicitly consider climate change and other environmental risks in the risk management and capital allocation process.

\section{F. Market Development Initiatives}

Market development initiatives are indirect measures to promote local currency green bond markets. None are essential for green bond markets to form. Instead, these policy initiatives nudge green bond markets forward by creating a supportive environment.

\section{National Green Bond Development Committee}

A National Green Bond Market Development Committee would facilitate development of local currency green bond markets by identifying obstacles to green bond issuance and recommending policies and initiatives to overcome them. Also, if the committee were composed of senior regulators and market participants, then it could provide the political and economic heft to help ensure that any policies it recommends are implemented in an effective and timely fashion.

The GFC of the China Society for Finance and Banking was established in 2015. The GFC operates under the authority of the PBOC and is chaired by a senior member of the bank. The GFC's scope of activities include (i) studying policies and legal issues related to green financing, (ii) promoting the development of green financial products and services, (iii) encouraging institutional and retail investors to consider the environmental impact of their investments, (iv) highlighting best practices in the industry, (v) ensuring cooperation among government entities and other institutions in promoting green finance, and (vi) participating in global forums to learn about international experiences and to promote the PRC's views on green financing. Membership is by application and invitation, and includes senior representatives from key government ministries, state-owned enterprises, and private sector institutions. Nonmember experts are invited to participate on specialized committees.

A suggested mandate for countries considering a National Green Bond Market Development Committee would include (i) assessing the knowledge of green bonds among domestic investors and issuers; (ii) assessing the capacity of local underwriters and other intermediaries to support the issuance of green bonds; (iii) identifying regulatory and other impediments to the issuance of green bonds; (iv) recommending measures to promote the development of green bond markets, set timetables, and monitor their implementation; and ( $v$ ) providing ongoing advice and feedback to policy makers and market participants on green bond markets. Once initial work is complete, a National Green Bond Market Development Committee could then take on some direct responsibilities to promote local currency green bond markets, such as creating awareness of green bonds (below). 
For maximum effectiveness, the committee should have representatives from six stakeholder groups: policy makers, issuers, investors, underwriters, external reviewers, and civil society organizations (e.g., academics and environmental nongovernment organizations). If there is insufficient expertise in the country on green bonds, then consideration could be given to adding international experts to the committee, whose members would serve on a voluntary basis and commit to a minimum term of 3 years. To be effective, the membership should be limited to senior decision makers from participating organizations who are able to commit resources from their organizations to support priorities identified by the Committee. Further, committee members should be prohibited from sending substitutes to meetings to prevent the authority of the committee from diminishing over time. A small secretariat should be established, which could be located within an existing industry association or at a university. A National Green Bond Development Committee could be established as a subcommittee of a broader National Green Financing Committee (or a similar entity).

\section{National Network of Green Bond Investors and Issuers}

The most important participants in green bond markets are issuers and investors. A forum allowing market participants to share experiences and form a consensus on policy issues would help promote green bond markets. A network would also create peer pressure among members to develop green bond capabilities by exposing participants to leading industry practices and achievements.

A Network of Green Bond Investors and Issuers would be composed of market participants that have issued green bonds or intend to do so. A suggested mandate would be to (i) share experiences and expertise on green bonds, (ii) recommend policy initiatives to promote green bonds, (iii) provide comments and feedback on policy initiatives developed by other parties, and (iv) create awareness of local currency green bond markets. Membership should be limited to professionals with direct responsibility for issuing or investing in green bonds or those responsible for sustainable development (issuers) and ESG analysis (investors). Membership should also include at least one member of the National Green Bond Development Committee. Committee members should serve on a voluntary basis and commit to a minimum term of 3 years.

The network could be established as a standalone entity, an appendage of a National Green Bond Development Committee, or a network established by existing national investment management associations (or similar) or national treasury management associations (or similar). Further, there could be a single network composed of both investors and issuers or separate networks for each.

The Investor Network on Climate Risk (INCR) is composed of about 130 institutional investors located in North America that collectively manage assets of about $\$ 17$ trillion. It is coordinated by the CERES, a nonprofit environmental organization which serves as the secretariat. The INCR operates several working groups, which share information and best practices on climate finance, develop and support policy proposals, and coordinate shareholder proposals and engagement on climate change issues. For instance, the Carbon Asset Risk Working Group works with investors to develop engagement strategies for fossil fuel utilities to lower their carbon emissions. The INCR is one of four regional 
networks that are part of the Global Investor Coalition on Climate Change. The others are the Institutional Investor Group on Climate Change (Europe), Investor Group on Climate Change (Australia and New Zealand), and Asia Investor Group on Climate Change (AIGCC). ${ }^{124}$

The potential catalyst provided by a network would be modest during the embryonic stage of green bond markets due to the low number of investors and issuers of green bonds. Even in the medium-term, however, a Network of Green Bond Investors and Issuers is likely to be less effective in promoting green bonds than a National Green Bond Development Committee because of its narrow mandate. Further, without proper coordination, there is a risk that a network and a National Development Committee could lead to fragmented authority, conflicting priorities, and competition for resources. As green bond markets take hold in ASEAN +3 countries, investors would likely be better served by joining the existing AIGCC and pushing for a regional green bond working group than by creating a national network.

\section{Initiatives to Promote Greater Awareness of Green Bonds}

Initiatives to increase awareness of green bonds include (i) public statements by government officials and regulators on the importance of green bonds to broad national objectives such as sustainable development; (ii) opinion pieces in local media (including sponsored "advertorials"); (iii) publication of regular briefings on local and international green bond market developments; (iv) a dedicated website, or a section of an existing website, with data and related information on local green bond markets and links to relevant international sources (e.g., ICMA, CBI); (v) dedicated workshops and conferences on green bonds; ( $\mathrm{vi}$ ) sessions on green bonds in broader conferences on capital markets; and (vii) awards programs for green bond participants. Other policy options identified in this report serve to increase awareness of green bonds as well. For example, setting up a dedicated regulatory framework for green bond issuance, having public entities issue green bonds, and commitments by public investment funds to allocate a portion of their fixed income portfolio to green bonds also increase awareness of green bonds.

The many activities of the $\mathrm{CBI}$ may be the best-known examples of efforts to increase awareness of green bonds. The $\mathrm{CBI}$ collects data and offers analysis on green bond issues, publishes reports on developments in specific markets (e.g., the PRC) and on components of green bond markets (e.g., securities listings and reporting), organizes conferences and workshops, and issues annual awards to green bond market participants.

The biggest risk to awareness programs is that they do not permeate beyond a small group of green bond advocates. For example, if green bond events are attended by the same people time after time, the effectiveness of awareness programs is limited. A second risk is overstating the benefits of green bonds by not adequately addressing the concerns of issuers and investors who are not yet sold on the merits of green bonds. Constructive engagement is more effective than denying the legitimacy of their concerns.

124 The AIGCC was set up in 2011 and joined the Global Investor Coalition on Climate Change in 2016. The network is small. As of June 2017, the AIGCC had 14 members, three of which were industry associations and another two were service providers. 
Awareness programs may be most effective if coordinated through a National Green Bond Development Committee (or similar).

\section{Green Bond Indices}

Bond indices define the universe of investment opportunities for an asset class and a measure of its performance. Indices are used by investment managers to construct investment products, manage portfolio risk, and assess investment performance. The construction of green bond indices makes it easier for investment managers to offer green bond investment products.

Almost all of the world's investment indices are provided by private firms. In constructing a green bond index, the index provider must first establish green eligibility criteria for green bonds. This is normally done in consultation with a firm with environmental finance expertise. The green eligibility criteria could include all green labeled bonds, expertapproved green labeled bonds (i.e., green labeled bonds that are attested to being green by recognized experts), or labeled green bonds (all or expert-approved) plus unlabeled green bonds identified by experts. Once this is done, index providers must also establish inclusion criteria based on bond characteristics. Bond type, currency, term to maturity, minimum credit rating, and minimum issue size are the key criteria. Inclusion criteria should be developed in consultation with market participants in local currency bond markets. Once an index is operational, data on its construction and performance must be made available on major financial information sources, such as Thompson Reuters and Bloomberg.

A green bond index should be constructed by an established index provider. This adds credibility and lowers cost since there are significant economies of scale in the provision of indices. There are many index providers to choose from, although the industry has undergone considerable consolidation in the past few years. Many bond market indices were developed by investment banks to support their market-making and underwriting businesses, but most have sold their index units to specialized data providers, such as Bloomberg, MSCl, Standard \& Poor's, IHS Markit, and FTSE Russell (part of the LSE Group). While consolidation and rapid advances in computer technology has reduced the cost of producing bond market indices, green indices are generally more expensive to provide because in most cases index firms must work with outside experts on environmental finance to construct the index.

Several green bond indices have been created. Global green bond indices include the S\&P Green Bond Select Index, Solactive Green Bond IG Index, the BofA ML Green Bond Index, and the Barclays MSCl Green Bond Index. Green bond indices for the PRC include the ChinaBond Green Bond Index, the ChinaBond Green Bond Selected Index, and the ChinaBond China Climate-Aligned Bond Index. Details on these indices are provided in Chapter II, section $\mathrm{K}$ of this report.

It is too soon to establish green bond indices in most ASEAN+3 countries due to the small number of local currency green bonds issued (even with the inclusion of unlabeled green bonds). Even a regional green bond index is inadvisable at this stage since it would be dominated by the PRC and green bond indices already exist in the PRC market. 
Another reason for caution in creating green bond indices is that it is not clear that green bonds are a distinct asset class. Most green bonds are issued as general obligation bonds and thus have the same credit characteristics as conventional bonds from the same issuer. Investors in ASEAN+3 do not see green bonds as a distinct asset class. Even in Europe, where awareness of green bonds is highest, the number of dedicated green bond mutual funds and institutional mandates is small-most green bonds are held within broad responsible investment and conventional fixed income portfolios. Finally, the index business is highly competitive and firms are quick to develop indices if they see demand from market participants. Thus, official support for the development green bond indices is not required.

\section{Green Bond Listings on Securities Exchanges}

Green bond listings increase awareness of green bonds among investors by making them easier to identify and by centralizing information on them. They may increase transparency if listing rules include detailed disclosure requirements. Green bond listings may facilitate index construction, though this is only useful to investors if most green bonds are listed. In situations where bond trading largely takes place on exchanges, green bond listings may improve liquidity.

Green bond listings require exchanges to (i) specify listing criteria for green bonds, (ii) provide green bonds with a unique identifier code, and (iii) aggregate data on green bonds in dedicated sections of an exchange's information systems such its website. The green bond listing criteria should be aligned with the GBP, or national standards where they exist, and should place detailed reporting requirements on issuers.

Several securities exchanges have established green bond listings, including the Luxembourg Stock Exchange and London Stock Exchange. The Shanghai Stock Exchange and Shenzhen Stock Exchange have launched green bond pilot projects with the intention of establishing comprehensive green bond listings in the future.

There is a risk of market fragmentation if listing requirements are not closely aligned with the GBP or national standards. The impact of securities exchanges establishing green bond listings on the development of green bond markets is likely to be small since in most countries there are few green bonds to list and the creation of green bond listings will not encourage greater supply. Further, most bonds do not trade on exchanges in ASEAN+ 3 countries so the liquidity benefit of green bond listings is likely to be modest.

\section{G. Regional Initiatives}

The previous sections have identified and assessed the range of policies available to national governments to promote the development of local currency green bond markets. Many of these policies can also be pursued on a regional basis as well. Those that are most relevant from a regional perspective are explored below, although with less detail on the structure and rationale for these polices since these are discussed in earlier sections. 


\section{Regional Green Bond Standards}

Regional standards may encourage cross-border investment in local currency green bonds within ASEAN+3, helping to match surplus savings to large investment needs. Regional standards are consistent with the ASEAN Capital Markets Forum (ACMF) commitment to promote ASEAN asset classes. ${ }^{125}$

The ACMF released in November 2017 agreed ASEAN green bond standards as part of the broader regional convergence program. The standards are principles-based, thus accommodating 10 different legal frameworks and approaches to capital market oversight, and the spectrum of stages in capital market development. The agreed regional standards will have to be implemented by national authorities.

The ASEAN green bond standards are closely aligned with the GBP, which helps to promote alignment with international and other national and regional standards. The ASEAN standards use the same indicative list of eligible projects as the GBP. An indicative list has the benefit of leaving open the possibility to include technologies not contemplated at the time of drafting and avoids making regulatory authorities the arbiter of what is green. One significant difference from the GBP is the explicit exclusion of fossil fuel power plants, which is aligned with the preferences of international green investors.

As with the GBP, external reviews are recommended but not required. The ASEAN standards include text not found in the GBP requiring external review providers to disclose credentials and expertise, which could help to ensure the credibility of external reviews. Issuers' reporting requirements in the ASEAN standard closely parallel the GBP.

Some market participants will be disappointed that the ASEAN standards do not provide more comprehensive guidance on eligible projects. However, countries desiring more specific guidance could supplement the broad categories of green projects with more detailed project catalogues. This would parallel the way the CBI Standard elaborates on, but is consistent with, the GBP.

\section{Credit Guarantees}

Credit enhancement is one way to improve the viability of green projects, making them more attractive to private capital, and can also play a role in facilitating securitization. A regionally focused green credit guarantee scheme could play a catalytic role in promoting the green bond market.

The Credit Guarantee and Investment Facility (CGIF), with a mandate spanning ASEAN+3, can accommodate green projects within its portfolio. CGIF participated in the financing package that included the first green bond from the Philippines, AP Renewables. CGIF might specifically allocate resources to green bonds at a national level and across the region.

125 ACMF. 2016. ACMFAction Plan 2016-2020. http://www.theacmf.org/ACMF/upload/acmfactionplan2016-2020.pdf. 
Given the current availability of credit enhancements through the MDBs, export credit agencies, development banks, and private investors, as well as CGIF, it is not clear that a dedicated green credit enhancement facility would bring significant benefits. Considering organizational requirements and start-up times, it would likely be preferable to build additional green bond capacity onto existing credit guarantee operations rather than create a new dedicated green entity. This could be managed as a separate portfolio, or as part of the overall portfolio, with the former offering the potential to attract investors with a specific green focus.

\section{Awareness Program}

Awareness programs prompt market participants to learn more about green bonds and signal to them that public and private authorities consider them important. In most cases, green bond awareness programs are most effectively pursued at the national level, especially if a National Green Bond Development Committee exists. This allows awareness programs to be tailored to the specific needs of each country and to be linked to specific policy initiatives that countries have adopted to promote green bond markets.

Two exceptions where awareness programs may be better pursued at a reginal level are dissemination of information on green bond markets through the AsianBondsOnline $(A B O)$ website and annual updates to the ASEAN+3 Bond Market Forum (ABMF) by ICMA on global green bond developments and the GBP. ABO provides an excellent template for a regional initiative on green bonds. A regional section on green bonds or a green bond section for each country could be added to the $A B O$ website and green bond issuances could be reported separately in the Asia Bond Monitor. In addition to increasing green bond awareness, this would provide a central repository for information on green bonds in ASEAN+3 countries. A regular briefing by ICMA for ABMF would provide a vehicle for policy makers, regulators, and market participants to keep abreast of international developments in green bonds and the evolution of the GBP.

\section{Regional Technical Assistance Facility}

A regionally focused technical assistance facility could support issuers in bringing green bonds to market. In addition to addressing the binding constraint in developing the green bond market, the lack of supply, it would also contribute to local currency bond market development more generally.

There are considerable benefits to providing advisory services and capacity building on a regional basis. First, the content of training materials and advisory services will have a high degree of commonality from one country to the next. This allows for significant economies of scale in the development of training programs and materials and the delivery of advisory services. It also allows for the creation of a center of excellence on green bonds and a central repository for training materials and other information. Differences in national regulatory standards with respect to the processes for issuing green bonds are likely to be small given the work of the ACMF and reliance on the GBP as the foundation for ASEAN standards. The biggest additional cost of a regional approach is ensuring that the programs meet local language needs. A second benefit of a regional approach to training and advisory 
services is that best practices for green bond issuance will be quickly disseminated across ASEAN +3 countries.

Advisory services involve experienced green bond experts working directly with treasury officials and investment bankers to structure a green bond issue. These activities would be limited to structuring a bond to meet green standards and do not extend to those elements of the bond that are the same as conventional issues. Training could be provided to individual countries on a case-by-case basis. This might include workshops and online and written materials.

An additional component of regional technical assistance could be a grant program to partially offset the higher costs of green bond issuance. It could be modeled on the MAS Green Bond Grant Scheme launched on 1 June 2017. This program reimburses issuers up to $\$ \$ 100,000$ for the cost of obtaining an external review. The green bond must be issued in Singapore, have a minimum size of $S \$ 200$ million, and have a maturity of at least 3 years. The issuer can be from any country and the bond can be denominated in any currency. Reimbursement is limited to actual expenses paid to the external reviewer. Internal administrative costs associated with the green bond issue are ineligible. At present, there is no list of eligible external reviewers, although one may be established in the future if abuses emerge.

\section{Regional Green Bond Network}

A network of green issuers and investors would create greater awareness of green bonds, provide a forum for a common industry position to develop, allow the dissemination of best practices, and create peer pressure to become more engaged in green bond markets. It would likely be more effective for market participants with an interest in green bonds to join the existing AIGCC rather than considering a new regional entity. The AIGCC was established in 2011 by the Association for Sustainable and Responsible Investment in Asia, now PRI Asia, to create awareness among Asia's asset owners and financial institutions about the risks and opportunities associated with climate change and low-carbon investing. It currently has 14 members.

\section{Public Issuance of Green Bonds by Regional Entities}

Regional and international entities, such as the World Bank and ADB, help to promote the development of local currency bond markets by issuing bonds in those currencies. For instance, $A D B$ was the first foreign issuer of local currency bonds in several ASEAN+3 countries and, through its Asian Currency Note Program, has committed the equivalent of $\$ 10$ billion to issuing local currency bonds to support the ABMI. The World Bank and the New Development Bank have both issued green bonds in ASEAN +3 currencies. ADB has issued a green bond in Indian rupees and provided credit guarantees to a Philippine issuer of a green bond, but has not yet issued a green bond in an ASEAN+3 currency.

ASEAN +3 governments can encourage regional and global entities to issue local currency green bonds by supporting their efforts to do so (e.g., backing policies to issue green bonds and committing government-controlled funds to be cornerstone investors) and by proposing and approving environmentally beneficial projects funded by these agencies. 
Bond issues by regional and global entities tend to have high visibility because of their status in the market and because the issues tend to be of large size.

\section{Regional Green Bond Index}

An available green bond index facilitates the ability of investment managers to offer green bond funds and exchange traded funds (ETFs). Creating a regional local currency green bond index would do little to promote the development of green bond markets. In addition to the issues described earlier with respect to national indices, market participants indicated that only a few institutional investors in ASEAN+3 countries have regional local currency bond mandates. When extending their fixed income portfolios beyond their home currency, most institutional investors look to add global or emerging market mandates to their portfolios and mandates linked to regional indices are rare.

\section{Regional Exchange Traded Fund}

A regional local currency green bond ETF would increase awareness of green bonds, signal that there is demand for green bonds to issuers, and facilitate retail investor fund flow into green bonds; however, the necessary preconditions would first have to be met to make such an ETF successful.

An ETF is a marketable security that can be bought or sold on a securities exchange. It tracks the performance of an index by holding a basket of securities in the same proportion as the constituent components of the index it is intended to match. Most (but not all) ETFs are managed on a passive basis and offer low investment management fees. While ETFs are similar to index mutual funds, they differ in two critical ways: (i) ETFs can be bought or sold at any time when a market is open, whereas mutual funds can only be traded at the market close; and (ii) the price at which an ETF is bought or sold may differ from its net asset value, whereas mutual fund transactions are priced using a fund's net asset value.

ETFs are one of the fastest-growing segments of the investment management industry. According to data from ETFGI, at the end of April 2017, there were about 7,000 ETFs (and similar products) available worldwide, provided by 313 providers, and with total assets of about $\$ 4$ trillion. ${ }^{126}$ ETFs are popular in ASEAN+3, though less so than in the US. For the Asia and Pacific region (excluding Japan), there were 1,134 ETFs (and similar products) available from 121 providers listed on 17 exchanges in 14 countries with total assets of $\$ 155$ billion at the end of August 2017. ${ }^{127}$ The ETF sector is highly concentrated.

A regional local currency green bond ETF requires a legal structure, an initial investor, and an index. The legal structure could be a single fund offered in multiple jurisdictions or a series of country-specific feeder funds that hold units of a master fund. The initial investor is normally the fund sponsor (e.g., State Street Global Advisors) but is sometimes an institutional investor. The index would be a basket of local currency green bonds denominated in ASEAN +3 currencies. Normally, the index is created and calculated by a third-party index provider but this is not always the case.

\footnotetext{
R. Wigglesworth. 2017. Global ETF Assets Reach \$4 Trillion. Financial Times. 10 May.

ETFGI. 2017. ETFGI Press Release. 15 September.
} 
There are currently two green bond ETFs offered to investors: the Lyxor Green Bond Undertaking for Collective Investment in Transferable Securities (UCITS) ETF (available in Europe) and the VanEck Vectors Green Bond ETF (available in the US). Both are small, with combined assets of less than $\$ 25$ million as of 30 June 2017. A regional example of an ETF is the Asian Bond Fund Pan-Asia Index Fund (PAIF), which aims to track the performance of the Markit iBoxx Asian Bond Fund Pan-Asia Index. PAIF invests in local currency government and government-related bonds from eight Asian markets: the PRC; Hong Kong, China; Indonesia; the Republic of Korea; Malaysia; the Philippines; Singapore; and Thailand. As of 31 May 2017, PAIF had assets under management of just less than $\$ 4$ billion, although a large portion of this was from central banks and monetary authorities of the Executives Meeting of the East Asia and Pacific Central Banks. ${ }^{128}$

Establishing a local currency green bond ETF would not be feasible in the near-term due to the lack of a pipeline of green bond issues, and a likely inability to purchase existing green bonds in the secondary market due to the predominance of buy-and-hold investors. At present, there is limited demand for green bonds by retail investors in ASEAN+3 countries. Even in North America and Europe where green bond markets are more mature, retail demand for green bond ETFs and mutual funds has been modest. ${ }^{129}$ Also, the ETF sector is mature and highly competitive with about 7,000 ETFs available worldwide. ${ }^{130}$ Firms are quick to launch new ETFs where they see demand.

\section{H. Summary and Conclusion}

The broader objective of government policies and direct interventions is to attract incremental financing for green projects. Interventions that simply promote green bonds over other financing sources are less desirable than measures that increase overall investment in projects and assets that will have a positive effect on climate change and sustainable development.

Throughout ASEAN+3 the current binding constraint is not a lack of financing, but a shortage of investable projects. Thus, measures to increase supply by bringing new projects to market, particularly when linked with broader national strategies to deal with climate change, will have greater impact than measures targeted at increasing demand for green bonds.

The preconditions for local currency bond markets and private financing of green projects and assets must be put in place prior to considering direct interventions in support of green bonds. This requires the following:

(i) continuing efforts to develop local currency bond markets;

(ii) continuing efforts to address the main bottleneck in attracting private investment to green financing opportunities, bringing investable projects to market;

128 PAIF does not disclose the amount held by central banks and monetary authorities. Market participants have suggested that it is well over half the fund.

129 Total assets under management in green bond mutual funds and ETFs is less than $\$ 1$ billion in a global market of $\$ 40$ trillion invested in regulated open-ended funds. Investment Company Institute. 2017. Investment Company Fact Book. Washington, DC.

130 ETFGI. 2017. ETFGI Press Release. 13 September. 
(iii) considering creation of a national inventory of green projects; and

(iv) considering measures to enhance the financial viability of green projects.

When the preconditions are established, suggested national policy priorities for ASEAN+3 governments include the following:

(i) establishing a policy framework for green bonds by

(a) linking efforts to promote green bond markets into national strategies dealing with climate change and/or sustainable development, and

(b) adopting principles-based green bond regulatory frameworks for green bonds with an inclusive definition;

(ii) expanding the supply of and demand for green bonds by

(a) encouraging public entities to issue green bonds,

(b) encouraging public funds to invest in local currency green bonds,

(c) requiring issuers to report on ESG activities and measures,

(d) requiring institutional investors to report on ESG risk exposures and how they are being managed,

(e) requiring knowledge of ESG analysis to be a licensing requirement for investment managers,

(f) ensuring prudential frameworks for financial institutions to explicitly address climate change and other environmental risks,

(g) considering additional capital investment in existing credit enhancement vehicles to provide capacity to develop dedicated green portfolios,

(h) considering the potential benefits and costs of tax incentives for green projects in the context of national priorities and fiscal regimes, and

(i) supporting capacity building efforts in a targeted fashion;

(iii) promoting general market development by

(a) establishing a National Green Bond Development Committee (or similar),

(b) providing support for awareness programs coordinated through a National Green Bond Development Committee (or similar),

(c) supporting efforts by others to develop climate-aligned bond indices that include both labeled and unlabeled green bonds, and

(d) supporting efforts to establish a National Network of Green Bond Investors and Issuers (without mandating membership or providing financial support); and

(iv) promoting regional policy priorities such as

(a) developing a regional technical assistance facility for green bond issuance,

(b) providing specific coverage of green bonds on AsianBonds Online,

(c) considering requesting ICMA to present annual updates on the GBP and green bond market development globally to members of $A B M F$,

(d) considering encouraging CGIF to allocate a portion of guarantee operations to green bonds,

(e) continuing efforts to work with market participants in addressing barriers to cross-border bond issuance and investment under ABMF,

(f) encouraging regional and global public entities to issue local currency green bonds, and

(g) encouraging regional and global public funds to commit to investing in local currency green bonds. 
There are additional policy options available that have at least some merit, but further consideration of them should be set aside for now as alternatives are likely to provide greater impact relative to the costs involved. Policies that should not be considered at this time include the following:

(i) tax incentives or subsidies for issuers of green bonds,

(ii) official support for post-issuance classification of unlabeled green bonds,

(iii) tax incentives for investors,

(iv) official assistance or financial support for a regional green bond index,

(v) official assistance or financial support for a regional local currency bond ETF,

(vi) official support for a regional securitization vehicle, and

(vii) official support for a regional network on green bonds.

There are also policy options that have high risks in terms of potential fiscal, market, and financial stability impacts, and thus should not be further considered. These include proposals to weaken prudential standards or diverge from best practices in central bank reserve management, as the potential negative financial stability implications outweigh potential benefits.

The generally lower priority assigned to demand-oriented policies may seem counterintuitive given the generally low levels of knowledge and interest in green bonds among institutional investors in ASEAN+3 countries. It might seem that addressing these shortcomings would be important since supply seldom creates its own demand. However, the situation in ASEAN+3 countries presents an unusual situation.

Institutional investors in ASEAN+3 countries have strong demand for fixed income securities, especially high-quality, higher-yielding corporate bonds. Because green bonds are similar in structure, term, and yield to conventional bonds, market participants indicated that green bonds would be easily placed with institutional investors. Green bonds are not popular with issuers because of the extra cost of issuance, not because of a perceived lack of demand.

Proper sequencing of policies is also critical to the development of local currency green bond markets. A well-functioning local currency bond market is an essential precondition and, given that many green investments are best structured as project bonds, a local currency infrastructure bond market is also beneficial. Given the absence of institutional investors with responsible investment mandates to guide issuers and underwriters in the structuring of green bonds, a comprehensive policy framework for green bonds is also needed to support the development of local currency green bond markets. Only after these are in place, should governments pursue other polices to promote green bond markets. Priority should be given to supply-oriented policies for the reasons noted above. Some demand-oriented policies and market development initiatives could also help, but their potential impact is more modest and will take longer to have an effect. Regional initiatives promoting cross-border investments in green bonds and those promoting increased supply should be given priority. 


\section{Appendix 1: Country Background Notes}

\section{A. Brunei Darussalam}

runei Darussalam's bank-dominated financial sector is relatively large as a share of gross domestic product (GDP), but reflecting the small size of the country-population of about 425,000-is small in absolute terms.

The financial system includes both Islamic and conventional institutions with total assets of the key financial institutions at end 2016 of $\mathrm{B} \$ 21.1$ billion. There are seven conventional commercial banks and one Islamic bank serving the domestic market. There is also an Islamic Trust Fund which provides specialized Islamic financial services. State Street (Brunei) Sdn. Bhd. operates with a restricted banking license.

The insurance sector in Brunei Darussalam is small for a high-income country, with total conventional insurance and takaful (Sharia-compliant insurance) assets equivalent to less than $10 \%$ of GDP. This is in part due to the extensive social insurance system, which reduces incentives for individual saving. The Employee Trust Fund-the state-run provident fund-is one of the largest financial institutions, although it releases no data with respect to its investment holdings and performance. The Brunei Investment Agency, the sovereign wealth fund, has estimated total assets of about $\$ 39$ billion, making it larger than the rest of the financial system combined, but it too releases no information on its investment holdings and performance. ${ }^{1}$

The Autoriti Monetari Brunei Darussalam is a unified supervisory authority with responsibility for banking, insurance and capital markets. The regulatory framework for capital markets activities derives from the Securities Order, 2001 (as amended in 2001, 2003, and 2005) and the Mutual Funds Order, 2001. The government has issued a modest amount of short-term sukuk al-ijarah. There are no public corporate bond issues, although a few Bruneian corporates have issued sukuk in the form of private placements. There is no regulatory regime aside from the Companies Law, and no supporting infrastructure such as securities clearing and settlement systems or a central depository. No green bonds have been issued by Brunei Darussalam-domiciled entities, and a regulatory framework for green bonds has not been put in place. 
Table A1.1: Brunei Darussalam Financial and Capital Market Overview, 2016

\begin{tabular}{l|c|c|c|c} 
& Number & $\begin{array}{c}\text { Assets } \\
\text { (B\$ million) }\end{array}$ & $\begin{array}{c}\text { Assets } \\
(\$ \text { million) }\end{array}$ & $\begin{array}{c}\text { Assets } \\
\text { (\% of GDP) }\end{array}$ \\
\hline Banks & 8 & 17,918 & 12,391 & 113.8 \\
\hline Insurance and takaful & 12 & 1,483 & 1,025 & 9.4 \\
\hline Finance companies & & 2,096 & 1,449 & 13.3 \\
\hline Collective investment schemes & 13 & 156 & 107 & 0.1 \\
\hline Capital market intermediaries & 11 & 16 & 11 & 0.1 \\
\hline Government securities outstanding & & 473 & 327 & 3.0 \\
\hline
\end{tabular}

Notes: $\$ 1$ = B $\$ 1.45, \mathrm{GDP}=\mathrm{B} \$ 15,747.7$ million.

Sources: Department of Economic Planning and Development, Autoriti Monetari Brunei Darussalam, Brunei Darussalam Financial Sector Blueprint (2016-2025).

\section{B. Cambodia}

Cambodia has a bank-dominated financial system that has been growing rapidly in both nominal terms and relative to GDP. The number of banks has more than doubled over the last 10 years, with seven new banks licensed in the last 2 years alone. Many are very small, with the smallest 25 collectively accounting for less than $10 \%$ of the market and the largest five controlling about three-quarters of the market. Microfinance institutions play an important outreach role as the banks largely focus on urban areas. Microfinance institutions almost doubled in real terms over the last 3 years with assets equivalent to close to one-fifth of GDP at the end of 2016.

Until 2012, there were no life insurance companies in Cambodia. Two foreign-owned and one partially government-owned life insurers have since entered the market in addition to

\section{Table A1.2: Cambodia Financial and Capital Markets Overview, 2016}

\begin{tabular}{l|c|c|c|c} 
& Number & $\begin{array}{c}\text { Assets } \\
\text { (KR billion) }\end{array}$ & $\begin{array}{c}\text { Assets } \\
\text { (\$ billion) }\end{array}$ & $\begin{array}{c}\text { Assets } \\
\text { (\% of GDP) }\end{array}$ \\
\hline Banks & 51 & 96,216 & 23.8 & 118.4 \\
\hline Commercial banks & 36 & 94,439 & 23.3 & 116.2 \\
\hline Specialized banks & 15 & 1,776 & 0.4 & 2.2 \\
\hline $\begin{array}{l}\text { Microfinance institutions } \\
\begin{array}{l}\text { Microfinance deposit-taking } \\
\text { institutions }\end{array}\end{array}$ & 69 & 15,553 & 3.8 & 19.1 \\
\hline $\begin{array}{l}\text { Microfinance institutions } \\
\text { Insurance (total gross premiums) }\end{array}$ & 7 & 13,314 & 3.3 & 16.4 \\
\hline $\begin{array}{l}\text { Listed companies, market } \\
\text { capitalization }\end{array}$ & 12 & 2,239 & 0.5 & 2.8 \\
\hline
\end{tabular}

Notes: $\$ 1$ = KR4,037; GDP = KR81,242 billion.

Sources: National Bank of Cambodia, Cambodia Securities Exchange, Insurance Business Asia (8 February 2017). 
nine general insurers. All of the insurance companies are small. The National Social Security Fund was established in 2007, but it has yet to develop into a significant institutional investor. There are four listed companies, all very small, and no government or corporate debt markets.

The Securities and Exchange Commission of Cambodia is the capital markets regulator with licensing, surveillance, enforcement, and regulation-making authority. The National Bank of Cambodia is responsible for bank supervision and the Ministry of Economics and Finance is responsible for insurance supervision. As part of its program for financial sector development, Cambodia has put in place many of the basic legal requirements, but considerable further work is required for the financial and capital markets to fully develop and bond markets to emerge. No green bonds have been issued by Cambodian entities and a regulatory framework for green bonds has not been put in place.

\section{People's Republic of China}

Financial institutions and capital markets in the PRC have continued to grow rapidly to support economic growth (Table A3). The banking sector, with total assets equal to more than three times gross domestic product (GDP), is now one of the largest in the world. Capital markets, starting from a much lower base than the banking sector, have stock market capitalization and total local currency bonds outstanding each equivalent to about two-thirds of GDP.

While most savings continue to flow into the banking sector, ongoing reforms have supported growth in contractual savings. Insurance company assets now exceed $20 \%$ of GDP, reflecting real growth of more than $40 \%$ over the last 4 years. There are more than 4,000 social insurance funds administered by governments and state-owned enterprises, which traditionally have invested in bank accounts. Management of some of the larger funds is being passed to the National Social Security Fund, which has adopted investment policies more suitable for the long-term obligations of these social insurance funds. Enterprise annuities have grown modestly since inception. Mutual funds have grown fourfold over the last 3 years and are now equivalent to more than $12 \%$ of GDP.

The main prudential regulatory authorities are the China Banking Regulatory Commission (CBRC) with respect to all types of banks, cooperatives, financial asset management companies, and other financial institutions including finance, trust, and leasing companies; and the China Insurance Regulatory Commission with respect to all classes of insurance. The China Securities Regulatory Commission (CSRC) oversees all capital markets activities including investment funds, securities firms, and exchanges. The Ministry of Human Resources and Social Security has oversight responsibility for the National Social Security Fund and enterprise annuities, a form of private pension plan.

\section{Local Currency Bond Markets}

The bond market is segmented with different authorities responsible for its various aspects. The People's Bank of China (PBOC) oversees the interbank bond market, while new issuance in the interbank market is reviewed by NAFMII, a semiautonomous self-regulatory organization (SRO). Enterprise bonds may be issued by state-owned enterprises subject 


\section{Table A1.3: The People's Republic of China Financial and Capital Markets Overview, 2016}

\begin{tabular}{|c|c|c|c|c|}
\hline & Number & $\begin{array}{c}\text { Assets } \\
\text { (CNY billion) }\end{array}$ & $\begin{array}{l}\text { Assets } \\
\text { (\$ billion) }\end{array}$ & $\begin{array}{l}\text { Assets } \\
(\% \text { of GDP) }\end{array}$ \\
\hline Banks & 1,088 & 232,300 & 33,424 & 312.2 \\
\hline Insurance companies & 194 & 15,117 & 2,175 & 20.3 \\
\hline \multicolumn{5}{|l|}{ Pension and social insurance funds } \\
\hline National Social Security Fund & 1 & 2,040 & 294 & 2.7 \\
\hline Enterprise annuities & & 980 & 141 & 1.3 \\
\hline Mutual funds & 3,564 & 9,160 & 1,317 & 12.4 \\
\hline $\begin{array}{l}\text { Stock Market: listed companies } \\
\text { (market capitalization) }\end{array}$ & 3,052 & 50,879 & 7,320 & 68.4 \\
\hline $\begin{array}{l}\text { Government debt securities } \\
\text { outstanding }\end{array}$ & & 34,825 & 5,010 & 46.8 \\
\hline Of which, local currency & & 34,545 & 4,970 & 46.4 \\
\hline foreign currency & & 280 & 40 & 0.4 \\
\hline $\begin{array}{l}\text { Corporate debt securities } \\
\text { outstanding }\end{array}$ & & 18,285 & 2,631 & 24.6 \\
\hline Of which, local currency & & 14,964 & 2,153 & 20.1 \\
\hline foreign currency & & 3,320 & 477 & 4.5 \\
\hline
\end{tabular}

Notes: Data as of the end of 2016 except number of banks and number of insurance companies. Banks at the end of 2015 comprised 3 policy banks, 5 large commercial banks, 12 joint stock commercial banks, 133 city commercial banks, 5 private banks, 859 rural commercial banks, and 71 rural cooperative banks.

$\$ 1=$ CNY6.95 (end of 2016), $\$ 1$ = CNY6.49 (end of 2015); GDP = CNY72,608 billion (end of 2015), GDP = CNY74,412 billion (end of 2016).

Sources: Asset Management Association of China, CEIC Data, China Daily, China Banking Regulatory Commission, Economist Intelligence Unit, AsianBondsOnline, a Hong Kong, China English-language newspaper of record, and Willis Towers Watson Global Pension Assets Study 2017.

to case-by-case approval by the National Development and Reform Committee, whose mandate is to ensure compliance with and implementation of national economic development goals. Exchange-listed corporate bonds are regulated by the CSRC.

By far the largest segment of the local currency bond market in the PRC is the interbank market; it is dominated by the large banks although it also includes a wide variety of other participants. The exchange-listed bond market serves listed companies using the facilities of the Shanghai and Shenzhen exchanges. These issuers tend to be smaller than those in the interbank market and the volume of trading is small relative to the interbank market. Most issuers who list on the exchanges can and do have their securities traded in the interbank market. The bank counter or over-the-counter market, in effect a subsector of the interbank market, serves retail investors.

\section{Green Bonds}

Plans for a green bond market had been announced in 2013 as part of the implementation of the objectives of the 12th Five-Year Plan to transition to a low-carbon green economy. 


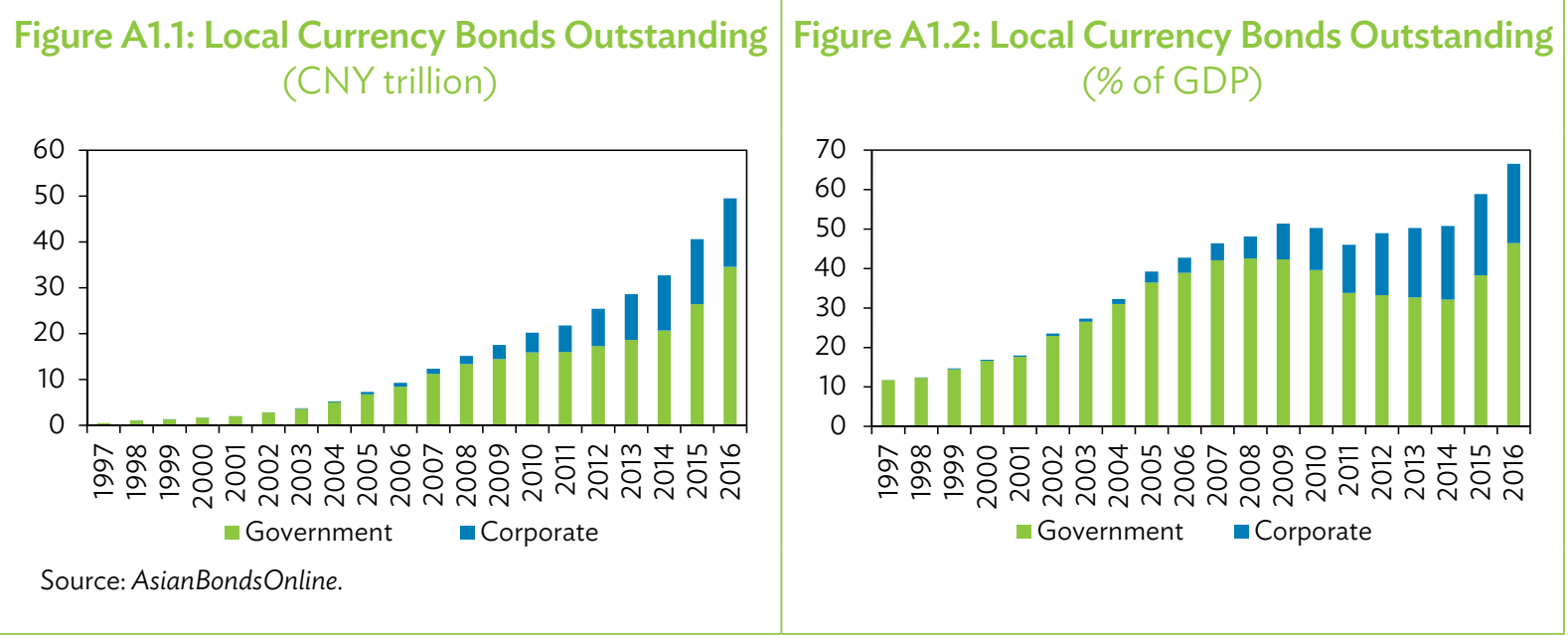

The CBRC began to systematically collect green financing data with the 2013 issuance of the Green Credit Reporting Instructions, which followed its 2012 Green Credit Guidelines. A green finance task force was established in 2014, publishing Establishing China's Green Financial System in April 2015. This led to the establishment of the Green Finance Committee, led by the PBOC with participation of senior officials from regulatory authorities, the financial sector, and academia.

The PBOC published its green bond guidelines for the interbank market in December 2015 (Green Finance Bond Announcement No. 39), followed immediately by the GFC's China Green Bond Endorsed Project Catalogue. Also in 2015, the NDRC published Guidelines for the Issuance of Green Bonds, applicable to the state-owned enterprises subject to its oversight. These were followed in 2016 by guidelines for companies listed on the Shanghai and Shenzhen stock exchanges and the CBRC's Guidance on the Development of Green Bonds Announcement No. 6. In March 2017, NAFMII issued the Non-financial Enterprises Green Debt Financing Instruments Guideline, applicable to nonfinancial issuers in the interbank market.

The guidance issued by all the authorities in the PRC, with the exception of the NDRC, is generally similar and broadly in line with the 2016 version of the GBP. The NDRC guidelines provide for 12 project categories, which are generally consistent with the GBP with the exception of inclusion of mitigation of emissions from fossil fuels, use of nuclear energy, and large-scale hydroelectric power. The other major divergence of the NDRC guidelines from the GBP is the requirement that $50 \%$, rather than more than $95 \%$, of the proceeds must be used for green projects.

Guidance by the other authorities in the PRC relies on the GFC's Green Bond Catalogue, which includes six broad categories and 31 subcategories. These are generally consistent with GBP with the exception of the inclusion of mitigation of emissions from fossil fuel production and consumption, and the lack of emission-intensity thresholds for public transport using fossil fuels. Unlike the NDRC, other authorities in the PRC require the full amount of the proceeds to be used for green projects, which is in line with the GBP. 
A second opinion is not required by the NDRC guideline, with the NDRC itself determining the greenness of the issue. While the wording of the other guidance in the PRC encourages second opinions, in practice this has been interpreted by regulators and market participants as requiring a second opinion.

The green bond market in the PRC originated in October 2015 with a $\$ 1$ billion issue by the Agricultural Bank of China, including one renminbi and two US dollar tranches, listed on the London Stock Exchange. This issue predated the PRC national green bond standards, but in line with London Stock Exchange listing requirements for green bonds, it had a second opinion (provided by Deloitte).

The green bond market developed rapidly in the PRC in 2016 as leading market participants responded to government policy direction and the recommendations of the GFC. All bond issuance in the PRC is subject to regulatory review. As part of the effort to promote green bonds, faster approval was offered for green bonds relative to conventional issues, encouraging issuers who could meet the use-of-proceeds requirements to consider green bonds.

Local currency corporate bond issues totaled about CNY6.2 trillion in 2016, of which about CNY240 billion, or about 4\%, were green bonds. ${ }^{2}$ The total PRC bond market stood at CNY52 trillion at the end of 2016, of which 50 trillion was CNY-denominated (Figure A1). Green bonds comprise about $0.5 \%$ of outstanding bonds in the PRC market.

Through the end of June 2017, the PRC green bond market comprised 36 individual issuers and a total of 85 tranches. ${ }^{3}$ Financial issuers, including policy banks and commercial banks, accounted for $84 \%$ of total issuance, with commercial issuers and state-owned enterprises comprising $12 \%$ and $4 \%$, respectively. Twenty-six tranches, or $30 \%$ of the total, did not have second opinions issued with NDRC authorization. Second opinions were largely provided by domestic firms and the local offices of global accountancy firms, with EY providing the certification for half of the 59 tranches with second opinions. Domestic providers of second opinions include accounting firms, ratings agencies, and environmental consulting firms. DNV GL and the accounting firms, which although using local resources have international quality control standards, are the only international providers of second options active in the PRC.

Green bond issuance in the PRC slowed significantly in the first half of 2017, comprising 16 issues totaling $\$ 6.2$ billion, versus more than $\$ 36$ billion in $2016 .{ }^{4}$ In part this reflects broader bond market conditions, with market participants observing that higher rates discouraged bond issuance generally. Yields on AAA (local) corporate issues rose from about $4.0 \%$ at the end of 2016 to $4.5 \%$ at the end of June 2017, and 125 bps since the middle of $2016 .{ }^{5}$ Corporate bonds outstanding in the first quarter of 2017 were virtually flat

AsianBondsOnline. https://asianbondsonline.adb.org/china/data/bondmarket.php?code=Issuance_Volume_USD (accessed 16 August 2017).

Authors' calculations from Climate Bonds Initiative (CBI). Labelled green bonds data. https://www.climatebonds.net/ cbi/pub/data/bonds (accessed 7 July 2017).

$4 \quad$ Climate Bonds Initiative. Labelled green bonds data. https:/www.climatebonds.net/cbi/pub/data/bonds (accessed 7 July 2017)

5 International Monetary Fund. 2017. People's Republic of China Article IV Consultation. Washington, DC. 
relative to a year earlier, a marked change from the average double-digit growth in the PRC local currency bond markets over the last decade. ${ }^{6}$

Most PRC green bonds have been local currency issues. Foreign institutional investors are not active participants in the CNY market, and there are no dedicated SRI or green mandates among domestic institutional investors. Issuers and underwriters confirmed that green issuance had no impact on the investor base as domestic institutional investors have unmet demand for bonds, whether green or conventional, and thus are ready to purchase all quality bond issues coming to market.

Market participants also observed that having completed initial green bond issuance, and thus demonstrated their commitment to the green bond market, issuers were less interested in subsequent green issues. Most commented that there was no pricing advantage for green bonds. Some issuers and underwriters noted that investors had been persuaded to accept slightly lower yields for inaugural green issues as part of a concerted effort to promote the market, but that this was not sustainable.

Market participants had mixed views on the incentive of faster approval for green bond issuance. While some indicated that approval was in fact faster, others indicated that the processing time was similar to that for conventional issues. There may have been faster processing initially, with the review time converging toward that for other bonds as the number of green issues increased. As a result, while the potential for faster approval was an incentive for many inaugural green issues, it is less effective in second and subsequent issues given issuers' mixed experiences with green bond processing times.

Market participants almost unanimously view further government policy actions as necessary to sustain the PRC green bond market. In the medium- to long-term, demand through the establishment of green, sustainable or responsible mandates for institutional investors is required. Given the prevalent focus on yield to the exclusion of other factors, most market participants suggested that some form of tax incentive was required to provide green bonds with a yield advantage.

\section{Hong Kong, China}

The Financial Services Development Council, a high-level advisory body to the Government of the Hong Kong Special Administrative Region of the PRC, established in 2013 an advisory committee on green financing consisting of senior private sector representatives. This led to the 2015 publication of Hong Kong as a Regional Green Finance Hub, which made four near-term and four medium-term recommendations to government.

The near-term recommendations include the following:

(i) pursuing strategic green bond issuance, including government benchmark green issues;

(ii) establishing specific coordination responsibilities for green finance; 
(iii) supporting the growth of a green institutional investor base through awareness programs, training, and tax changes; and

(iv) developing and implementing green fund labeling and green project accreditation schemes.

The medium-term recommendations include the following:

(i) public listings for green sector companies,

(ii) support for private equity,

(iii) encouraging asset owners and managers to consider potential climate and environmental risks to their portfolios, and

(iv) providing supporting services for emissions trading.

Through the middle of 2017, there had been limited uptake on the recommendations, although there have been a number of market-led developments in green financing both before and after the Financial Services Development Council report.

The Hang Seng Corporate Sustainability Index Series, launched in 2010, focuses exclusively on Hong Kong, China and stocks in the PRC selected on the basis of their ESG performance. Hong Kong, China had long been home to the ASrIA and AIGCC, an initiative set up and run by ASrIA. In 2015, ASrIA joined forces with the UNPRI, with Hong Kong, China becoming the Asian headquarters. Hong Kong Exchanges and Clearing Limited strengthened its ESG Guide in the listing rules in early 2016. Listed companies are required to report in their annual or separate ESG reports, on a comply-or-explain basis, general disclosures and a series of defined key performance indicators in the environmental category.

Hong Kong, China-based entities had issued two green bonds through the middle of 2017. In addition, the first green bond by a nonfinancial corporate was issued in Hong Kong, China by the PRC-based wind energy firm Xinjiang Goldwind Science \& Technology. The $\$ 300$ million, 3-year bond was issued in June 2015.

In June 2016, Link Real Estate Investment Trust, one of the largest retail-focused Real Estate Investment Trusts in the world, issued a $\$ 500$ million 10 -year bond, with proceeds dedicated to the following:

(i) new buildings or renovations to existing buildings that have received, or expect to receive, certification according to third-party verified green building standards such as Leadership in Energy and Environmental Design's BEAM Plus;

(ii) projects that result in achieving, based on third-party assessment, at least a 15\% improvement in energy efficiency; and

(iii) projects that reduce waste to landfill, improve water efficiency, or promote adoption of low carbon transportation including electric vehicles and improve climate change resilience.

A second opinion was provided by Sustainalytics.

MTR Corporation, the majority-government-owned publicly listed operator of the Hong Kong Mass Transit Railway, related businesses, and rail systems in other countries, issued 
a $\$ 600$ million green bond in November 2016 as a tranche of its $\$ 4.0$ billion debt issuance program. Proceeds were dedicated to financing low-carbon transportation and other qualifying projects, with a second opinion provided by Sustainalytics. One motivation for the green bond issue by the government-controlled entity was to play a supporting role in developing Hong Kong, China as a green financing center. The issue was sold to a diverse group of Asian, European, and North American investors, reportedly attracting new investors to MTR Corporation debt. ${ }^{7}$

\section{Indonesia}

The Indonesian financial system is bank-dominated, although capital markets have grown steadily since the 1980s to now comprise more than 500 listed companies with market capitalization equal to about 45\% of GDP. Mutual funds, insurance companies, and pensions collectively remain small relative to GDP, with the small size of these institutional investors limiting the growth of local currency bond markets.

The Indonesian Financial Services Authority (OJK) is a unified regulatory agency responsible for oversight of banks, nonbanks, capital markets, and insurance. Many of the regulations of its predecessor agency, the Indonesian Capital Markets and Financial Institutions Supervisory Authority (BAPEPAM-LK), remain in force including the BAPEPAM Rulebook, which is applicable to issuers and other market participants. The issuance of corporate bonds, notes, or sukuk may be done via public offering, which is subject to OJK oversight, or by largely unregulated private placement with less than 50 sophisticated investors. OJK approves the public issuance of corporate debt securities and supervises market participants and intermediaries. The Indonesia Stock Exchange has rulemaking and enforcement powers for listed bonds, but in practice most trading takes place in the over-the-counter market.

\section{Local Currency Bond Markets}

Many previously existing obstacles to bond market development have been addressed and all of the necessary supporting infrastructure is in place in Indonesia. The OJK has an ongoing workplan to promote the market including a study on how to streamline the approval process for bond issuance. ${ }^{8}$ Favorable corporate tax rates have been used to encourage public listings.

The Indonesian local currency bond market has grown steadily in nominal terms, but relative to GDP it remains well below the peak in 2000, which was driven by government financing needs subsequent to the 1997-1998 Asian financial crisis (Figures A3 and A4). Corporate debt securities outstanding have remained relatively constant between $2.0 \%$ and 2.5\% of GDP, with bank financing remaining dominant for most Indonesian corporates. Sukuk comprise a growing segment of the Indonesia bond market. Sharia-compliant instruments are issued and traded in the same manner as conventional bonds and are

MTR Corporation. 2016. MTR Corporation Press Release. 24 October. https:/www.mtr.com.hk/archive/corporate/en/ press_release/PR-16-096-E.pdf.

8 ADB. 2017. ASEAN+3 Bond Market Guide 2017: Indonesia. Manila. 
Table A1.4: Indonesia Financial and Capital Markets Overview, 2016

\begin{tabular}{|l|r|r|r|r} 
& & Assets & Assets & Assets \\
\cline { 3 - 5 } & Number & (Rp trillion) & (\$ billion) & (\% of GDP) \\
\hline Commercial banks & 116 & 6,729 & 501 & 54.2 \\
\hline Rural banks & 1,633 & 114 & 8 & 0.9 \\
\hline Nonbank financial institutions & & 2,201 & 163 & 17.7 \\
\hline Insurance & & 685 & 50 & 5.5 \\
\hline Life insurance & & 395 & 29 & 3.2 \\
\hline Social insurance & & 289 & 21 & 2.3 \\
\hline Employer Pension Fund & 224 & 173 & 13 & 1.4 \\
\hline Financial Institution Pension Fund & 25 & 63 & 5 & 0.5 \\
\hline BPJS Ketenagakerjaan & 1 & 13 & 1 & 0.1 \\
\hline Taspen & 1 & 198 & 15 & 1.6 \\
\hline Mutual funds & & 320 & 24 & 2.6 \\
\hline Listed companies (market capitalization) & 537 & 5,753 & 428 & 46.4 \\
\hline Total debt securities outstanding & & 3,366 & 251 & 27.1 \\
\hline Of which, local currency & & 2,190 & 163 & 17.7 \\
\hline foreign currency & & 1,176 & 88 & 9.5 \\
\hline Government debt securities outstanding & & 2,667 & 198 & 21.5 \\
\hline Of which, local currency & & 1,878 & 139 & 15.1 \\
\hline foreign currency & & 788 & 58 & 6.4 \\
\hline Of which, local currency & & 699 & 52 & 5.6 \\
\hline foreign currency & & 311 & 23 & 2.5 \\
\hline & & 387 & 29 & 3.1 \\
\hline
\end{tabular}

Notes: Data as of the end of 2016 except mutual fund assets under management (as of the end of September 2016). $\$ 1$ = Rp13,436; GDP = Rp12,406 trillion.

Sources: AsianBondsOnline, Bank Indonesia, Otoritas Jasa Keuangan, Indonesia Stock Exchange, Indonesia Pension Conference (April 2017), BPJS Ketenagakerjaan, Ascend Capital Market Intelligence (October 2016).

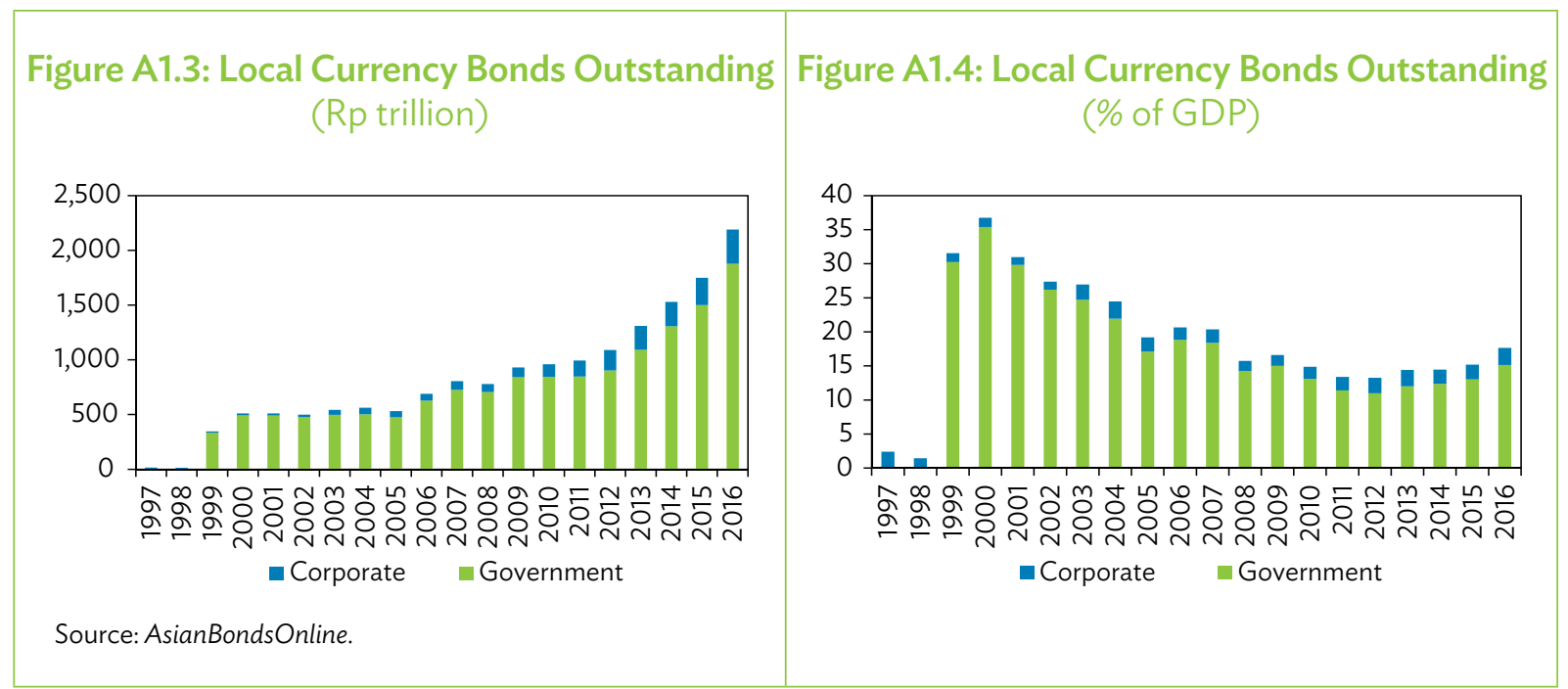


transacted, cleared, settled, held, and reported using the same market infrastructure. Sukuk account for about $5 \%$ of outstanding corporate securities.

There have been no Indonesian green bond issues to date. Green bonds and sukuk could be accommodated by the current regulatory regime. While there is no regulatory definition of green bonds or requirements for a green bond framework, there are no specific obstacles to OJK approval of self-labeled green bonds or sukuk using the existing application process.

\section{E. Japan}

Financial markets in Japan are large and sophisticated, including three globally systemically important banks, and the domestically focused Japan Post Bank which alone has total assets equal to about 39\% of GDP. Life insurance, pension funds, and investment funds are all well established, providing a broad range of contractual savings and funds management products. Stock market capitalization exceeds 100\% of GDP. The Japan Government Bond (JGB) market is the largest in the world relative to GDP and the second largest in absolute terms after the United States Treasury market.

There are multiple shared oversight responsibilities for Japan's financial and capital markets. The Financial Services Agency (FSA) is the main prudential supervisory authority with responsibility for banks and insurance companies and oversight of securities firms. The Bank of Japan also conducts on-site examinations and off-site monitoring with regard to its counterparties which include the banks and other major financial institutions. The Ministry of Health, Labour and Welfare is responsible for pension fund oversight. The Ministry of Internal Affairs and Communications has an oversight role with respect to Japan Postbank and Japan Postbank Insurance.

The FSA shares responsibility for oversight of some of the cooperative institutions including Norinchukin Bank and shinkin banks, while other cooperatives are solely supervised by other government entities. The insurance law excludes the insurance activities of cooperatives from FSA oversight, so these are overseen by the respective ministries.

Life Insurance Association of Japan, General Insurance Association of Japan, Japan Securities Dealers Association, Japanese Bankers Association, Norinchukin Bank, Shinkin Central Bank, IMF Country Report No. 17/244 (July 2017).

The FSA delegates significant responsibility for capital markets oversight to the Local Finance Bureaus of the MOF and several SROs. The Local Finance Bureaus are responsible for review of prospectus and periodic information of issuers, registration of securities firms, and the monitoring and inspection of securities firms with capital of less than $¥ 12$ billion. The SROs include the stock exchanges with respect to listing and market conduct rules and oversight of member firms; the Japan Securities Dealers Association with respect to rule-making and oversight of securities dealer; the Investment Trust Association of Japan, which has rule-making and oversight responsibility for investment trusts (similar to mutual funds); and the Japan Securities Investment Advisers Association, which has similar powers over advisors. 
Table A1.5: Japan Financial and Capital Markets Overview, 2016

\begin{tabular}{|c|c|c|c|c|}
\hline & Number & $\begin{array}{l}\text { Assets } \\
\text { ( } ¥ \text { trillion) }\end{array}$ & $\begin{array}{l}\text { Assets } \\
\text { (\$ billion) }\end{array}$ & $\begin{array}{l}\text { Assets } \\
(\% \text { of GDP) }\end{array}$ \\
\hline Banks & 102 & $1,088,914$ & 10,008 & 202.7 \\
\hline Japan Post Bank & 1 & 209,568 & 1,926 & 39.0 \\
\hline Government Pension Investment Fund & 1 & 144,903 & 1,332 & 27.0 \\
\hline Japan Finance Corporation & 1 & 21,970 & 202 & 4.1 \\
\hline Insurance companies & 94 & 487,400 & 4,480 & 90.7 \\
\hline Life insurance & 41 & 375,505 & 3,451 & 69.9 \\
\hline General and reinsurance & 52 & 31,558 & 290 & 5.9 \\
\hline Norinchukin Bank (no. of subsidiaries) & 12 & 107,062 & 984 & 19.9 \\
\hline Shinkin Central Bank (no. of member banks) & 264 & 37,464 & 344 & 7.0 \\
\hline Corporate and other pension funds & & 305,510 & 5,337 & 108.1 \\
\hline Investment trust management companies & 171 & 196,752 & 1,808 & 36.6 \\
\hline $\begin{array}{l}\text { Stock market (listed companies, market } \\
\text { capitalization) }\end{array}$ & 3,552 & 580,720 & 5,338 & 108.1 \\
\hline Total debt securities outstanding & & $1,169,158$ & 10,745 & 217.7 \\
\hline Of which, local currency & & $1,132,301$ & 10,407 & 210.8 \\
\hline foreign currency & & 36,857 & 339 & 6.7 \\
\hline Government debt securities outstanding & & $1,061,389$ & 9,755 & 197.6 \\
\hline Of which, local currency & & $1,054,043$ & 9,688 & 196.2 \\
\hline foreign currency & & 7,346 & 68 & 1.4 \\
\hline Corporate debt securities outstanding & & 107,769 & 991 & 20.6 \\
\hline Of which, local currency & & 78,258 & 719 & 14.6 \\
\hline foreign currency & & 29,511 & 271 & 5.5 \\
\hline
\end{tabular}

Note: Data as of the end of March 2017, the end of the 2016-2017 fiscal year. Life insurance includes Japan Post insurance, $\$ 1=¥ 108.8$; GDP $=¥ 537,123$ trillion .

Sources: Bank of Japan, Japan Post Bank, Japan Finance Corporation, Japan Exchange Group, AsianBondsOnline

\section{Local Currency Bond Markets}

Japan transitioned during the 1990s to a disclosure-based capital market regime. All of the supporting infrastructure for bond issuance and trading is in place, with the JGB market being one of the most liquid in the world. The bond market in Japan is dominated by JGBs, which comprise about $93 \%$ of outstanding local currency debt securities (Figure A5). Corporate bonds have steadily declined in both nominal terms and relative to GDP since 1998 , amounting at the end of June 2017 to $¥ 78.5$ trillion, or about $15 \%$ of GDP, down from $¥ 127$ trillion and $24 \%$ of GDP in 1998. This reflects reduced capital investment through the extended period of economic stagnation.

Despite the size and diversity of institutional investors in Japan, investment portfolios tend to be very conservative, focusing to a large extent on JGB holdings. While this is changing, 


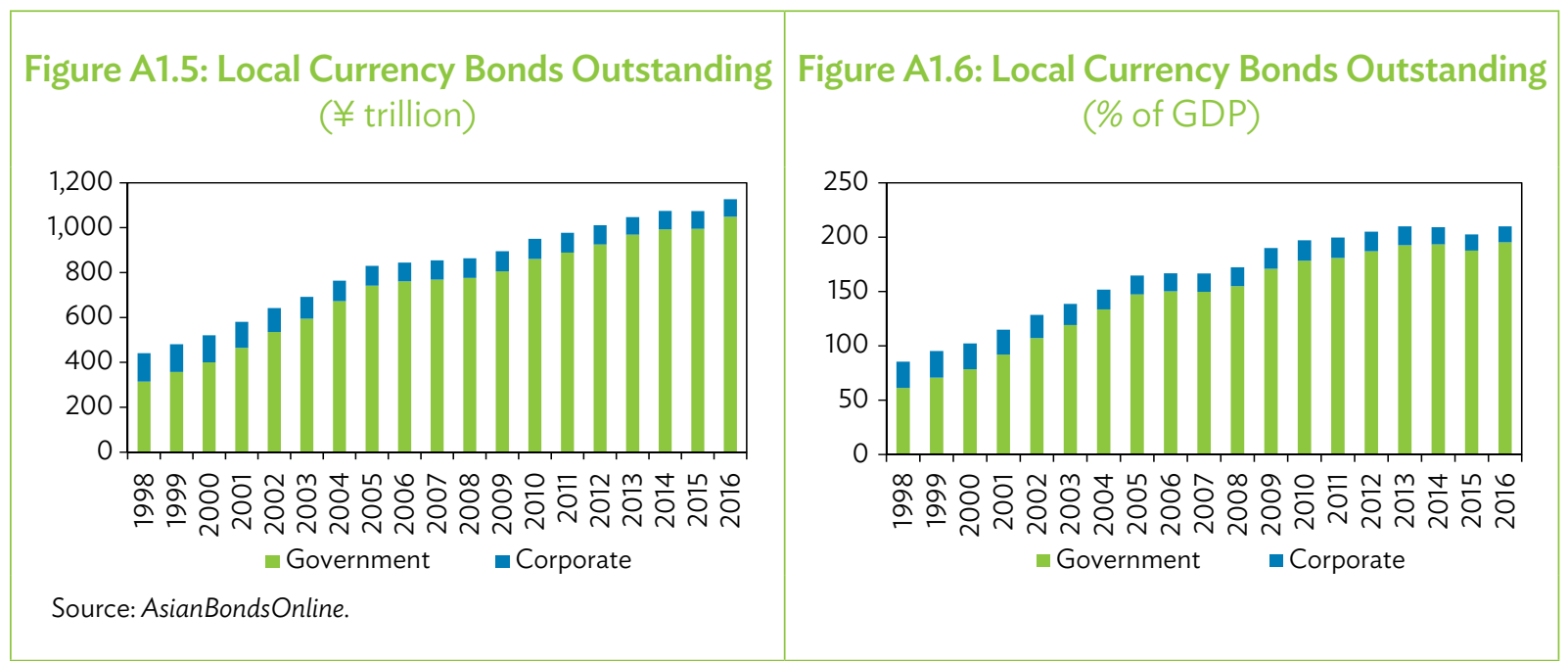

partially in response to reform efforts, there is limited demand for wider ranges of debt instruments and alternative asset classes.

The importance of responsible investing is increasing in Japan with the primary focus on the governance aspect of ESG. A stewardship code outlining the responsibilities of institutional investors for fostering, among other things, investee companies' sustainable growth, was introduced in 2014 and revised in 2017. About 200 institutional investors in Japan have voluntarily agreed to adhere to the code. Over time, this could create demand for instruments such as green bonds.

\section{Green Bonds}

Japan's Ministry of the Environment (MOE) has published guidelines for green bond issuance, reflecting the expectation that they would provide a vehicle to increase private investment in green projects. Issuance of the guidelines was motivated by the slow pace of green bond issuance, notwithstanding the major investment in renewable energy following the decision to cease nuclear power generation and Japan's signing in April 2016 of the Paris Climate Change Agreement of the CPO21. Japan requires significant investment to achieve its goals.

Japan's MOE 2017 guidelines, which are voluntary, are based on the 2016 version of the GBP. There is an indicative list of nine broad categories of green projects, generally aligned with the 2016 GBP. Second opinions are encouraged, as is a tracking and reporting mechanism for use of proceeds.

The Tokyo Metropolitan Government published in February 2017 a Green Bond Issuance Policy building on its 2016 Tokyo Environment Master Plan, which set goals including reduction in greenhouse gas emissions. ${ }^{9}$ Issuing green bonds is expected to achieve the following:

\footnotetext{
Tokyo Metropolitan Government. Green Bond Issuance Policy. http://www.zaimu.metro.tokyo.jp/bond/en/tosai_news
} _topics/news_topics/greenbond_290222_2.pdf. 
(i) promote new environmental measures for the realization of a smart city;

(ii) mobilize domestic savings for environmental measures and promote the green bond market, encouraging other issuers through the first local government green bond issue in Japan;

(iii) encourage a sense of ownership among Tokyo residents of the local government's environmental projects and offer the opportunity to directly participate in their financing;

(iv) promote corporate environmental awareness by offering institutional investors green investing opportunities; and

(v) diversify the investor base for Tokyo Metropolitan Government bonds.

A "beta" green bond was issued by the Tokyo Metropolitan Government in November 2016. This was an Australian dollar issue raising the equivalent of $¥ 10$ billion ( $\$ 92$ million), labeled as Tokyo Environmental Supporter Bonds. While generally following the GBP, these bonds did not have a second opinion. The Tokyo Metropolitan Government has announced plans to issue its first labeled green bonds late in 2017, intending to fully comply with the GBP including a second opinion. The green bonds are expected to be yen-denominated in line with the objective of mobilizing domestic savings.

The first green bond by an issuer in Japan was a foreign currency issue by the state-owned Development Bank of Japan in September 2014 (Table A6). About $¥ 30$ billion of climatealigned project bonds have been issued since 2013 for solar plants under the Mega Solar Project Bond Trust. Although by virtue of the pure play nature of the stand-alone solar projects the bonds were clearly climate-aligned, the Canadian Solar Gunma Aramaki Solar Power Plant issue in 2017 was the first labeled green project bond under the Mega Solar Project Bond structure.

\section{Table A1.6: Green Bond Issues in Japan}

\begin{tabular}{|c|c|c|c|}
\hline Issuer & Date & Currency and Size & Second Opinion \\
\hline $\begin{array}{l}\text { Canadian Solar Gunma } \\
\text { Aramaki Solar Power Plant }\end{array}$ & April 2017 & $¥ 5.4$ billion & Japan Research Institution \\
\hline Development Bank of Japan & $\begin{array}{c}\text { October } 2016 \\
\text { October } 2014 \\
\text { September } 2014\end{array}$ & $\begin{array}{l}\$ 500 \text { million } \\
€ 250 \text { million } \\
€ 300 \text { million }\end{array}$ & $\begin{array}{c}\text { Sustainalytics } \\
\text { DNV GL } \\
\text { Sustainalytics }\end{array}$ \\
\hline Mitsubishi UFG & September 2016 & $\$ 500$ million & Sustainalytics \\
\hline Nomura Research Institute & September 2016 & $¥ 10$ billion & Vigeo-Eiris \\
\hline Sumitomo Mitsui & October 2015 & $\$ 500$ million & None \\
\hline
\end{tabular}

Note: Toyota Financial Services green bonds are attributed to Japan in some sources, but the issuer is actually the US-domiciled financing arm of Toyota.

Sources: Canadian Solar; CBI data. https://www.climatebonds.net/cbi/pub/data/bonds (accessed 7 July 2017).

The Nomura Research Institute issue financed investments in qualifying green buildings. The other green issues in Japan are financial, with the banks using the proceeds to finance or refinance qualifying green assets. The Development Bank of Japan issue in October 2014 was dedicated to financing qualifying green buildings. 
All labeled green issues in Japan with the exception of Sumitomo Mitsui have second opinions. The Japan Research Institution is the only domestic firm to date to offer second opinion services.

The dollar- and euro-denominated green issues have been sold largely to international investors, with the yen issues being sold largely to domestic institutional investors. The Mega Solar Project Bond Trust is targeting primarily institutional investors in Japan with an appetite for project bonds but lacking the in-house capacity to assess individual small projects.

\section{F. Republic of Korea}

The Republic of Korea has large and well-developed financial and capital markets. In addition to a deposit-taking sector (including cooperative and savings banks) equivalent to more than $160 \%$ of GDP, the Republic of Korea is home to large pools of contractual savings. The national Pension Service is the third-largest pension fund in the world, with total assets of more than $\$ 450$ billion, equivalent to about one-third of GDP, and insurance companies have total assets equivalent to half of GDP. Stock market capitalization exceeds $90 \%$ of GDP.

The Financial Services Commission is the main prudential authority, responsible for oversight of banks, insurance companies, and a number of nonbank institutions. The Financial Supervisory Service is responsible for off-site monitoring and on-site examinations as required by the Financial Services Commission and the Securities and Futures Commission. The Bank of Korea also has a supervisory role and may conduct joint examinations with the Financial Supervisory Service. The Korea Deposit Insurance Corporation also has a supervisory role with respect to deposit-taking institutions.

The Securities and Futures Commission, established within the Financial Services Commission, is responsible for capital markets oversight. The Korean Financial Investment Association is an SRO of dealers and fund managers with a number of licensing, technical, and educational responsibilities in the fixed income market. The Financial Investment Services and Capital Market Act is the main law governing the capital markets, establishing a disclosure-based system. Bond issues are by prospectus with continuous disclosure requirements. Corporate bond issues require a rating by two agencies. Bonds may also be issued by private placement with up to 50 accredited investors.

\section{Local Currency Bond Markets}

The bond market in the Republic of Korea is the third largest in Asia after those of Japan and the PRC. Government debt has been relatively constant in the range of $40 \%-45 \%$ of GDP over the last decade. The corporate bond market has grown from about $50 \%$ to almost $75 \%$ of GDP over the last 15 years; however, this is somewhat deceptive as more than half of the 30 largest corporate issuers are government-owned entities, mostly financial and commercial businesses, but also including the Korea Deposit Insurance Corporation. 
Table A1.7: Republic of Korea Financial and Capital Markets Overview, 2016

\begin{tabular}{|c|c|c|c|c|}
\hline & Number & $\begin{array}{c}\text { Assets } \\
\text { (W billion) }\end{array}$ & $\begin{array}{c}\text { Assets } \\
\text { ( } \$ \text { billion) }\end{array}$ & $\begin{array}{c}\text { Assets } \\
\text { (\% of GDP) }\end{array}$ \\
\hline Commercial banks & & $1,653,795$ & 1,369 & 101.0 \\
\hline Insurance companies & & 818,710 & 677 & 50.0 \\
\hline Mutual credit cooperatives & & 622,219 & 515 & 38.0 \\
\hline Securities companies & & 392,981 & 325 & 24.0 \\
\hline Credit-specific financial companies & & 212,864 & 176 & 13.0 \\
\hline Savings banks & & 49,122 & 40 & 3.0 \\
\hline Postal Savings Bureau & 1 & 6,625 & 5 & 0.4 \\
\hline National Pension Service & 1 & 546,000 & 452 & 33.4 \\
\hline Listed companies (market capitalization) & 2059 & $1,548,471$ & 1,282 & 94.6 \\
\hline Government debt securities outstanding & & 882,596 & 730 & 53.9 \\
\hline Of which, local currency & & 847,537 & 701 & 51.8 \\
\hline foreign currency & & 35,059 & 29 & 2.1 \\
\hline Corporate debt securities outstanding & & $1,364,890$ & 1,130 & 83.4 \\
\hline Of which, local currency & & $1,218,916$ & 1,009 & 74.4 \\
\hline foreign currency & & 145,974 & 120 & 8.9 \\
\hline
\end{tabular}

Notes: Data as of the end of 2016. 1\$=W1,208; GDP = W1,637,420 billion.

Sources: Bank of Korea. 2016. Financial Stability Report. December; Sustainable Stock Exchanges Initiative; Korea Post; National Pension Service; IMF Country Report No. 16/278; AsianBondsOnline.

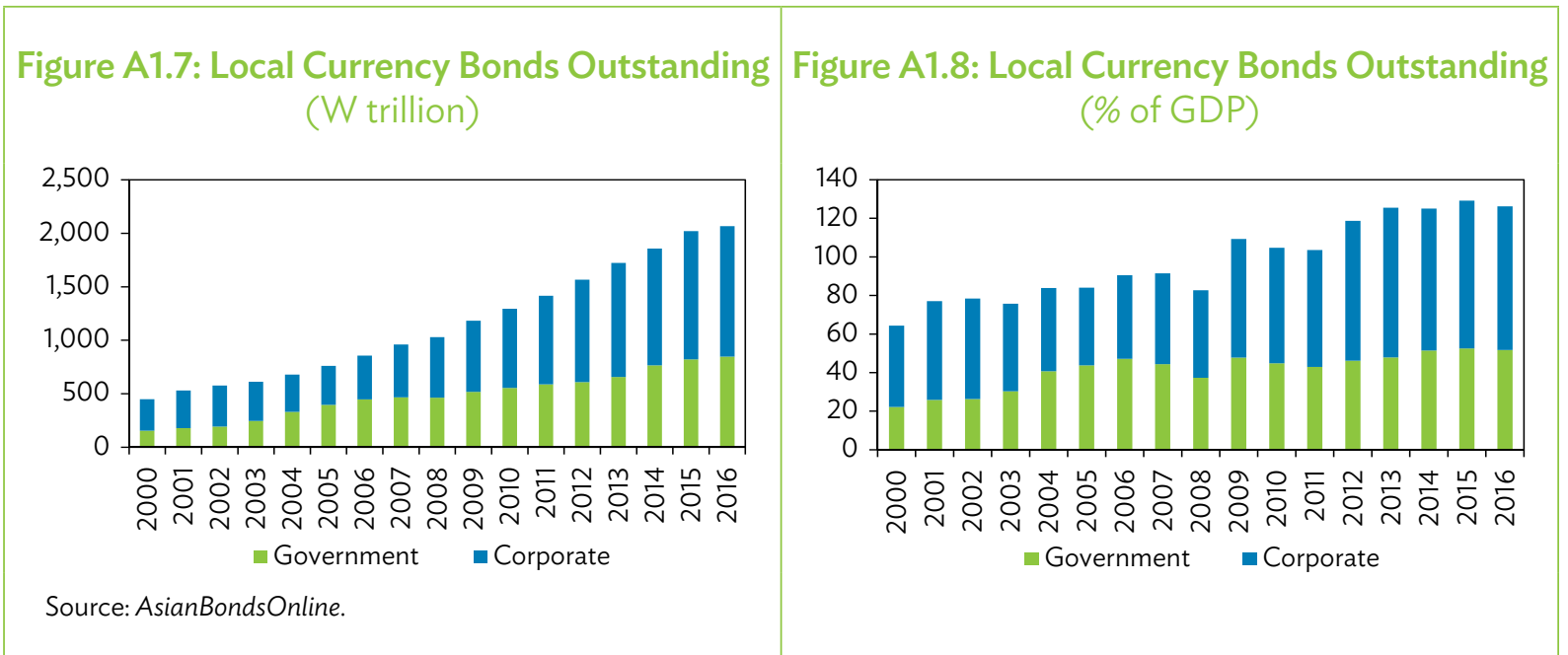

\section{Green Bonds}

A high-level government priority for sustainable growth was established through the Framework Act on Low Carbon and Green Growth, 2010. Environmental issues are expected to take on a higher priority under the new government. Market participants 
believe further government action will be required to promote green bonds, particularly in raising awareness of the issues and promoting SRI investment practices.

There have been no local currency green bond issues to date, but there had been four US dollar issues by three issuers through the end of July 2017 (Table A8). Despite these issues, there is limited awareness in the domestic market of green bonds. There is as yet no domestic green bond expertise, with the underwriters and second opinion providers for the green bond issues being well-known international firms.

\section{Table A1.8: Republic of Korea Green Bond Issues}

\begin{tabular}{l|l|l|l} 
& \multicolumn{1}{|c|}{ Date } & $\begin{array}{c}\text { Currency and } \\
\text { Size }\end{array}$ & Second Opinion \\
\hline Korea Development Bank & July 2017 & $\$ 300$ million & Sustainalytics \\
\hline Export-Import Bank of Korea & February 2016 & $\$ 400$ million & CICERO \\
& February 2013 & $\$ 500$ million & CICERO \\
\hline Hyundai Capital Services & February 2016 & $\$ 500$ million & none \\
\hline
\end{tabular}

Sources: Korea Development Bank; CBI data. https://www.climatebonds.net/cbi/pub/data/bonds (accessed 7 July 2017).

Currently there are few dedicated ESG investors or funds, and no evident demand from the public for institutional investors to consider ESG factors. The National Pension Act of Korea requires the National Pension Scheme to consider ESG issues and declare the extent to which they are taken into account. This makes the National Pension Scheme a potential catalyst given its size and that it is a signatory to the UNPRI.

The Export-Import Bank of Korea issued the inaugural Korean green bond in 2013, followed by a second issue in 2016. Proceeds of both issues are dedicated to qualifying activities, primarily renewable energy, in foreign projects where Korean companies play a major role. In addition to aligning with broad government policy, one of the motivations was to help the international competitiveness of firms in the Republic of Korea by providing green financing. Broadening the investor base was also a factor, with about $60 \%$ of the inaugural issue purchased by 13 investors with SRI mandates. The second issue attracted about 30 SRI investors, but they accounted for only $30 \%$ of the allocation. The majority of both issues were placed with non-Asian investors. The first issue was priced to yield about 5 bps less than a comparable non-green issue, while the second was priced flat relative to other Export-Import Bank of Korea issues.

The Hyundai Capital Services issue is dedicated to financing Hyundai and Kia hybrid and electric cars. Although it does not have a second opinion, the issue has been accepted as green by most investors, relying on the company's assurance that all of the hybrid vehicles financed produce a maximum of 110 grams of carbon dioxide per passenger-kilometer traveled. This is above the threshold of 85-90 specified in the CBI Standard, but the issue has been included in the CBI green database. ${ }^{10}$

10 Corporate Bonds Initiative. Corporate Green Bonds. https://www.climatebonds.net/2016/03/green-bond-market -report-korea-hyundai-inaugural-500m-hybrids-evs-china-bank-qingdao-rmb-4bn (accessed 18 August 2017). 


\section{G. Lao People's Democratic Republic}

The bank-denominated financial sector of the Lao People's Democratic Republic (Lao PDR) has been evolving rapidly as new privately owned and joint venture financial institutions have entered the market. State-owned banks continue to comprise about half of the system and, in common with some of the privately owned banks, have been hampered by poor asset quality and undercapitalization." Dollarization is high, with close to half of deposits and credit to the private sector denominated in foreign currencies, although this marks a decline from 2000 when about three-quarters of all deposits were denominated in a foreign currency.

\section{Table A1.9: Lao People's Democratic Republic Financial and Capital Markets Overview, 2016}

\begin{tabular}{|l|c|c|c|c} 
& Number & $\begin{array}{c}\text { Assets } \\
(\text { KN billion })\end{array}$ & $\begin{array}{c}\text { Assets } \\
(\$ \text { billion })\end{array}$ & $\begin{array}{c}\text { Assets } \\
\text { (\% of GDP) }\end{array}$ \\
\hline Banks & 33 & 113,156 & 13.6 & 100.9 \\
\hline $\begin{array}{l}\text { State-owned commercial and specialized } \\
\text { banks }\end{array}$ & 4 & 49,836 & 6.0 & 44.4 \\
\hline Joint venture banks & 3 & $11,212.96$ & 1.4 & 10.0 \\
\hline Private banks & 7 & 20,807 & 2.5 & 18.5 \\
\hline Branches of foreign banks & 19 & 31,300 & 3.8 & 27.9 \\
\hline Listed companies (market capitalization) & 5 & 12,047 & 1.5 & 10.7 \\
\hline Insurance companies & 3 & & & \\
\hline
\end{tabular}

Notes: Data as of the end of 2016 except listed companies and market capitalization (as of the end of 2015). $1 \$=\mathrm{KN} 8,300, \mathrm{GDP}=\mathrm{KN} 112,188$ billion .

Sources: Bank of the Lao PDR, Lao Securities Exchange, IMF Country Report No. 17/53 (February 2017).

The Bank of the Lao PDR is the prudential authority responsible for oversight of the banking system. The Ministry of Finance is the insurance regulator. The legal framework for capital markets regulation was established in 2010 with the Decree on Securities and Exchanges. The Securities and Exchange Commission of the Lao PDR was established as the supervisory authority to formulate and amend necessary strategic plans, policies, and laws relating to securities activities. In 2013, it was renamed Lao Securities Commission (LSC). The policy development and supervisory activities of the LSC are undertaken by the Lao Securities Commission Office, as a secretariat the LSC.

Nonbank financial institutions are at an early stage of development. There are only a few small insurers, none of which offer life insurance products. The Lao Securities Exchange (LSX), a joint venture of the Bank of the Lao PDR and the Korea Exchange, was established in 2010, had six listed companies at the end of November 2017. Government and corporate bond markets are still at an early stage of development. LSX has developed the systems for bond trading, clearing and settlement, depository and some legislation and related

11 International Monetary Fund. 2017. Lao People’s Democratic Republic Article IV Consultation. Washington, DC. 
regulations. In addition, a steering committee has been formed to encourage government bond to trade through LSX. Green bond issuance is a long-term objective for the Lao PDR to be addressed after local currency bond markets emerge.

\section{H. Malaysia}

Malaysia has well developed financial and capital markets, with total banking assets approaching 200\% of GDP. In addition to stock market capitalization equal to $135 \%$ of GDP, Malaysia accounted for almost half of global sukuk issuance in 2016. ${ }^{12}$ Local currency sukuk and bond issues have continued to grow and Malaysia has successfully attracted many international issuers, primarily for sukuk.

\section{Table A1.10: Malaysia Financial and Capital Markets Overview, 2016}

\begin{tabular}{|l|c|c|c|c}
\hline & Number & $\begin{array}{c}\text { Assets } \\
\text { (RM billion) }\end{array}$ & $\begin{array}{c}\text { Assets } \\
\text { (\$ billion) }\end{array}$ & $\begin{array}{c}\text { Assets } \\
\text { (\% of GDP) }\end{array}$ \\
\hline Banks (commercial, investment, and Islamic) & 55 & 2,443 & 544 & 198.6 \\
\hline Insurance companies (includes takaful) & 56 & 272 & 60 & 22.1 \\
\hline Fund management companies & 74 & 696 & 155 & 56.6 \\
\hline Private retirement schemes & 8 & 2 & 0.3 & 0.1 \\
\hline Employees Provident Fund & 1 & 742 & 165 & 60.3 \\
\hline Retirement Fund (KWAP) & 1 & 130 & 29 & 10.6 \\
\hline Listed companies (stock market & & & & \\
\hline capitalization) & 904 & 1,667 & 371 & 135.5 \\
\hline Government debt securities outstanding & & 680 & 151 & 55.3 \\
\hline Of which, local currency & & 634 & 141 & 51.5 \\
\hline \multicolumn{1}{|c|}{ foreign currency } & & 46 & 10 & 3.8 \\
\hline Corporate debt securities outstanding & & 667 & 148 & 54.2 \\
\hline Of which, local currency & & 534 & 119 & 43.4 \\
\hline foreign currency & & 133 & 29 & 10.8 \\
\hline
\end{tabular}

Notes: $1 \$=$ RM4.49, GDP = RM1,230 billion.

Sources: AsianBondsOnline, Bank Negara Malaysia, Employees Provident Fund (KWSP), Retirement Fund (KWAP), Securities Commission Malaysia, Private Pension Administrator Malaysia (PPA), Capital Markets Malaysia.

Bank Negara Malaysia is the main prudential authority with supervisory responsibility for banks and insurance companies. The Securities Commission (SC) is the principal capital markets regulator, with responsibility for the licensing and oversight of individuals and institutions undertaking capital markets activities, oversight of exchanges and central depositories, and approval of the issue of securities. Bursa Malaysia, the stock exchange,

12 Malaysia International Islamic Financial Centre. 2017. 2016 Global Sukuk Market: A Record Year for Corporate Issuance. 27 March. http://www.mifc.com/index.php?rp=sukuk_report_270317.pdf. 
has delegated authority from the SC for market surveillance and disclosure requirements for listed companies.

\section{Local Currency Bond Markets}

The Guidelines on Issuance of Corporate Bonds and Sukuk to Retail Investors and the Guidelines on Unlisted Capital Market Products under the Lodge and Launch Framework issued by the SC provide a succinct summary of the requirements for issuance of any corporate bond, medium-term note, commercial paper, or debt program as well as sukuk. The Islamic Securities Guidelines provide parallel guidance for sukuk. The Shariah Advisory Council established by the SC has played an important role in the development of the Islamic capital market. The Shariah Advisory Council takes precedence over the advisory councils of individual issuers and has contributed to establishing precedents and standardization, facilitating the growth of the market.

The breadth and depth of the Malaysian bond markets reflect concerted development efforts since the 1999 commencement of work on the first Capital Market Masterplan. The slight decline in the size of the local currency bond market relative to GDP since 2011 reflects declining government debt-corporate bonds and sukuk have continued to grow both in nominal terms and relative to GDP (Figures A9, A10). In common with other countries with well-developed bond markets, contractual savings and the fund management business is well established, providing a range of large domestic institutional investors.

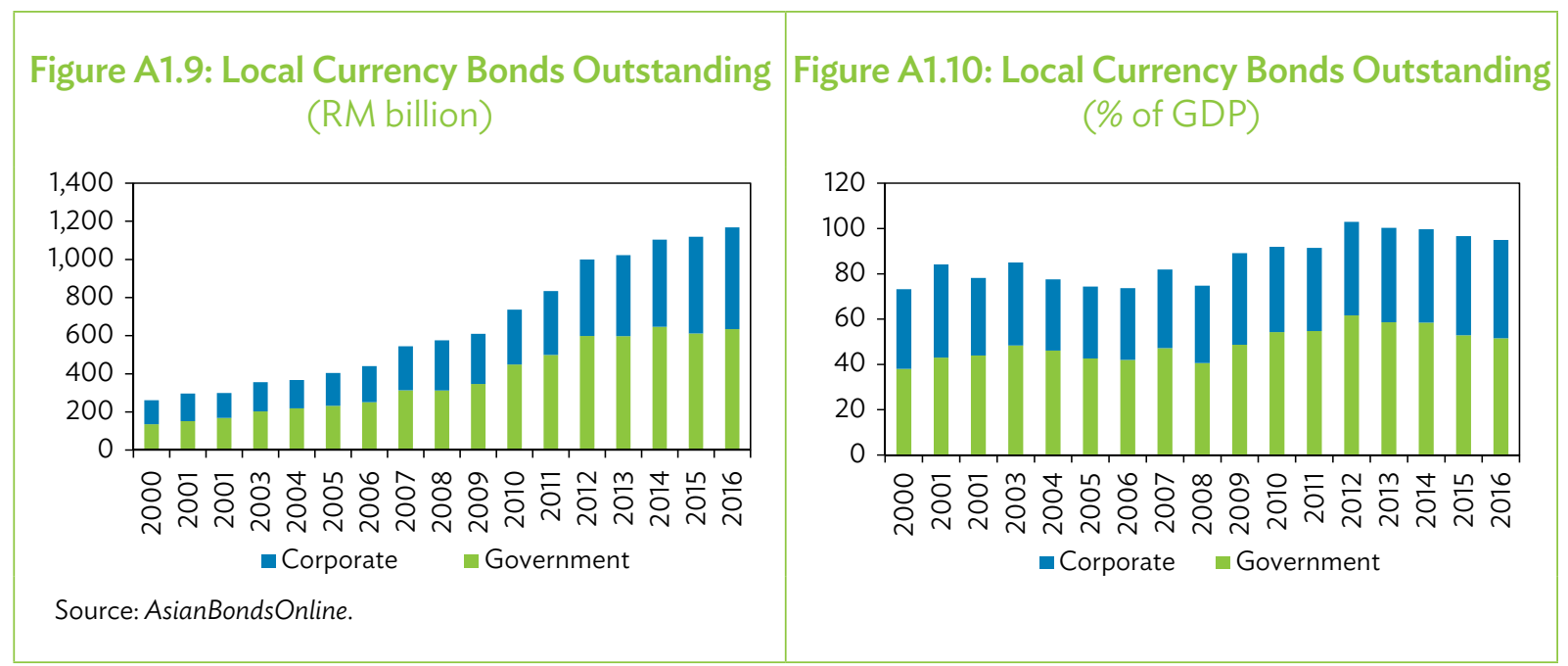

\section{Green Bonds}

The SC is co-chair (with the Philippines) of the ACMF ASEAN Green Bond Initiative group working on green bond standards, and thus has a much higher level of knowledge of green bonds than many other authorities in the region. Institutional investors in Malaysia have a generally higher awareness of ESG than in most other ASEAN+3 countries, but still have little familiarity with green bonds. 
Amendments were introduced in November 2017 to the SC's Guidelines on Issuance of Corporate Bonds and Sukuk to Retail Investors, introducing additional requirements for an issuance of ASEAN green bonds or sukuk. In December 2017, the Guidelines on Sustainable and Responsible Investment (SRI) Funds introduced additional disclosure and reporting requirements to encourage greater transparency by SRI funds.

Malaysian institutional investors tend to focus solely on returns as there is no pressure from clients to look at ESG. Two Malaysian investors have signed the UNPRI, state-owned Khazanah and a small private firm, Corston-Smith Asset Management. Market participants see many opportunities to issue green bonds and sukuk, but expect that issuers will only do so if there is an incentive to offset the increased issuance costs. The SC had introduced an SRI sukuk framework in 2014 to provide standards for SRI, which encompasses green financing. The guidelines are high level, but generally aligned with the GBP. They require the following of issuers:

(i) ensure the proceeds are used for eligible SRI projects;

(ii) disclose details of the eligible SRI project and, to the extent possible, impact objectives from the project;

(iii) provide a statement that the issuer has complied with the relevant environmental, social, and governance standards or recognized best practices relating to the project; and

(iv) provide annual reporting - via newsletters, website updates, an annual report, or any other communication channels-to investors on the

(a) original amount earmarked for the SRI project,

(b) amount utilized for the SRI project,

(c) unutilized amount and where such unutilized amounts are placed or invested pending utilization, and

(d) impact objectives from the eligible SRI project (where feasible and to the extent possible).

The list of eligible green projects under the SRI sukuk framework differs from the nine specific categories in the GBP, but is broadly similar in approach. Eligible projects include the following:

(i) natural resources projects relating to

(a) sustainable land use,

(b) sustainable forestry and agriculture,

(c) biodiversity conservation,

(d) remediation and redevelopment of polluted or contaminated sites,

(e) water infrastructure, treatment and recycling, and

(f) sustainable waste management projects; and

(ii) renewable energy and energy efficiency projects relating to

(a) new or existing renewable energy (solar, wind, hydro, biomass, geothermal, and tidal);

(b) efficient power generation and transmission systems; and

(c) energy efficiency that results in the reduction of greenhouse gas emissions or energy consumption per unit output. 
Most projects qualifying under the Malaysian SRI sukuk framework would likely be considered green under the GBP.

The SRI sukuk framework provided a foundation for the first green sukuk issued in Malaysia and the world in July 2017. Tadau Energy Sdn. Bhd. issued a RM250 million ( $\$ 58$ million) green sukuk to finance construction of a solar generation project. Green SRI Sukuk Tadau is a project sukuk, with the project entity sponsored by Edra Power Holdings Sdn. Bhd., a Malaysian firm with a PRC-domiciled parent. Project cash flow is provided by two 21-year power purchase agreements with Sabah Electricity Sdn. Bhd., jointly owned by the government-owned power grid and the state government of Sabah. Affin Hwang Investment Bank Berhad, a Malaysian-domiciled investment bank with sukuk underwriting experience, but no prior green credentials, was the principal advisor and lead arranger for the issue, which was rated AA3 by RAM Rating Services. A second opinion was provided by CICERO. There is no publicly available information on the investors, but they likely include the major Malaysian institutional investors that have traditionally invested in project sukuk.

In its 2018 budget, the government announced a RM6 million Green SRI Sukuk Grant Scheme to allow issuers to offset the external review costs incurred on applications received by the SC from 1 January 2018 to 31 December 2020. Existing tax deductions for SRI sukuk issuance and investing in green technology appear to provide incentives for the issuance of green sukuk, but there seems to be little awareness of these potential tax advantages among market participants. A tax deduction for the issuance costs of SRI sukuk approved by the SC is available until 2020. In addition, there are two tax incentive programs to encourage investment in renewable energy, the Green Investment Tax Allowance and Green Income Tax Exemption, which may enhance the financial viability of green projects and thus contribute to green sukuk or bond financing.

\section{Myanmar}

The financial sector in Myanmar has been evolving rapidly, with the number of banks expanding by more than $50 \%$ over the last 3 years through the entry of new domestically and foreign-owned private banks. This has reduced the market share of the state-owned banks, although they still comprise about half of the banking system. Despite progress with financial liberalization, administered interest rates, including a floor on deposit rates and a cap on loan rates, remain in place, inhibiting growth of credit to the private sector. There are 12 small locally owned insurers as well as state-owned Myanmar. While nine of the 12 have composite licenses, there is virtually no life insurance underwritten.

A new Financial Institutions Law was enacted in 2016, but a number of key implementing regulations remain outstanding. The central bank is the prudential supervisor for banks, with insurance falling under the oversight of Insurance Business Supervisory Board, part of the Ministry of Finance. The Securities and Exchange Law was enacted in 2013, with the Securities Exchange Commission of Myanmar established as the capital markets regulator in August 2014. Initial steps toward developing the capital markets have included the launch of Treasury bond auctions and the expansion of auction participants to include foreign banks. Continuation of financial reform and liberalization will be required for local currency bond markets to develop, making green bonds a long-term objective. 
Table A1.11: Myanmar Financial and Capital Markets Overview, 2016

\begin{tabular}{|l|c|c|c|c} 
& Number & $\begin{array}{c}\text { Assets } \\
\text { (MK billion) }\end{array}$ & $\begin{array}{c}\text { Assets } \\
\text { (\$ billion) }\end{array}$ & $\begin{array}{c}\text { Assets } \\
\text { (\% of GDP) }\end{array}$ \\
\hline Banks & 41 & 50,445 & 36.6 & 68.8 \\
\hline State-owned banks & 4 & 17,974 & 13.0 & 24.5 \\
\hline Private banks & 24 & 28,401 & 20.6 & 38.7 \\
\hline Foreign banks & 13 & 4,069 & 2.9 & 5.6 \\
\hline Listed companies (market capitalization) & 3 & 584 & 0.4 & 0.8 \\
\hline Government securities outstanding & & 4,448 & 3.2 & 6.1 \\
\hline Treasury bills & & 1,223 & 0.9 & 1.7 \\
\hline Treasury bonds & & 4,225 & 2.3 & 4.4 \\
\hline
\end{tabular}

Notes: $\$ 1$ = MK1,293; GDP = MK56,635 billion.

Sources: Central Bank of Myanmar.

\section{J. Philippines}

Financial and capital markets in the Philippines have been growing strongly, although the system overall remains bank dominated and highly concentrated. Seven of the 10 largest banks, accounting for about $60 \%$ of bank assets, are affiliated with domestic conglomerates that collectively account for a large share of the Philippine stock exchange market capitalization. ${ }^{13}$ Nonbank intermediaries, including insurance and pension firms, and the fund management business, remain quite small relative to GDP and compared to countries with larger local currency bond markets.

The Bangko Sentral ng Pilipinas (BSP) is the prudential supervisor for banks and nonbank deposit-taking institutions. The BSP oversight of deposit-taking institutions includes the issuance of debt securities by licensed banks; the operation of trust accounts, which include individual investment accounts; and the manufacture and distribution of unit investment trust funds, a type of mutual fund. The BSP also registers foreign investments, including portfolio investment, and monitors capital flows into and out of the Philippines. Local currency bonds issued offshore by private sector residents (without government guarantee) and nonresidents, requires prior registration with the BSP. Prior BSP approval is required for offshore issuance of local currency bonds by public sector issuers, or private sector issuers with a public guarantee, and for nonresidents' onshore issuance of local currency bonds.

The Insurance Commission is responsible for the oversight of insurance companies. The Department of Finance is responsible for most aspects of the regulation and oversight of Philippine capital markets but delegates day-to-day responsibilities to a variety of primarily government bodies. The Securities and Exchange Commission oversees corporate bond issuance and secondary trading, and also has responsibility for mutual funds (but not

3 A.M. Andrews and P. Braginetz. 2015. Local Currency Bonds and Infrastructure Finance in ASEAN+3. Manila: ADB. 
unit investment trust funds). The Philippine Dealing and Exchange Corporation is an SRO recognized by the Securities and Exchange Commission to operate an electronic fixed income trading platform and market liquidity programs (securities lending and repo activities), and to develop and enforce fixed income trading rules.

Table A1.12: The Philippines Financial and Capital Markets, 2016

\begin{tabular}{|c|c|c|c|c|}
\hline & Number & $\begin{array}{c}\text { Assets } \\
\text { (P billion) }\end{array}$ & $\begin{array}{l}\text { Assets } \\
\text { ( } \$ \text { billion) }\end{array}$ & $\begin{array}{c}\text { Assets } \\
\text { (\% of GDP) }\end{array}$ \\
\hline Banks & 602 & 13,591 & 272.8 & 93.9 \\
\hline Insurance companies & 101 & 1,165 & 23.4 & 8.0 \\
\hline Government Service Insurance System & 1 & 1012 & 20.3 & 7.0 \\
\hline Social Security System & 1 & 476 & 9.6 & 3.3 \\
\hline Unit Investment Trust Funds & & 720 & 14.5 & 5.0 \\
\hline Mutual funds & & 256 & 5.2 & 1.8 \\
\hline Variable Unit Linked funds & & 441 & 8.9 & 3.0 \\
\hline Listed companies (market capitalization) & 265 & 14,438 & 289.9 & 99.7 \\
\hline Total debt securities outstanding & & 6,900 & 138.8 & 47.7 \\
\hline Of which, local currency & & 4,869 & 98.0 & 33.6 \\
\hline foreign currency & & 2,031 & 40.8 & 14.0 \\
\hline Government debt securities outstanding & & 5,429 & 109.1 & 37.5 \\
\hline Of which, local currency & & 3,978 & 80.0 & 27.5 \\
\hline foreign currency & & 1,451 & 29.1 & 10.0 \\
\hline Corporate debt securities outstanding & & 1,470 & 29.6 & 10.2 \\
\hline Of which, local currency & & 891 & 18.0 & 6.2 \\
\hline foreign currency & & 579 & 11.6 & 4.0 \\
\hline
\end{tabular}

Notes: $\$ 1$ = P49.8; GDP = P14,480 billion.

Sources: Bangko Sentral ng Pilipinas; Insurance Commission; Government Service Insurance System; Social Security System; Philippine Stock Exchange; AsianBondsOnline; Guide to Investment Funds. 2017. http://www .entrepreneur.com.ph/download/2017\%20Investment\%20Guide\%20Report\%20PDF\%20V8.pdf.

The Philippine Stock Exchange, through its subsidiary the Capital Markets Integrity Corporation, has SRO functions including rule-making and enforcing the Securities Regulation Code and its implementing rules and regulations, the Anti-Money Laundering Law and its implementing rules and regulations, and the Code of Conduct and Professional Ethics for Traders and Salesmen. The Bureau of the Treasury is responsible for public debt management including the issuance of government debt securities and for policy related to capital market development.

\section{Local Currency Bond Markets}

The second Philippines Capital Markets Development Plan, 2013-2017 includes five priorities for the fixed income market: 
(i) bond market liquidity enhancement,

(ii) development of private debt issues market,

(iii) institutionalization of hedge and protection markets,

(iv) strengthening clearing and risk management of securities and currencies, and

(v) regional cooperation.

A number of obstacles to bond market development have been addressed under the current Capital Markets Development Plan and its predecessor. However, elements of the tax regime continue to be unfavorable. Withholding tax generally applies on bond interest, however some large investors such as government entities are exempt, creating a bifurcated market. A work-around to overcome the price differential for trading between exempt and nonexempt investors has been introduced for government securities in which settlement occurs with the required tax withheld and tax-exempt firms then reimbursed. However, the bifurcated market remains unaddressed for corporate bonds. Despite extensive discussion, the documentary stamp tax still applies to certain secondary market activities including repos, which discourages trading.

Corporate bond issues have been increasing, but outstanding amounts remain very small, equivalent to about $5 \%$ of total bank assets or $6 \%$ of GDP (Figure A12). One reason is that Philippine banks tend to lend aggressively to the large conglomerates even at long tenors, thus providing little incentive for corporate treasurers to tap the bond market. Market participants indicated that this may be changing as the BSP has been seen to more stringently enforce concentration risk limits. As the conglomerates and their related entities bump up against banks' single borrower limits, there may be greater interest in corporate bonds.

Banks are the largest purchasers of bonds, however, a significant portion of their purchasers are for investors in unit investment trusts, rather than for the bank's own account. This helps to mitigate the challenge posed by the relatively small size of contractual savings by providing an additional institutional demand which compares in size to the social security system.

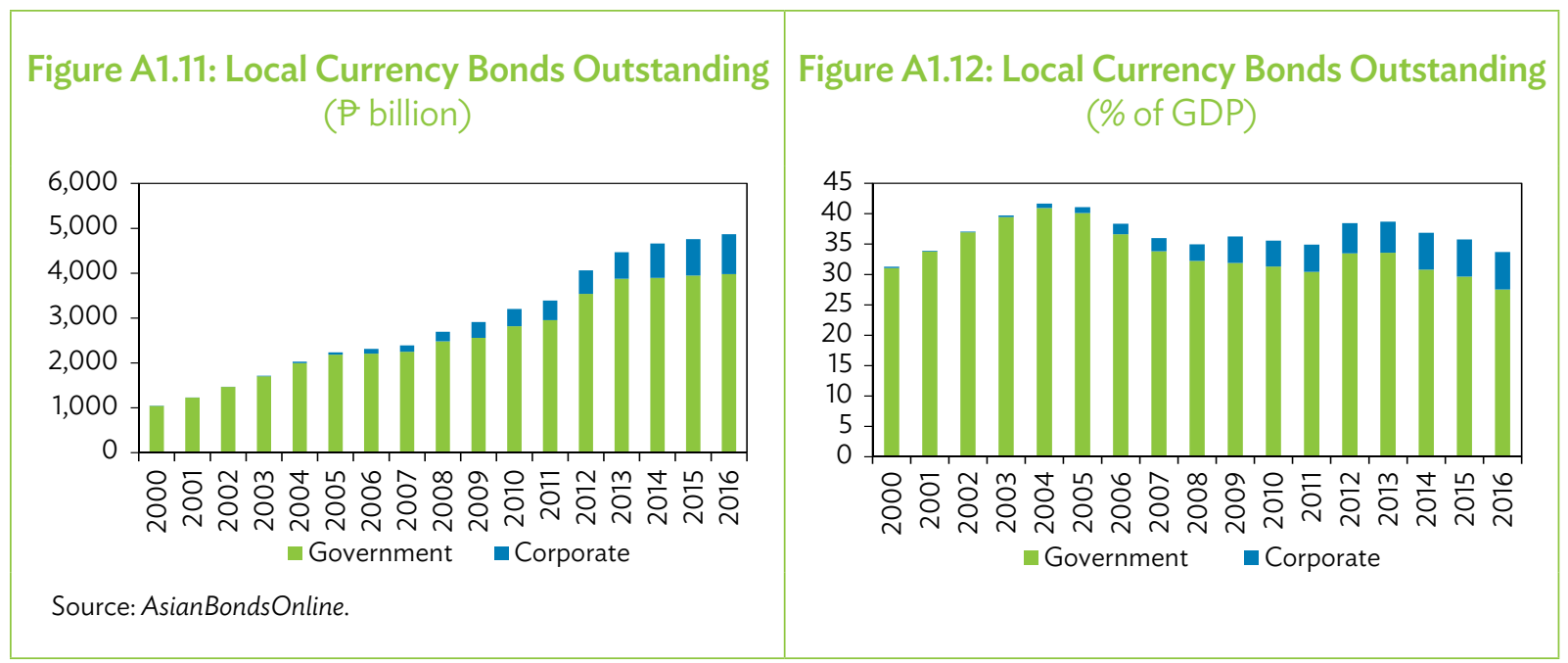




\section{Green Bonds}

The Philippines Securities and Exchange Commission is co-chair (with Malaysia) of an ACMF Green Bond Initiative group working on ASEAN green bond standards, and thus has greater awareness of the subject than many other authorities in the region. However, knowledge of green bonds among market participants, excluding those involved with the inaugural Philippines green bond issue, remains quite limited.

Philippine market participants see ample potential to issue green bonds for renewable energy and low-carbon transport, but do not anticipate rapid growth in issuance. There is no demand from domestic investors, and issuers see it as an unnecessary cost to raise capital. There is large unmet demand for corporate bonds among domestic institutional investors, so issuers have little interest in incurring the additional costs for green issues when they will be able to place non-green issues without difficulty. Both issuers and investors tend to view ESG and CSR as largely public relations exercises.

The inaugural (and through middle of 2017, the only) Philippine green bond was issued by AP Renewables, a geothermal pure play entity owned by Aboitiz Power, part of the Aboitiz conglomerate group. AP Renewables had acquired the Tiwi and Makiling-Banahaw (MakBan) geothermal facilities in a 2009 privatization. After investment in performance improvements, Aboitiz sought financing to take out its original equity investment. ADB proposed including green bonds in the financing package, viewing the project as a potential template for other renewable energy projects.

The 2016 financing package included a P10.7 billion ( $\$ 225$ million) local currency green bond, an ADB loan of P1.8 billion ( $\$ 37.7$ million), and an ADB and CGIF credit enhancement in the form of a guarantee of $75 \%$ of bond principal and interest. The involvement of $A D B$ and CGIF required higher standards for social safeguards, particularly in dealing with "informal settlers" on the project properties, than would have been required in the more usual financing by a consortium of local banks. ${ }^{14}$

AP Renewables would not have considered a green bond without the catalytic involvement of ADB. In addition to promoting the concept, ADB provided technical assistance in developing the green bond framework and offset the cost for the second opinion by DNV$\mathrm{GL}$. The AP Renewables bond was the catalyst for the development of the CBI Geothermal Standard. ADB encouraged adherence to the more stringent $C B I$ Standard rather than simply the GBP; however, the geothermal standard had not been issued by $C B I$ as the time of initial discussion of the AP Renewables green bond issuance.

AP Renewables' senior management was pleasantly surprised by the nonfinancial benefits to the green bond issue. The higher standard for social safeguards arising from ADB and CGIF involvement and the publicity of having issued a gold standard green bond were viewed as having a positive effect on the broader Aboitiz group's relationships with international institutional investors who place much higher priority on ESG issues than Philippines domestic investors. Due to the assistance of ADB, the only additional cost to 
AP Renewables was the internal cost for developing and implementing the green bond framework, which was relatively straightforward given the pure play nature of the Tiwi MakBan installations. Completing the financing arrangements took longer than the more typical Philippine bank consortium financing, attributed in large part by AP Renewables to $\mathrm{ADB}$ and CGIF processing requirements.

The underwriter priced the issue aggressively, possibly for the prestige of doing the first Philippines green bond issue. Unusually for a Philippine corporate issue, the underwriter continued to hold the bonds on its own book more than a year after initial issuance. The pricing of subsequent Philippines green bond issues is unlikely to be as favorable for the issuer.

\section{K. Singapore}

Singapore is a regional financial services hub with highly developed financial and capital markets. Its large banking and funds management firms reflect its regional role, as does its stock market capitalization of more than $200 \%$ of GDP (Table A13). Funds managed in Singapore play a significant role in providing corporate finance throughout the region. Thus, in addition to having a well-developed domestic market, Singapore is a source of capital and expertise for other ASEAN countries. The Government Investment Corporation

\section{Table A1.13: Singapore Financial and Capital Markets Overview, 2016}

\begin{tabular}{|l|c|c|c|c|}
\hline & Number & $\begin{array}{c}\text { Assets } \\
\text { (S\$ billion) }\end{array}$ & $\begin{array}{c}\text { Assets } \\
(\$ \text { billion) }\end{array}$ & $\begin{array}{c}\text { Assets } \\
\text { (\% of GDP) }\end{array}$ \\
\hline Banksa & 128 & 1,146 & 792 & 279.3 \\
\hline Insurance companies & 181 & 210 & 145 & 51.3 \\
\hline Government Investment Corporation & 1 & 462 & 320 & 112.8 \\
\hline Temasek & 1 & 447 & 309 & 109.1 \\
\hline Central Provident Fund & 1 & 332 & 229 & 81.0 \\
\hline Listed companies (market capitalization) & 757 & 926 & 640 & 225.7 \\
\hline Total debt securities outstanding & & 410 & 284 & 100.1 \\
\hline Of which, local currency & & 333 & 230 & 81.2 \\
\hline \multicolumn{1}{|c|}{ foreign currency } & & 77 & 53 & 19.0 \\
\hline Government debt securities outstanding & & 193 & 133 & 47.0 \\
\hline Of which, local currency & & 193 & 133 & 47.0 \\
\hline \multicolumn{1}{|c|}{ foreign currency } & & 0 & 0 & 0.0 \\
\hline Corporate debt securities outstanding & & 217 & 150 & 53.1 \\
\hline Of which, local currency & & 140 & 96 & 34.1 \\
\hline foreign currency & & 77 & 53 & 19.0 \\
\hline
\end{tabular}

\footnotetext{
a Assets for domestic banking units.
}

Note: Data as of the end of 2016 except for Temasek (as of the end of March 2017). $\$ 1$ = \$\$1.45; GDP= \$ \$410 billion. Sources: Monetary Authority of Singapore; Ministry of Trade and Industry Singapore; Temasek (Temasek Review 2017); Central Provident Fund; Singapore Exchange; PWC (Sovereign Investors 2020); AsianBonds Online. 
and Temasek are two of the largest sovereign wealth funds in the world, with extensive investments domestically and abroad.

Singapore's capital markets are among the most open in the world. Foreign institutions face few barriers to investing in Singapore dollar securities or establishing operations in Singapore. The government has actively sought to attract foreign firms to establish significant operations in Singapore with a variety of tax incentives and by providing financial institutions considerable flexibility in staffing their operations from local and expatriate communities.

The Singapore bond market, and the financial and capital markets at large are regulated and supervised by the MAS, an integrated regulatory authority. The Securities and Futures Act (2001) is the primary legislation governing Singapore's capital markets. In addition, debt securities listed on the SGX are subject to the rules and regulations on listing, trading, clearing, and settlement issued by the SGX. The MAS works closely with other government agencies and financial institutions to develop and promote Singapore as an international financial center, including Singapore's deep and liquid capital markets.

\section{Local Currency Bond Markets}

Despite running a budget surplus most years, Singapore has a well-developed government bond issuance program intended to support the financial and capital markets. Government debt securities are issued to provide instruments to enable financial institutions to meet statutory liquidity requirements and to provide a benchmark yield curve to support the corporate bond market. While growing steadily in nominal terms, local currency government bonds outstanding have remained between $40 \%$ and $50 \%$ of GDP over the last decade, with local currency corporate bonds being relatively constant around 33\% of GDP (Figures A13, A14). Many of the large corporate issuers are government-related, but because the debt is not explicitly government-guaranteed they are classified as corporate issuers.

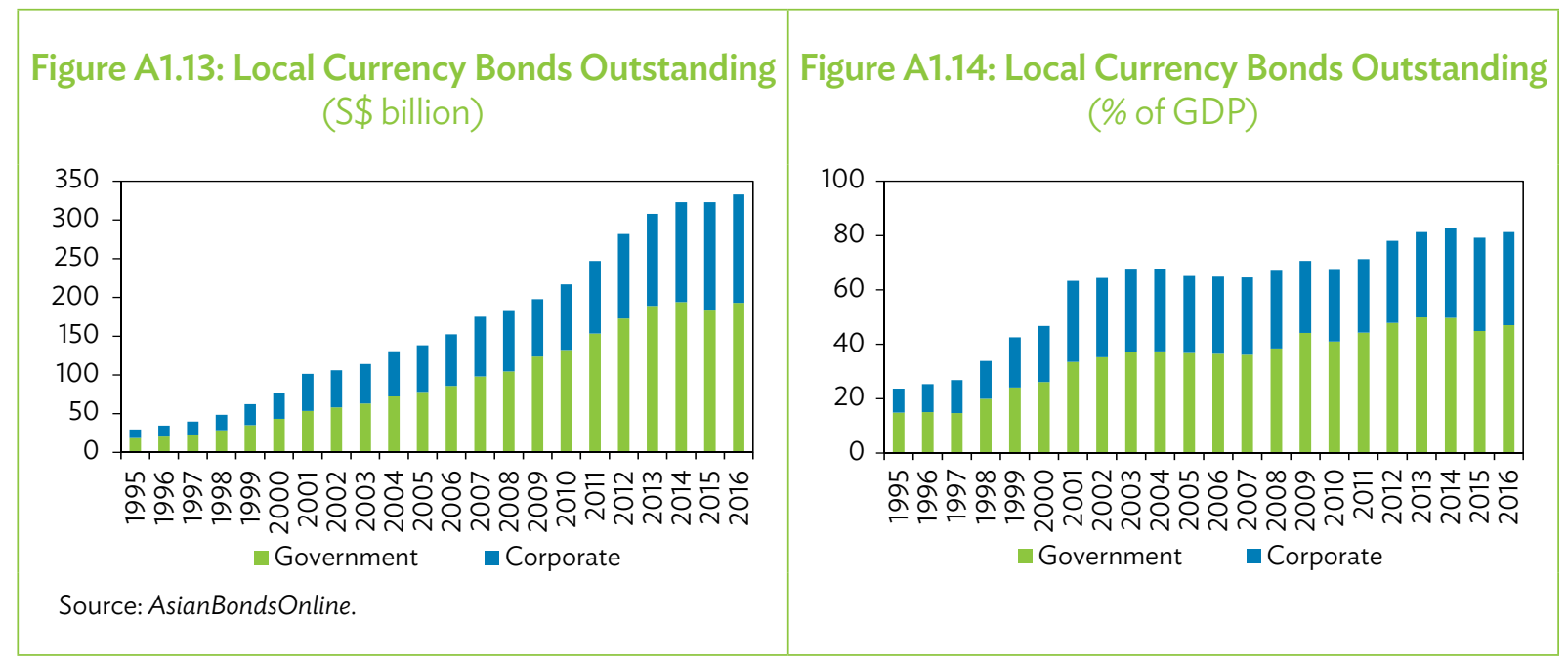




\section{Green Bonds}

There are two main drivers of the "push for green" in Singapore. One is coming from global nongovernment organizations, and to a lesser extent, investors in Europe and North America. Large corporates in the region are starting to feel the pressure, and hence have increasing interest in sustainability and potentially green financing. The Singapore Exchange has mandated sustainability reporting by listed companies on a comply or explain basis with effect from the end of 2017. This is expected to increase local emphasis on sustainability and green financing.

The second source of increasing interest in green financing comes from government policy initiatives to support commitments under the Paris Accord. Singapore has pledged to reduce its carbon emissions intensity by 36\% from 2005 levels by 2030 as well as stabilize its emissions with the aim of peaking around 2030. Green financing is seen as one means to achieve these objectives.

The MAS introduced in June 2017 a program that will provide a grant to offset the external review costs of a green bond issue up to $\$ \$ 100,000$. The MAS had concluded that there was no immediate yield advantage to green bond issues, so an incentive was likely required for most issuers to consider incurring the additional costs for a green bond. There is no established list of eligible external review providers, but the MAS could exclude firms if there are abuses of the program. Green issues may be in any currency as long as a Singapore-based underwriter is substantially involved in the issue. This potentially provides an incentive for Singapore to become a regional hub for green bond issues.

The grant program is part of larger national initiative on sustainable finance, essentially government asking the question what the financial sector is doing to contribute to national objectives. The Building and Construction Authority has established aggressive targets for greening the housing stock, which provides opportunities for green bond financing. The Association of Banks in Singapore has issued guidelines on responsible lending-banks need to incorporate sustainability into their credit decisions.

The first Singaporean green bond was issued in advance of the MAS grant program (Table A14). For corporate reasons, including a strong ESG commitment, City Developments Limited, a wholly owned subsidiary of CDL Properties, opted to issue a best-in-class green bond, using the CBI Standard, second opinion by Sustainalytics, and verification by KPMG. CDL operates in many countries and tangible evidence of its commitment to sustainability could contribute to good working relationships with regulatory authorities in many jurisdictions.

Proceeds of the green bond were used to repay a loan that had been advanced by the parent, CDL Properties, to City Developments Limited to retrofit Republic Plaza for energy efficiency and water conservation. These investments resulted in the saving of more than 6 million kilowatt-hours of energy annually and approximately 10,255 cubic meters of water.

A domestic bank was chosen as the underwriter due to its strong Singapore dollar capabilities even through CDL had been pitched by other banks with prior green bond 
experience. Pricing was flat relative to other $\mathrm{CDL}$ issues. As a well-known company, there would have been high demand for the bonds with or without a green label. The issue did not attract any new investors or any with specific SRI mandates, but was sold easily to domestic institutional investors.

The second Singaporean green bond was issued in July 2017 by DBS Group Holdings Limited, the parent of DBS Bank. This was a $\$ 500$ million tranche of its $\$ 30$ billion global medium-term note program. Proceeds will be used for the finance and treasury activities of DBS Group Holdings Limited, including the provision of intercompany loans or other forms of financing to DBS Bank and its subsidiaries. In turn, the funds will be used for the financing of green projects or assets in line with the DBS green framework. A second opinion was provided by Sustainalytics. The bonds were underwritten by a consortium of international banks and placed with a range of international investors.

\section{Table A1.14: Singapore Green Bond Issues}

\begin{tabular}{l|l|l|l}
\hline Issuer & \multicolumn{1}{|c|}{ Date } & \multicolumn{1}{c|}{ Currency and Size } & \multicolumn{1}{|c}{ Second Opinion } \\
\hline City Developments Limited & April 2017 & $\$ \$ 100$ million & $\begin{array}{l}\text { Sustainalytics, plus KPMG } \\
\text { verification }\end{array}$ \\
\hline DBS Group Holdings Ltd. & July 2017 & $\$ 500$ million & Sustainalytics \\
\hline
\end{tabular}

Sources: DBS, CDL, CBI data. https://www.climatebonds.net/cbi/pub/data/bonds (accessed 7 July 2017).

\section{Thailand}

Thailand's financial sector remains bank dominated, but mutual funds have grown rapidly to an amount equivalent to more than $25 \%$ of GDP, and contractual savings through life insurance and pension funds are collectively equivalent to about half of GDP (Table A15). Bank financing remains central for Thai corporates. Corporate bonds outstanding have increased steadily and, rather uniquely, a significant portion of the total is held by individual investors. Large Thai corporates have cultivated individual investors as an alternative financing source.

Prudential supervision is the responsibility of the Bank of Thailand with respect to deposittaking institutions and the Office of the Insurance Commission for life and general insurance companies. The primary legislation governing Thailand's capital markets is the Securities and Exchange Act, 1992 (as amended in 2008). The Ministry of Finance has ultimate responsibility for the regulation and oversight of Thailand's capital markets but delegates day-to-day responsibilities to a variety of entities. The Securities and Exchange Commission oversees corporate bond issuance and secondary trading, as well the activities of securities dealers and mutual fund and provident fund management companies. The Thailand Bond Market Association is an SRO established under the jurisdiction of the Securities and Exchange Commission, and is resposible for the development and operation of a fair and efficient bond market. The Public Debt Management Office is responsible for public debt management and the development of the government bond market. 
Table A1.15: Thailand Financial and Capital Markets Overview, 2016

\begin{tabular}{|c|c|c|c|c|}
\hline & Number & $\begin{array}{c}\text { Assets } \\
\text { (B billion) }\end{array}$ & $\begin{array}{l}\text { Assets } \\
\text { ( } \$ \text { billion) }\end{array}$ & $\begin{array}{c}\text { Assets } \\
(\% \text { of GDP) }\end{array}$ \\
\hline Banks & 30 & 17,721 & 502 & 123.4 \\
\hline Insurance companies & 61 & 3,360 & 95 & 23.4 \\
\hline Life insurance & & $2,895.77$ & 82 & 20.2 \\
\hline Non-Life insurance & & 465 & 13 & 3.2 \\
\hline Asset management companiesa & & 4,227 & 119 & 29.4 \\
\hline Thai Provident Fund & 1 & 1,015 & 28 & 7.1 \\
\hline Government Pension Fund & 1 & 771 & 22 & 5.4 \\
\hline Listed companies (market capitalization) & 522 & 15,079 & 427 & 105.0 \\
\hline Total debt securities outstanding & & 11,446 & 324 & 79.7 \\
\hline Of which, local currency & & 10,857 & 307 & 75.6 \\
\hline foreign currency & & 589 & 16 & 4.1 \\
\hline Government debt securities outstanding & & 8,022 & 227 & 55.9 \\
\hline Of which, local currency & & 7,938 & 224 & 55.3 \\
\hline foreign currency & & 84 & 2 & 0.6 \\
\hline Corporate debt securities outstanding & & 3,423 & 97 & 23.8 \\
\hline Of which, local currency & & 2,919 & 82 & 20.3 \\
\hline foreign currency & & 504 & 14 & 3.5 \\
\hline
\end{tabular}

a Including companies managing mutual funds.

Notes: $\$ 1$ = B35.3; GDP = B14,361 billion.

Sources: Bank of Thailand, Stock Exchange of Thailand, Government Pension Fund. Thai Provident Fund, AsianBondsOnline, CEIC Data.

\section{Local Currency Bond Markets}

Thai local currency bond markets have been growing both in nominal terms and relative to the GDP (Figures A15, A16). The corporate bond market remains thin, consisting of about 200 listed companies issuing bonds or notes, as well as government-related issuers and the private placement market. Banks have tended to lend aggressively to well-known names, lessening the attractiveness of bonds as a financing source.

The 2009 Capital Markets Masterplan identified more than 30 initiatives including a number specifically related to bond market development. This followed two earlier capital markets masterplans, which included measures to raise professional standards and practices, expand the investor base, clarify and modernize the regulatory structures, and improve the infrastructure supporting capital markets activities. With the supporting infrastructure now in place, the 2009 plan included a continued focus on increasing the quantity and variety of capital markets infrastructure as well as needed legislative reforms.

There has been limited progress to date on many of the initiatives of the 2009 Capital Markets Masterplan. ${ }^{15}$ Key achievements relate to increasing knowledge among market 


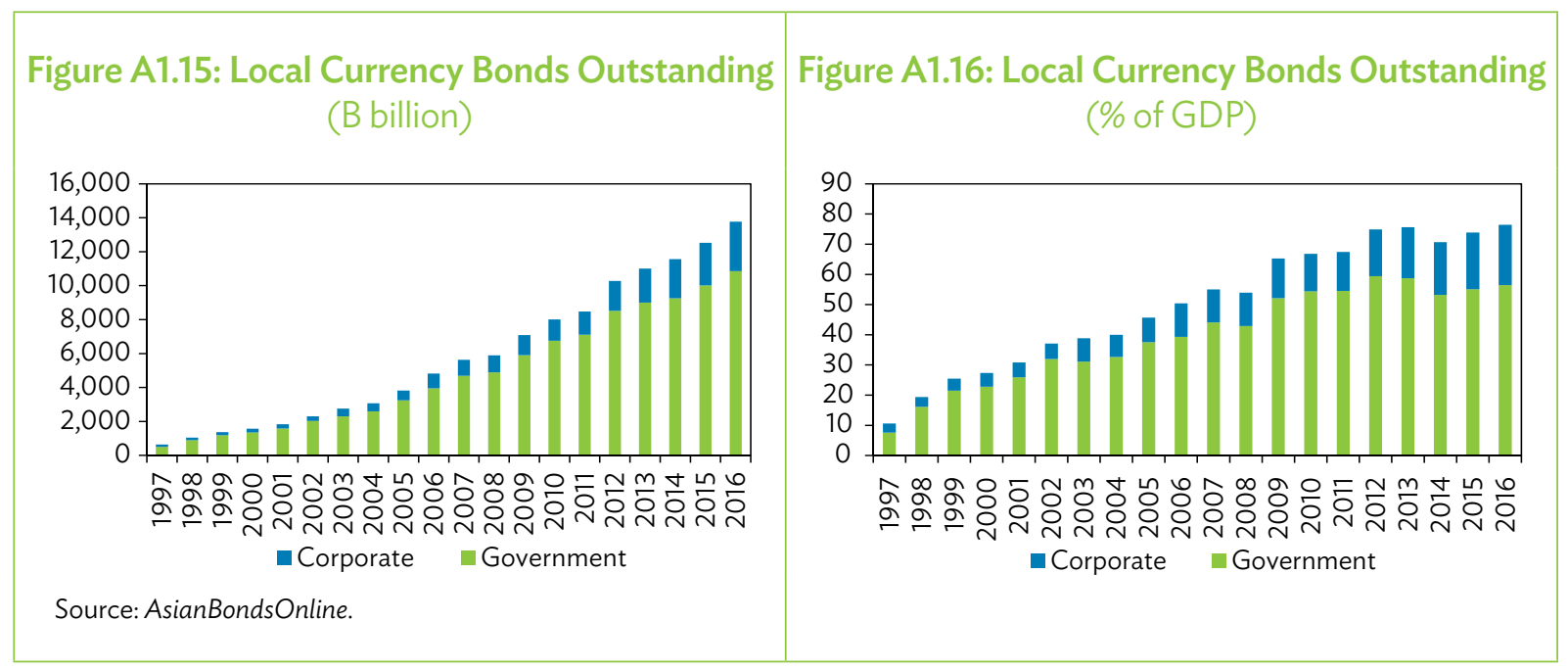

participants and the public at large. These include establishment in 2015 of the Securities and Exchange Commission's Capital Market Knowledge Center as a comprehensive source of financial and investment information for business enterprises and the public at large, and the 2010 creation of the Thailand Financial Instruments Information Center to collect information on financial instruments by related sources, share information, and provide linkages among related agencies.

\section{Green Bonds}

The Thai Ministry of Finance is one of the co-chairs of the ABMI Task Force on green bonds and is responsible for drafting policies to support green bonds in ASEAN. As such, it has begun to develop expertise in the area. Most market participants have limited awareness of or interest in ESG and green bonds. While market participants readily identify potential green projects, they are skeptical that the additional cost of green bond financing can be justified by the expected benefits. There is no regulatory framework for green bonds, but they can be readily accommodated under the existing capital markets laws and regulations.

Bangchak Corporation Public Company Limited issued a self-labeled B3 billion (\$92 million) green bond in 2015. Proceeds were used to invest in the company's 70\% owned subsidiary, BCPG, which is a Stock Exchange of Thailand listed vehicle for Bangchak's green energy business. The funds raised were used for solar, biomass, and geothermal energy projects in Thailand, Indonesia, and the Philippines. The bond did not have a second opinion and was criticized in the international community due to Bangchak's oil refining and fossil fuel businesses, despite the dedication of the funds raised to renewable energy. Bangchak has a long history of sustainability reporting and local market participants considered the issue green. The Bangchak bond was underwritten by the domestic subsidiary of an international bank. It was placed with a small number of domestic institutional investors and was priced flat relative to other Bangchak issues. 


\section{Viet Nam}

Viet Nam has a bank-dominated financial sector, although most of the other elements of developed financial and capital markets have been put in place (Table A15). Contractual savings institutions are small-life insurance penetration remains low with 17 small insurers having total assets equal to less than $3 \%$ of GDP. Most securities companies and funds management companies are quite small and many are affiliated with other financial institutions, primarily banks. The state Social Insurance Agency provides mandatory social insurance and retirement savings for employees in the formal sector, with total coverage of about 15\% of the workforce. It currently invests its surplus only in deposits at state-owned financial institutions.

\section{Table A1.16: Viet Nam Financial and Capital Markets Overview, 2016}

\begin{tabular}{|c|c|c|c|c|}
\hline & Number & $\begin{array}{l}\text { Assets } \\
\text { (D billion) }\end{array}$ & $\begin{array}{l}\text { Assets } \\
\text { (\$ billion) }\end{array}$ & $\begin{array}{l}\text { Assets } \\
(\% \text { of GDP) }\end{array}$ \\
\hline Credit institutions & & $8,632,210$ & 379.1 & 191.7 \\
\hline State-Owned banks & & $3,886,315$ & 170.6 & 86.3 \\
\hline Viet Nam Bank for Social Policies & & 160,414 & 7.0 & 3.6 \\
\hline Joint stock commercial banks & & $3,501,280$ & 153.7 & 77.8 \\
\hline $\begin{array}{l}\text { Joint venture, foreign-owned banks, and } \\
\text { branches }\end{array}$ & & 850,074 & 37.3 & 18.9 \\
\hline Finance and leasing companies & & 115,216 & 5.1 & 2.6 \\
\hline Cooperative bank & & 27,715 & 1.2 & 0.6 \\
\hline People's Credit Funds & & 91,196 & 4.0 & 2.0 \\
\hline Insurance & 46 & 193,158 & 8.5 & 4.3 \\
\hline Non-Life & 29 & 61,499 & 2.7 & 1.4 \\
\hline Life & 17 & 131,659 & 5.8 & 2.9 \\
\hline Listed companies, market capitalization & 696 & $1,647,217$ & 72.3 & 36.6 \\
\hline Ho Chi Minh Stock Exchange & 320 & $1,491,778$ & 65.5 & 33.1 \\
\hline Hanoi Stock Exchange & 376 & 155,439 & 6.8 & 3.5 \\
\hline Total debt securities outstanding & & $1,055,150$ & 46.3 & 23.4 \\
\hline Of which, local currency & & 995,721 & 43.7 & 22.1 \\
\hline foreign currency & & 59,429 & 2.6 & 1.3 \\
\hline Government debt securities outstanding & & $1,003,462$ & 44.1 & 22.3 \\
\hline Of which, local currency & & 949,725 & 41.7 & 21.1 \\
\hline foreign currency & & 53,737 & 2.3 & 1.2 \\
\hline Corporate debt securities outstanding & & 51,688 & 2.3 & 1.1 \\
\hline Of which, local currency & & 45,996 & 2.0 & 1.0 \\
\hline foreign currency & & 5,692 & 0.3 & 0.1 \\
\hline
\end{tabular}

Notes: $\$ 1$ = D22,770; GDP = D4,503,000 billion.

Sources: AsianBondsOnline, State Bank of Viet Nam, IMF Country Report No. 17/190 (July 2017), Ho Chi Minh Stock Exchange, Sustainable Stock Exchanges, Vietnamese Insurance Market Report (December 2016). 
There are two stock exchanges with a combined market capitalization of about $37 \%$ of GDP. The Hanoi Stock Exchange focuses on smaller company listings and also lists all government and some corporate bonds. The Ho Chi Minh Stock Exchange lists many of the larger companies and some corporate bonds. One of the major impetuses for growth of the capital markets has been the "equitization" of state-owned enterprises, with public listings of corporations in which government retains a significant ownership interest.

The State Securities Commission, established in 1996, is responsible for the development and oversight of capital markets. This includes regulation-making authority, licensing, surveillance and enforcement, and the training and licensing of industry practitioners. The Ho Chi Minh Stock Exchange and Hanoi Stock Exchange are SROs with authority over market participants. Insurance supervision falls under the Insurance Supervisory Authority of the Ministry of Finance. The State Bank of Vietnam is the prudential regulator for banks, which are the largest investors in bonds, and through their securities affiliates play a major role in broking, advising, and underwriting.

The Enterprise Law, 2005 provides the foundation for companies to issue various types of bonds as permitted by law and the entities' articles of incorporation. The Law on Securities, 2006 establishes the requirements for sale of securities to the public. In accordance with legal traditions in Viet Nam, further detail and elaboration on the law is provided in 37 decisions and decrees covering topics ranging from the functions and responsibilities of the SSC to requirements for bond issuance. SBV Decision 07/2008/QD-NHNN governs the issuance of debt by banks, which have been the largest issuers of bonds other than government and government-related entities.

The public offering requirements for bonds and equities are virtually identical. An issuer must submit to the SCC a dossier for registration including a prospectus and other prescribed documents. The SCC is required to approve, or reject with reasons, the public offering within 30 days of receipt of a complete dossier. The State Securities Commission review focuses on the completeness of the dossier and fulfillment of the prospectus and other requirements rather than the merits of the issue.

\section{Local Currency Bond Markets}

The bond markets in Viet Nam are dominated by government issues. There are about 50 corporate issuers with outstanding amounts equivalent to $1 \%$ of GDP. Private sector corporations first began to issue bonds in 2006. After strong growth in 2007 and the first half of 2008, corporate bond issuance was severely curtailed by the general dampening effect of the global financial crisis. Issuance rebounded in 2009 and 2010, however the fallout from the liquidity pressures in Viet Nam's banking sector effectively closed the corporate bond market in 2011 as banks, the largest purchasers of bonds, faced growing liquidity constraints. There has been a modest increase in corporate bond issues in 2015 and 2016, but Vietnamese corporates and state-owned enterprises overall remain reliant on bank financing.

Considerable further development of the local currency bond market will have to take place before it can play a significant role in Viet Nam corporate finance. The ongoing program of capital market development in Viet Nam has already identified most of the 
key initiatives required to expand the local currency bond markets. These relate to the framework for regulation and supervision and supporting infrastructure. In addition, developing domestic institutional investors-contractual savings, funds management, and the state Social Insurance Agency_can support capital market development by providing alternatives to banks as purchasers of corporate bonds. The local currency bond market will have to further develop before more specialized products such as project bonds and green bonds can emerge.

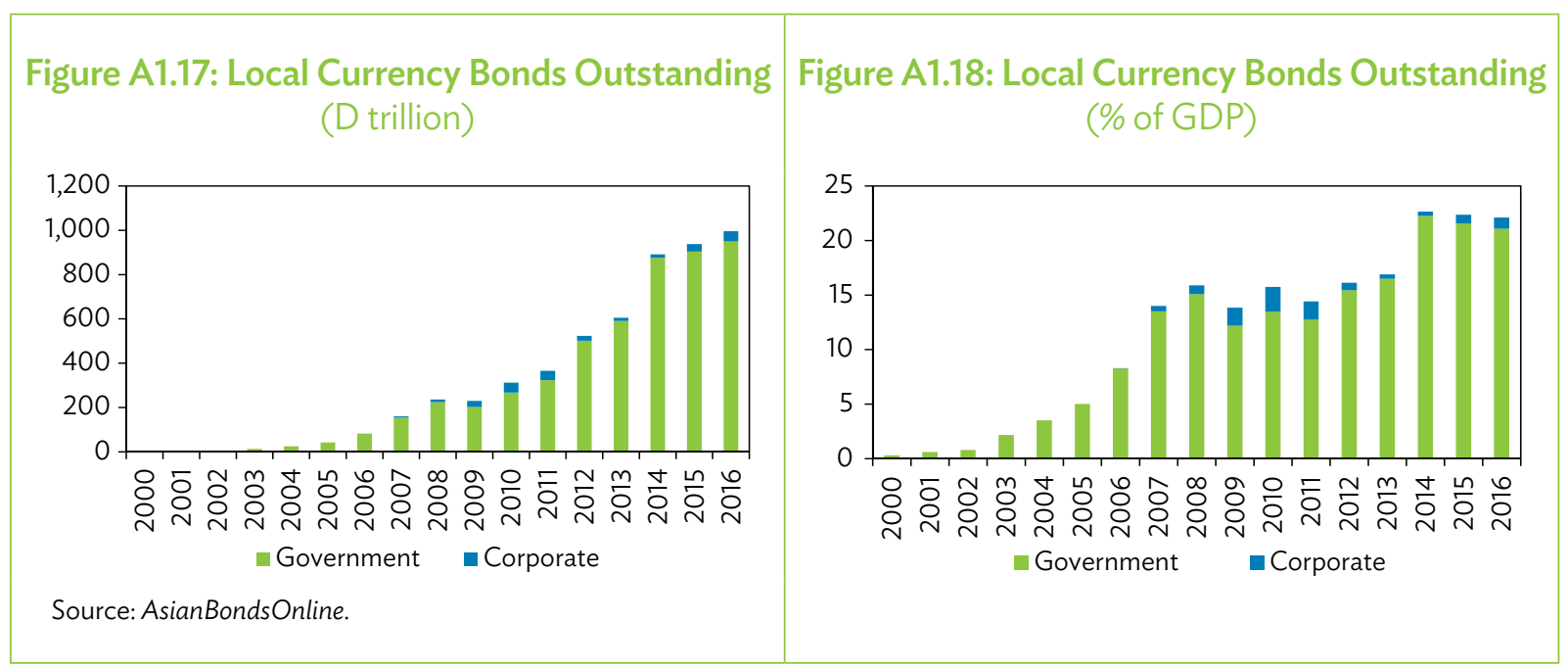




\section{Appendix 2: Profiles of Green Bond Funds}

\begin{tabular}{|c|c|c|c|}
\hline \multicolumn{4}{|c|}{$\begin{array}{l}\text { Name: Allianz Green Bond Fund } \\
\text { Investment Manager: Allianz Global Investors }\end{array}$} \\
\hline \multicolumn{4}{|c|}{$\begin{array}{l}\text { Benchmark: } 40 \% \text { BofA Merrill Lynch Euro Corp Index and 60\% BofA Merrill Lynch Green Bond } \\
\text { Indexed ( } € \text { hedged) }\end{array}$} \\
\hline Launched: & November 17, 2015 & $\%$ in Green Bonds: & $92 \%(\operatorname{Jan} 2017)$ \\
\hline Size: & $€ 64$ million (May 2017) & $\%$ in Em. Mrkts: ${ }^{*}$ & n.a. \\
\hline Currency: & $€$ & $\%$ in Asia:* & n.a. \\
\hline Fund Type: & SIVAC $^{* *}$ & No. of Holdings: & n.a. \\
\hline \multicolumn{4}{|c|}{ Asia holdings: Mitsubishi UFG, Bank of China } \\
\hline \multicolumn{4}{|c|}{$\begin{array}{l}\text { * Excludes multilateral development banks. } \\
\text { ** Société d'Investissement à Capital Variable, or open-ended investment company. }\end{array}$} \\
\hline \multicolumn{4}{|c|}{$\begin{array}{l}\text { Name: Amundi Green Bonds Fund } \\
\text { Investment Manager: Amundi Asset Management }\end{array}$} \\
\hline \multicolumn{4}{|c|}{ Benchmark: Bloomberg Barclays Green Bond Index ( $€$ hedged) } \\
\hline Launched: & December 21, 2015 & $\%$ in Green Bonds: & $85 \%$ \\
\hline Size: & $€ 26$ million (May 2017) & $\%$ in Em. Mrkts: ${ }^{*}$ & $3.2 \%$ \\
\hline Currency: & $€$ & $\%$ in Asia:* & $0 \%$ \\
\hline Type of Fund: & Mutual Fund (France) & No. of Holdings: & 17 \\
\hline \multicolumn{4}{|c|}{ Asia holdings: None } \\
\hline
\end{tabular}

* Excludes multilateral development banks. Fund holds 2.2\% in ADB bonds.

\begin{tabular}{|c|c|c|c|}
\hline \multicolumn{4}{|c|}{$\begin{array}{l}\text { Name: Amundi IFC Green Cornerstone Bond Fund } \\
\text { Investment Manager: Amundi }\end{array}$} \\
\hline \multicolumn{4}{|c|}{$\begin{array}{l}\text { Benchmark: n.a. Will invest in bank-issued green bonds in emerging markets. Aims to be fully } \\
\text { invested by } 2024\end{array}$} \\
\hline Launched: & April 2017 & $\%$ in Green Bonds: & $100 \%$ \\
\hline Size: & $\begin{array}{l}\$ 325 \text { committed, target is } \\
\$ 2 \text { billion }\end{array}$ & $\%$ in Em. Mrkts: & $100 \%$ \\
\hline Currency: & $\$$ & $\%$ in Asia:* & n.a. \\
\hline Type of Fund: & $\begin{array}{l}\text { Private fund for } \\
\text { institutional investors }\end{array}$ & No. of Holdings: & n.a. \\
\hline
\end{tabular}

* Excludes multilateral development banks. 


Name (Symbol): AXA World Funds Planet Bonds
Investment Manager: AXA Investment Managers
\begin{tabular}{l|c|c|c} 
Benchmark: None \\
\hline Launched: & September 22, 2015 & $\%$ in Green Bonds: & n.a. \\
\hline Size: & $€ 85$ million (May 2017) & $\%$ in Em. Mrkts: & $0.8 \%$ \\
\hline Currency: & $€$ & $\%$ in Asia:* & $2.7 \%$ \\
\hline Fund Type: & SICAV & No. of Holdings: & 84 \\
\hline
\end{tabular}

Asia holdings: Hyundai Capital Services (\$), Mitsubishi UFJ (\$), MTR Corp (\$), Bank of China (€), Ex-Im Bank of Korea (\$)

* Excludes multilateral development banks. Fund holds 3.2\% in ADB (\$).

** Société d'Investissement à Capital Variable, or open-ended investment company.

Name: Blackrock Green Bond Index Fund
Investment Manager: Blackrock Asset Management
\begin{tabular}{l|c|c|c}
\hline Benchmark: Bloomberg Barclays MSCl Green Bond Index (€ hedged) \\
\hline Launched: & January 17, 2017 & $\%$ in Green Bonds: & $\begin{array}{c}\text { "Predominantly" green } \\
\text { bonds }\end{array}$ \\
\hline Size: & $€ 23$ million (May 2017) & $\%$ in Em. Mrkts: & \\
\hline Currency: & $€$ & $\%$ in Asia:* & \\
\hline Fund Type: & UCITS $^{* *}$ & No. of Holdings: & \\
\hline Asia holdings: & & \\
\hline
\end{tabular}

* Excludes multilateral development banks.

** Undertaking for Collective Investment in Transferable Securities.

\begin{tabular}{|c|c|c|c|}
\hline \multicolumn{4}{|c|}{ Name: Calvert Green Bond Fund (CGAFX) } \\
\hline \multicolumn{4}{|c|}{ Benchmark: Bloomberg Barclays US Aggregate Bond Index } \\
\hline Launched: & October 31, 2013 & $\%$ in Green Bonds: & At least $80 \%$ \\
\hline Size: & $\$ 74$ million (March 2017) & $\%$ in Em. Mrkts: ${ }^{*}$ & $9.4 \%$ \\
\hline Currency: & $\$$ & $\%$ in Asia:* & $2.8 \%$ \\
\hline $\begin{array}{l}\text { Legal } \\
\text { Structure: }\end{array}$ & Mutual Fund & No. of Holdings: & 90 \\
\hline \multicolumn{4}{|c|}{$\begin{array}{l}\text { Asia holdings: Toyota Auto Receivables (\$), Mitsubishi UFJ (\$), Ex-Im Bank of Korea }(\$) \text {, Hyunda } \\
\text { Capital Services }(\$)\end{array}$} \\
\hline
\end{tabular}

* Excludes multilateral development banks. Fund holds $2.3 \%$ in ADB (\$). 


Name: HGA Obligations Vertes
Investment Manager: GA
\begin{tabular}{l|c|c|c} 
Benchmark: Barclays Aggregate $(€)$ \\
\hline Launched: & October 28,2015 & $\%$ in Green Bonds: & n.a. \\
\hline Size: & $€ 174$ million & $\%$ in Em. Mrkts: & n.a. \\
\hline Currency: & $€$ & $\%$ in Asia: & n.a. \\
\hline $\begin{array}{l}\text { Type of } \\
\text { Fund: }\end{array}$ & Mutual Fund (France) & No. of Holdings: & n.a. \\
\hline
\end{tabular}

Asia holdings: n.a.

* Excludes multilateral development banks.

\begin{tabular}{|c|c|c|c|}
\hline \multicolumn{4}{|c|}{$\begin{array}{l}\text { Name: Lyxor Green Bond UCITS ETF } \\
\text { Investment Manager: Lyxor International Asset Management }\end{array}$} \\
\hline \multicolumn{4}{|c|}{ Benchmark: Solactive Green Bond $€ \$ I G$ Index } \\
\hline Launched: & February 21, 2017 & $\%$ in Green Bonds: & $100 \%$ \\
\hline Size: & $€ 10$ million & $\%$ in Em. Mrkts: ${ }^{*}$ & About $10 \%$ \\
\hline Currency: & $€$ & $\%$ in Asia:* & About $5 \%$ \\
\hline Type of Fund: & $\mathrm{SICAV}^{* *}$ & No. of Holdings: & 23 \\
\hline
\end{tabular}

* Excludes multilateral development banks.

* Société d'Investissement à Capital Variable, or open-ended investment company.

Name: Mirova Green Bond - Global Fund
Investment Manager: Natixis Asset Management
\begin{tabular}{l|c|c|c}
\hline Benchmark: Bloomberg Barclays MSCl Green Bond Index (unofficial benchmark) \\
\hline Launched: & June 4, 2015 & $\%$ in Green Bonds: & Min 70\% \\
\hline Size: & $€ 149$ million (Feb 2017) & $\%$ in Em. Mrkts: & n.a. \\
\hline Currency: & $€$ & $\%$ in Asia: & $4.3 \%$ \\
\hline Fund Type: & SICAV & No. of Holdings: & 69 \\
\hline
\end{tabular}

Asia holdings: n.a.

* Excludes multilateral development banks. Fund holds 5.8\% in ADB (\$).

* Société d'Investissement à Capital Variable, or open-ended investment company. 


Name: Mirova Global Green Bond Fund (MGGAX)
Investment Manager: Naxitis Asset Management
\begin{tabular}{l|c|c|c} 
Benchmark: None \\
\hline Launched: & February 28,2017 & $\%$ in Green Bonds: & At least $80 \%$ \\
\hline Size: & $\$ 25$ million (March 2017) & $\%$ in Em. Mrkts: & $0 \%$ \\
\hline Currency: & $\$$ & $\%$ in Asia: & $0 \%$ \\
\hline Fund Type: & Mutual Fund & No. of Holdings: & 32 \\
\hline
\end{tabular}

Asia holdings: None.

* Excludes multilateral development banks.

\section{Name: NN Euro Green Bond Fund \\ Investment Manager: NN Investment Partners}

Benchmark: Bloomberg Barclays MSCI Euro Green Bond Index

\begin{tabular}{l|c|c|c} 
Launched: & March 1,2016 & \% in Green Bonds: & $100 \%$ \\
\hline Size: & $€ 94$ million & \% in Em. Mrkts: & $<10 \%$ \\
\hline Currency: & $€$ & $\%$ in Asia:* & About $2 \%$ \\
\hline Fund Type: & SICAV $^{* *}$ & No. of Holdings: & 60 \\
\hline Asia holdings: n.a.
\end{tabular}

* Excludes multilateral development banks.

Name: SMBC Nikki World Bank Green Bond Fund**
Investment Manager: Nikko Asset Management
\begin{tabular}{l|c|c|c} 
Benchmark: & None (only holds green bonds issued by the World Bank) \\
\hline Launched: & June 24, 2010 & $\%$ in Green Bonds: & $100 \%$ \\
\hline Size: & $¥ 6.5$ billion (May 2017) & $\%$ in Em. Mrkts: & $0 \%{ }^{* *}$ \\
\hline Currency: & $¥$ & $\%$ in Asia: & $0 \%$ \\
\hline Type of Fund: & Mutual Fund & No. of Holdings: & 20 \\
\hline Asia holdings: None** & & \\
\hline
\end{tabular}

* Excludes multilateral development banks.

** Holds some World Bank green bonds in emerging market and Asian currencies. 


Name: Nikki AM World Bank Green Bond Fund
Investment Manager: Nikki Asset Management
\begin{tabular}{l|c|c|c} 
Benchmark: None (only holds green bonds issued by the World Bank) \\
\hline Launched: & February 2010 & $\%$ in Green Bonds: & $100 \%$ \\
\hline Size: & $\$ 35$ million May 2017$)$ & $\%$ in Em. Mrkts: & $0 \%$ \\
\hline Currency: & $\$, £, €($ three classes) & $\%$ in Asia: & $0 \%$ \\
\hline Type of Fund: & SIVAC & No. of Holdings: & n.a. \\
\hline
\end{tabular}

Asia holdings: None**

* Excludes multilateral development banks.

** Holds some World Bank green bonds issued in emerging market and Asian currencies.

*** Société d'Investissement à Capital Variable, or open-ended investment company.

\begin{tabular}{|c|c|c|c|}
\hline $\begin{array}{l}\text { Name: Nikki A } \\
\text { Investment } M\end{array}$ & $\begin{array}{l}\text { M Shenton World Bank Gre } \\
\text { anager: Nikki Asset Manage }\end{array}$ & 3ond Fund & \\
\hline Benchmark: $\mathrm{N}$ & one (only holds green bonds & ed by the World Banl & \\
\hline Launched: & 2010 & \% in Green Bonds: & $100 \%$ \\
\hline Size: & S\$14 million (April 2017) & $\%$ in Em. Mrkts: ${ }^{*}$ & $0 \% * *$ \\
\hline Currency: & $S \$$ & $\%$ in Asia:* & $0 \%$ \\
\hline Type of Fund: & SIVAC ${ }^{* * *}$ & No. of Holdings: & n.a. \\
\hline Asia holdings: & None** & & \\
\hline
\end{tabular}

\begin{tabular}{l} 
Name: Raiffeisen Green Bonds Fund \\
Investment Manager: Raiffeisen Asset Management \\
\begin{tabular}{l|c|c|c} 
Benchmark: BAML Green Bond Index \\
\hline Launched: & September 15, 2015 & $\%$ in Green Bonds: & n.a. \\
\hline Size: & $€ 50$ million (May 2017) & $\%$ in Em. Mrkts:* & n.a. \\
\hline Currency: & $€$ & $\%$ in Asia:* & n.a. \\
\hline Type of Fund: & Mutual Fund (Austria) & No. of Holdings: & n.a. \\
\hline Asia holdings: & & &
\end{tabular} \\
\hline
\end{tabular}

Asia holdings: n.a.

* Excludes multilateral development banks. 


Name: SEB Green Bond Fund
Investment Manager: SEB Investment Management
\begin{tabular}{l|c|c|c} 
Benchmark: n.a. & \% in Green Bonds: & At least $70 \%$ \\
\hline Launched: & April 2015 & $\%$ in Em. Mrkts: & $3.4 \%$ \\
\hline Size: & $€ 99$ million (May 2017) & $\%$ in Asia: & $2.6 \%$ \\
\hline Currency: & $€$ & No. of Holdings: & 74 \\
\hline Type of Fund: & UCITS** &
\end{tabular}

Asia holdings: Agricultural Bank of China, Development Bank of Japan

ADB holdings: $1.87 \%$

* Excludes multilateral development banks.

** Undertaking for Collective Investment in Transferable Securities.

Name: State Street Global Green Bond Index Fund
Investment Manager: State Street Global Advisors
\begin{tabular}{l|c|c|c} 
Benchmark: Bloomberg Barclays MSCl Green Bond Index \\
\hline Launched: & May 5, 2017 & $\%$ in Green Bonds: & n.a. \\
\hline Size: & n.a. & $\%$ in Em. Mrkts: & n.a. \\
\hline Currency: & $€$ & $\%$ in Asia: & n.a. \\
\hline Type of Fund: & SICAV** & No. of Holdings: & n.a. \\
\hline
\end{tabular}

Asia holdings: n.a.

* Excludes multilateral development banks.

** Société d'Investissement à Capital Variable, or open-ended investment company.

Name: VanEck Vectors Green Bond ETF
Investment Manager: VanEck
\begin{tabular}{l|c|c|c}
\hline Benchmark: S\&P Green Bond Select Index \\
\hline Launched: & March 3, 2017 & $\%$ in Green Bonds: & $100 \%$ \\
\hline Size: & $\$ 8$ million (July 2017) & $\%$ in Em. Mrkts: & $10.2 \%$ \\
\hline Currency: & $\$$ & $\%$ in Asia: & $7.6 \%$ \\
\hline Type of Fund: & ETF & No. of Holdings: & 41 \\
\hline
\end{tabular}

Asia holdings: Bank of China, MTR Corp, Export-Import Bank of Korea, ADB

ADB holdings: $1.25 \%$

* Excludes multilateral development banks. All emerging market holdings are in dollars or euros. 


\section{Promoting Green Local Currency Bonds for Infrastructure Development in ASEAN+3}

The Asian Development Bank and the Association of Southeast Asian Nations and the People's Republic of China, Japan, and the Republic of Korea (ASEAN+3) are looking to explore options to promote green local currency-denominated bonds to meet the region's infrastructure development needs. Green bonds-supported within the ASEAN+3 framework-would help meet the long-term financing of the region especially in its transition to a low-carbon region. This publication highlights an assessment study of green bond markets in ASEAN+3, identifies the barriers to green bond market development, and proposes recommendations to scale up green bond markets for infrastructure development in ASEAN+3.

\section{About the Asian Development Bank}

ADB's vision is an Asia and Pacific region free of poverty. Its mission is to help its developing member countries reduce poverty and improve the quality of life of their people. Despite the region's many successes, it remains home to a large share of the world's poor. ADB is committed to reducing poverty through inclusive economic growth, environmentally sustainable growth, and regional integration.

Based in Manila, ADB is owned by 67 members, including 48 from the region. Its main instruments for helping its developing member countries are policy dialogue, loans, equity investments, guarantees, grants, and technical assistance. 